

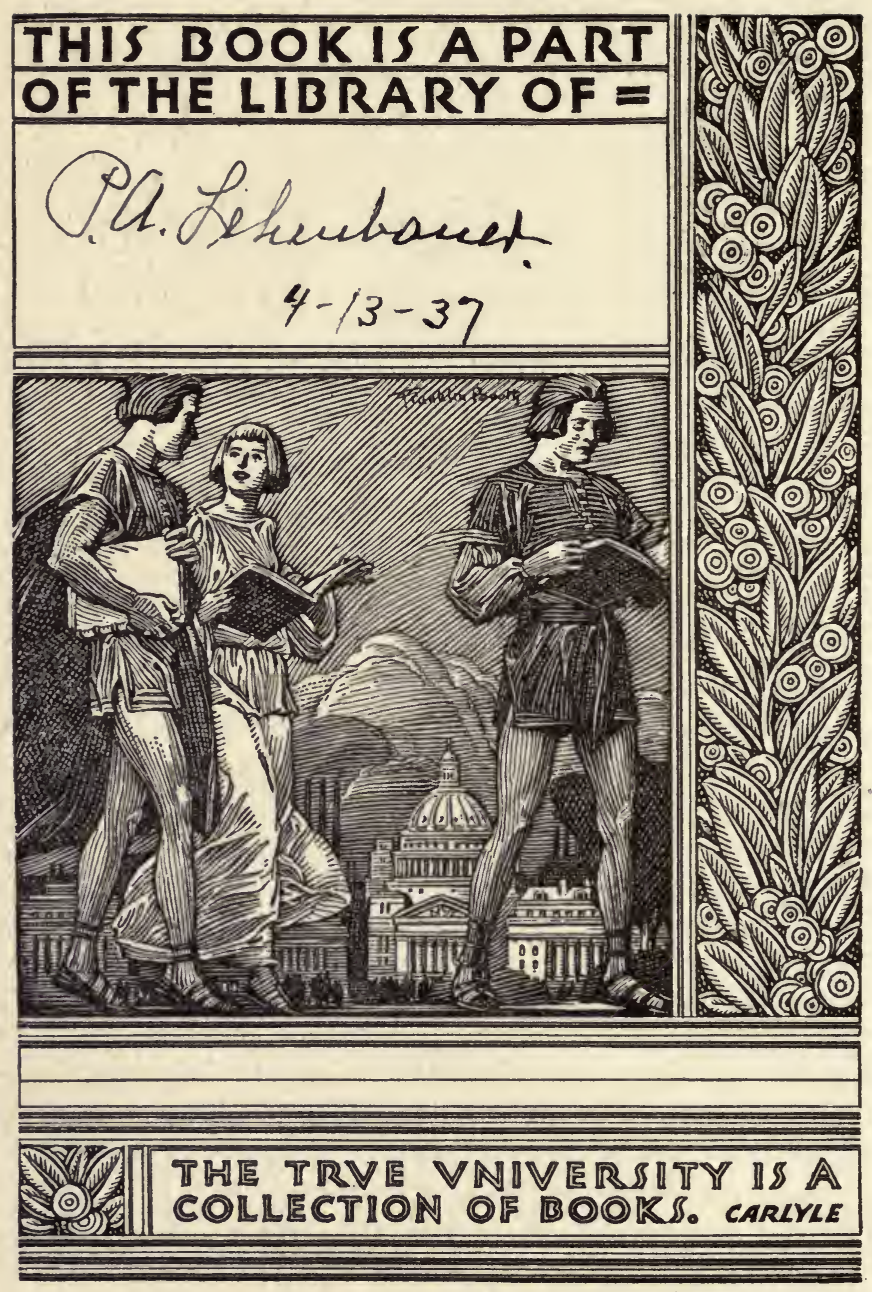
List Price $\$ 3.25$

From the collection of the

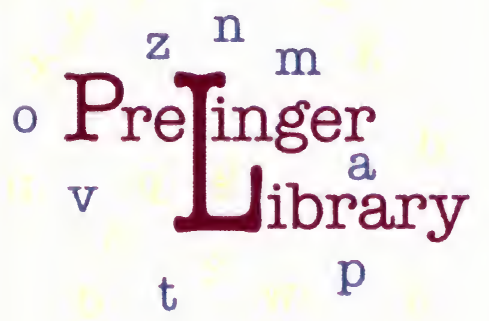

San Francisco, California 2006 


\section{WORKS OF NELSON COURTLANDT BROWN}

JOHN WILEY \& SONS, Inc.

A General Introduction to Forestry in the United States, with special reference to recent forest conservation policies

293 pages. 137 figures. 6 by 9 . Cloth.

Logging-Principles and Practices in the United States and Canada

284 pages. 153 figures. 6 by 9 . Cloth.

Logging-Transportation

327 pages. 167 figures. 6 by 9 . Cloth.

The American Lumber Industry

279 pages. 39 figures. 6 by 9 . Cloth.

Forest Products: Their Manufacture and Use

Second Edition, Revised. 447 pages. 120 figures.

6 by 9 . Cloth.

By the Late F. MOON AND N. C. BROWN

Elements of Forestry

Second Edition. 409 pages. 71 figures. $5 \frac{1}{4}$ by 8 .

Cloth. 



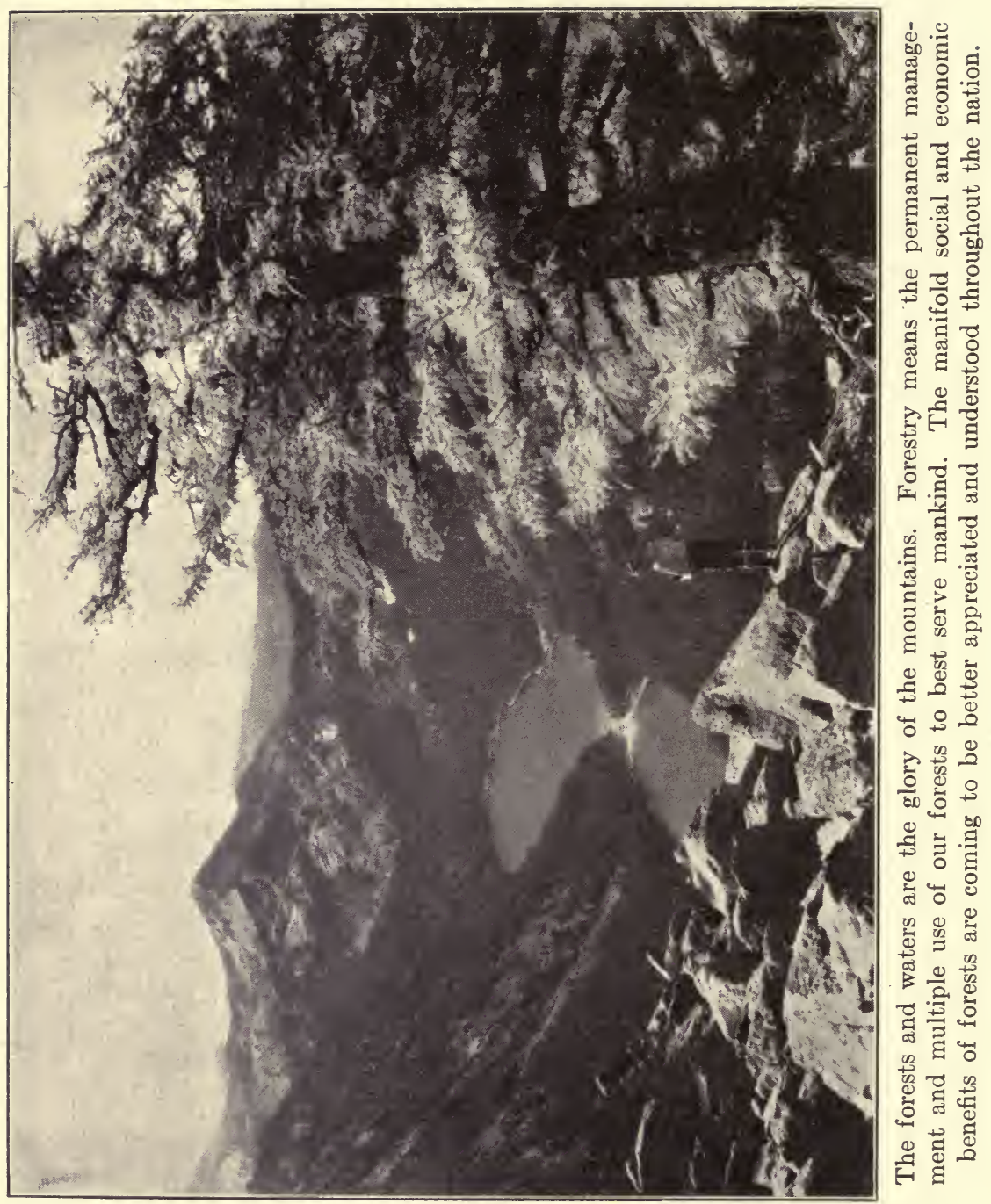




\title{
A GENERAL INTRODUCTION
}

TO

\section{FORESTRY IN THE UNITED STATES}

WITH SPECIAL REFERENCE TO

RECENT FOREST CONSERVATION POLICIES

\author{
BY \\ NELSON COURTLANDT BROWN \\ Professor of Forest Utilization, The New York State College \\ of Forestry at Syracuse University
}

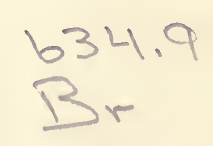

NEW YORK

J OH N W I L E Y \& S N S, INC.

LONDON: CHAPMAN \& HALL, Limited 
Copyright, 1935,

BY

\section{Nelson Courtlandt Brown}

All Rights Reserved

This book or any part thereof must not be reproduced in any form without the written permission of the publisher. 
To

\section{FRANKLIN DELANO ROOSEVELT}

This volume is respectfully and affectionately dedicated. The only American to receive the Sir William Schlich medal for meritorious services in forestry, he is distinguished for his contributions in advancing the cause of forest conservation by governmental enactments. Through his farseeing vision, able and unswerving guidance and unsurpassed leadership, forestry has emerged to a place

of general understanding, recognition, and appreciation by the American people. 



\section{FOREWORD}

The American people have enjoyed the use and benefit of sufficient primary natural resources to develop this nation to a position of great strength and prosperity. If our people will learn how to use, manage, and maintain them for the widest present and permanent benefits and to apply this knowledge gained by experience through the coming years, it is likely that our natural resources may continue to contribute in very substantial fashion to further strength, prosperity, and happiness.

Our forests, next to our soils, are our most precious natural resource. Around this vast resource, occupying approximately onefourth of our total land surface, is built a new concept of national planning. The work to be accomplished is conservation, management, and enhanced use, and this is a challenge not for the next few years but for many generations to come. Our rich and varied forests are capable of supplying our domestic requirements and a very extensive and profitable export trade that should inure to the benefit and prosperity of our people. It is of great importance that due consideration be given to the conservation of our forest resources. This work is intimately integrated with other primary resources, chiefly soil, water, and mineral.

It is significant that, within the past few years, a new appreciation and understanding of the contributions which our natural resources may make to the prosperity of the nation have developed. Through recent government emergency measures, conservation has enjoyed most noteworthy forward progress.

It is hoped that this general treatise on the subject of forestry may contribute to a better understanding and appreciation of the part our forests may play in the welfare and happiness of the American nation.

Nelson Courtlandt Brown.

Syracuse, New York

September, 1935 



\section{ACKNOWLEDGMENT}

The author wishes to express his appreciation to the U. S. Forest Service and the National Park Service, and to individual members of these organizations, for material and especially for their excellent spirit of cooperation and assistance. $\mathrm{He}$ is indeed grateful to the Forest Service for data on forest resources and other information as found in several publications, notably in the Copeland Report, Senate Document No. 12, 1933, and for the photographs shown as: frontispiece, and Figs. 3 to 7 inclusive, 14, 16, 20, 21, 23, 24, 26, 27, 29 to 51 inclusive, 53 to 57 inclusive, $59,60,62,67$ to 70 inclusive, 72 to 74 inclusive, 77, 82 to 86 inclusive, 93, 96 to 109 inclusive, 116, 117, 119, $120,122,123,128$ to 135 inclusive, 137 to 139 inclusive; and to the National Park Service for Figs. 110 to 115 inclusive.

The author is also indebted to a number of lumber manufacturers, state foresters, loggers, forest rangers, and others for valuable data and information secured on several visits to the National Forests, National Parks, and private operations in the Rocky Mountains, the Pacific Coast States, the South, and the Lake States. Many data were also obtained on visits to more than a hundred Civilian Conservation Corps Camps in the western states as well as to several in the southern Appalachian region and in the Northeast, and studies on the ground of the Tennessee Valley Authority, Plains Shelterbelt Project, and the Soil Conservation Service. To several colleagues of the faculty of the New York State College of Forestry I am indebted for valuable suggestions, assistance, and criticisms. 



\section{ABBREVIATIONS}

For brevity in the case of reiterated and frequently occurring expressions, the following are generally used:

Thousand board feet ...................

Board feet .............................

(one board foot $=$ a piece $1^{\prime \prime} \times 12^{\prime \prime} \times 12^{\prime \prime}$ )

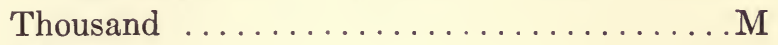

Inches ........................"

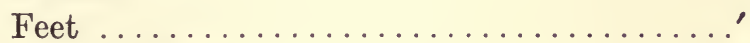

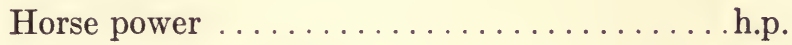

Diameter breast high ....................

( $4 \frac{1}{2}$ feet above ground)

Free on board ........................

Per centum $\ldots \ldots \ldots \ldots \ldots \ldots \ldots$ 



\title{
CONTENTS
}

\author{
PART I \\ HISTORY, ECONOMICS, AND IMPORTANCE
}

CHAPTER

PAGE

I. INtroduction . . . . . . . . . . . . . . . . . 1

1. Definition; social and economic implications . . . . . 1

2. Why forestry is needed-summary of objectives . . . . 9

3. European methods changed to fit American conditions . . 14

4. Forestry as a profession . . . . . . . . . . . . 16

5. Principal branches of forestry . . . . . . . . . 22

6. Arboriculture and forestry . . . . . . . . . . . 24

II. History and Development . . . . . . . . . . . 26

1. Early beginnings . . . . . . . . . . . . . . 26

Arbor Day and its influence . . . . . . . . . . . . . 26

2. The pioneering and nomadic lumber industry . . . . . 27

3. Passing of the last resource frontiers . . . . . . . . . 29

4. Federal activities and legislation to promote forest conservation . . . . . . . . . . . . . . . 30

5. Leaders in the development of American forestry . . . . 32

III. Forest Resources; Principal Trees and Regions . . . . . 34

1. General-forest regions . . . . . . . . . . . . 34

1. Eastern forest regions . . . . . . . . . . . 34

2. Western forest regions . . . . . . . . . 35

2. Areas . . . . . . . . . . . . . . . . . 38

3. Ownership . . . . . . . . . . . . . . . . 39

4. Volume of standing timber . . . . . . . . . . . 40

5. Leading commercial species . . . . . . . . . . . 42

1. Western softwoods . . . . . . . . . . 43

2. Eastern softwoods . . . . . . . . . . . 47

3. Eastern hardwoods . . . . . . . . . . . 48

6. Principal products of the forest; growth and depletion . . 50

PART II

FORESTRY TECHNIQUE AND MEASURES TO ACCOMPLISH A RATIONAL POLICY OF FOREST MANAGEMENT

IV. The Tree and Its Characteristics . . . . . . . . . . 53

1. Definition . . . . . . . . . . . . . . 53

2. How a tree functions . . . . . . . . . . . 54 
3. Characteristics of tree growth . . . . . . . . . . 55

4. Varieties of trees . . . . . . . . . . . . . 56

5. How trees grow and reproduce . . . . . . . . . . 57

V. Forest Influences . . . . . . . . . . . . . . . 61

1. The forest as a community of trees . . . . . . . . 61

2. Silvics or forest ecology . . . . . . . . . . . . . 61

3. Influence of forest on its environment . . . . . . . 62

1. Climate . . . . . . . . . . . . 62

2. Soil . . . . . . . . . . . . . 62

4. Forest types and their characteristics . . . . . . . . 63

5. Pure and mixed forests . . . . . . . . . . . 65

6. Factors determining the selection of species . . . . . . 66

Vi. Forest Protection . . . . . . . . . . . . . . . 67

1. General . . . . . . . . . . . . . . 67

2. Forest fires-importance and extent . . . . . . . 68

3. Causes of forest fires . . . . . . . . . . . 73

4. Methods of detection . . . . . . . . . . . 74

5. Methods of prevention . . . . . . . . . . . . 75

6. Methods of control and suppression . . . . . . . . 80

7. Southern forest fire problem . . . . . . . . . . . 82

8. Forest insects . . . . . . . . . . . . . . . 83

9. Forest fungi . . . . . . . . . . . . . . . 85

10. Domestic animals . . . . . . . . . . . . . . 88

11. Wild animals . . . . . . . . . . . . . . . . 88

12. Sand dunes and miscellaneous . . . . . . . . . . . . 89

Vil. Forest Mensuration . . . . . . . . . . . . . . 91

1. General . . . . . . . . . . . . . . . 91

2. Units of measure . . . . . . . . . . . . . . 91

3. Instruments commonly used . . . . . . . . . . 92

4. Log rules . . . . . . . . . . . . . . . . . . . 93

5. Scaling . . . . . . . . . . . . . . . . . . 93

6. Volume tables . . . . . . . . . . . . . . . 94

7. Cruising . . . . . . . . . . . . . . . . 94

8. Yield tables . . . . . . . . . . . . . . . . . . 95

9. Stumpage and stumpage appraisal . . . . . . . . . 96

VIII. Silviculture-Methods of Natural Reproduction . . . . . 99

1. Definitions and general considerations . . . . . . . 99

2. Advantages of natural versus artificial reproduction . . 100

3. Silvicultural systems . . . . . . . . . . . . 101

4. American versus European silvicultural systems . . . . 106

5. Silvicultural systems of cutting some representative types in the National Forests . . . . . . . . . . . 107

IX. Silviculture-Methods of Artificial Reproduction (Reforestation or Tree Planting

2. Conditions requiring tree planting . . . . . . . . 116 
3. Seed selection . . . . . . . . . . . . . . . 117

4. Methods of seed collection . . . . . . . . . . . 117

5. Nursery practice-seed and transplant beds . . . . . . 118

6. When to plant . . . . . . . . . . . . . . . 120

7. How and what to plant . . . . . . . . . . . . 121

8. Use of wild stock in planting . . . . . . . . . . . 127

X. Silvicultural Treatment of Young and Immature Stands (Intermediate Cuttings) . . . . . . . . . . . . . . 128

1. General . . . . . . . . . . . . 128

2. Economic considerations . . . . . . . . . . . 129

3. Silvicultural systems of treatment . . . . . . . . . 131

4. General rules for thinning . . . . . . . . . . . 133

XI. Forest Utilization-Industrial Forestry . . . . . . . . 135

1. General-importance of lumber and associated industries . 135

2. Advantages of wood construction . . . . . . . . . 138

3. Logging methods and procedure . . . . . . . . . 139

4. Selective logging . . . . . . . . . . . . . . 147

5. Manufacture and conditioning . . . . . . . . . . 152

Principal species of lumber and producing states . . . 154

6. Costs of producing lumber . . . . . . . . . . . . 155

7. Lumber distribution . . . . . . . . . . . . . 156

XII. Forest Utilization-Wood Uses and Economics . . . . . . 159

1. Properties and their relation to uses of wood . . . . . 159

2. Principal sources of waste in the forest and at manufacturing plants . . . . . . . . . . . . . . 164

3. Economic conditions determining degree of utilization . 166

4. Industrial forest policies . . . . . . . . . . . . 167

5. Developments in reducing woods and sawmill waste . . . 169

6. Forest products . . . . . . . . . . . . . . 172

1. General . . . . . . . . . 172

2. Cross ties, poles, piling, and mine timbers . . . . 174

3. Wood pulp and paper-rayon and fiber boards . . . 175

4. Fuelwood . . . . . . . . . . . . . 177

5. Veneers and plywood . . . . . . . . . . 178

6. Naval stores . . . . . . . . . . . . . . 179

7. Cooperage ... . . . . . . . . . . . . 181

8. Tanning materials and dyewoods . . . . . . . 181

9. Wood distillation . . . . . . . . . . . . 181

10. Maple syrup and sugar . . . . . . . . . . . 182

11. Rubber . . . . . . . . . . . . . . . 183

7. Trends toward stability of location, employment, and output 183

XIII. Forest Utilization-Timber Preservation . . . . . . . 185

1. History and importance . . . . . . . . . . . . 185

2. Materials treated . . . . . . . . . . . . . . 185

3. Requirements of good preservative . . . . . . . . 186

4. Principal methods of preservation . . . . . . . 186 
PART III

ORGANIZATIONS AND AGENCIES TO ACCOMPLISH A RATIONAL FOREST POLICY

CHAPTER

PAGE

XIV. The Forest Service and the National Forests . . . . . . 190

1. History and development . . . . . . . . . . 190

2. Extent and location of National Forests . . . . . . 193

3. Organization of the Forest Service . . . . . . . . 193

4. Organizatoin and work of a National Forest . . . . . 202

5. National Forests as models of forestry practice . . . . . 204

XV. The National Park Service and National Parks . . . . 205

1. History and development . . . . . . . . . . 205

2. Purposes and functions as distinct from National Forests . 208

3. Location, size, and features of the National Parks . . . 210

XVI. State Forests and Forest Policies . . . . . . . . . . 213

1. History . . . . . . . . . . . . . . . . 213

2. Number and character of state forest organizations . . . 214

3. Functions and activities . . . . . . . . . . . 214

4. Trends and policies . . . . . . . . . . . . 217

XVII. County, Town, And Community Forests . . . . . . . . 219

1. General . . . . . . . . . . . . . 219

XVIII. Private Forestry . . . . . . . . . . . . . . . . 221

1. Relative importance . . . . . . . . . . . . . 221

2. Past history and trends-what has been accomplished . . 221

3. The farm woodland and the small timber tracts . . . . 223

4. Principal difficulties and deterrents to the practice of private forestry . . . . . . . . . . . . . . 225

\section{PART IV}

\section{EDUCATION AND RESEARCH}

XIX. Forestry Education in the United States . . . . . . 228

1. Schools of forestry . . . . . . . . . . . . . 228

2. What forestry graduates do . . . . . . . . . . 230

XX. Forest Research . . . . . . . . . . . . . . 232

1. General . . . . . . . . . . . . . . 232

2. Principal activities . . . . . . . . . . . . 234 


\section{PART V}

FORESTRY IN THE NEW GOVERNMENTAL PROGRAMS CHAPTER

XXI. General

1. Enlarged National Forest acquisition program . . . . . 239

XXII. Emergency Conservation Work (Civilian Conservation Corps) 241

XXIII. The Tennessee Valley Authority . . . . . . . . . . 249

XXIV. The Soll Conservation Service . . . . . . . . . . . 255

XXV. The Plains Shelterbelt Project . . . . . . . . . . 263

XXVi. The Public Domain Grazing Administration (Division of GrazING Control) . . . . . . . . . . . . . . . . . 272

XXVII. Forestry, Land Use, and National Planning . . . . . . 275

\section{APPENDIX}

Bibliography . . . . . . . . . . . . . . . . . . . . 281

The National Industrial Recovery Act, the Lumber Code and Forestry 284

Common and Botanical Names of Trees . . . . . . . . . . . 288

INDEX . . . . . . . . . . . . . . . . . . . . 291 



\title{
GENERAL FORESTRY
}

\author{
PART I \\ HISTORY, ECONOMICS, AND IMPORTANCE
}

\section{CHAPTER I}

\section{INTRODUCTION}

\section{DEFINITION; SOCIAL AND ECONOMIC IMPLICATIONS}

Forests have always played an important part in the economic structure of our nation. They may be used for the continued economic and social betterment of the people. Forestry may be briefly defined as the best use of the forest. It is the art and science of managing our forests and converting the product to best serve mankind. Continuity of production and use is the central theme. Heretofore, our forests, during the colonial and expansion periods of westward development, have been viewed largely as a resource to be exploited. Little thought was given to the future of our natural resources. Forests served as a deterrent rather than as an aid to civilization during the early generations. Now, sustained yield management, treating the forests as a source of periodic crops, has replaced the former practice of exploitation and wastage. Thus, forestry deals with the growing and use of successive crops of timber. Perpetuation and continuous productivity of the forests to serve the manifold social and economic benefits of our people have become recognized as one of the most important aspects of our internal development.

Forestry has also been defined as the growing and use of successive crops of timber on lands unsuited to agriculture. Forestry is sometimes described as a part of agriculture. It is really a separate and distinct subject, however. It is closely allied to agriculture and provides a soil crop. But forestry is also closely integrated with engineering, transportation, chemistry, and the broad field of business and economics. Forestry is planned economy for the best management and utilization of our forests and forest lands, which include approxi- 
mately five hundred million acres* of land surface, or about onefourth of the total area of the United States. Borne on a crusading wave of enthusiasm to prevent a possible timber famine, forestry has been extended to include within its concept not only the production

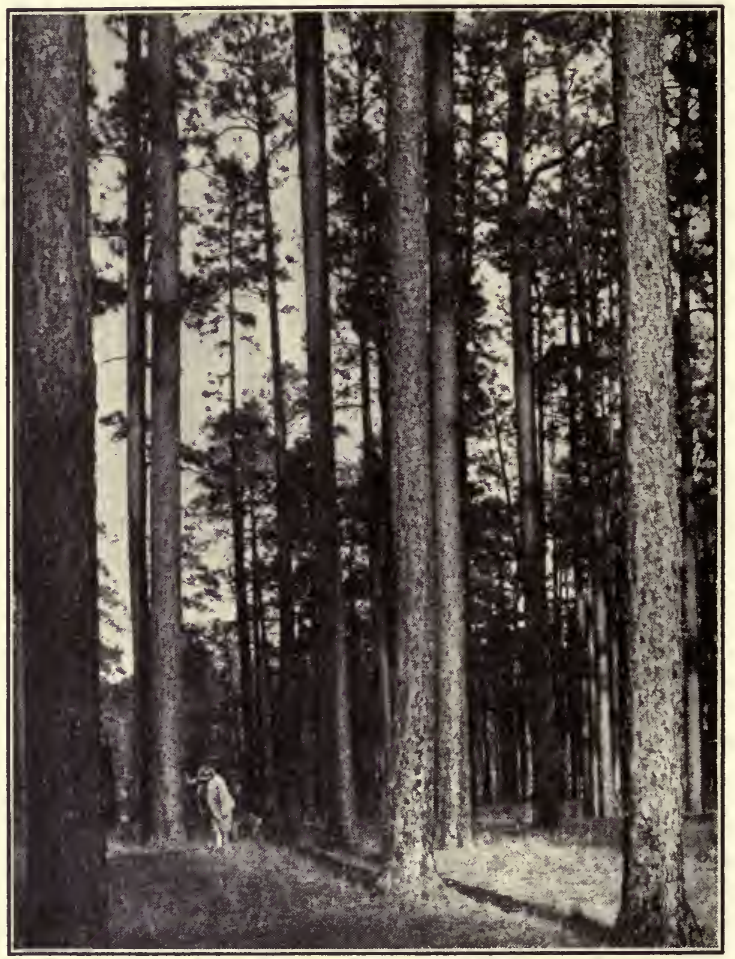

FIG. 1.-A typical stand of virgin longleaf and shortleaf pine in the South. The South contains about $39 \%$ of all the commercial forest area of the country. This is largely southern pine composed of four species (longleaf, shortleaf, loblolly and slash pines). Because of the large areas available in 11 southern and southeastern States, the long, warm growing season, with abundant precipitation and rapid growth, proximity to important domestic and export markets, and the increased areas available for timber growing, this region will probably be the most important one for the growth of lumber and other forest products in the future.

of timber to meet our material requirements of construction, fuel, and allied objectives, but also the much broader and socially related fields of achievement. For example, the desired objectives under some conditions may be provision for the finest type of recreational facilities;

* Including commercial and non-commercial forests as well as potential forests, the total area is about six hundred million acres. 
the propagation of bird, fish, and animal life for recreation through hunting and fishing; the prevention of erosion to protect both forest and agricultural soils; the control of water flows for power, irrigation, or potable purposes, or perhaps for scenic and aesthetic enjoyment. In each region of the country, the particular kind of forestry practiced must lend itself to the local requirements. Population growth and trends, the excellent systems of highways, the need for health and camping facilities in the woods, and the demand for water for reclamation purposes are factors to be considered. Thus, multiple-purpose forestry has replaced the former narrow concept of a single objective - that of wood production.

The automobile and improved highways have vitally changed our national habits. In contrast to the thousands of a decade ago, millions are now seeking recreation, health, and enjoyment in the forests. National planning for land use is crystallizing largely around forest areas and forest problems. With surplus agricultural crop production, the reversion to forest of many areas formerly tilled, the decreasing per capita consumption of lumber to less than one-half that of 1911, and with better fire protection and improved growing conditions, it seems likely that we may be able to grow sufficient timber to meet our future requirements. This is probable in spite of increasing population. The fear of a timber famine does not seem justified, and as forestry was developed in Europe because of a threatened fuel famine, so it is likely that the objectives and definitions of forestry may change through the years. During the brief space of the past thirty years, the province of the field of forestry has greatly expanded. Forestry is intimately entwined with the daily lives and welfare of a very important portion of our people. This social and economic integration has come to be recognized and better understood both by the technicians engaged in the profession and by the public. Furthermore, it is due in no small measure to some of the concepts of the recent conservation and relief programs in which forestry has played such an important part.

Already much of our lumber production from the South, North, and East comes from second-, third-, or fourth-growth forests. The small sawmill has replaced the big sawmill unit as the larger source of production east of the Rocky Mountains. Thus the importance and significance of forestry and the part it may play in the life of the nation have been much strengthened and more fully appreciated. Certainly the conservation policies of recent years have greatly stimulated the interest of our people in the part forests may play in our national well-being. 
Forests and employment have been given a new significance. The development, stability, and permanence of our forest communities are being encouraged and appreciated. The interdependence of forestry, agriculture, and industry are being recognized and understood. The

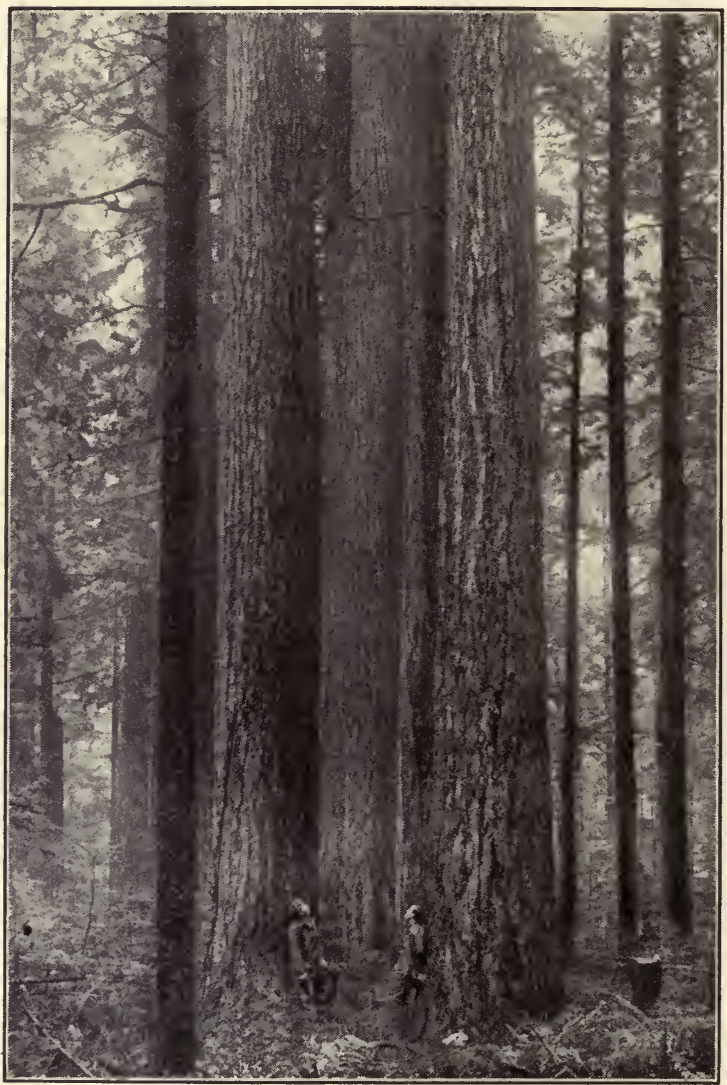

Fig. 2.-Excellent specimens of virgin Douglas fir 5 to 6 feet in diameter with 80 to 100 feet of clear trunks without branches. Some of these trees may produce 15,000 board feet or more each. This tree produces a high grade construction lumber which is shipped in large quantities via the Panama Canal to the Atlantic Seaboard. Some acres contain as much as several hundred thousand board feet. The average virgin, merchantable stands contain 50,000 to 60,000 board feet per acre. About $62 \%$ of all the nation's saw timber is found in the 3 Pacific coast states, principally in Oregon. Photo by J. D. Kress.

social possibilities of forestry and the work of the woods are being integrated with our national life. Forestry includes the conservation of timber, grazing, water flows, scenery, wild life, and recreation facili- 
ties, as well as the development of forest communal life and the production of materials for the maintenance of industry.

Transportation has been an important problem in our forest areas. Forests naturally lie in rather remote and inaccessible regions or even in the wilderness. The desire to make these areas accessible for recreation, hunting, and fishing, the restoration of health, and the enjoyment of the scenery under the most attractive and healthful conditions, has induced the construction and improvement of transporta-

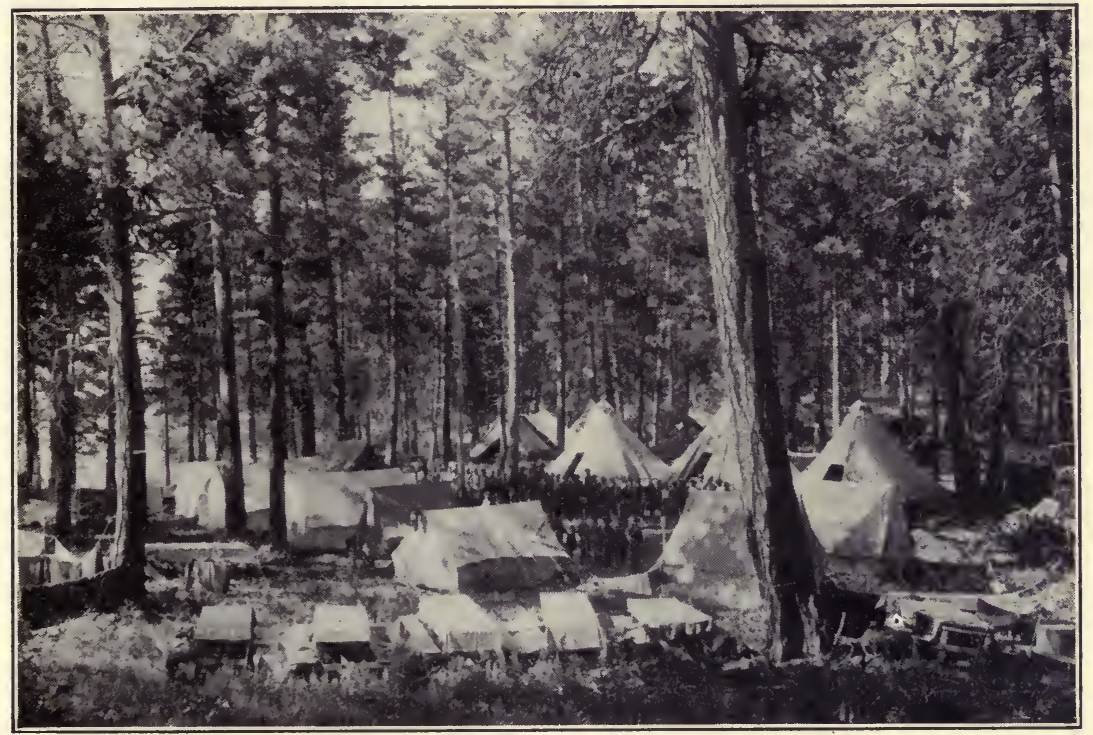

Frg. 3.-Boy Scout camp in the Flathead National Forest, Montana. The scouts are assembled for roll call and flag raising. Recreation camps have been established in our forests in all parts of the country.

tion by highway, rail, or water. These same facilities also make possible the easier removal of the products of the forest. The materials may be timber, minerals, sheep for wool or mutton, cattle for beef and other meat products, furs and other by-products of game animals, resin for the manufacture of naval stores, as well as many other commodities. The principle of sustained yield management* of our forests has therefore been greatly broadened beyond the primary objective of timber production of materials for shelter and construction.

Forestry has to do with trees individually and collectively. More than one thousand species of trees are recognized in the United States.

* This and other technical terms used in forestry are explained later in the text or in the selected bibliography found in the Appendix. 
This nation was exceedingly fortunate in having possession of the richest and most valuable forests to serve every utilitarian need of mankind. From trees and forests are obtained a vast array of products useful in arts and industries in addition to lumber, fuel, paper, and other major products. From trees, either native or exotic, are manufactured gums, syrups, fibers, laces, oils, perfumes, dyes, drugs, chemicals, tannins, food, beverages, tar, pitch, turpentine, paint, rubber, and cork. Trees are the highest expression of plant life. Some

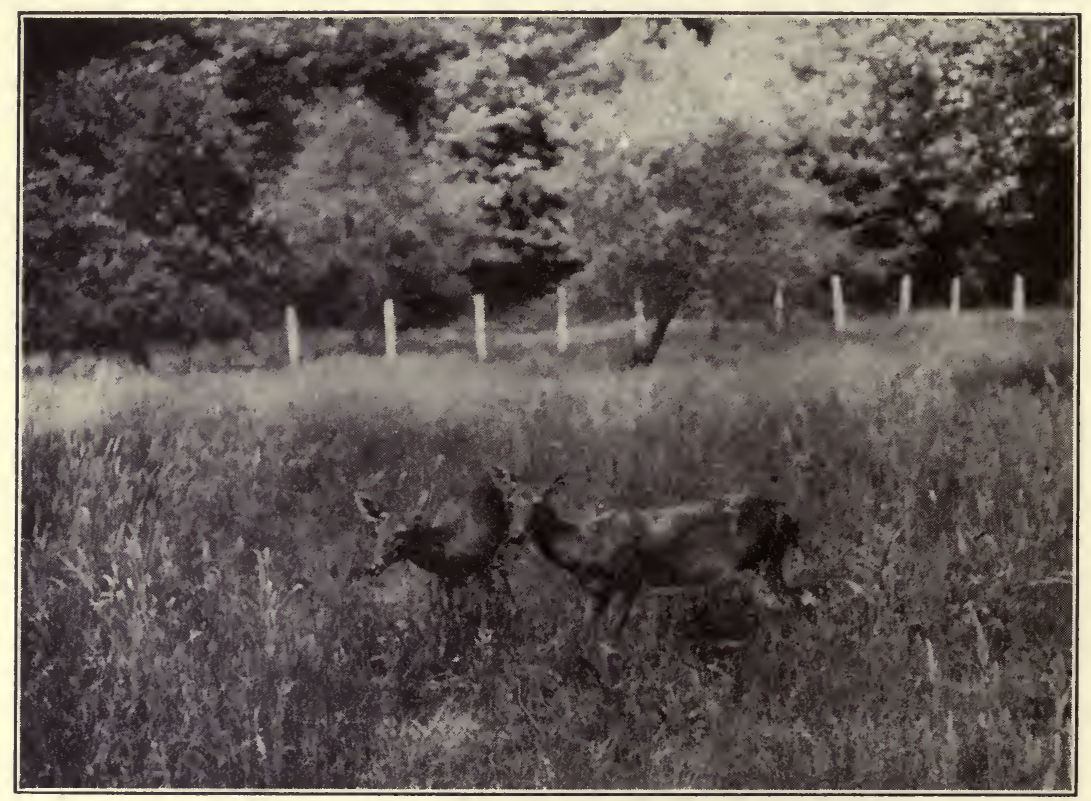

Frg. 4.-Deer in Wayah Game Preserve, Nantahala National Forest, North Carolina. Game management, timber growing, watershed protection, and recreation may be practiced on the same areas without conflict of objectives. Some areas may be closed to hunting, others developed chiefly for grazing or recreation. Multiple purpose forestry is being accepted and adopted in many of our public and privately owned forests.

trees, like the giant sequoias of California, are the largest and oldest living things, their ages ranging up to about three thousand years. Some of these magnificent specimens of nature's handiwork are more than thirty feet in diameter and three hundred feet in height. The balsa wood of South America is lighter in weight than cork and serves many useful purposes. The greenheart and lignum vitae are exceedingly heavy and durable woods. The Panama canal gates are built of greenheart. Lignum vitae is used to make bowling balls, and for 
other applications where a hard, heavy wood is required. Quebracho from Paraguay is so hard that a strong nail cannot penetrate it even under heavy blows.

The study of trees and how best to grow them under a great diversity of climatic, altitude, and soil conditions, and how to convert trees and their products best to serve mankind, is most fascinating and absorbing. Recent in its interest and application in this country, for-

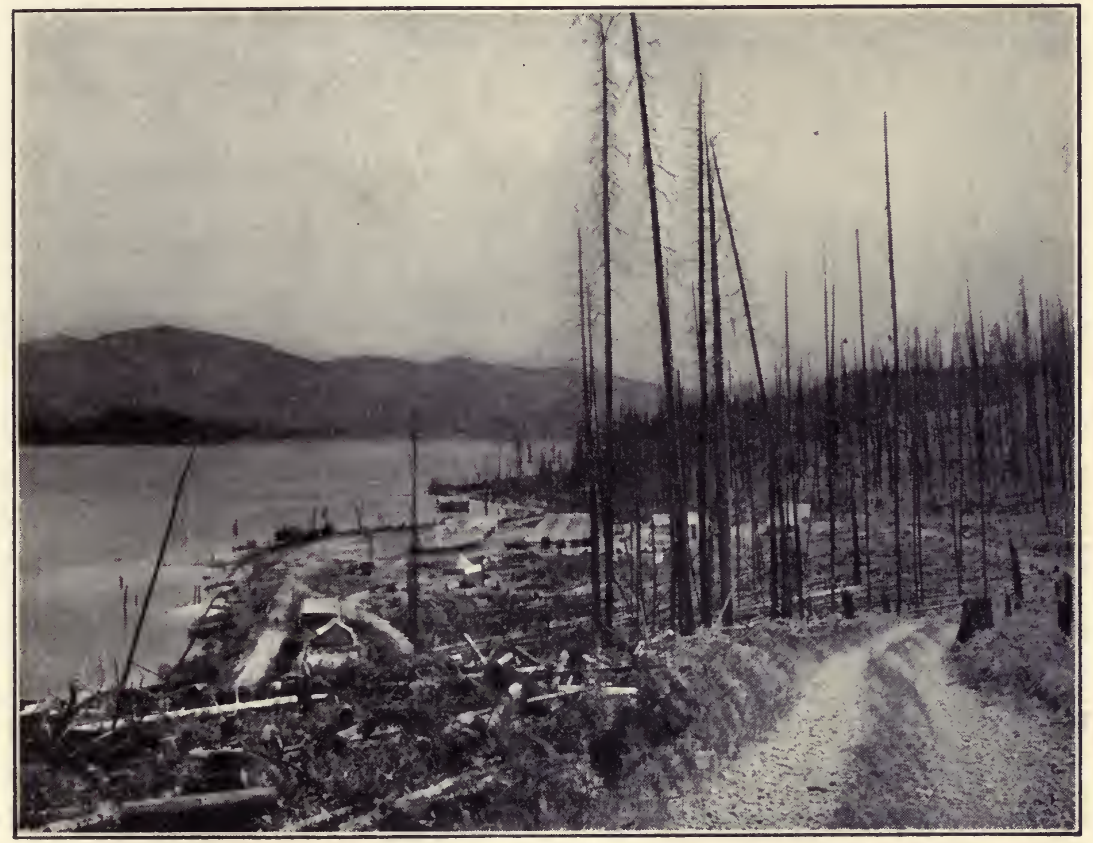

Fig. 5.-One of the many hundreds of Civilian Conservation Corps camps located in the western National Forests. This is a tent camp along Priest Lake in northern Idaho in a forest completely destroyed by fire. These snags (standing dead trees) will be cut and the area reforested by planting western white pine and ponderosa pine trees.

estry has been practiced in Europe for several centuries. The forests of Sweden, Denmark, and Finland are so vital in their domestic and foreign commerce, as well as important in their social benefits, that wide popular recognition is given them. The author believes that, in the coming years, forestry will receive the recognition it deserves in its application to the daily lives and welfare of large numbers of our people.

Forestry has shown the way to national and regional land plan- 
ning. Surely the nation must have a program of planned economy for a resource which is renewable and capable of yielding such a myriad of benefits to mankind. Prior to our federal and state policies of forest conservation, which were inaugurated early in this century, we paid little if any attention to this valuable resource. For many decades prior to 1900 , our policy was characterized by wasteful exploitation, frequent and destructive forest fires, negligence toward young and growing forests and their possibilities, and an attitude of indifference toward forest insects and diseases. Our forests were once considered inexhaustible. A laissez-faire attitude toward our forests and soil resources was widespread. The same attitude was largely displayed toward the non-renewable resources such as oil, coal, iron, and other metal deposits. Farmers have been exceedingly wasteful of our soil resources. The last westward frontiers have been discovered and developed; the expansion of our population into the great agricultural belt of the Central West and across the Rockies to the Pacific Slope has slowed down. An agrarian people has quickly changed its occupations to industrial vocations. The growth of great urban, commercial centers replaced agricultural expansion and development. Social and economic forces have been seeking readjustments in our living conditions and our thinking processes. Conservation is replacing the spirit of widespread exploitation in many of our national habits and methods. Primitivism which signalized our attitude toward our forests is being replaced by a recognition of their worth for present and future generations. The values to be derived from their perpetuation and conservation are being widely realized. Today forestry is a recognized profession, charged with the responsibility of managing and putting to the best use a considerable share of the entire land surface of the United States.

Thus it is indicated that forestry is a combination of those things that have to do with trees and forests. It embraces the field of planting trees, of properly cultivating our forests to obtain the best results, the harvesting of the mature forests, together with the conservation of the products to serve mankind. The broad field of recreational use, with the closely related hunting, fishing, and game management, is also involved in the study of forestry, as well as the protection of the forest against fire, insects, disease, rodents, erosion, and the influence that forests may have upon water flows.

The reverse of planned forest economy is found in the experience of other countries, such as China, Palestine, and Spain, where forests have been denuded and burned until many mountains are barren of forest cover, erosive floods are prevalent, top soils are washed to lower 
levels, and much wood must be imported at great expense to the people.

\section{WHY FORESTRY IS NEEDED-SUMMARY OF OBJECTIVES}

Approximately one-fourth of the land area of the United States, or approximately 500,000,000 acres, is forest land, and a still larger area, perhaps $600,000,000$ acres, is potential forest land. This latter area is greater than the entire land surface east of the Mississippi

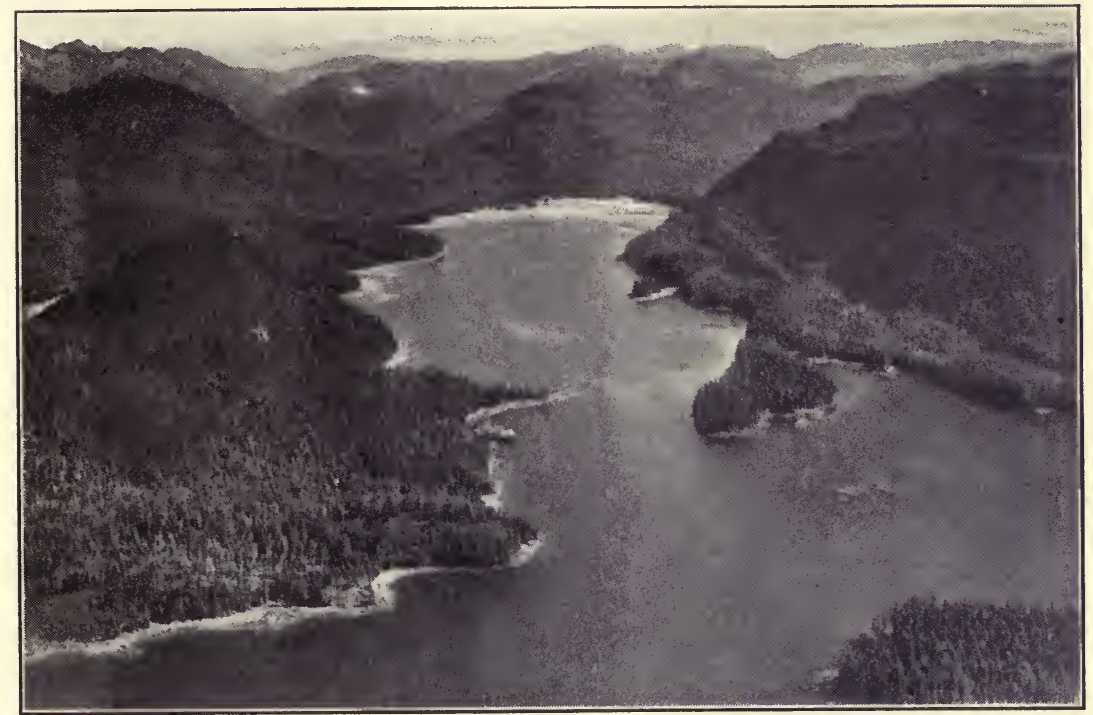

Fra. 6.-The heavily timbered shores of the irregularly indented coast line of southeastern Alaska generally contain from 25,000 to 150,000 b.f. per acre. It consists largely of western hemlock with smaller quantities of Sitka spruce, western red cedar and Alaska cedar. Photo taken on the north arm of Hood Bay.

River. It is vitally important that some national plan be devised for the management and care of this vast domain in order best to serve the needs of the nation.

In normal times we have been using our forests more rapidly than they have been growing. It is vitally important that a permanent timber supply be assured for the future generations of the country. Forests may serve many purposes in the life of the nation. The objectives sought are closely related. They may be summed up as follows. They are not listed in the order of their importance because in some regions one objective may be far more important than another. 
1. The Production of Wood for Construction Material. Shelter, next to food, is of major importance in our daily lives. An abundant, readily available, and reasonably priced supply of lumber and other forest products must be assured for future use.

2. The Conservation of Water Supply. Water is of vast importance, not only for potable supplies and for irrigation, but also for furnishing the source of electric energy, the maintenance of a proper level in our canals and navigable streams, the prevention of floods, erosion, and silting of streams, and allied purposes. The maintenance

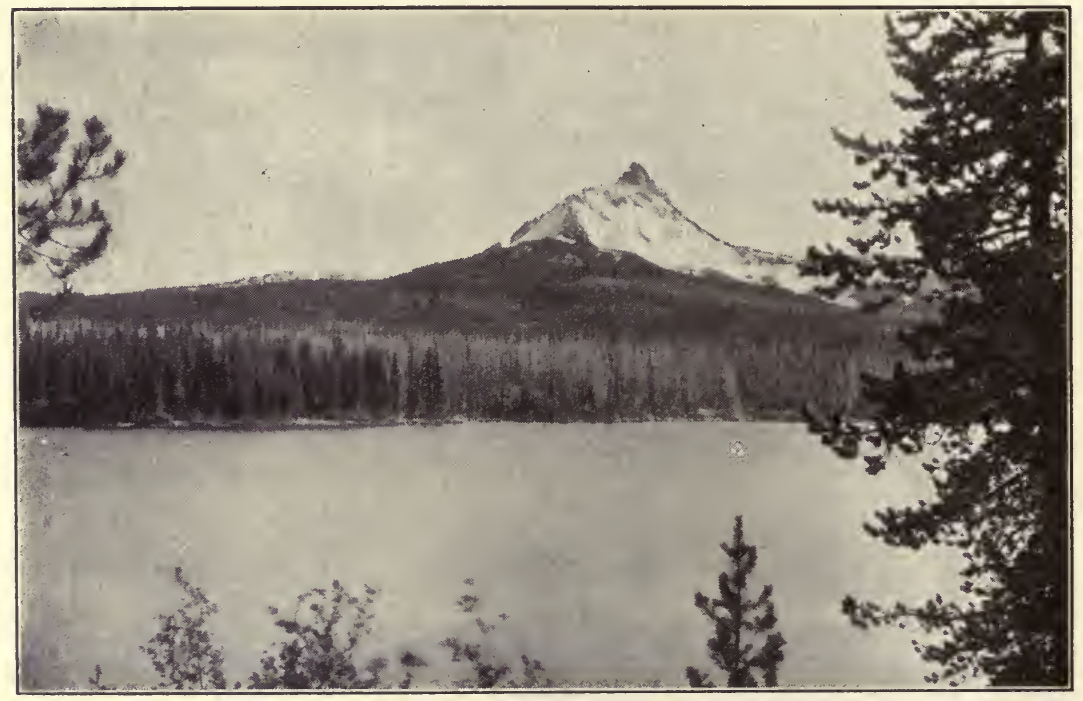

Fig. 7.-Mt. Washington looking across Big Lake, Santiam National Forest, Oregon. Some of our virgin wilderness areas should be maintained in their pristine beauty unspoiled by commercial development for the enjoyment and pleasure of future generations.

of a favorable water table in our soils is vital in some sections, as in southern California.

3. Provision for Adequate Recreational Facilities. During pioneer days, people had little interest in the forests. With the almost universal use of the automobile by our people and the development of excellent highways, many are enjoying the forest as a source of recreation. Millions are visiting our National and State Forests and our National Parks for refreshing their minds and bodies. The forest has assumed a recognized value for recreation in an inexpensive and primitive fashion. Recently, in one year, there were four million visitors to our National Parks, thirty-five million to National Forests, 
and about fifty million to State Forests and Parks. With a growing population and increased time for leisure, more people are likely to use our forests in the future.

4. The Development and Propagation of Wild Life. The forest is the natural habitat of fur-bearing animals and game. Many of our forest streams supply excellent fishing facilities. Denuded and burned watersheds vitally affect the amount and kinds of fish and

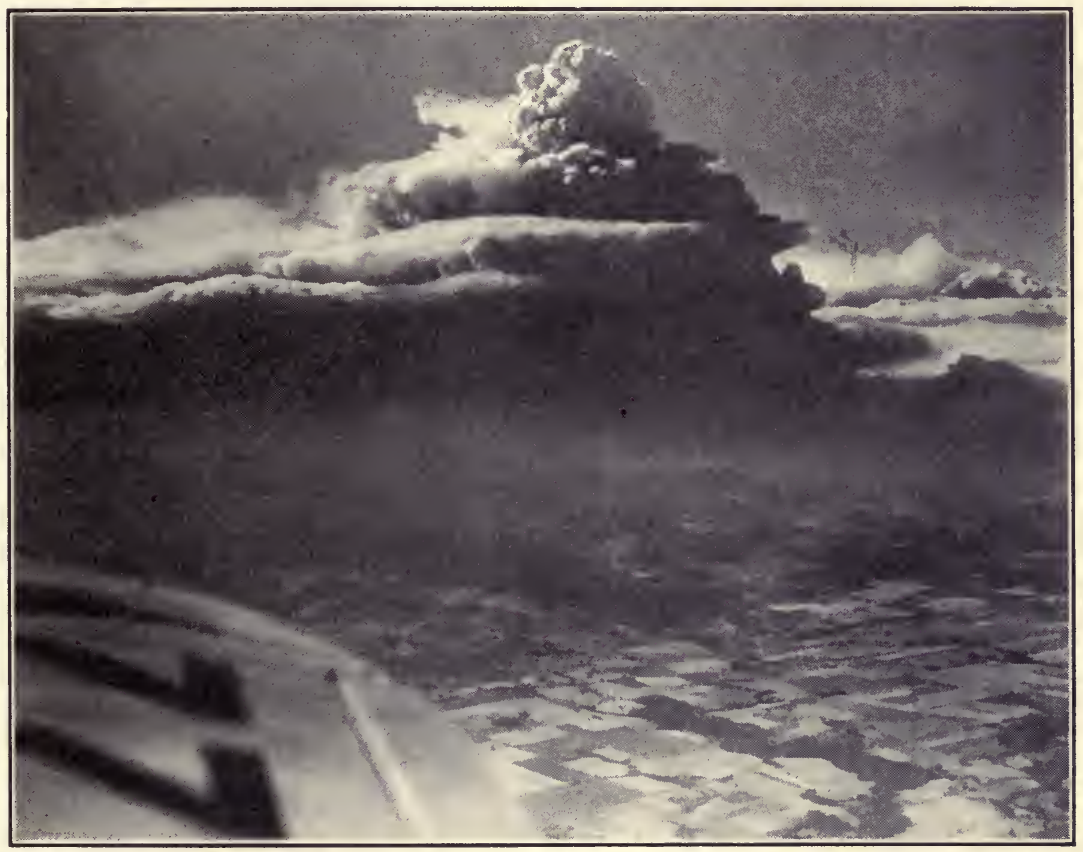

Fig. 8.-The great Tillamook fire of August, 1933, in Oregon, which covered more than 300,000 acres, burned for 11 days and killed over 11 billion board feet of valuable timber, resulting in a loss estimated at over two hundred million dollars. This view was taken from a plane at 9,000 feet altitude, 35 miles distant from the fire. The height of the smoke column was about 40,000 feet and the fire front was 25 miles wide. Ashes from this fire were deposited in Portland many miles away.

game available. About thirteen million people enjoy hunting and fishing each year. To supply adequate hunting and fishing in our forests is an important part of forestry. Many game refuges, breeding grounds, and wilderness areas are being reserved for game management and protection.

5. Forests as Livestock Ranges. In many parts of the country, notably in the West, many millions of cattle, sheep, horses, and goats 
depend upon grazing in the National, State, and private forests as well as on Indian reservations for their summer feeding grounds. There are 83,000,000 acres of National Forest range land. The management of forests may include the maintenance of grazing facilities in many parts of the country. In farmers' hardwood woodlots, grazing may be injurious to forest growth.

\section{The Development and Maintenance of Scenery and Aesthetic} Values. Although closely related to recreational facilities, the aesthetic effects in our forest regions as well as in the Great Plains are coming to be valued and encouraged. Forestry has a definite obligation to maintain the beauty spots and outstanding scenic features for the benefit of future generations. On all the National Parks and Monuments, and on many of the National and State Forests, this phase of the subject is receiving considerable attention.

7. Employment. The best and most efficient development and use of our forests mean the giving of employment to large numbers of people. The value of the products of our forests has averaged about $\$ 2,000,000,000$ a year in normal times. The forest and woodworking industries directly employ about $1,300,000$ workers, or about $21 / 2 \%$ of the gainfully employed people of the country. The building industry depends largely upon forest products and gives employment to an additional 2,500,000 people. The number of people employed in our forest industries exceeded 50,000 in each of ten states of the nation. In Washington and Oregon about 135,000 persons, or one-eighth of all those gainfully employed, were so engaged. Forest industries brought approximately $\$ 250,000,000$ annually into these two states. The perpetuation of our forests to furnish employment to large numbers of people would be a sufficient objective in itself to justify a comprehensive national plan of forestry for the United States. On the basis of the number of wage earners, the lumber and timber products industry (sawmill and logging operations) are in normal years the leading industries in the states of Washington, Oregon, Mississippi, Idaho, Arkansas, New Mexico, Florida, Louisiana, and Montana. The industry was first in total wages paid in all these states as well as in California.

In Europe, under sustained yield management, forest employment is closely associated with farm work and the wood-using industries. On the basis of full-time employment, about one worker is required for every 100 acres of forest in Austria and Switzerland, one for every 125 acres in Denmark, and one for every 167 acres in Prussia. In Czechoslovakia, there is one worker for every 35 to 50 acres, including the industries. When work in logging, transportation, manufacture, 
and the industries is included, generally about three times as many men are required as in strictly forest work.

8. Influence on Climatic Factors. Forests are generally recognized to have a very definite effect on climate. Forests tend to ameliorate the extremes of temperature. Hot summers are generally made cooler by the presence of large numbers of trees. Forested regions are generally less affected by cold weather than treeless plains. Trees when

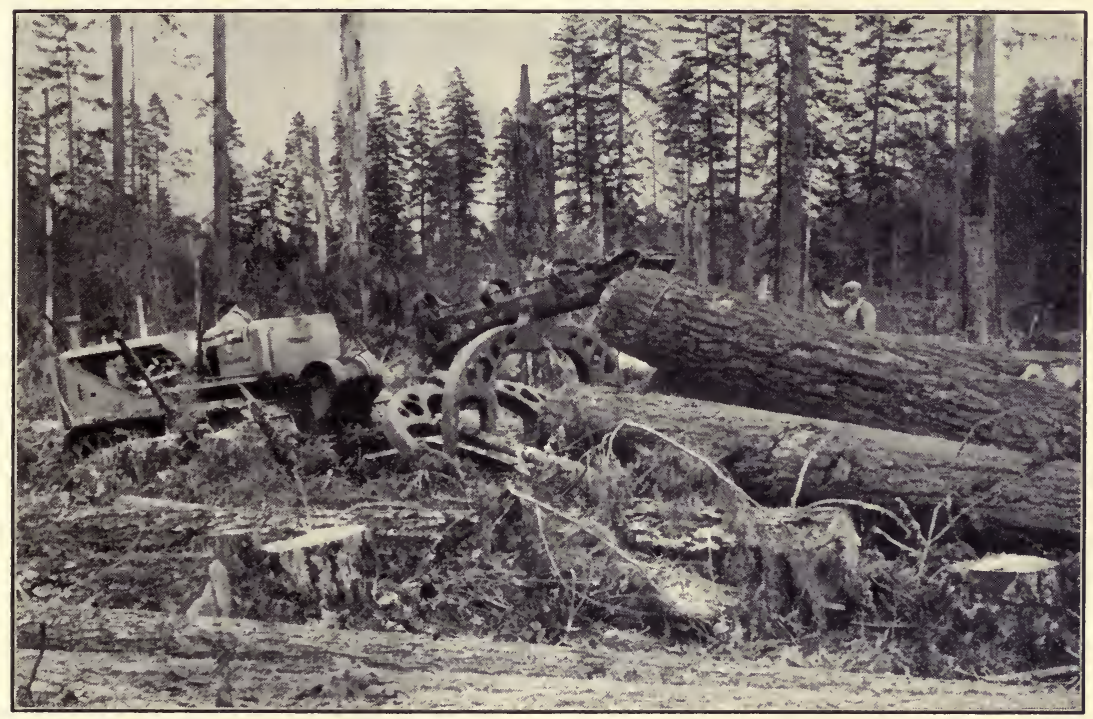

Fig. 9.-A Caterpillar Diesel 75 h.p. tractor bringing in several logs with HysterWillamette arch. Choker lines of steel cable are placed around the ends of each log and brought up and underneath the load to facilitate skidding and reduce tractive resistance. These tractors are replacing railroad spur line tracks and power skidding under some conditions. Tractor skidding is much less destructive to reproduction and young growth than power skidding. Tractors are used with selective logging which is a silvicultural as well as utilization phase of forestry. Logging is when our forests may be best treated to insure future growth. The axe is the best silvicultural tool.

grouped together in rows as shelterbelts have a marked influence in decreasing the extreme chilling effects of winter winds. The transpiration of large quantities of water through the leaves of trees definitely cause forests to be cooler than treeless areas in the same region. Forests also serve as snow breaks and they are extensively used for shade for both man and beast. 


\section{EUROPEAN METHODS CHANGED TO FIT AMERICAN CONDITIONS}

Forestry has been successfully practiced in many of the European countries for several centuries. Ideal conditions for profitable and successful forestry prevail in central and western Europe. The dense population, scarcity of areas available for timber growth, and paucity

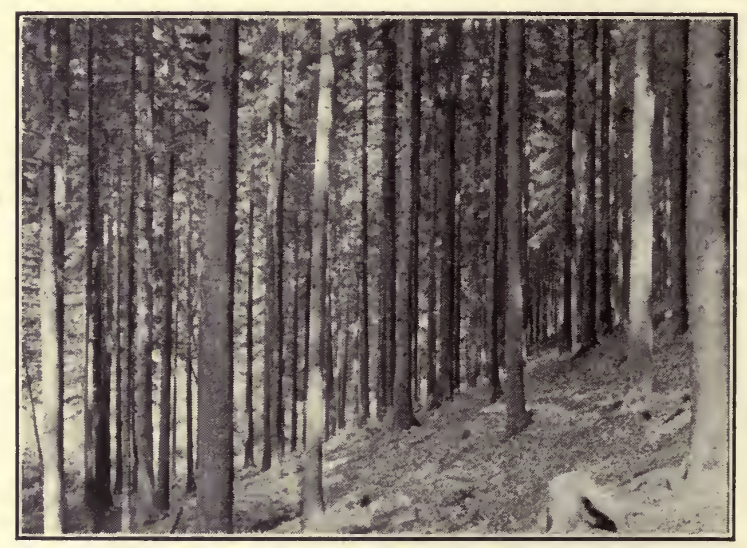

Fia. 10.-A good stand of nearly mature Norway spruce in Saxony, Germany. There is a strong tendency toward the logging of smaller sized trees throughout the East and South in the United States. Forests handled under a systematic plan of management as in Europe mean the production of trees that are small, symmetrical and clean of limbs. Our forests generally grow more rapidly than in Europe. When our virgin forests are cut, logging practices will be simplified and the tendency toward truck and tractor transportation will be greatly increased. This stand contains about 10,000 board feet per acre and has been thinned several times to increase the rate of growth. Photo by the author.

of available forest products resulting in relatively high prices for them constitute ideal conditions. In spite of the intensive development of forestry, many of these countries such as Germany, France, and Belgium, are extensive importers of lumber and other forest materials. Although these products are generally expensive and every effort is made to replace wood by the substitution of other materials, there is a very extensive demand for wood. Even under ideal conditions, modern civilization cannot satisfactorily get along without wood for shelter or the four thousand distinct and separate uses for which wood has been demonstrated as the best available material. The per capita consumption of forest products is very much lower in Europe than in this country. It is estimated that probably 80 to $94 \%$ of all wood grown in Europe outside of Russia, Finland, and Sweden is utilized, whereas in this country only $34 \%$ of the trees felled in our forests is ultimately utilized in one form or another. 
At first, attempts were made to emulate European methods in the management of our American forests. But European methods of planting, cultural thinnings and improvement cuttings, as well as silvicultural systems of reproduction and utilization practices cannot be readily adjusted to fit American conditions. Forestry is intimately related to the social and economic structure of any civilization. Until wood becomes much more scarce and therefore more valuable, we will be able to practice only an extensive rather than an intensive system of forestry in this country.

In Europe, the largest trees are generally utilized for saw logs; smaller trees of spruce are used for pulpwood, and the balance of the tree stem is utilized for fuelwood or other purposes, including the smallest limbs and twigs. Bark of one of their principal trees, Norway spruce, is stripped and used in tanning. In extreme cases stumps are grubbed out and used for charcoal and fuelwood. Even the leaves and forest litter serve for kindling. Fuels such as coal and wood are scarce and therefore command attractive prices on their markets. The keynote of commercial forestry is the ability to sell the products at a good profit.

A technique and system based upon an American form of silviculture, and a forest practice founded upon our social and eco-

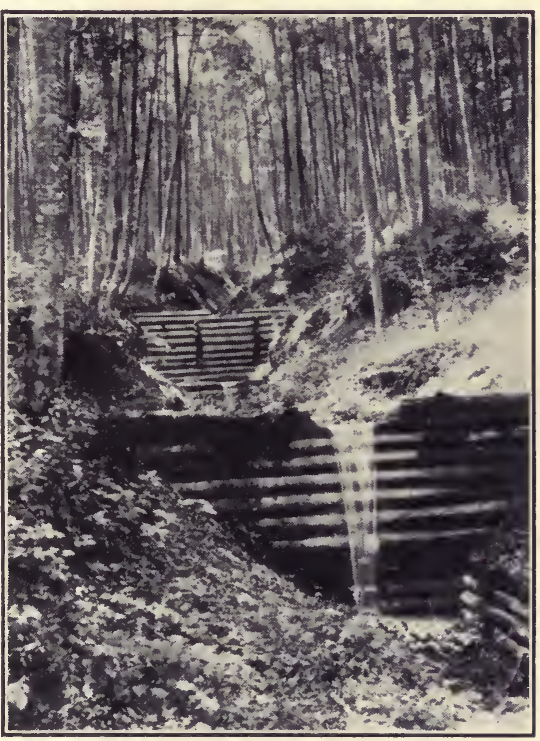

FIg. 11.-Control dams as used in Switzerland. For many years, erosion control has been an important part of the forestry operations in the mountainous sections of Europe. The importance of erosion control and the part forests play in this work has recently been recognized in the United States. Photo by the author. nomic conditions, must be evolved, instead of following materially in the pathway of European forestry. One very important lesson that we may learn from European practice is that lumber and other materials are generally produced from a large number of relatively small but permanently located sawmills and forest industries. This condition results in the stabilization of employment as well as in location of industry. This is in marked contrast to the past nomadic character of our sawmill industry where mills 
established for cutting a given tract were dismantled and towns abandoned when the virgin timber had been removed. The stabilizing of our sawmill communities and the permanence of mill locations will contribute much to the employment and social welfare of our people. It is very doubtful if we will ever be able to practice the intensive forms of silviculture and forest management which one admires so much in European forestry, as in the Black Forest and the Saxon forests of Germany, the Swiss forest of the Sihlwald near Zurich, the Italian forest of Vallombrosa, near Florence, the famous municipal forest of Epinal or the beautiful forests of Compiegne, Fontainebleau, and Versailles in France.

\section{FORESTRY AS A PROFESSION}

Forestry is relatively young in this country. It is an old and respected profession and occupies an important position in the national life of many European nations. Work in the forestry profession requires a thorough grounding in and knowledge of our social order, our economic and political systems, business methods, and professional ethics, as well as a comprehensive understanding of trees, wood, and forests and the part they play in our national economy. The subject requires a complete understanding of the tree as a plant, how it grows and reproduces, singly and in association with others, and how each species may be best converted into articles useful in commerce and industry. A study of forestry and its component parts generally requires four or five years of college training, and frequently additional years for specialization and training in advanced phases of the subject. Recently, forestry has assumed such a significant place in the life of the nation that it is becoming recognized and accepted as an important and integral part of our activities.

The conservation of our natural resources is one of our great national problems. The ideals and purposes of forestry were for several years in direct conflict with many of the accepted and established customs and practices of the country, notably in the West. Many prejudices against and much opposition to the accepted principles of forestry had to be overcome. The forester, therefore, must in many respects be a good missionary to help to educate the public about the value of forests. As in law, medicine, theology, engineering, and other professions, adequate training in the ethics, ideals, and standards is necessary, as well as in the principles and practices of forest conservation. Forestry deals essentially with the woods and with the business of converting the products of the forest into useful materials. 
There should, therefore, be a genuine interest in the principles of forest conservation. There should exist in the prospective student of forestry a real love of the forest and of the objectives of the profession. Both a sentimental and a practical interest in the woods is very necessary.

Many young men are attracted to the profession as a result of their camping, hunting, fishing, picnicking, or tramping experiences in the woods. Perhaps a vacation spent in a Boy Scout camp, or a

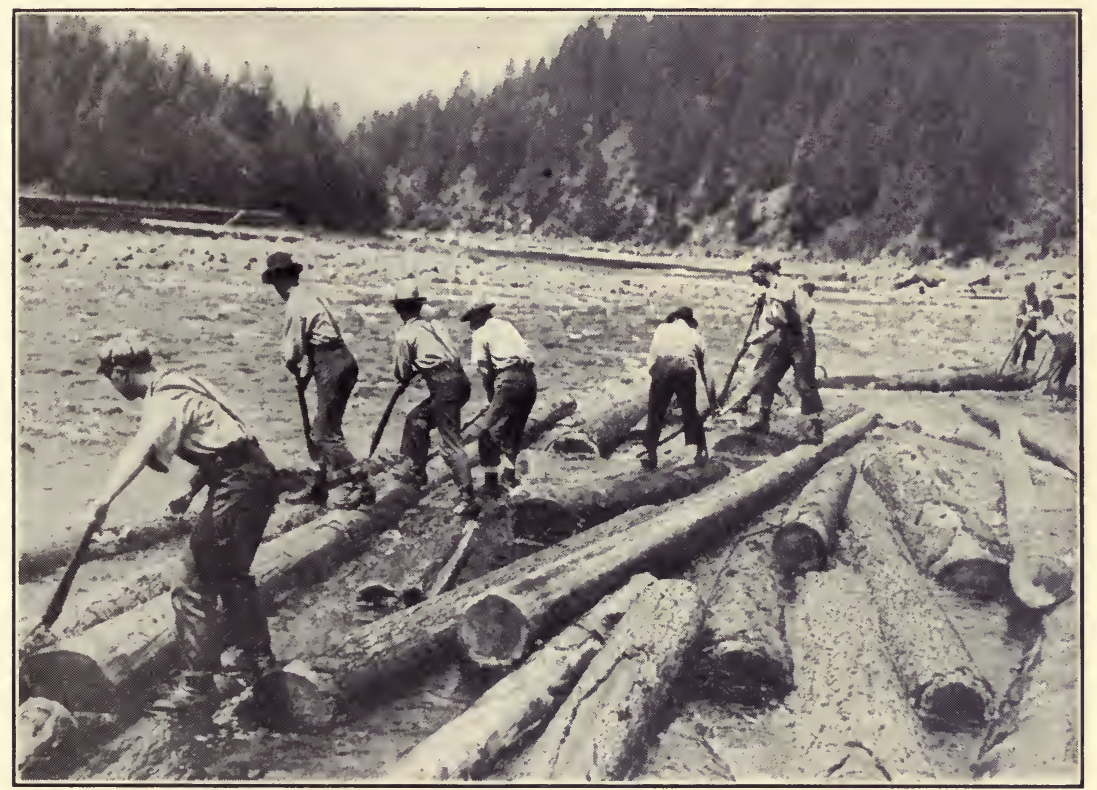

FIG. 12.-A driving crew moving logs with peavies into the main current of the Clearwater River, Idaho. Forests and forest industries furnish employment for over one million men. It is important that forests be maintained, protected and regrown to keep these industries operating on a permanent basis.

school or vacation camp in the woods, has aroused one's latent primitive interest in the forest. Everyone naïvely likes to "get back to nature." The rushing brooks, the wild flowers, bird life, magnificent scenery, the challenge of mountain climbing, or the study of the varieties of trees, flowers, birds, and insects, may be the initial entrée to the subject. There is a healthful, natural reaction of young men to the many interesting phases of life in the woods. This is most admirable and commendable, but the impressions of these first ventures into the realm of forestry are generally made under the most favorable circumstances such as plentiful and wholesome food, a warm, com- 
fortable bed, good water, stimulating companions, and pleasant scenery and surroundings. These are naturally conducive to developing one's interest in the woods. Some have read stories of forest rangers, or seen rather romantic pictures of them riding about the wilderness trails on horseback.

The work of the forester may include all these attractive features, but it may also mean working under the most difficult and arduous conditions of cold weather, rain, snow, or excessive heat. Fighting forest fires may mean working steadily for twenty hours or more

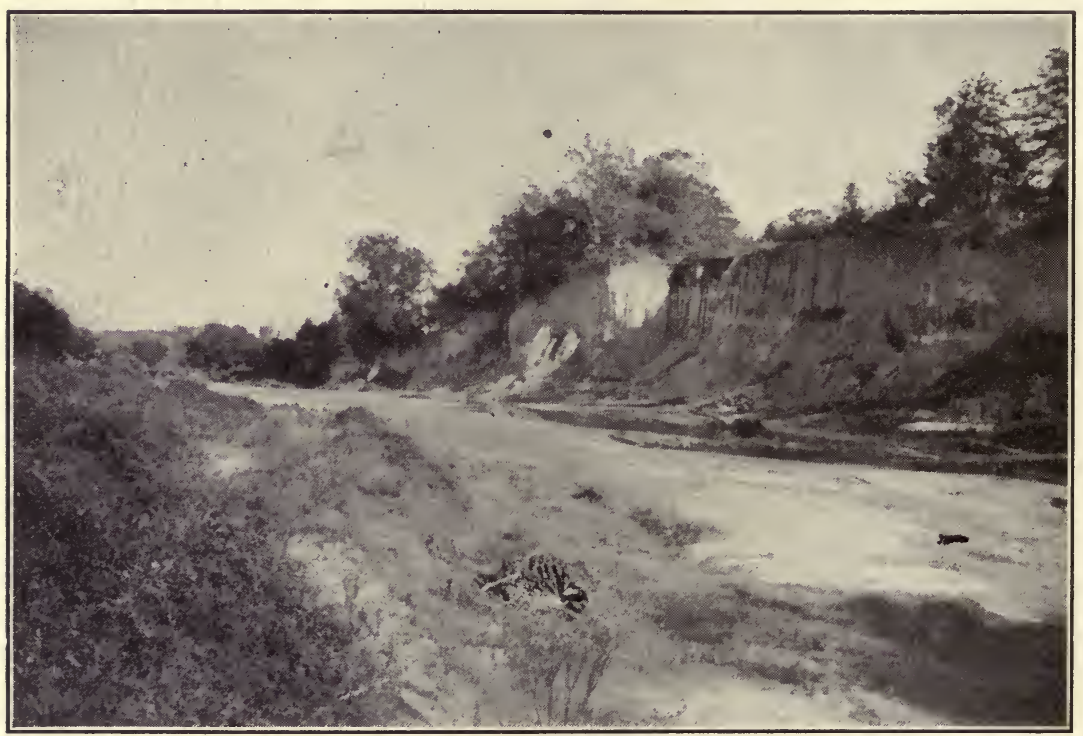

Frg. 13.-Serious and advanced stages of erosion along Little Bayou Sara in Louisiana. Adequate control of erosive slopes is an important part of forest conservation. Photo by G. H. Lentz.

under the most trying conditions of smoke and heat, with little or insufficient water and food. Timber appraisals are sometimes made in winter on snowshoes, or in swamps where one is wet most of the day. One must appreciate that, during an apprenticeship period of several years, a young graduate forester may spend much of his time in the woods far removed from the customary pleasures and surroundings of urban life. Frequently strenuous physical labor under adverse conditions is required, so that a vigorous, healthy physique is desirable. Fire fighting, wood chopping, construction work, trail building, surveying, timber estimating, and logging work may require one to carry a heavy pack, or burdensome instruments, up steep mountains, in 
dense timber encumbered with windfalls, or may necessitate wading in streams. One should be familiar with horses, canoes, and woods tools, as well as with automobiles and perhaps with the diamond hitch or tump line. Resourcefulness, physical endurance, leadership, and a cheerful disposition are desirable traits in facing many of the woods problems.

The nature of the work may require frequent changes of headquarters, and thus it may be difficult to establish a home until advancement in position may require living in a larger community with

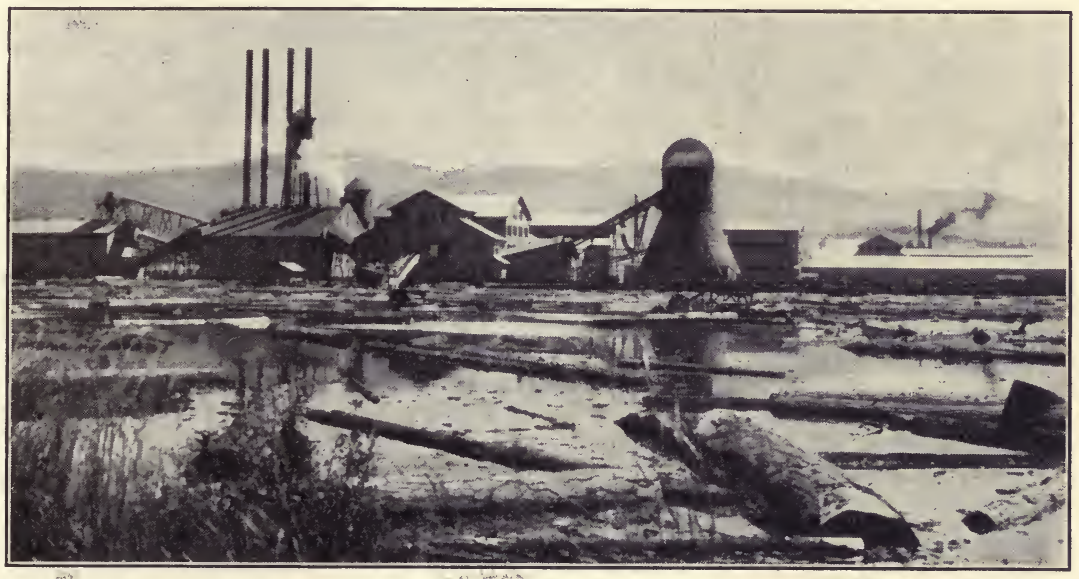

FIG. 14.-Fruit Growers Supply Company's mill and box factory, Susanville, California. This mill cuts 300,000 board feet in eight hours. This was one of the pioneer companies in the establishment of a sustained yield plan of forest management on their extensive timber holdings of about 142,000 acres. This company is owned by an association of fruit growers to supply wooden boxes for fruit shipments. It also sells lumber in the open market. In the left center is the jack-ladder to haul logs from the storage pond to the second floor of the mill. Refuse burner is shown at the right.

greater opportunities for home life. Those occupying administrative positions of responsibility may be expected to spend from 35 to $65 \%$ of their time in the forest or away from home, supervising, directing, and inspecting the work of others. One must be adaptable and socially minded to get along with all kinds and conditions of people who are earning their livelihood from the woods. If one is industrious, lends oneself to the work at hand, exercises good judgment, gets along well with his superiors and subordinates, there are ample opportunities for success. A forester must love and enjoy his work, his associations, and his profession. There is little that is monotonous about the work. 
New problems, new conditions, new policies, and new developments must be constantly faced and handled. Forestry is a fascinating, constructive, and interesting profession for those who enjoy and are adapted to the life of the woods and the business of converting and utilizing the products.

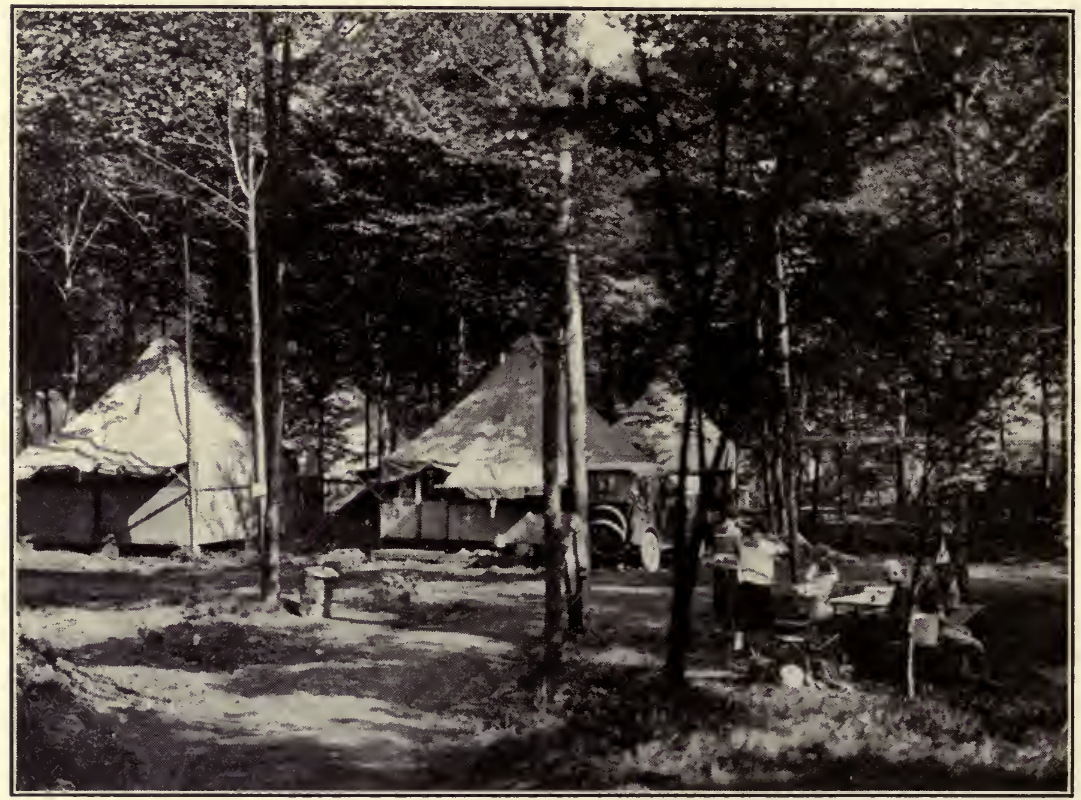

Fig. 15.-Several million people enjoy our National Parks every year and about 35 million people visit our National Forests. Still more visit our State Parks and Forests. The recreational values of forests are coming to be widely recognized and appreciated, with the improved highways, low priced motor cars and the natural human desire to get "back to the woods."

The principal qualifications requisite for success in the profession may be briefly summarized as follows:

1. Thorough technical training in a good undergraduate or graduate school of forestry, involving from four to six years of college work. Here the technique of the subject is learned, as well as the ideals, ethics, objectives, and standards of forestry. The attitude toward the work and the profession developed in a school of high standards may be of considerable importance in the success of the individual. The training should be approximately equivalent to that required of a doctor, lawyer, minister, or engineer. The training should be highly specialized in the theory and practice of forestry, but it 
should also include broad cultural subjects and activities. Forestry deals with people as well as with trees, so that humanistic training is of large importance.

2. Resourcefulness, self-reliance, and honesty. Intellectual honesty is a prime requisite. Men of high integrity are required in both government and state services, as well as in private practice. Frequently men are thrust into places involving great responsibility, initiative, resourcefulness, tact, and diplomacy. A native honesty and strong character are of great importance.

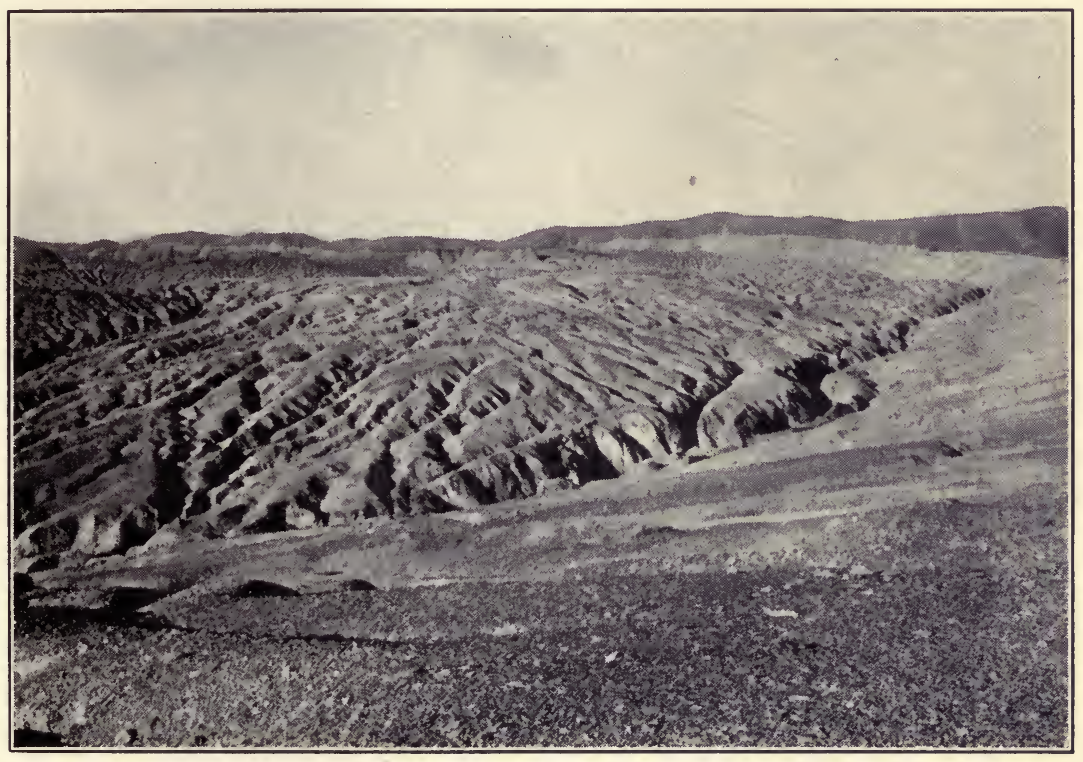

FIG. 16.-Effects of erosion in a region of 60 inch rain-fall following depletion of vegetation by smelter fumes. Copper Basin, Oconee County, Tennessee. This was once a heavily forested region.

3. A strong and healthy constitution. A forester's work may be very exacting, physically as well as mentally. Long, hard trips in remote wilderness areas under difficult climatic conditions by horse, canoe, snowshoes, or on foot are commonplace, especially in inaccessible forest properties.

4. Spirit of public service. One seldom sees immediate results of efforts in forestry. Trees require many years to mature. There must be a spirit of altruism, of making the country a better and happier place in which future generations may live. One looks forward for results not only a few years but for several generations or even cen- 
turies. There are many strong implications of service throughout the profession of forestry. One must be imbued with this spirit of constructive helpfulness in the upbuilding, reconditioning, and maintenance of our forest resources.

5. Executive and administrative ability. The management of large tracts of timberland; the appraisal, purchase, and handling of forest products; and the management of industries dependent upon the forest as a source of raw materials all require men of vision, tact, personality, experience, judgment, and ability.

It is quite apparent from the above that forestry is an exceedingly exacting profession-one that has to do with almost every phase of human activity. Certainly there is little that is monotonous about the work and the life of a forester. He is very likely to travel rather widely and come into contact with many interesting people who derive their livelihood from the woods. It is an invigorating, stimulating and healthful profession and one that challenges the best efforts of those that select it for their life work.

\section{PRINCIPAL BRANCHES OF FORESTRY}

The subject of forestry is generally classified into five principal branches. They are briefly described here in order to emphasize the widespread scope of the subject. Most of them are treated later in the text, especially those of a fundamental and elementary nature. Some subjects, such as dendrology, forest finance, and valuation, are so involved or the field so broad that they are not included in a text of this type.

1. Forest Protection. Forest protection is the safeguarding of the forest against damage or injury. It is fundamental and prerequisite in all forestry work. The principal enemy of the forest is fire. Forest management or any other phase of continued forestry work is impossible without adequate forest fire protection.

Many varieties of insects and fungi attack both living and dead trees. In some regions, protection of the forest from grazing animals is of major importance. Other natural agencies involved in forest protection are atmospheric, such as wind, frost, and lightning, which may cause damage to standing timber. Shifting sands, landslides, and avalanches also are destructive. This subject likewise includes protection of forests against trespass or injury by mankind.

2. Silviculture. Silviculture is the art of producing, reproducing, and tending a forest. It is the application of the knowledge of silvics in the management of a forest. Silvics is the science which treats 
of the life habits and behavior of trees in the forest, and is sometimes considered synonymous with silvicultural characteristics. The handling of forests to obtain the best results in the maintenance of growth and reproduction is fundamental in the knowledge of forestry. The forester must know the habits of trees and the forest influences which affect the life of individual trees as well as the tree community. He

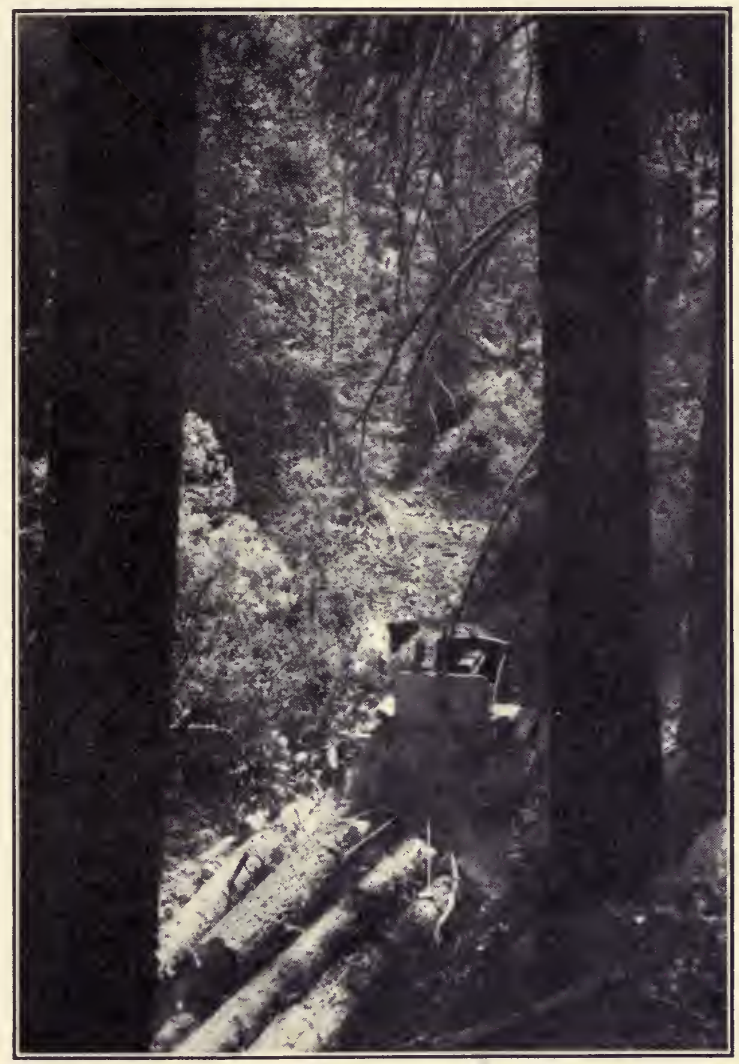

Fig. 17.-A Caterpillar Diesel 75 h.p. tractor skidding logs in the Feather River region of California.

must know how to plant, improve, and cut our forests. In Europe, silviculture is the most important part of forestry.

3. Forest Utilization. Forest utilization is the most profitable and efficient use of forest products. It includes the conversion of standing timber into forms useful in human economy and the arts. It embraces the harvesting of the forest crop, the logging and transportation of the raw material, chiefly logs, to the market, and their manufacture 
into various useful commodities. It also includes the merchandising and distribution of these products. The logging, manufacturing, and distribution of forest products play a very important part in the life of the nation. The main branches of forest utilization are the properties and uses of wood, the cutting of the trees, and transportation of the logs to the manufacturing plant, known as logging, the manufacture, conditioning, and treatment of the products, and the distribution of those products to their ultimate use. Forest utilization generally determines the intensity with which silviculture may be practiced. It is the "bottleneck" through which successful timber growing or forest production must be passed. Until our virgin forest resources shall have been depleted, forest utilization constitutes a most important phase of American forestry.

4. Forest Management is the practical application of the principles of forestry to a given forest area. It embraces such subjects as the measurement of the present and potential yield of the forest, engineering, such as surveying and mapping tracts of timber, road making and the building of forest structures, and such subjects as forest organization, forest valuation, and finance. It includes the making of working plans under which forest properties are continuously managed.

5. Forest Policy and Economics include the principles which determine the administration of the forest for its best permanent management and use. The question of federal, state, and private responsibility in the management of our forests, the manner in which a plan of forestry is adjusted to our social and economic systems, are included within this branch. An important aspect of forest policy is the history and development of the subject and its relation to the political system. of the country. Forest laws and other legislation involving taxation and administration of forests are also included. The part which forestry plays in general land use planning is a subject of large current importance in the life of the nation. The conservation of water, forests, and forage is closely related and integrated.

\section{ARBORICULTURE AND FORESTRY}

Arboriculture deals with the planting, care, protection, and treatment of individual trees, particularly in their use for ornamental or decorative purposes in lawns, parks, home grounds, and along the highways. Forestry is concerned with the growing, protection, and use of large areas of trees. There is a distinction, therefore, between the two. Arboriculture includes what is frequently known as city forestry, municipal forestry, and tree repair. It is an important part of land- 
scape architecture and is closely allied to forestry. It is also regarded as a part of horticulture. The aesthetic use of trees in ornamental treatment and landscape design has become widely recognized and valued throughout the country. From a broad viewpoint, therefore, arboriculture is a part of forestry. Every forester should know how

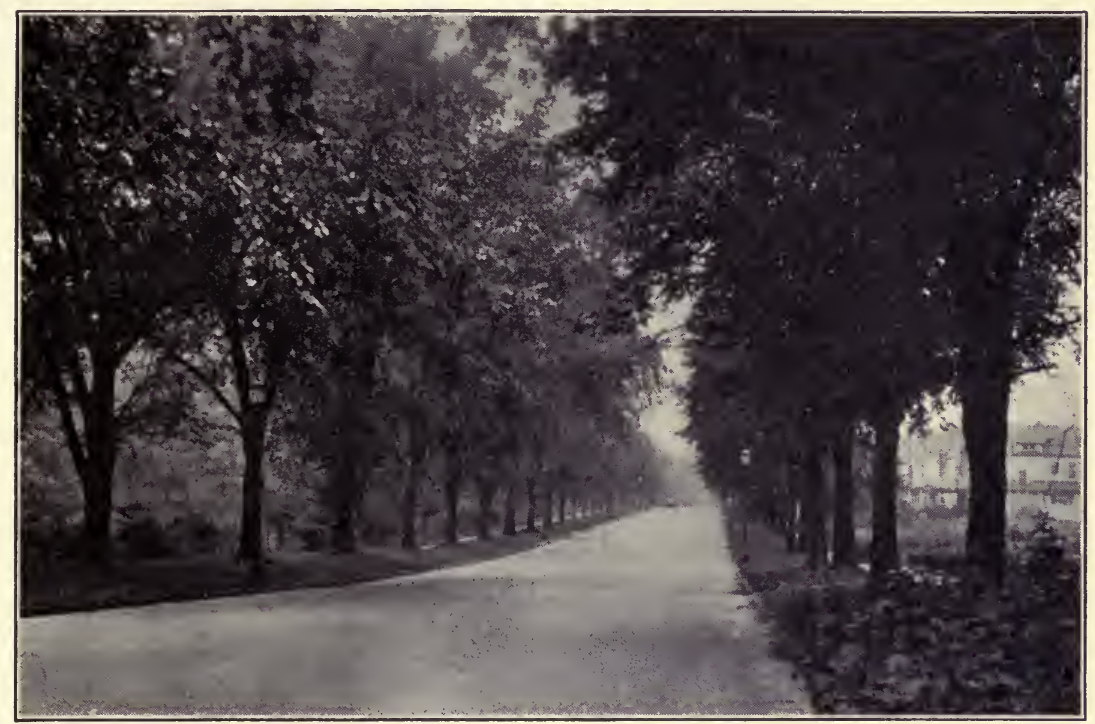

Fig. 18.-A beautiful vista along a highway. Many of our roadsides are characteristically bare of planted trees to furnish shade and protection as well as for the beautiful scenic effects they render and add to the pleasures of motoring.

to plant, protect, repair, and care for individual trees about the home or along the streets and highways as well as large groups of trees known as forests. Many large municipalities have employed city foresters whose duties are the proper planting, protection, and care of street trees and those found in parks and about public buildings and grounds. 


\section{CHAPTER II}

\section{HISTORY AND DEVELOPMENT}

\section{EARLY BEGINNINGS}

Nowhere in the world have the forests more fully met the varied requirements of mankind nor have they proved more beneficial in their utility than in North America. The early colonial settlers along the Atlantic seaboard found a most magnificent forest, rich in variety of both hardwoods and softwoods. Qualities of strength, durability, workability, beauty, and fitness were present in this native timber to meet the needs of either a primitive or advanced type of civilization. During a period of about two hundred years the more fertile and accessible valleys were cleared of timber by an exceedingly slow and extremely laborious process. The early settlers of Virginia, the Carolinas, Massachusetts, New York, and Pennsylvania used the forest first for shelter and fuel. It harbored the hostile Indian and the savage beast, yet provided game for sustenance, and furs and timber for the first export business. Generally the forest was a deterrent to settlement. The dense primeval forest had to be cleared for agriculture, and yet forest conservation was initiated even in colonial days. William Penn required that one acre of forest be left for every five acres cleared in Penn's Woods. Regulations were early passed in Massachusetts to safeguard the future of the forests. To insure adequate facilities for national defense, Congress appropriated $\$ 200,000$ in 1799 to purchase a timber reserve for shipbuilding purposes, and in 1827 an attempt was made to grow live-oak in the Southeast for the same reason. Sentiment in various states began to crystallize in the direction of forest conservation. In 1873, Congress passed the Timber Culture Act. This sought to encourage forestation in the treeless prairie region of the Great Plains by issuing a deed for 160 acres of public domain to any settler who planted and retained 40 acres in timber.

Arbor Day and Its Influence. Arbor Day was conceived and first promoted by J. Sterling Morton, and it was first observed in Nebraska in 1872. Morton was then a member of the State Board of Agri- 
culture and later became U. S. Secretary of Agriculture. The idea of planting trees on the great central plains quickly became popular. The observance of this day has grown rapidly and spread to every state in the union, our territorial possessions, and many foreign countries. Kansas and Tennessee proclaimed Arbor Day in 1875, North Dakota and Ohio in 1882, and thereafter the other states throughout the nation. Usually the day is fixed for each state or arranged by proclamation or at the option of the governor.

Arbor Day has had a profound influence in spreading a better knowledge of trees and an appreciation of their value. Although trees originally were planted for shade and windbreak purposes, the realization of their significance and importance in the life of our people has been given great impetus by an annual observance of this day. Progressive educators have come to realize the need of presenting the forest problem in the schools. This has resulted in the creation of a very helpful understanding among the future citizens of the country. It has no doubt contributed very materially in formulating a favorable public sentiment. This, in turn, has made federal and state legislation for the protection and care of our forests much more simple and easy.

\section{THE PIONEERING AND NOMADIC LUMBER INDUSTRY}

The American lumber industry is the oldest and one of the largest and most representative industries. From the earliest days it has pioneered in cutting down our forests to provide shelter for our rapidly increasing population. Next to food, shelter is the most urgent necessity of mankind. The lumber industry developed primarily along readily available systems of water transportation. This continued almost unbroken during the pioneer and the colonial stages of development until about 1860, when railroad facilities began gradually to replace water transportation in moving logs and lumber to market.

For many years the center of the lumber industry was in Maine. The first sawmill was established in Berwick, Maine, in 1631, although there were said to be sawmills installed after the settlement of Jamestown, Virginia, in 1609, and those driven by the wind in 1622 to 1630 on Manhattan Island, New York City. Until 1840, the lumber industry was centered largely in Maine and New England. Virgin white pine trees were often found from 130 to 160 feet in height and from 40 to 50 inches or more in diameter. It is reported that some even attained a height of 250 feet and a diameter of 80 inches.

In 1850 , New York became the leading lumber state of the nation. 
It produced $20 \%$ of the total lumber supply, and Albany was the great lumber mart. In 1860 the center of the lumber industry shifted to Pennsylvania, and by 1892 the peak production of white pine was reached in the magnificent stands of this species in Michigan. For nearly 300 years, therefore, white pine continued to be the leading lumber tree of the nation. It was the most useful species found in our American forests. Then quickly the lumber industry shifted to the yellow pine forests of the South which were used for the upbuilding of the great central west during the later periods of westward

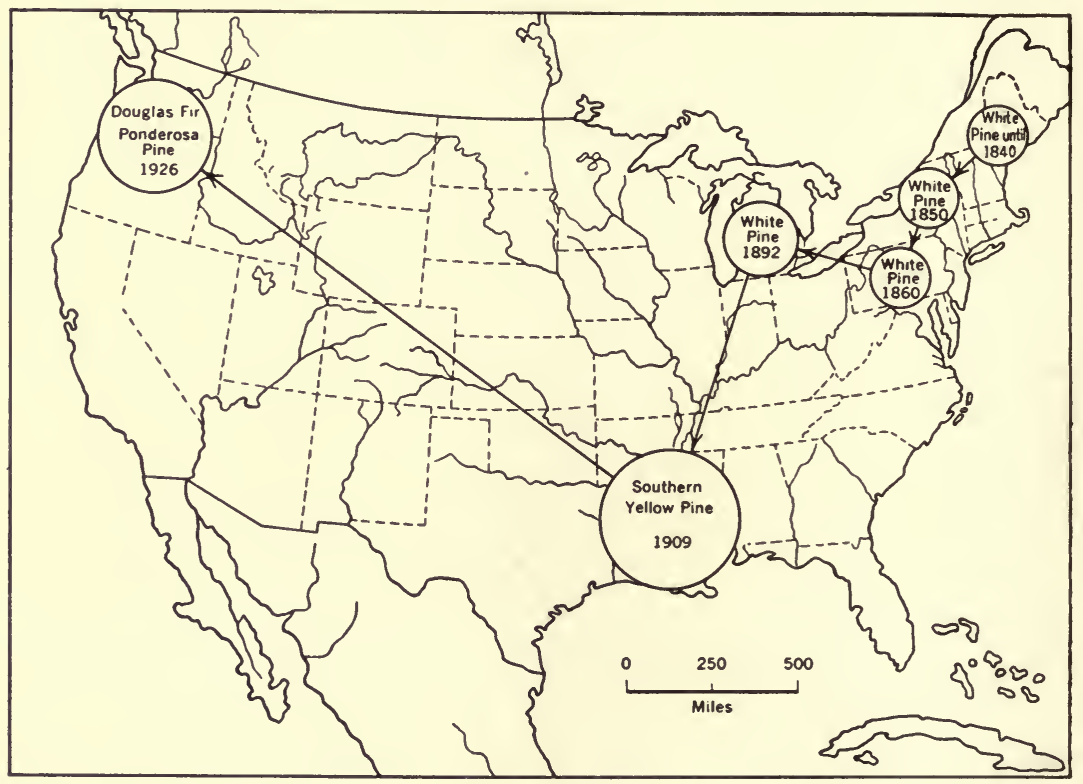

FIG. 19.-Map showing progress of lumber industry with dates of peak production and leading species in principal regions.

expansion and development. The peak of the southern pine production as well as the all-time peak of the American lumber industry was reached in 1909, when 46 billion board feet of lumber from all species was produced. By 1920 the bulk of the virgin timber was removed from the South, and some of the same families who for generations were engaged in the lumber industry, having followed it westward to Michigan and then to the South, now turned to the Pacific Coast. The peak of lumber production in the Northwest came in 1926 when some 8 billion board feet of Douglas fir was produced. Owing to the inroads of substitutes and economic conditions, national lumber production rapidly decreased until in 1932 it sank to $101 / 2$ billion board 
feet, in contrast to the 38 billion feet reached during an average of pre-depression years.

Heretofore, lumber production has largely been of virgin timber. Within recent years, however, under improved methods of fire protection and cutting practices, our second-growth forests are renewing themselves splendidly. For example, the South, up to 1935, still retained its position as the leading center of lumber production in the country. In the four North Carolina pine states, Virginia to Georgia inclusive, the peak of lumber production was not during a period of the removal of the best virgin stands but in 1926, at least a quarter of a century after removal of practically all the virgin timber. It is apparent that the forests are growing up more rapidly than had been anticipated. The fear of a timber famine is no longer felt. The nomadic lumber industry has changed rapidly within recent years. Small mills have replaced the large lumber-production units. Probably $80 \%$ of all the lumber produced east of the Rocky Mountains comes from the small portable and stationary mills. This is an important contribution to the stability of employment, location, and output. "Ghost cities" that quickly rose with the installation of large logging and sawmill operations, and then as quickly disappeared with the removal of the virgin stands, are being replaced by small, permanent communities which are utilizing the products of the forest at nearby sawmills and at various woodworking plants. This is indeed the very essence of good forest management.

\section{PASSING OF THE LAST RESOURCE FRONTIERS}

During recent years the last resource frontiers have been crossed. We have discovered and determined the location of the best mineral, oil, soil, water, and forest resources. The westward expansion and settlement have slowed down. There has been a sharp decrease in immigration and a steady increase in population of about $10 \%$ per decade. There has been a rapid shift from agrarian to industrial occupations, which has resulted in a vast increase in our great urban centers and a decrease of our rural population. Concentration and consolidation of population have replaced the former periods of pioneering and of developing our frontiers. This stabilization in industry, the internal development, the population growth, and the concentration of agricultural efforts on our best soils have directly influenced our forest policies. Thus, per capita consumption of lumber and other wood products has dwindled to about one-half that of 25 years ago, owing to the inroads of substitute materials for wood, the in- 
creased use of natural gas, coal, and electricity instead of fuelwood for cooking and heating purposes, and the decreased construction of frame houses concurrently with changing habits of mankind and the tendency to live in concentrated centers, as in apartment houses.

\section{FEDERAL ACTIVITIES AND LEGISLATION TO PROMOTE FOREST CONSERVATION}

A knowledge of the history and development of forestry in the United States is necessary for proper understanding of the evolving of a national forest policy. Definite progress was made over a period of approximately fifty years before the present system of forestry came into being. Much discussion, deliberation, and legislation marked the development of federal forestry activities. Almost from the earliest colonial times, fears were expressed for the future of our forest resources. Until recently, little definite information has been available regarding our timber resources, and even at the present time an exhaustive survey is being conducted by the Forest Service to obtain more accurate knowledge of these resources. Although there were many and ineffectual attempts by the federal authorities to encourage forest conservation and growth usually for purposes of national defense, the year 1876 saw the first definite results of the attempt to formulate a federal forest policy. In 1876, Congress appropriated $\$ 2000$ to employ a competent man to investigate the timber conditions of the country and report upon them.

A program of federal legislation has been passed in the following sequence of events:

1876-First federal appropriation for forestry. Dr. Franklin B. Hough appointed with investigational and informational duties.

June 30, 1886-Division of Forestry created in the Department of the Interior. This marked the first definite recognition of the importance of the forest problem.

March 3, 1891-The President was authorized to establish forest reserves to be created from the public domain, and on March 3, 1891, the first federal reserve, known as the Yellowstone Park Timber Lands Reserve, was proclaimed by President Harrison. This was the beginning of our present National Forest system.

June 4, 1897-The present National Forest Act was passed, providing for the acquisition and administration of our National Forests, then known as Forest Reserves, under a definite, workable law.

June 1, 1901-The title, Division of Forestry, was changed to the Bureau of Forestry.

February 1, 1905-The Bureau of Forestry became the Forest Service, under Gifford Pinchot; and during the next few years under 
President Theodore Roosevelt, there was a great expansion in the area of National Forests created from the public domain in the Rocky Mountain and Pacific Coast States.

March 1, 1911-The Weeks Law was passed providing for the acquisition of National Forests in the East by purchase of forest properties on the headwaters of navigable streams. Heretofore our National Forests could only be created out of the public domain or unalienated lands belonging to the Federal Government. This act provided for the creation of the National Forest Reservation Commission and also for cooperative fire protection with the individual states in providing for an adequate system of fire prevention, detection, and suppression.

June 7, 1924-Clarke-McNary Bill signed by the President. In effect the President and Congress established on a statutory basis a fundamental forest policy for the United States. This provided for effective cooperation with the various states in forest-fire prevention and suppression, authorized a study of forest taxation, authorized cooperation with the various states in production and distribution of forest tree seeds and plants for reforestation purposes, provided assistance for the owners of woodlots in establishing, improving, and renewing them, and provided for increased purchases of National Forest lands and other miscellaneous purposes. Congress amended this act in 1931 to extend the provisions of the act to territories and island possessions.

March 22, 1928-The McSweeney-McNary Bill was passed, providing for a definite program of forest research.

April 30, 1928-The McNary-Woodruff Bill was passed, authorizing appropriations aggregating $\$ 8,000,000$ for the extension of the National Forests by purchase during the next three years.

November 12, 1930-President Hoover appointed the United States Timber Conservation Board which was formally organized in 1931. After considerable discussion the members of this board presented several conclusions and recommendations for the furtherance of a national forest policy.

1933-With the inauguration of President Franklin D. Roosevelt came a succession of presidential and congressional acts which had a very important bearing upon the development and progress of our federal forest activities. Among these may be mentioned the National Industrial Recovery Act, the Emergency Conservation Work, the Tennessee Valley Authority, and the Soil Conservation Service. All these are briefly described later in the text.

June, 1934 -President Roosevelt announced the Great Plains Shelterbelt Project, providing for the relief of unemployment and the protection of homesteads from the drying influences of severe winds by tree planting. This is also described later in the text. 


\section{LEADERS IN THE DEVELOPMENT OF AMERICAN FORESTRY}

Any constructive movement determining national development and policies naturally revolves around a relatively few men of thought and action. The development of forestry has been remarkably rapid, considering the nation-wide scope of the work to be done and the great variety of objectives in each locality and region. Many men with botanical, geological, or other scientific training and many publicspirited citizens were active in the early days of the movement. These men contributed very materially to the development of thought, the inspiring of general interest in the subject, and the crystallization of this sentiment in the form of laws. Among those who were chiefly responsible for the development of American forestry in the early days were Franklin B. Hough, first Chief Forester, and Gifford Pinchot, first professionally trained forester in this country, who after serving on the Biltmore estate in North Carolina, became Chief Forester in 1898 and later served under President Theodore Roosevelt. He was very influential in the organization and tremendous expansion of the work of the Forest Service. He was also instrumental in the formation of the Yale School of Forestry in 1900, the first permanently established professional school in the country. He later served two terms as governor of Pennsylvania.

Dr. B. E. Fernow was one of the early chief foresters of the old Division of Forestry, and in later years he served at the forestry schools at Cornell, Penn State, and Toronto. Professor Filibert Roth was an active and able leader in the government service and for many years was at the head of the forestry school at the University of Michigan. Dr. Carl Schenck, one of the first professional foresters, also served on the Biltmore estate in North Carolina; later, in 1898, he organized the Biltmore Forestry School, continuing as a lecturer at several American forestry schools.

The last three foresters received their professional training and preparation in Germany. They introduced into this country many of the ideals and standards and much of the inspiration of German forestry, and they contributed a marked influence on the early development of forestry as practiced in the United States.

Two presidents, Theodore Roosevelt and Franklin D. Roosevelt, have been outstanding in their contributions to the development of American forestry. The first was responsible for arousing real interest in forestry throughout the country, and provided for an enormous expansion of our areas in National Forests by setting aside a 
very large share of these areas from the public domain as provided for in the Act of 1891.

President Franklin D. Roosevelt has unquestionably made the most notable contribution of any single man in this country, and he was the first American to receive the Sir William Schlich medal for meritorious services in forestry. $\mathrm{He}$ is responsible for giving the people of the American nation a new understanding and appreciation of the value of our forests. In reconstructing and rebuilding our forests, both public and private, through the Civilian Conservation Corps, National Industrial Recovery Act, Soil Conservation Service, Tennessee Valley Authority, Public Domain Grazing Act, Great Plains Shelterbelt Project, enlarged acquisition policy for National Forests in the East, creation of the Natural Resources Board, and many other projects inaugurated in the first years of his administration, he has advanced the cause of forestry more substantially than any other one man.

Other men making notable contributions of thought, energy, and action have been: Col. Henry S. Graves, second Chief Forester of the United States, and organizer and dean of the Yale School of Forestry; Col. William B. Greeley, third Chief Forester of the United States and later secretary-manager of the West Coast Lumbermen's Association of Seattle; Charles Lathrop Pack of Lakewood, New Jersey, and his son, Arthur Newton Pack, of Princeton, New Jersey, both of the American Tree and Nature Associations, who have been active and effective in educating the public regarding the importance of forests and forestry; and George D. Pratt, active in the development of wild life and recreational forestry, and president of the American Forestry Association for several years. 


\section{CHAPTER III}

\section{FOREST RESOURCES; PRINCIPAL TREES AND REGIONS}

\section{GENERAL-FOREST REGIONS}

The commercial forests of the United States comprise about $25 \%$ of the total area of the country, or about $60 \%$ of the primeval forest area. Originally they occupied $822,238,000$ acres, or nearly one-half of the total land surface of the country.

Much of our forest is found at high elevations in the mountainous regions, conspicuously in the western states where the timber is relatively inaccessible, of insufficient size or of inferior quality to be of commercial importance for saw logs, pulpwood, or other forms of forest products. Forests in these locations are chiefly valuable for watershed protection and seldom enter commercial markets.

Many of our forests have been cleared for agricultural purposes, or burned, or are located in swamps. Under these conditions they are of little or no value in furnishing usable commodities.

The U. S. Forest Service has separated the American forests into eight broad major regions. They occur in natural geographic and topographic units and generally exhibit distinctive and similar problems. In some regions, notably in the East, similar types of forests are found in two or more regions. On the other hand, hardwoods are concentrated largely in the Mississippi delta, the southern Appalachians, and adjacent sections of the southeast region which is largely devoted to southern pine.

For the purpose of description and analysis, the forests have been divided into the following regions and subregions. Special attention is given to the Southeast and Pacific Coast regions because of their past and prospective importance as centers of forest industries and as sources of lumber production.

\section{Eastern Forest Regions.}

1. New England, embracing the five New England States.

2. Middle Atlantic States, embracing the five states of New York, Pennsylvania, New Jersey, Maryland, and Delaware. 


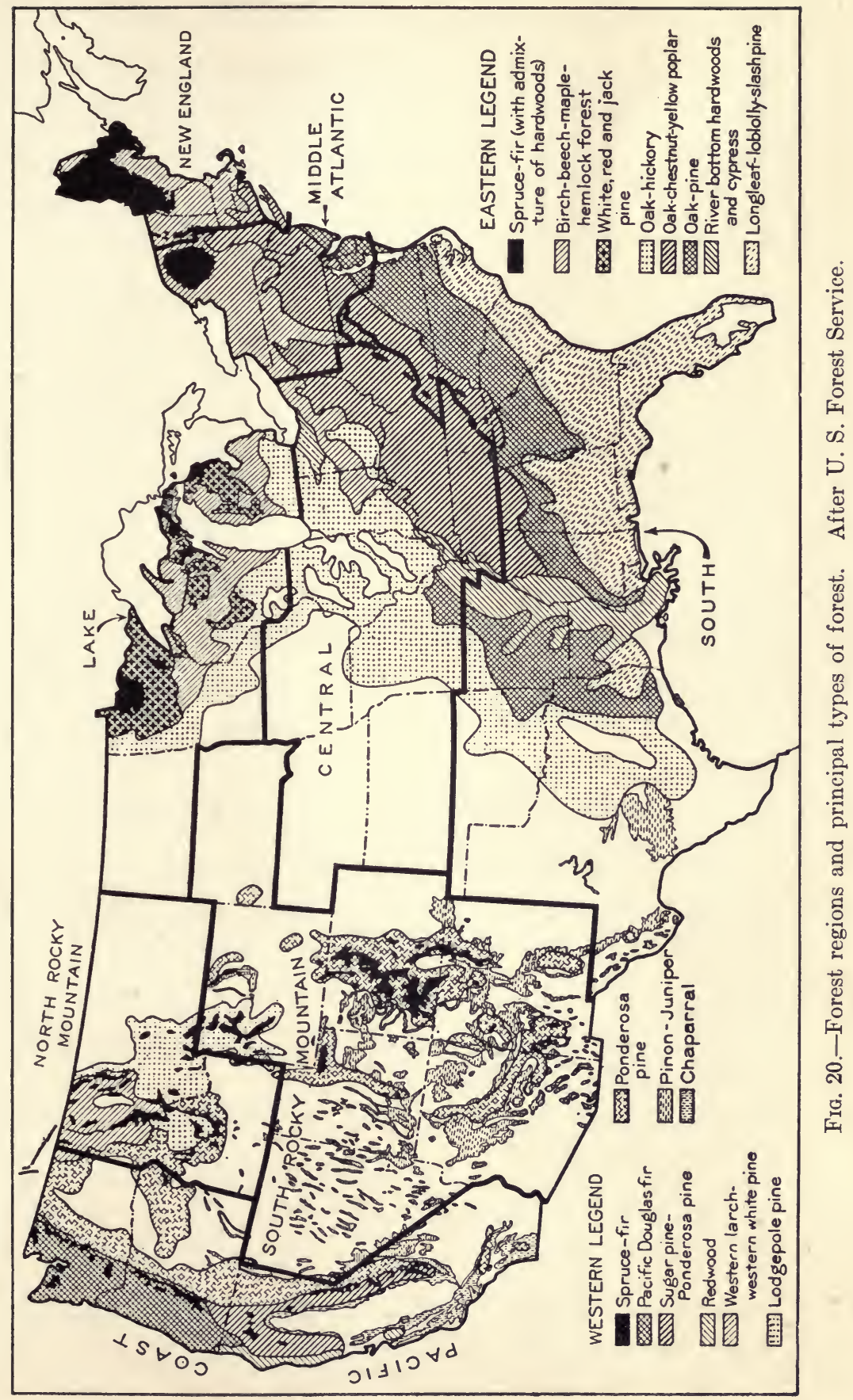


3. Lake States, embracing the states of Michigan, Wisconsin, and Minnesota.

4. Central States, including the eight central states from West Virginia to Missouri and Iowa, inclusive, and from Tennessee to Lake Michigan.

5. The Southeast, including the eleven South Atlantic and Gulf States from Virginia to Texas, inclusive, and Arkansas and Eastern Oklahoma.

Subregions:

(a) Southern pine from Florida to Arkansas and Texas, inclusive.

(b) North Carolina pine from Virginia to Georgia, inclusive.

(c) Appalachian hardwoods.

(d) Southern bottomland hardwoods.

(e) Cypress in Florida and in southern river bottoms.

\section{Western Forest Regions.}

6. Northern Rocky Mountain States, embracing Montana and Idaho.

7. Southern Rocky Mountain States, embracing Wyoming, Colorado, Utah, Arizona, New Mexico, and western South Dakota.

Subregions:

(a) Central Rocky Mountains of Wyoming, Colorado, Utah, and western South Dakota.

(b) Southwest, including New Mexico and Arizona.

8. The Pacific Coast region, including the three states of Washington, Oregon, and California and the Territory of Alaska.

\section{Subregions:}

(a) Northwest Douglas fir in Washington and Oregon west of the Cascade Mountains.

(b) Ponderosa pine in Oregon and Washington east of the Cascade Mountains.

(c) California pine.

(d) Redwood in northwestern California.

(e) Southeastern Alaska.

These regions have been arranged in geographical order from east to west and north to south. In order of importance, from the viewpoint of total forest area, they are arranged as follows: 


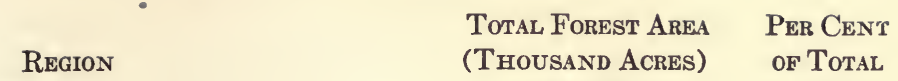

1. Southeast $\ldots \ldots \ldots \ldots \ldots \ldots \ldots \ldots \quad 191,739 \quad 38.7$

2. Pacific Coast .............. $66,685 \quad 13.4$

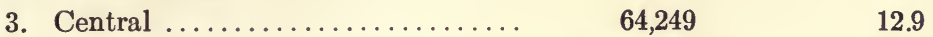

4. Lake States .............. $\quad 55,895 \quad 11.3$

5. Northern Rocky Mountains..... $\quad 32,329 \quad 6.5$

6. Southern Rocky Mountains..... $\quad 30,570 \quad 6.2$

7. New England ............ $27,273 \quad 5.5$

8. Middle Atlantic States . . . . $27,139 \quad 5.5$

Total for United States ..... $\overline{495,879} \quad \overline{100.0}$

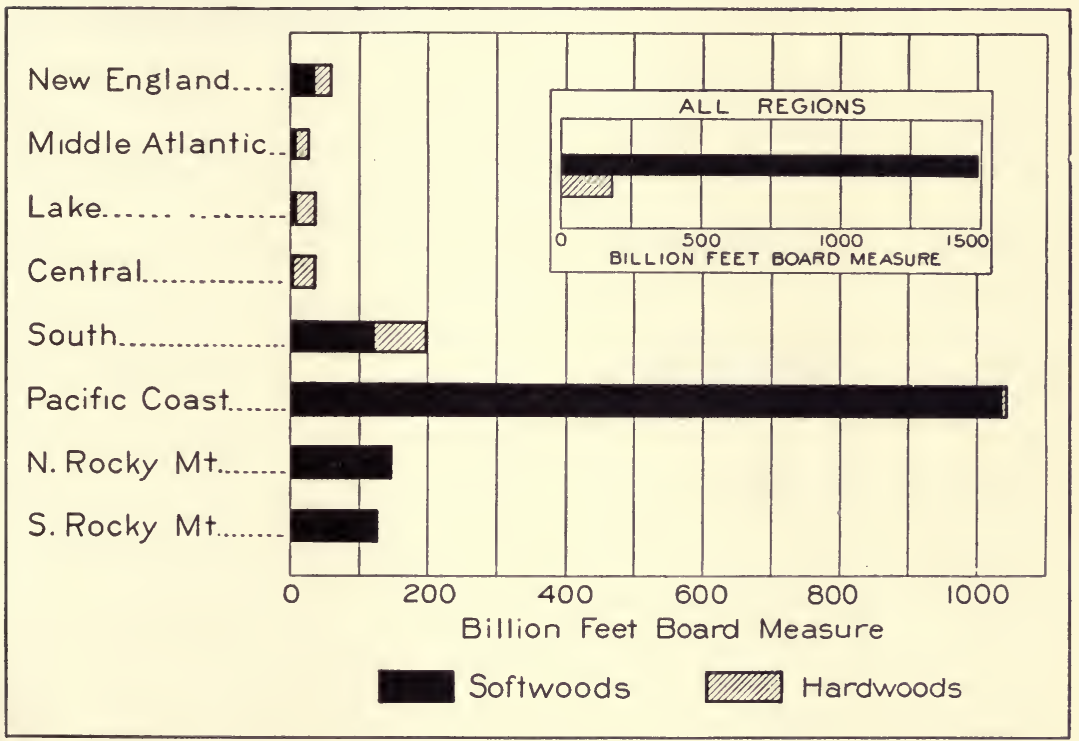

Fig. 21.-Softwood and hardwood saw timber stands of the United States by regions.

In order of importance from the viewpoint of total standing saw timber, they are arranged as follows:

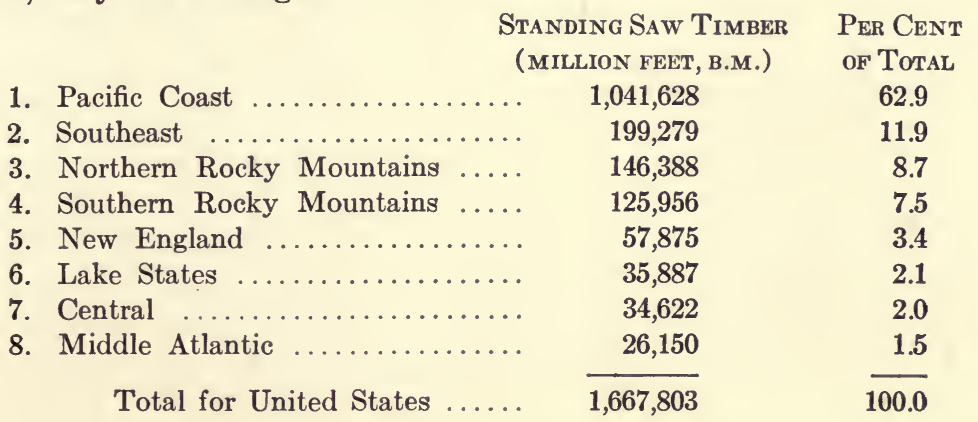




\section{AREAS}

The total forest area of the country is $495,879,000$ acres, of which only $188,645,000$ or about two-fifths contain merchantable saw timber. The balance of the forest area contains second growth of insufficient size to produce saw logs, also cordwood and miscellaneous young timber not at present of commercial utility.

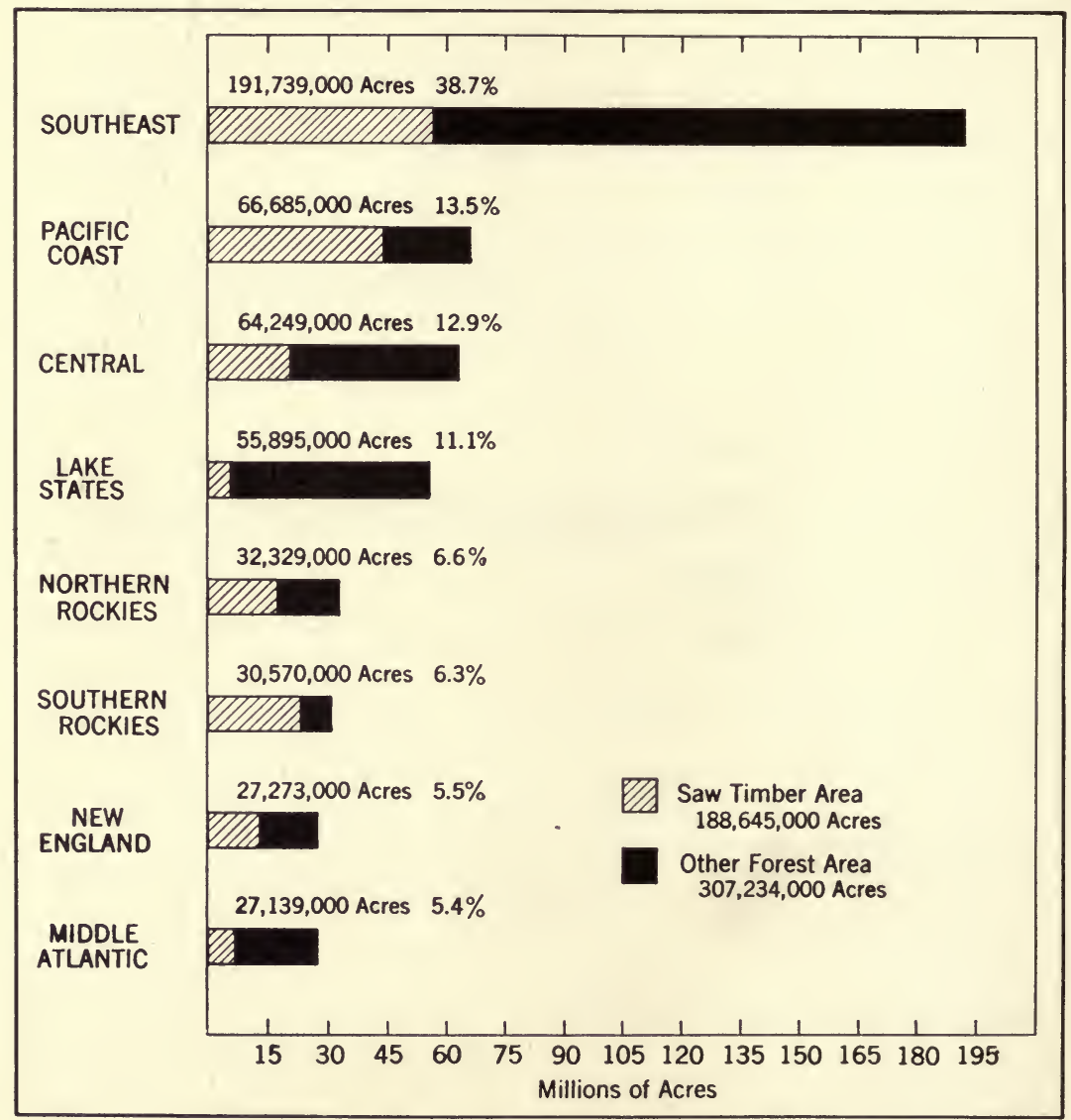

Fig. 22.-Commercial forest area of the United States by character of growth and regions. The total area is about 500 million acres of commercial forest.

Only about one-half the saw-timber area is virgin or old growth. The second-growth timber, especially in the South, however, is rapidly growing up to commercial size. Second-growth timber already plays an important part in the lumber markets of the country, as described elsewhere. 
About $39 \%$ of all our forest areas and over one-fourth of the sawtimber areas are found in the Southeastern forest region, including the so-called pineries, and contain about three times the area devoted to forests found in any other region. Only $26 \%$ of our forest area occurs west of the Great Plains, yet it contains the bulk of the volume of standing timber. Thirteen per cent of the total forest area of the country embraced within the Pacific Coast region contains $62 \%$ of all the saw timber left in the country.

Of the total area devoted to forests only about one-fifth or $98,855,000$ acres is of virgin or old growth. About $75 \%$ of this area is found west of the Great Plains.

\section{OWNERSHIP}

Ownership of our forests has been subdivided into three classes, namely: (1) private; (2) federal; and (3) state, county, and municipal.

1. Private Companies or Individuals Own $79 \%$ of Our Total Forest Area. These are chiefly lumbermen, farmers who own large areas of woodlots in small and scattered tracts, pulp and paper companies, and others interested in owning and holding forest properties. Most of the larger holdings controlled by private companies are found in the Pacific Coast region and in the South. Many of these companies own or control from 300,000 to several million acres of timberland.

2. Federal Agencies Own or Manage $18 \%$ of Our Forest Area. A large share of this area is in National Forests which are operated by the U. S. Forest Service, a relatively small percentage is controlled by the U. S. Indian Service and the National Park Service, War Department, etc. A very large percentage of these federally controlled forests is found in the Rocky Mountain and Pacific Coast States. In some states such as California, Idaho, Montana, and Oregon, a large share of the forest area is found within the National Forest boundaries. A small percentage of the National Forests is located in northern New England, the Lake States, the Southern Appalachian Mountains of the Southeast, and in Pennsylvania, Arkansas, and several southern states.

3. States, Counties, and Municipalities 0wn 3\%. There has been a pronounced forward move in the acquisition of forest areas by these agencies since the World War. More than thirty states now own or control forests. New York and Pennsylvania each have more than two million acres which are set aside in their state forests and parks.

Of the $188,645,000$ acres of saw timber, $126,265,000$ acres are owned 
by private individuals or interests; $59,277,000$ acres are owned and managed by federal agencies; and the balance, or only $3,103,000$, is owned by the states and local political units. It is apparent, therefore, that the private companies own the bulk of the remaining standing timber, both in area and in volume.

Public ownership (federal, state, county, etc.) embraces only $4 \%$ of all the forest land in the East, whereas in the West it includes $65 \%$.

As a large share of our forests is privately owned, logging methods have been pursued without any governmental supervision and con-

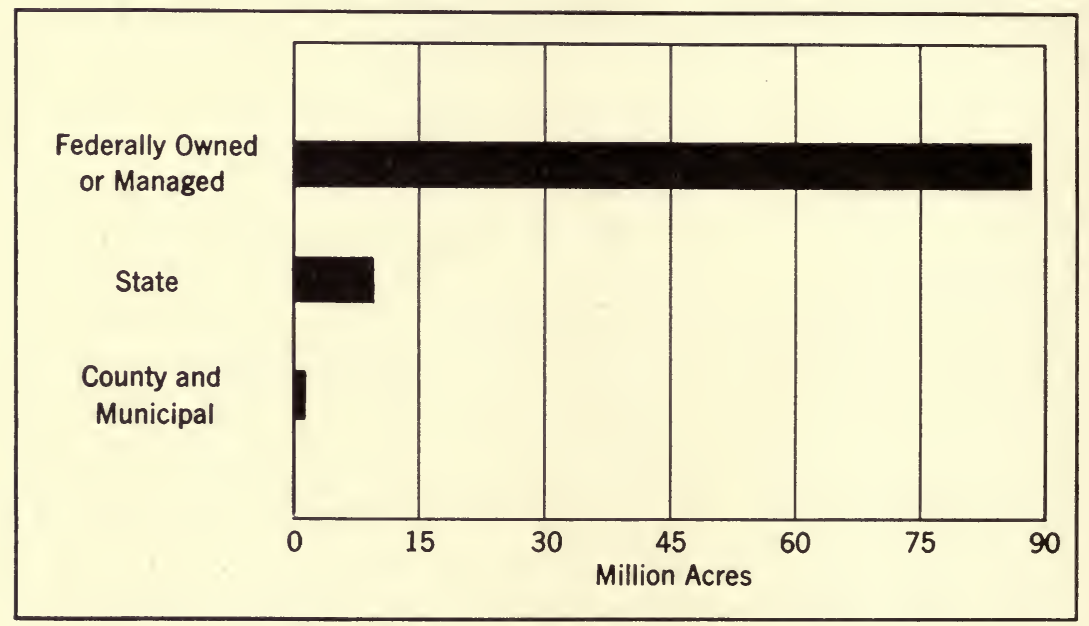

Fig. 23.-Graph showing public ownership of forest lands in this country. Only about $21 \%$ of our total forest area is so owned. Private ownership is represented in the balance or $79 \%$. Federal ownership is represented largely in the National Forests. There are also extensive forests in the National Parks, Indian Reservations and Military Reservations.

trol and, therefore, with little reference to the continuity of yield and the assurance of future cut adequate in either quantity or quality.

\section{VOLUME OF STANDING TIMBER}

The standing saw timber in the United States amounts to 1,667,$803,000,000$ b.f. or about one-third the original stand. Eighty per cent of the commercial saw timber is old or virgin-growth. The U. S. Forest Service estimated the standing timber in 1920 to be $2,214,-$ $893,000,000$ b.f.

Hardwoods and Softwoods. Eighty-nine per cent of the standing timber consists of softwoods and $11 \%$ of hardwoods. 
Eastern and Western Forests. The region west of the Great Plains contains $79 \%$ of all the remaining saw timber far removed from the great consuming markets of the nation. The three Pacific Coast

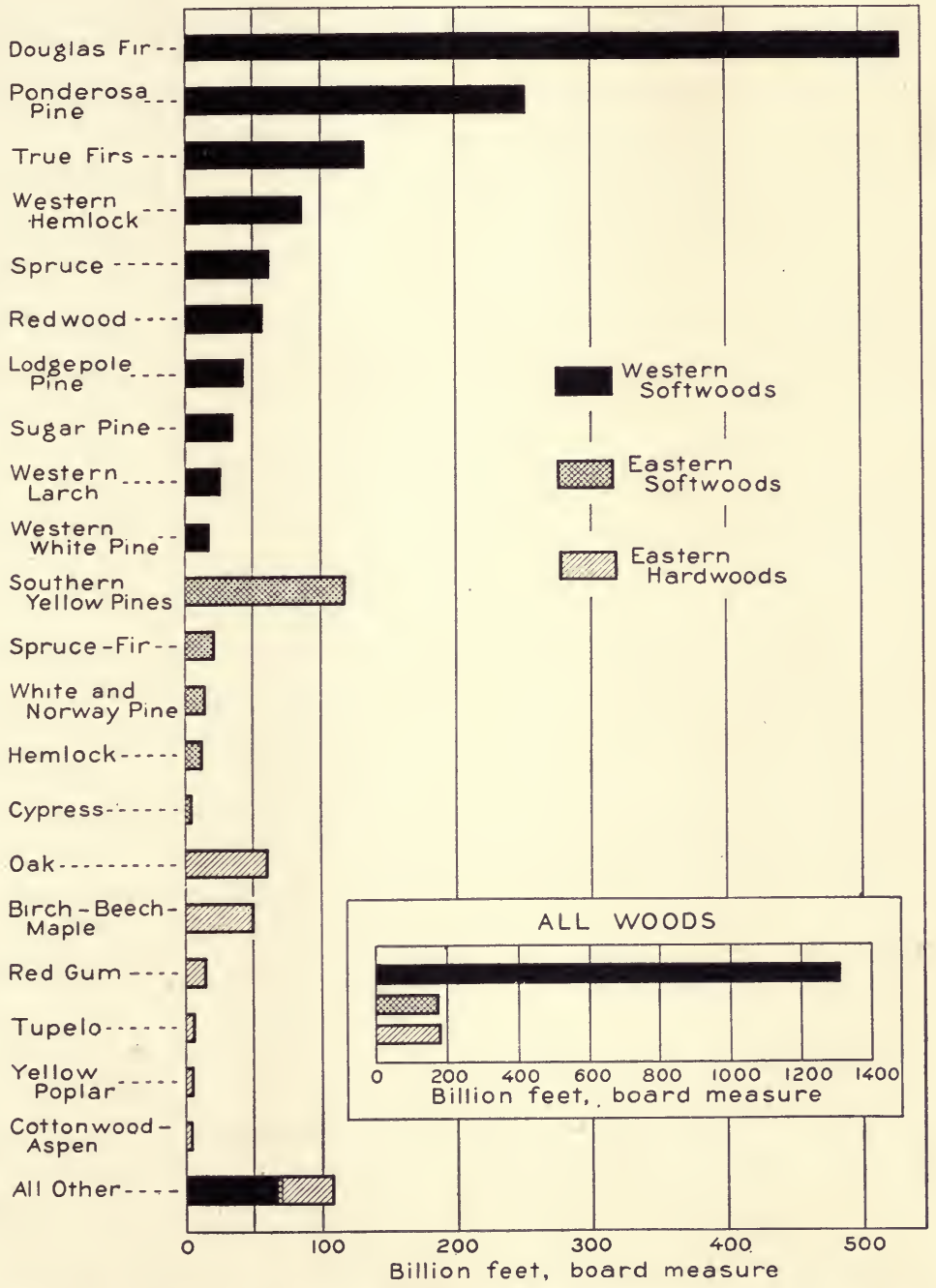

Fig. 24.-Saw-timber stand of the United States by important woods.

States alone contain $62 \%$ of all the saw timber. About $90 \%$ of the softwood saw timber is in the West and only $10 \%$ in the East.

The entire eastern forests contain only $21 \%$ of the standing saw timber. Lumbering and clearing for agricultural purposes have re- 
moved a very large portion of the once rich and varied forests of the region lying mainly east of the Mississippi River. In spite of the large areas devoted to forests in the Southeast, those states contain only $12 \%$ of the saw timber, but they possess an important and rapid growing second-growth forest which has great possibilities for the future.

Practically no hardwoods of large commercial importance are found in the Rocky Mountain or Pacific Coast States.

Character of Growth. Of the total stand of softwoods, $86 \%$ is of virgin or old growth, the large majority of which is found in the Pacific Coast States as noted above. Only about one-third of the hardwoods is of old or virgin growth and they are found largely in the Southeastern states with relatively small portions in the Lake States, New England, and Central States.

\section{LEADING COMMERCIAL SPECIES}

The leading species found in the saw-timber forests of the country are as follows:

\begin{tabular}{|c|c|c|}
\hline SPECIES & $\begin{array}{l}\text { Million Feet } \\
\text { Board Measure }\end{array}$ & Per Cent \\
\hline Total of all species & $1,667,803$ & 100.0 \\
\hline Douglas fir $\ldots \ldots \ldots \ldots \ldots \ldots \ldots$ & 530,197 & 31.8 \\
\hline Ponderosa pine $\ldots \ldots \ldots \ldots \ldots \ldots$ & 251,560 & 16.1 \\
\hline True firs $\ldots \ldots \ldots \ldots \ldots \ldots \ldots$ & 131,933 & 7.9 \\
\hline Southern yellow pine $\ldots \ldots \ldots \ldots \ldots$ & 118,132 & 7.0 \\
\hline Western hemlock ............... & 86,464 & 5.1 \\
\hline Western spruce $\ldots \ldots \ldots \ldots \ldots \ldots \ldots$ & 61,582 & 3.7 \\
\hline Oak $\ldots \ldots \ldots \ldots \ldots \ldots \ldots \ldots \ldots \ldots \ldots$ & 60,753 & 3.6 \\
\hline Redwood $\ldots \ldots \ldots \ldots \ldots \ldots \ldots \ldots$ & 57,233 & 3.4 \\
\hline Birch, beech, and maple ........... & 49,943 & 2.9 \\
\hline Lodgepole pine $\ldots \ldots \ldots \ldots \ldots \ldots \ldots$ & 43,276 & 2.6 \\
\hline Miscellaneous $\ldots \ldots \ldots \ldots \ldots \ldots \ldots$ & & 15.9 \\
\hline
\end{tabular}

Altogether about 60 commercially prominent species are found in the lumber markets of this country. Two species, Douglas fir and ponderosa pine, comprise nearly one-half $(46.9 \%)$ of all the standing timber. Many kinds of wood formerly regarded as of little value or even worthless have entered the lumber markets within recent years. Among these now assuming some prominence which formerly were considered either of inferior quality, rather difficult to season, or suffering by comparison with other valuable species, are western hemlock, tupelo and black gum, western larch, and even red gum and beech. Most of these woods have important intrinsic values and are now more favorably regarded in the lumber markets. Some of the 
true firs, aspens, and others have been of more recent recognition and acceptance on our markets. It is apparent from the above that one species, namely, Douglas fir, comprises nearly one-third of all the saw timber in the country, and nearly one-half of all the western softwoods. Oak is the leading hardwood species available in the American forests.

About 25 species (or groups of species as southern pine and the true firs) comprise $93.6 \%$ of the total stand of saw timber. Three species of softwood, namely, Douglas fir, ponderosa pine, and southern yellow pine, compose $54 \%$ of the total standing timber of the country. A brief description of the leading species is as follows:

1. Western Softwoods. Douglas fir is the most important tree from the viewpoint of standing timber, representing $31.8 \%$ of the remaining timber of the country. The center of production is Washington, but most of the standing timber of this species is found in Oregon. About $80 \%$ of the standing Douglas fir is found in the two states of Oregon and Washington, which produce about $95 \%$ of all the Douglas fir. This species, recently superseding in quantity southern pine, is the most important present source of construction lumber and timber. It reached its peak production of $10,411,000,000$ b.f. in 1926. It is shipped widely to both domestic and foreign markets. Large volumes are shipped to the Atlantic seaboard, via the Panama Canal, and to southern California. This tree grows both in pure stands as well as in mixed stands with western hemlock, western red cedar, and sometimes with Sitka spruce, the true firs, and others. It occurs over large areas west of the Cascade Mountains in the two states of Oregon and Washington and in British Columbia, and is widely distributed over most of the Rocky Mountain and Pacific Coast States.

Average stands over large areas are found containing from 30 to 60 m.b.f. per acre, and with an average of about 40 m.b.f. on extended areas within the commercial region in Washington and Oregon. Some stands are found with from 200 to $400 \mathrm{~m}$.b.f. on single acres. Individual trees have been found to produce up to 50 m.b.f.

Ponderosa pine is the most widely distributed pine in North America. It comprises $16.1 \%$ of all the remaining saw timber and has advanced rapidly in lumber production during the past several decades. Seventy per cent of this species is found in the three Pacific Coast States. It reaches its largest size both in diameter and height in California, but is produced chiefly in Oregon. These two states produce more than $60 \%$ of this species. It is the third most important 
kind of lumber found in our American markets. It is also cut to some extent in Washington and Idaho, and in all the western mountain states.

True Firs. These are chiefly white fir, Abies concolor, red fir, Abies magnifica, and noble fir, Abies nobilis. They are found principally in Washington, Oregon, and California in frequent mixture with Douglas fir and sugar pine, and occasionally ponderosa pine at the higher elevations. White fir entered the lumber markets prominently for the first time in 1929 when $307,000,000$ b.f. were reported by the Census Bureau. This species was exceeded in production by only six western softwoods. The true firs include $131,933,000,000$ b.f. of standing timber and are exceeded in volume of saw timber only by Douglas fir and ponderosa pine. They will probably enter the future lumber markets still more prominently because of the large available stands and the large size of the trees. At present they are used locally on the Pacific Coast for common and inexpensive forms of lumber and timber.

Western Hemlock. There are $86,464,000,000$ b.f. of saw timber of this species. It has recently entered the lumber markets in substantial volume. It is found almost entirely in Washington and Oregon and is a very prominent tree in British Columbia and the coastal section of southern Alaska. It enters the Atlantic Coast lumber trade where it is often sold interchangeably with Douglas fir and for the same general purposes. It is even preferred to fir for some uses. Formerly considered of little or no value, it is now logged commonly in most of the large operations of the North Pacific Coast.

Spruce. There are $61,582,000,000$ b.f. of spruce. Of this, 36,000 ,000,000 b.f. are chiefly Engelmann spruce in the Southern Rocky Mountain region, largely at high elevations in Colorado. There are about 12 billion b.f. of Sitka spruce, which reaches extremely large size along the Pacific Coast from Oregon to southern Alaska. It is frequently logged in both pure stands and in mixture with other species in western Oregon and western Washington. There are immense stands of this species in the Olympic Peninsula. There are over 12 billion b.f. of spruce in the Northern Rocky Mountains. This consists largely of Engelmann spruce in northern Idaho and western Montana. A small amount of blue spruce is found in the Southern Rocky Mountain region, chiefly in Colorado.

Redwood. In the narrow strip along the northern California coast, which extends into southwestern Oregon, $57,233,000,000$ b.f. of standing redwood saw timber is found. This consists of large trees up to 10 feet or more in diameter and 300 feet in height. There is suffi- 
cient redwood to last more than 100 years at a normal annual cutting rate, which has been about $500,000,000$ b.f.

Lodgepole Pine. This is one of the most widely distributed conifers in the West. It seldom reaches large size, trees occurring only up to 16 inches d.b.h. This size lends itself readily to cross tie and pole production. There are $43,276,000,000 \mathrm{~b}$.f. of lodgepole pine. It is found chiefly in the Southern Rocky Mountain region where over 26 billion b.f. occur; $14 \frac{1}{2} 2$ billion b.f. are in the Northern Rocky Mountain region and a little more than 2 billion b.f. in the Pacific Coast region.

Sugar Pine. This is the largest pine in the world, some specimens being found up to 10 to 12 feet in diameter and 250 or more feet in height. It is one of the most valuable species of white pine, producing a highgrade finish, pattern, and box lumber. It reaches its best development in the central Sierra Nevadas where stands occur up to 100,000 b.f. per acre. The good commercial timber varies from 20,000 to 40,000 b.f. per acre, with an average of about 30,000 b.f. Three hundred and forty-nine million board feet of sugar pine were produced in 1929 , and there is a total remaining stand of $35,516,000,000$ b.f., all of which is found in the

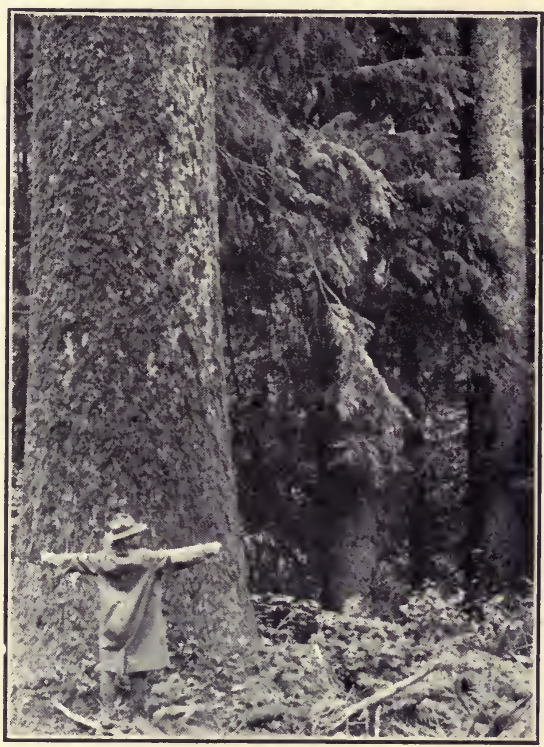

Fig. 25.-Sitka spruce 8 feet in diameter. This tree is usually found in association with western hemlock, Douglas fir and western red cedar and sometimes grows in pure stands. It is the source of much lumber used for airplane construction, boats, scaffold plank, box boards and many other materials. Pacific Coast region, chiefly in

California with a small amount extending into southern Oregon.

Western Larch. There are 26,118,000,000 b.f. of western larch chiefly in the Northern Rocky Mountain region of western Montana and northern Idaho. About 8 billion b.f. are found on the Pacific Coast region in Washington and Oregon. In 1930, 173,753,000 b.f. were cut. This produces a hard, heavy, durable wood which is used chiefly for construction purposes. It occurs in mixture with western white pine and ponderosa pine. Butt logs of larch will not float in 
stream driving; they are shaky and therefore are generally left in the woods.

Western White Pine. This is one of the most valuable trees in the country and is one of the three important white pines which are merchandised widely and used for high-grade finish, pattern, and box

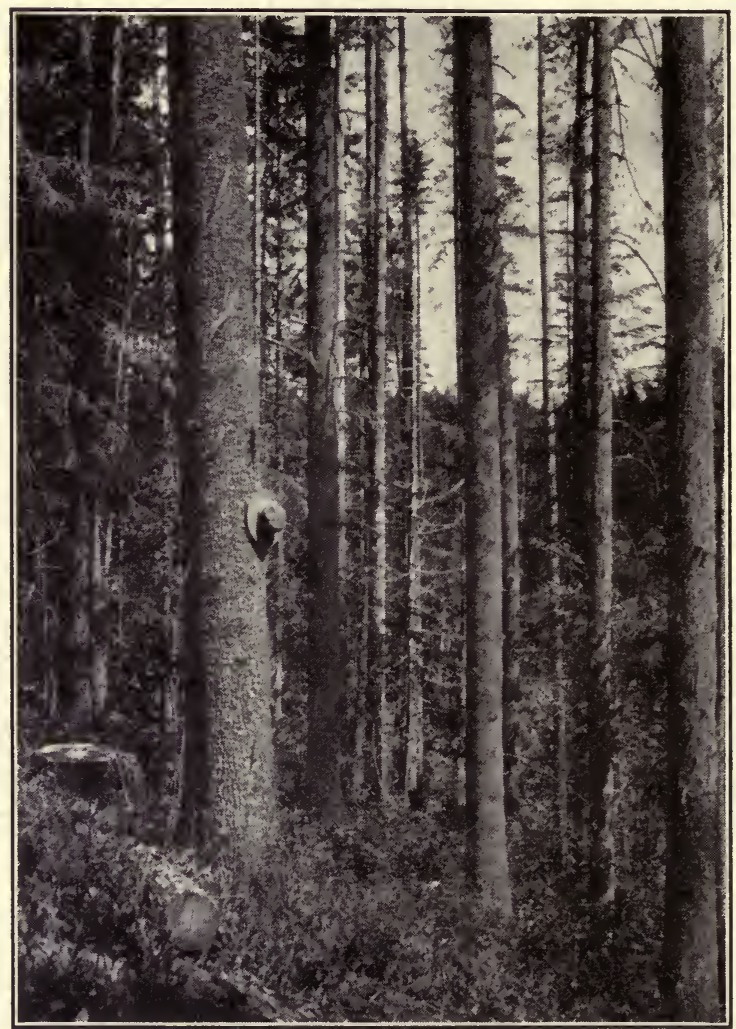

Fig. 26.-Typical example of thrifty western white pine left on timber sale area after cutting by the selective logging method from along the west branch of the Priest River in the Kaniksu National Forest in northern Idaho. Low stumps were cut and merchantable timber taken to $6^{\prime \prime}$ in the tops. Western white pine is one of the most valuable trees left in our American forests.

lumber. There are 19,508,000,000 b.f. of standing timber of this species, over 15 billion of which are found in the Northern Rocky Mountain region largely in northern Idaho and to some extent in northwestern Montana. About 4 billion b.f. are found in the Pacific Coast region, chiefly in Washington. Every year about $424,000,000$ b.f. of this species are normally cut. In the census figures it is tabulated with northern or eastern white pine. 
2. Eastern Softwoods. Southern yellow pine (including the four species of longleaf, shortleaf, loblolly, and slash pines) has been for thirty years or more the most important kind of lumber produced in this country. It is found widely scattered from eastern Texas to Virginia and from Arkansas to Florida. There are few remaining stands of virgin timber. They are found largely in Florida, Louisiana, and Arkansas. A large volume of southern pine known in the market as North Carolina pine, is still produced from the region extending from Georgia to Virginia, inclusive. There are $118,132,000,000$ b.f. of southern pine in the saw-timber stands. This is found almost entirely in the Southeast, but very small portions are found in the Central and Middle Atlantic regions as well. About 11/2/2 billion b.f. of southern pine were produced in 1929 and $71 / 2$ billion b.f. in 1930 . It reached its peak production with over 16 billion b.f. in 1907. More than half of the southern pine production now comes from the small mills.

Spruce and Fir. These are red spruce and balsam fir which are generally found and sold together. There are 21,533,000,000 b.f. in saw-timber stands. Nearly 19 billion b.f. of this amount are still found in the New England States, with small quantities in the Middle Atlantic and Lake States and along the higher Appalachian Mountains. They are cut almost entirely for pulpwood. On some operations, the butt and larger logs may be used for lumber and the balance for pulpwood. They are limited to the higher elevations in northern New England and the other regions, except in the Lake States where they are found chiefly in northern Michigan, northern Minnesota, and to a limited extent in northern Wisconsin.

White and Norway Pine. For many years white pine was the preeminent lumber tree of the country and is probably the most useful all-around species ever produced in our American forests. There are $14,672,000,000$ b.f. of white and Norway pine, most of which is second-growth. White pine forests occur in New England, where $8,390,000,000$ b.f. are found. Also small quantities are found in the Middle Atlantic and Lake States and along the higher Appalachian Mountains in the Central and Southeastern regions. It is found at the higher elevations only in the southern part of its range. It is cut largely in small mill operations. Its outlet is chiefly for box lumber and for local building construction.

Hemlock. There are 12,198,000,000 b.f. of hemlock which is widely distributed over the Northeast and Lake States. More than half of this quantity is found in the Lake States and New England regions. A smaller quantity is found in the other three eastern regions. It is 
practically all second-growth and cut on small operations except in Wisconsin where it is produced from a few large operations. It is preeminently used for small dimension and common lumber. It also finds an important outlet in pulp and paper manufacture, especially in Wisconsin.

Cypress. A large portion of the virgin cypress has been cut. There are $4,140,000,000$ b.f. of standing timber, a very large share of which is found in Florida where it is chiefly cut, and in the other southeastern states. A very small portion is found in the Central region. It is widely distributed throughout the lower Mississippi, Gulf, and south Atlantic coastal regions, where it is limited to the swamps and along streams. In 1930, 490 million b.f. were cut. It is one of the most valuable, durable, and useful species cut in the country and finds an outlet where durability, appearance, and workability are the chief requirements.

3. Eastern Hardwoods. Oak. Oak is cut from a large number of the 50 different species. It is widely distributed over the eastern and southern forests. There are $60,753,000,000$ b.f. of oak, mostly in the lower Mississippi valley section of the Southeast region where more than one-half of the oak occurs. The Central region contains over 16 billion b.f. Smaller quantities are found in the Lake, Middle Atlantic, and New England regions, the importance of the stands being indicated by the order of mention. Oak has always been the most important hardwood and finds a wide and ready market for specialized purposes, chiefly furniture, flooring, cross ties, automobile manufacture, tool handles, etc. It is produced chiefly in Tennessee, Louisiana, and Arkansas, named in order of importance. In 1930, 1,661,000,000 b.f. were sawed. All oaks are generally classified as either red or white oaks. White oak is generally considered the more valuable except in the southern Appalachian Mountains where red oak is the more valuable.

Birch, Beech, and Maple. These species are grouped together as they occur generally in association in the same stands in our northern and northeastern forests. There are $49,943,000,000$ b.f. of these species, about 21 billion b.f. of which occur in New England, about 3 billion in the Lake States, and small quantities in the other three eastern regions. Of these species, maple is the most important. In 1930, 601 million b.f. of maple were produced, 248 million b.f. of birch, and 138 million b.f. of beech.

Red Gum. There are 15,488,000,000 b.f. of red gum in our sawtimber stands. This is found growing throughout the Southeast region, largely in the lower Mississippi valley states. In 1930, 694,000,000 
b.f. were produced chiefly in Louisiana and Mississippi. An increasing volume is being produced from small mills. It is frequently sawed in small mills in connection with the production of yellow pine.

Tupelo. There are $6,342,000,000$ b.f. of tupelo gum, practically all of which is found in the Southeast in swamps and along the estuaries

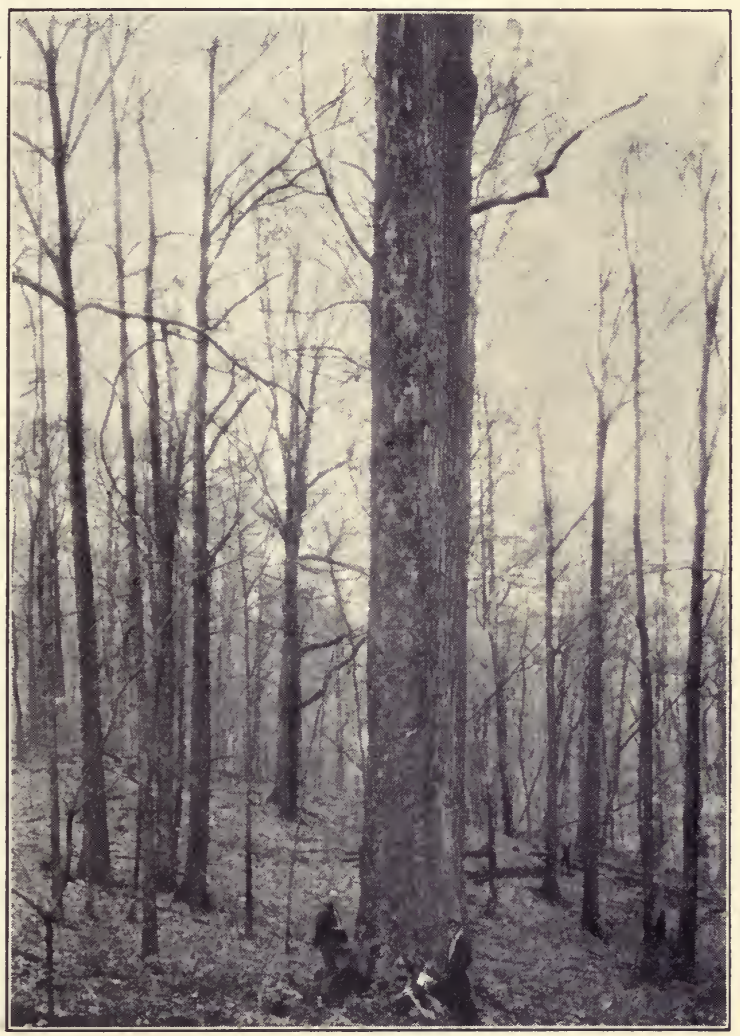

Fia. 27.-Old growth yellow poplar 69 inches in breast high diameter. This tree was "curly" grained and contained 9,000 feet of merchantable material. The seeking out and logging of such scattered high value special timber has been one of the most interesting phases of the lumber industry in the Appalachian Mountain region. Towns County, Georgia.

and bays of the streams flowing to the south Atlantic and Gulf Coast. It is produced chiefly in Louisiana. In 1930, 254 million b.f. were produced. It is logged in connection with other hardwood species. Formerly considered somewhat undesirable, it now reaches important markets.

Yellow Poplar. There are 5,192,000,000 b.f. of yellow poplar, most 
of which is found in mixture with other hardwood species along the stream bottoms of the Southeastern region. It is also found in all the other eastern sections. In 1930, 257 million b.f. were produced, mostly from West Virginia, Tennessee, and Alabama, in order of importance. This is the largest hardwood tree now found in our American forests. It produces a high-quality lumber and a large percentage of upper grades. Other species such as magnolia and cucumber are cut and sold as yellow poplar.

Cottonwood and Aspen. There are 4,447,000,000 b.f. of these species, including southern cottonwood, swamp cottonwood, aspen or popple, balsam poplar, and black cottonwood of the West. Of all these species, a large proportion is found in Minnesota where 61 million b.f. were produced in 1930, and in Mississippi where 29 million b.f. were produced that year.

Among the hardwoods produced east of the Great Plains which are relatively unimportant as compared with the above in quantity are ash, basswood, chestnut, elm, magnolia, black walnut, hickory, sycamore, butternut, black cherry, locust, hackberry, willow, and several others.

\section{PRINCIPAL PRODUCTS OF THE FOREST; GROWTH AND DEPLETION}

According to a report * prepared by the Forest Service, the current annual growth of usable material on commercial forest areas of the country amounted to $8,912,000,000$ cubic feet of saw timber and cordwood growth. More than half of the saw-timber growth and also of the total forest growth is in the South, which has more than half of its forest area or about $100,000,000$ acres in saw timber and cordwood.

Much of the forests of the West, particularly on the Pacific Coast, is composed of over-mature timber which is making little or no net growth.

The total timber cut, including lumber, fuelwood, and other forms of forest products, amounted to $14,495,308,000$ cubic feet, thus exceeding the current annual growth as approximately 14 to 8 . However, the estimate of the Forest Service as applied to timber cut was based upon an average for the five years 1925 to 1929 , inclusive, which more nearly represents a maximum of wood consumption than an average over a long period of years. For example, the average production of lumber shown by the Forest Service for these five years was 38 billion

* From "A National Plan for American Forestry," Senate Document 12, Washington, D. C., 1933. 


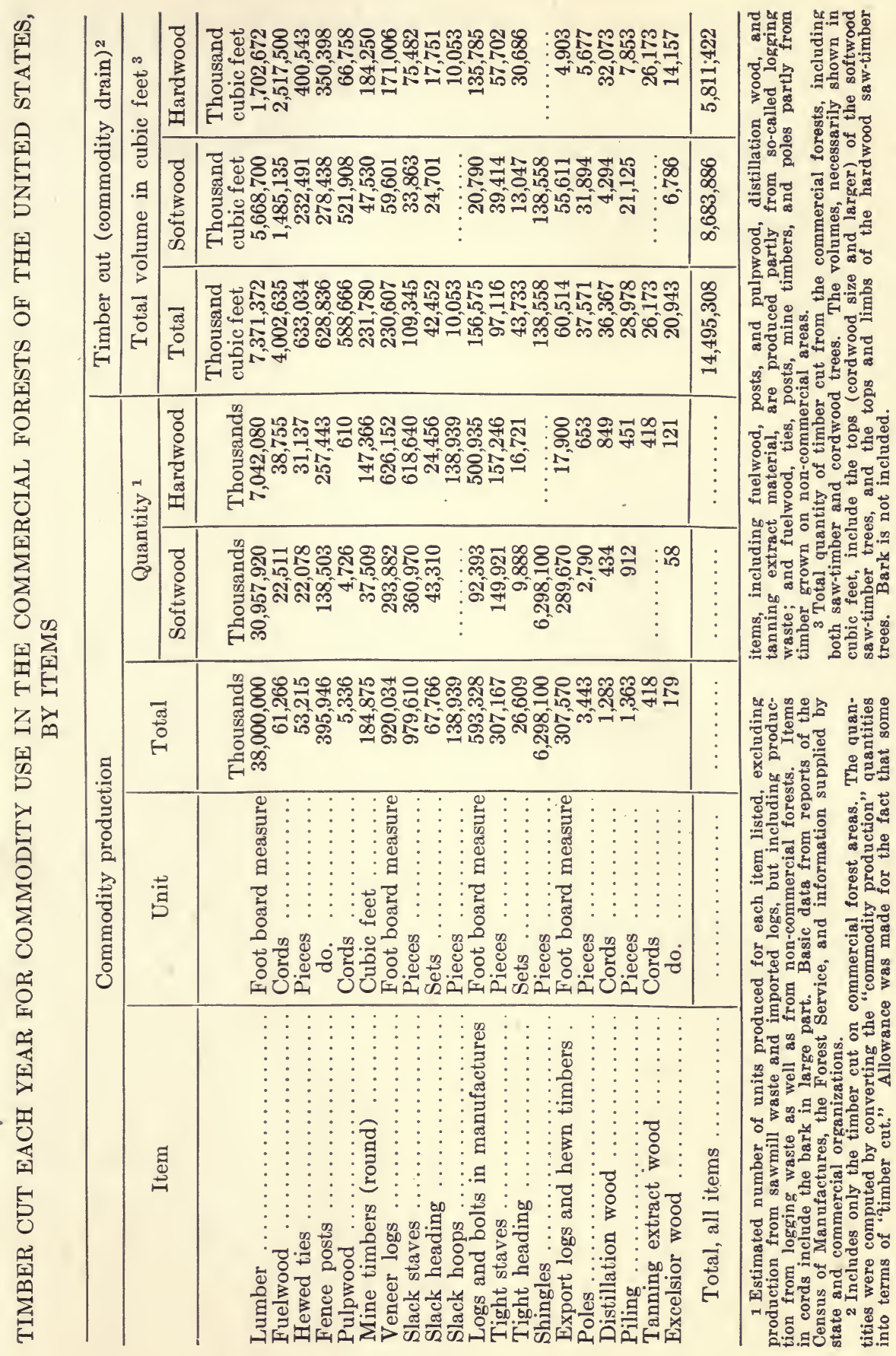


b.f., whereas lumber production fell off in 1932 to about 10 billion b.f. or $26 \%$ of the average, and no doubt other forms of forest products decreased more or less proportionately. Furthermore, growth is con-

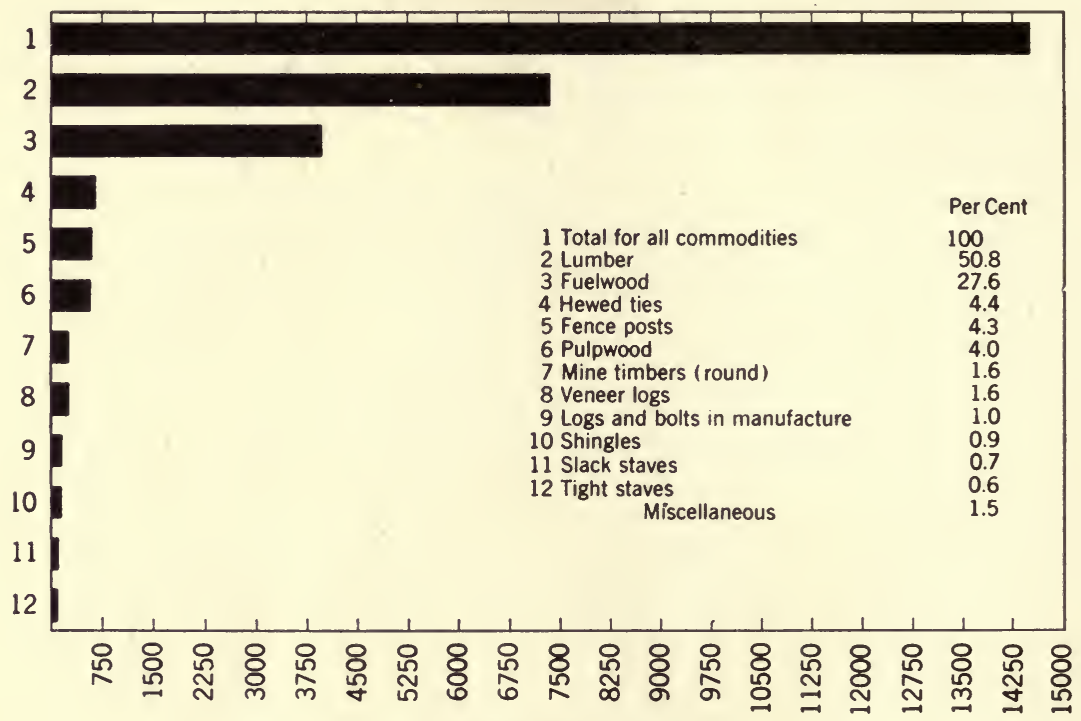

Millions of Cubic Feet

FIG. 28.-Graph showing the normal consumption of forest products by principal commodities.

stant or increasing in volume whereas the trend of per capita consumption of forest products has for several years been downward.

The table on p. 51 shows the amount of timber cut expressed in the units customarily used for each form of forest product as well as converted to a cubic foot basis based upon an average for the five years 1925 to 1929 , inclusive. 
FORESTRY TECHNIQUE AND MEASURES TO ACCOMPLISH A RATIONAL POLICY OF FOREST MANAGEMENT

\section{CHAPTER IV}

\section{THE TREE AND ITS CHARACTERISTICS}

\section{DEFINITION}

There are several definitions of a tree, but none of them is generally accepted in either scientific or professional circles. According to Harlow, ${ }^{*}$ a tree is a woody plant, at least 20 feet high at maturity, with a single stem or trunk and a definite crown shape. This definition seems to serve the purpose as well as any. In extremely windy locations, at high altitudes, near timber line and in far northern climates, trees seldom reach 20 feet in height. The same kinds of trees, under favorable or optimum conditions, may reach a height of 100 to 200 feet or more and up to several feet in diameter. Trees are the highest expression of plant life. The largest trees in the world are found in California, where the big tree, or giant sequoia, reaches an extreme diameter of $361 / 2$ feet (the General Sherman tree in Sequoia National Park). The largest pines in the world are also in California, the sugar pine being found recently up to $9^{\prime} 6^{\prime \prime}$ d.b.h. and containing 13 logs and 33,390 b.f. or much more than most of the merchantable acres of forest in the East contain.

Descriptive names are applied to trees of various size, height, and diameter. Although there are many varieties, trees may be classified for study and functioning in the practice of forestry according to height and diameter as follows:

1. Seedlings up to 3 feet in height.

2. Saplings from 3 feet in height to 4 inches in diameter at $4 \frac{1}{2}$ feet above ground.

3. Poles from 4 inches to 12 inches in diameter at $4 \frac{1}{2}$ feet above ground.

* Dr. W. M. Harlow, New York State College of Forestry, Syracuse, New York. 
4. Standards from 1 foot to 2 feet in diameter at $4 \frac{1}{2}$ feet above ground.

5. Veterans over 2 feet in diameter at $4 \frac{1}{2}$ feet above ground.

\section{HOW A TREE FUNCTIONS}

A tree is a living organism, complex in its structure, and not entirely understood as yet as to its functions.

A tree has three parts, each of which performs @ distinct function in its life. They may be described as follows:

1. The roots furnish water and nourishment and hold the tree in place against the elements of nature, such as wind, storms, ice, and snow. The older roots are most useful in holding the tree in place. The young roots or tendrils have the power of assimilating and taking up water and nourishment. The root system of a tree is generally within 3 to 5 feet of the top soil and in young trees within 1 or 2 feet. In early life, some trees have taproots as in oaks and walnuts, but none of the trees in later life have a deep taproot which enters many feet into the earth. A well-developed root system is very important in planting-even more important than the crown. Why

2. The stem, known also as the trunk or bole, furnishes wood for mankind, conducts water and food to the leaves, and provides support to the crown. The main trunk consists of bark, sapwood, and heartwood. Bark serves as a protective cover to the cambium layer which is found between the inner bark and the sapwood. This is the region of expansion and growth. A new layer of wood is added each year. Sapwood is the living portion of the wood next to the bark. It contains considerable plant food and has a higher moisture content than the heartwood. It is more susceptible to insect and fungus attacks and generally is lighter in color and weight. The heartwood forms the center of the trunk and usually a very large proportion of it except in young trees. It is physiologically dead and performs only the function of support. It is much harder, darker in color, more durable, and ordinarily more valuable than the sapwood.

3. The crown consists of the branches, twigs, leaves, flowers, and fruit. The leaves serve the tree as the lungs do men. Carbon dioxide in the air enters the leaves and, under the action of light, air, and water, performs certain life functions resulting in the formation of the annual layer of wood on the trunk, roots, and branches. Oxygen is given off from the leaves, and the carbon is retained. This combined with water obtained from the roots forms starch, sugar, gum, and 
other plant foods. This process of tree growth is known as assimilation. If the foliage is removed or light is not provided, the tree will weaken and gradually die. The flow of sap in trees is not entirely understood. In general, the sapwood conducts the water from the roots to the leaves where the assimilation process goes on and much of the water is evaporated in the air. Some acres of forests may take annually from the soil and give up to the leaves from 500,000 to $1,500,000$ pounds of water. Leaves of deciduous trees transpire one-sixth to one-third as much water as an equal surface of water. Coniferous trees transpire less than one-sixth as much as deciduous trees. (For further explanation, see any good textbook on botany.)

do Lens vale

The falling leaves in the autumn furnish nourishment to the soil and consistently build up and maintain its fertility., Therefore, leaves should not be burned in surface fires. Some trees, such as black walnut, yellow poplar, hard maple, and bass-

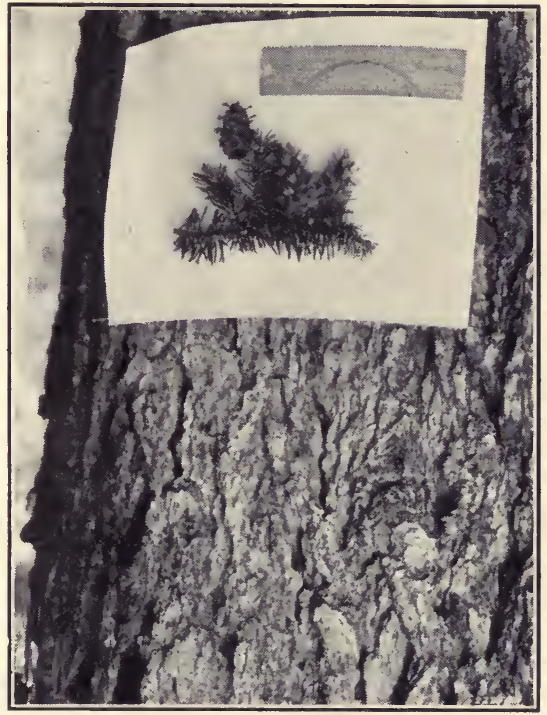

Fia. 29.-Douglas Fir (Pseudotsuga taxifolia)—bark, leaves, and cones. wood, require the finest type of fertile soils to attain the best development. Beech is known as the mother of the forest in Europe, as it furnishes leaves which add much to the fertility of the soil.

\section{CHARACTERISTICS OF TREE GROWTH}

Trees may be classified as to crown dominance, or the position of the crown in the canopy of a forest, as follows:

1. Dominant-the tallest and largest crowns in the canopy.

2. Co-dominant-those slightly below the dominant crowns.

3. Intermediate-those occupying a middle position in the crown canopy.

4. Overtopped-those which have been surpassed in the struggle to reach the upper part of the canopy and have been crowded out. 
5. Dead-those which have been so shaded in the struggle for light and competition for soil moisture that they have failed to receive sufficient sustenance to continue living. Overtopped trees may gradually die in the struggle for existence. Suppressed and dead trees are sometimes placed in the same class.

Trees may also be classified as to age, generally in 20-year periods. If all the trees in a forest are within an age class of 20 years, the forest is said to be even-aged. Trees should be cut when financially rather than physiologically mature if forestry is being conducted as a business. Some trees, such as poplars, aspens, and cottonwoods, are relatively short lived and mature, physiologically, at 50 to 80 years. Oaks may grow to be 500 to 1500 years of age; the giant sequoias may be from 2000 to 3000 years old.

Trees are generally managed on rotations of 20 to 100 years or more, but rotations of 20 to 40 years are applied to pulpwood, fuelwood, chemical or distillation wood, posts, grape stakes, etc.; from 40 to 60 years for cross ties, poles, piling, etc.; and 50 to 80 years or more for saw logs, cooperage bolts, and other special purposes. Willows are grown on one-year rotations for basket-ware.

\section{VARIETIES OF TREES}

According to the Forest Service, there are 862 separate native tree species in the United States. Including all the varieties and hybrids, 1177 are recognized by authorities. Many genera are indigenous only to the United States, such as hickory, redwood, persimmon, and some others. Some genera include many species; for example, there are 50 different kinds of oaks, 34 pines, 10 firs, and 7 spruces. Probably the greatest variety of useful trees to be found anywhere in the world occurs natively in the American forests.

Only about 60 species or groups, such as southern pine, reach commercial importance, and only 5 comprise about $90 \%$ of all the lumber cut annually.

Trees may be grouped into two broad divisions on the basis of both botanic and use factors. This classification, however, is generally used by botanists as well as foresters.

1. Broadleaf, deciduous, or hardwood trees, such as the oaks, birches, maples, gums, hickories, ashes, poplars, cottonwoods, elms, etc.

2. Evergreen, needle-leaf, or softwood trees, as the pines, spruces, firs, cypress, redwood, cedars, hemlock, etc. 
There are some notable exceptions to this classification because some softwoods as larch and cypress are deciduous and drop their leaves in the autumn. Some hardwoods, such as live-oak, holly, cucumber, etc., are evergreen and retain their green foliage through the winter season. Some of the hardwoods produce wood that is much softer than some of the softwoods, and vice versa, although generally the hardwoods produce wood that is much heavier, harder, stronger, and more durable than the softwoods. The softwoods are chiefly used for construction purposes and form about four-fifths of all our timber supplies. The hardwoods are used for much more specialized purposes as furniture, automobile parts, tools, handles, machinery, flooring, etc.

\section{HOW TREES GROW AND REPRODUCE}

Trees grow in height and diameter, and therefore in volume, by adding an annual layer of wood. Trees are actually made up of successive cones, each representing a year's growth, and

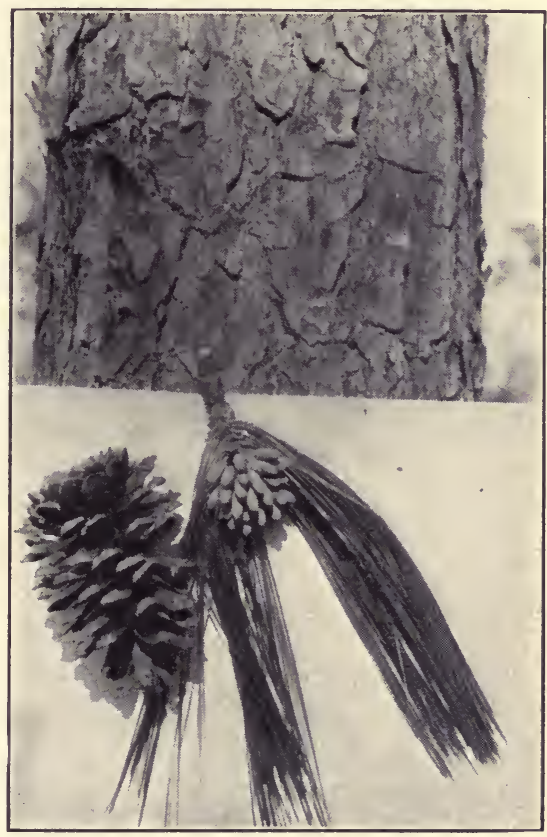

FIg. 30.-Bark, cones, needles and pollen cones of longleaf pine (Pinus palustris). one being laid literally on top of and outside the other. Annual layers of wood are sharply defined in temperate and northerly climates, whereas there is no definition in tropical climates because trees grow throughout the year. A large portion of growth under our conditions is generally added during the first few months of the growing season. During cold weather, trees are dormant. The growing season may be only from 2 to 3 months in duration or less in northern climates and at high altitudes, whereas it may be from 5 to 10 months or more in the warmer climates and at the lower elevations.

There is a definite relationship between altitude and longitude. For example, Douglas fir is found at low altitudes along the coast of British Columbia whereas it is found only at the highest elevations at the extreme upper limits of timber growth near timber line in the 
higher mountains and plateaus of Arizona and New Mexico. Spruce which occurs at sea-level in the Northeast and eastern Canada is found only on the highest elevations in the southern Appalachian Mountains.

The annular ring is generally separated into two distinct parts, namely, springwood and summerwood. The former is light in weight and coarse in texture compared with the darker, denser summerwood.

Trees depend for growth upon:

1. Moisture. Trees vary widely in their moisture requirements. Water is necessary for the assimilation of food elements. Some trees are water-loving or water-enduring, as cypress, willow, tupelo, water hickories, and water oaks; others require dry or well-drained soils. Hemlock and redwood thrive in moist, damp atmospheric conditions.

2. Light is indispensable. It is said that trees literally convert sunlight into wood. Light supplies the energy for the assimilation of food. However, trees vary in their light requirements. Some trees are tolerant of shade and will thrive under the canopy of other trees, for example, spruce, beech, and hemlock. Others are known as intolerant, such as ponderosa pine, longleaf pine, and yellow poplar. Many trees are intermediate as to tolerance. Site and moisture conditions have an important bearing upon their tolerance. The difference in tolerance is an important consideration in cultural thinnings, reproduction, and other phases of forest management.

3. Temperature. A certain amount of heat is necessary for all plant life. Trees cannot be transplanted successfully from warm to cold climates, or vice versa. Each species has its optimum climate and range of temperature in which it grows best. Exotic trees should be grown in conditions similar to their native habitat.

4. Soil. Soils have an important bearing upon tree growth. Trees are usually stunted, crooked, and slow in growth in thin, rocky soils, and conversely, thrive and exhibit the greatest health and vigor and best form in good soils. Hardwoods require much better soils than conifers. Soils and climatic conditions are usually unfavorable in the higher mountains and therefore conifers are generally present. In the rich agricultural sections, as in Ohio and Indiana, which have been largely cleared for agricultural purposes, our finest and largest hardwoods were found in the virgin forests.

5. Oxygen. Oxygen is necessary for all forms of plant life. Various chemical substances found in the air in addition to oxygen contribute to the growth of tree life. 
Trees are reproduced by the following methods. Reproduction is important because it forms the basis of succession of tree crops in forest management.

1. By seed. All trees bear seed in some form: the oaks, in the form of acorns; some, such as hickory and walnut, in the form of nuts; some, like the elm and maple, in the form of winged seeds. Seed is also developed in cones, as in the spruce, pine, fir, etc. In many parts of Europe, seeds, as those of the beech, furnish food for swine. Some forests are managed entirely for their nut crops, as in Italy and Turkey. The seed of the piñon pine was an important part of the food supply for the Indians in the Southwest. Tree seeds vary widely in their viability and germinative qualities.

2. By sprouts, known also as coppice. This is typical of hardwoods. When cut, hardwoods sprout promptly from the root collar or top of the stump. This is an important factor in the management of coppice forests. Redwood is a unique example of conifers which sprout successfully.

3. By cuttings. Some trees, such as willows, poplars, and cottonwoods, may be reproduced by making cuttings which, when planted under favorable conditions, will develop into live trees.

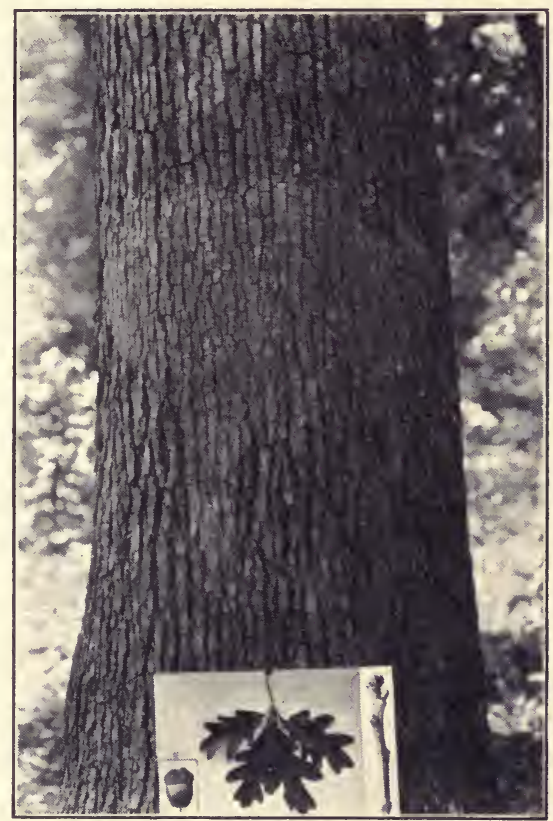

Fig. 31.-White oak (Quercus alba) as found in the forests of Virginia. Showing bark characteristics, leaves, flowers, acorn and twig. This species is found throughout the eastern part of the United States.

4. By suckers from the root system. Some shallow-rooted species, like beech, may send out large numbers of root suckers to reproduce the forest.

5. By layers in which branches lying on the ground may produce roots and develop into separate trees. Examples of this are Sitka spruce and red spruce. This is of very little practical importance. 
Although all the above methods may be used in regenerating the forest, a very large percentage is accomplished by seed. Trees generally reproduce themselves by natural processes, that is, by seeds germinating in the soil after falling from the parent tree. Many millions of seeds are produced for relatively few trees which may result from them. Seed is collected in enormous quantities for artificial reproduction, generally known as tree planting or reforestation. 


\section{CHAPTER V}

\section{FOREST INFLUENCES}

\section{THE FOREST AS A COMMUNITY OF TREES}

The forest, known also as woodland, woodlot, timber, timberland, etc., is not only an assemblage of trees. It is a living, organic, biological group, the units of which (trees) are constantly assisting each other against natural elements and are in constant competition for light (literally a place in the sun), moisture, and food. As a result of this struggle, the weaker specimens may be suppressed and die; the stronger trees will survive. In a planted forest where trees are spaced 6 by 6 feet apart, there are 1210 trees per acre. When mature or merchantable, only 100 to 400 trees per acre may remain in the stand. In open fields or on logged or burned areas, thousands, often hundreds of thousands, of seedlings naturally reproduced may be found. When this struggle is too severe, most of the trees may suffer and show slow growth and poor condition. This is why thinnings are so necessary. If too open, the wood goes into the branches rather than the main stem and height growth is not stimulated as in closed stands.

A stand must be kept fully stocked for most efficient results. A stand too open may develop little valuable wood, whereas one too dense may be a very destructive forest.

\section{SILVICS OR FOREST ECOLOGY}

Silvics, also called forest ecology, which is the relation of the forest to its environment, is the foundation of silviculture. Fundamental knowledge of silvics is essential for a proper understanding of silvicultural processes. It is of great importance in understanding the fundamentals and best methods of cultural thinnings and of reproducing the forest naturally and artificially. It is likewise of great importance in the prediction of future yields and in the preparation of plans for forest management. The life history of individual species, or ontogeny, must be clearly comprehended in order properly to understand the development of tree associations which are the basis 
of forest types. Forest ecology deals with the influence and interrelation of the environmental factors of soil, climate, light, and such contributing factors as other plant life, animal life, topography, site, and atmospheric phenomena. These influences and factors are not the same for any two species or groups of species because of different responses and reactions to the factors of environment. There is constant competition among the various species for the light above and for food in the soil. A site which may be most favorable for one species may be a mediocre or poor location for another species. Soil conditions are constantly in a state of improvement or deterioration. Artificial or natural conditions may modify these soil factors. All these environmental influences affecting the quality of the site are known as the site factors. The very range and distribution of forest trees may be changing. Forest conditions are practically never in a state of equilibrium or stabilization. The study of silvics and forest ecology constitutes one of the most important fundamental fields in the broad subject of forestry.

\section{INFLUENCE OF FOREST ON ITS ENVIRONMENT}

The two major effects of forest on environment are in relation to climate and soil. Forests also exert a great influence on the social and economic life of mankind which is discussed elsewhere.

1. Climate. It has not yet been definitely determined whether the forest has an influence on the climate over large areas or regions. However, it has been proved that the forest has a pronounced effect on the local climate. The temperature within the forest is subject to much less fluctuation than that in the open. The greatest influence of the forest on air temperature is experienced in warm regions. Hardwood forests exert a greater influence in the summer than softwoods and have far less effect in the winter on account of the dense foliage in the summer and their leafless condition in the winter. Forests or rows of trees break the effect of the wind. The influence of a shelterbelt may, according to Bates, be appreciable to the windward for a distance equal to five times the height of the windbreak and to the leeward for a distance of fifteen to twenty times the height. Windbreaks may in extreme cases save $70 \%$ of the moisture lost by evaporation.

2. Soil. The soil temperature is affected by the forest in the same way as the air temperature but to a greater degree. Much less frost heaving is found inside the forest than outside. Forest vegetation reduces the surface runoff and increases the amount of water that 
percolates into the soil. Forests are therefore of vast importance for the prevention of floods and the protection of watersheds. Forests hold the soil and protect it from being eroded into rivers and streams or into fertile fields. Planting is one of the best measures for erosion control. The fertility of the soil is also increased by the forest. Trees convert the chemical elements from the soil, together with carbon from the air, into wood, leaves, and twigs. The wood may be removed from the forest, but the leaves and twigs are returned to the soil. This organic material forms the forest humus which is most important for the soil fertility. Even a poor sandy soil, if mixed with forest humus, may be very fertile. The humus may either be deposited upon the mineral soil (this humus type is called "duff"); or it may, by means of the soil fauna, such as earthworms, be incorporated into the mineral soil (this type is called "mull"). The mull is the most fertile forest soil and richer in plant food than most garden soil. Duff is especially found in northern climates at high elevations and under coniferous forests. Mull is typical of the best hardwood forests.

\section{FOREST TYPES AND THEIR CHARACTERISTICS*}

According to a report of the Society of American Foresters, a forest type is "a descriptive term used to group stands of similar character as regards composition and development due to given physical and biological factors, but which may be differentiated from other groups of stands ... a cover type is a forest type now occupying the ground, no implication being conveyed as to whether it is temporary or permanent." Thus there may be pure or mixed types, such as a pure redwood or pure ponderosa pine type, a mixed hardwood type, or a cypress and swamp hardwood type. There may be virgin timber types or types based upon location, such as alpine or swamp types, ridge types as the chestnut oak type, old field type as frequently found in New England, and cove type, as in the southern Appalachians. Types may also be based upon age and condition of the forests, such as a young, replanted white pine type or park-like type as found in the Rocky Mountains.

Hawley and his committee, in their study of types, have accepted the above definition, except that composition rather than development should be the primary basis of recognition. Cover types are based on the present tree cover; they are what the forester finds on

* For further treatment of this subject, see "Forest Cover Types of the Eastern United States," report of the Committee of the Society of American Foresters, R. C. Hawley; chairman, Washington, D. C., 1932. 
the ground and must deal with. This committee recognized 97 different types in the eastern part of the United States. Each type must occupy in the aggregate hundreds of thousands of acres and must be distinctive and easily separated from other cover types. Species form the basis of type names rather than location, age, site, or moisture.

Forest types may be constantly undergoing certain fundamental changes. Artificial exigencies, such as burning, logging, and land clearing for agriculture, interrupt the natural forces of nature. These

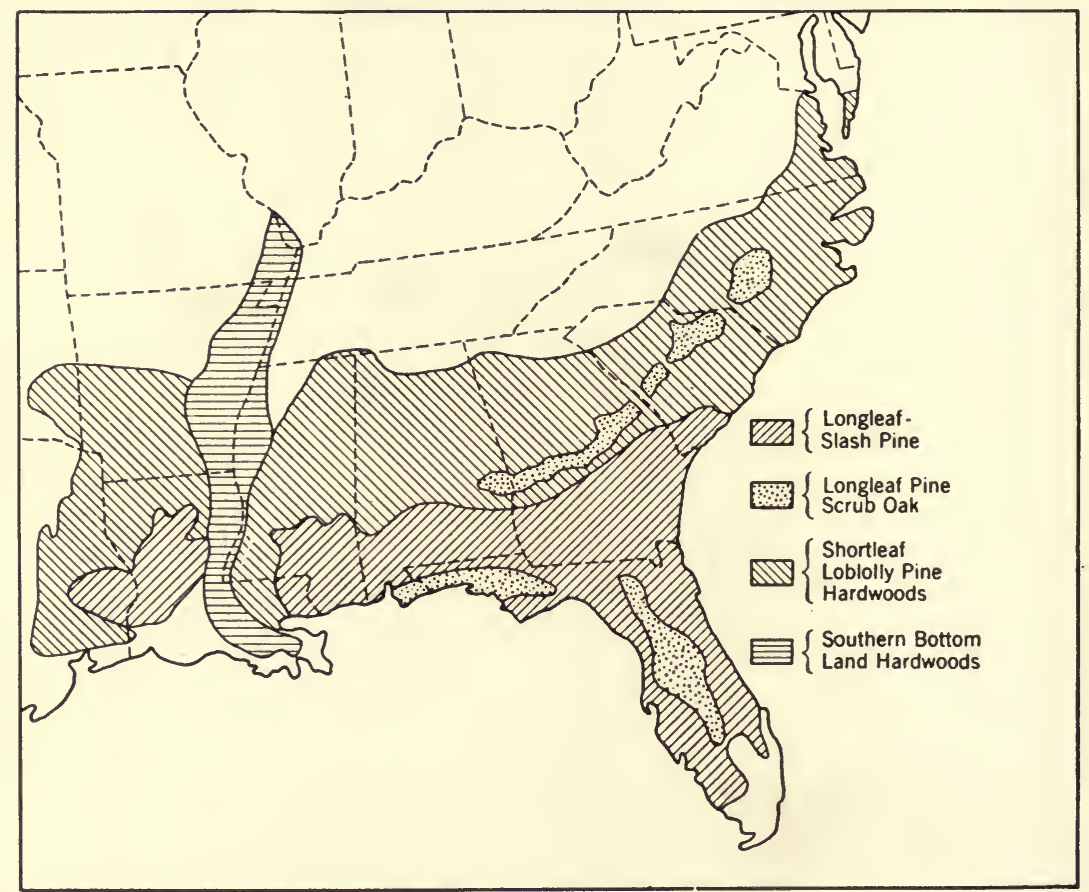

FIG. 32.-Distribution of forest types of the South. (After U. S. Forest Service.)

disturbances have a considerable effect upon the development and output of forest types. Climax types are those which are recognized by the forester as the type which is most suitable and natural for a given site. It is commonly believed that natural forces should prevail in the culture and development of forest types. For this reason, native rather than exotic species are generally favored in planting. The study of ecology of forest types has occupied the attention of many foresters. In the cutting of mixed hardwoods and softwoods of the Northeast, the native white pine and spruce have generally been the more valuable; therefore, they have been cut first. This un- 
natural intrusion by mankind has tended to cause the forest to grow up more densely with hardwoods such as the beech, birch, and maple, rather than to be regenerated with spruce and white pine. Natural and unnatural forces are constantly at work to develop or to disturb the formulation of forest types. A study and understanding of forest types and their development are most necessary in the application of silvicultural technique. The forester must understand the natural forces governing the development of forest types and must handle the forest so that the most efficient results may be obtained in the shortest length of time.

In the organization of any forest, one of the first duties is carefully to survey and map the tract and separate the forest into types. These types form the basis of the cutting cycles and rotations followed in the management of any tract. For example, most of our National and many of our State Forests as well as private tracts have been carefully surveyed to determine the location and condition of each type found within them. Information secured in these studies and surveys is used in making timber sales, logging plans, fire protection and road construction plans, and management plans for sustained yield.

\section{PURE AND MIXED FORESTS}

The relative advantages and disadvantages of growing trees in pure or mixed forests have been subjects for wide discussion among foresters. The problem applies both to naturally reproduced and to planted forests. Virgin forests are generally of mixed species. Pure forests are most frequently found in alpine regions. In artificially reproducing forests by planting, the general practice in the United States has been to use one species, thus forming pure forests.

According to Toumey and Korstian, ${ }^{*}$ advantages of pure stands are that the management is very simple, thinning requires little technical skill, natural pruning is much more uniform than in mixed forests, and the crop can be harvested more economically because only those species are grown which enjoy highest market prices. The planting of pure stands is much simpler, easier, and less expensive, and the resultant stand is generally more dense and the yield is accordingly higher.

The advantages of mixed stands or, conversely, the disadvantages of pure stands are that the pure stands do not generally improve the fertility of the soil, the danger from injury such as from fire, wind,

*See "Seeding and Planting in the Practice of Forestry," second edition, John Wiley \& Sons, 1931. 
insects, and fungi is greatly increased by using a single species, and pure crops may not occupy the ground or the site so completely, especially with intolerant species.

\section{FACTORS DETERMINING THE SELECTION OF SPECIES}

Among the more important factors which must be considered in selecting species to be grown in any part of the country, the following may be mentioned.

1. Rapidity of growth. It is important that trees mature or reach a merchantable size as early as possible because financial investments may accumulate more rapidly than the wood accumulates in volume and value.

2. Freedom from fire, insects, fungi, and other damage. Occasionally one or more of these factors may prevent the use of certain species in some regions. White pine is susceptible to the blister rust and weevil attacks, and therefore, under some conditions, it is not advisable to plant it.

3. Adaptability. The tree must be adaptable to the site, including the type of soil, character and amount of precipitation, slope, and aspect.

4. Marketability of forest products. This is of paramount importance. Unless trees can be profitably marketed, the financial phases of forestry may be seriously jeopardized.

5. As the objectives of forest management may be the cultivation and improvement of wild life, grazing, recreation facilities, or aesthetic effects, trees should be selected, planted, or left in cultural operations, that will lend themselves best to the objectives sought. For example, food-bearing plants should be encouraged when the primary objective is deer raising. When shelterbelts, windbreaks, erosion control, or other specialized objectives are sought, the trees must lend themselves best to achieve these results. For example, conifers furnish better wind protection for shelter projects throughout the year than do hardwoods.

6. The species that will best preserve and maintain the soil conditions. Under certain circumstances, the maintenance of proper soil fertility may be of paramount importance.

7. Location. Native species are generally preferred to exotics. If, however, exotics offer decided advantages, they should be used on the best locations and usually on small areas. 


\section{CHAPTER VI \\ FOREST PROTECTION}

\section{GENERAL}

Trees, by the very nature of their growth, condition, and location, are susceptible to many injurious agencies. Some trees have thick, coarse bark, like the redwood, that is resistant to fire; others have

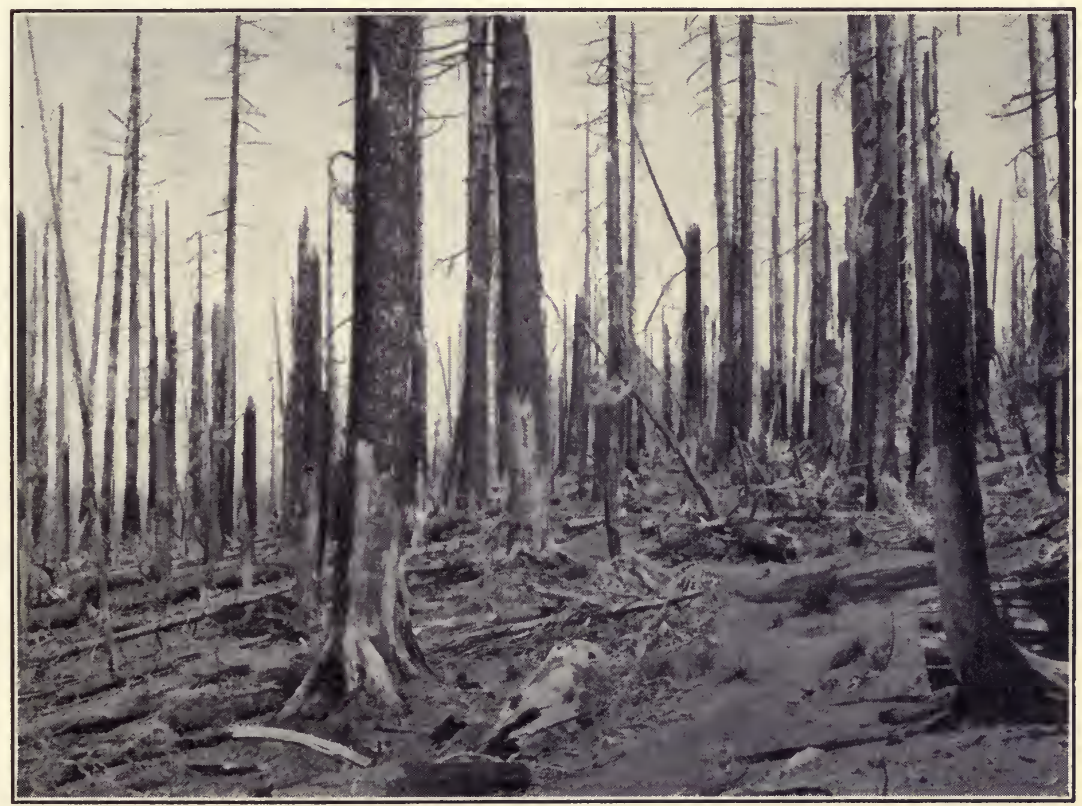

Fig. 33.-Burned timber on the Clearwater National Forest, Idaho. Millions of dollars in wages, valuable hunting and other values are lost in the annual toll of forest fires. Much progress is being made in better fire protection. Experience gained during the past years has been valuable in developing fire prevention and suppression technique.

thin bark, like the birches, which are readily scorched, injured, or killed by fire; some are more readily affected by insects and fungi than others. The protection of trees and forests against injuries is 
fundamentally important in the practice of forestry whether the object of management is timber production, watershed protection, range management, wild life and recreational development, or the preservation of scenic and aesthetic values. The history of American forests is replete with disastrous forest fires that were left to burn unchecked. Fires have destroyed more forests than the lumberman's axe. They are the greatest menace to the practice of forestry. It was largely because of the forest fire problem that interest in better care and management of our forests was awakened.

The subject of forest protection includes the problems of:

1. Forest fires.

2. Forest- and wood-destroying insects.

3. Forest- and wood-destroying fungi.

4. Grazing by domestic animals and other animal injuries.

5. Erosion.

6. Sand dunes.

7. Miscellaneous, including such natural phenomena as lightning, wind, frost, avalanches and landslides, and theft.

\section{FOREST FIRES-IMPORTANCE AND EXTENT}

American forests in every section have suffered from frequent and recurring fires. Some regions, as northern Idaho and southern California, are particularly susceptible to damage because of the inflammable nature of the forest and the forest floor, and the long warm periods without rainfall. Slash, débris, and brush left after logging operations have added measurably to the hazards in nearly every region and have been the cause of much state legislation to reduce the risk of fire.

Repeated fires have:

1. Destroyed much merchantable and growing stands of timber.

2. Destroyed young growth which must be relied upon to furnish the forests of the future.

3. Destroyed the humus and affected the forest floor conditions so that reproduction is difficult or impossible.

4. Depleted the vigor of growth so that timber values become definitely lowered.

5. Increased the activity of tree-killing insects and wood-destroying fungi following the ravages of forest fires.

6. Destroyed many lives and millions of dollars' worth of property, such as cabins, communities, and railroads, as well as 
valuable timber. Burned timber means the loss of direct and indirect wages, taxes, and other public benefits.

7. Destroyed much game, many camping grounds, and other recreational facilities.

The resultant effects of forest fires have been enormous in some sections of the country. Frequently it is generations before the fertility of the soils may be revived. Floods often follow fires and do considerable damage, as in southern California and the Appalachian

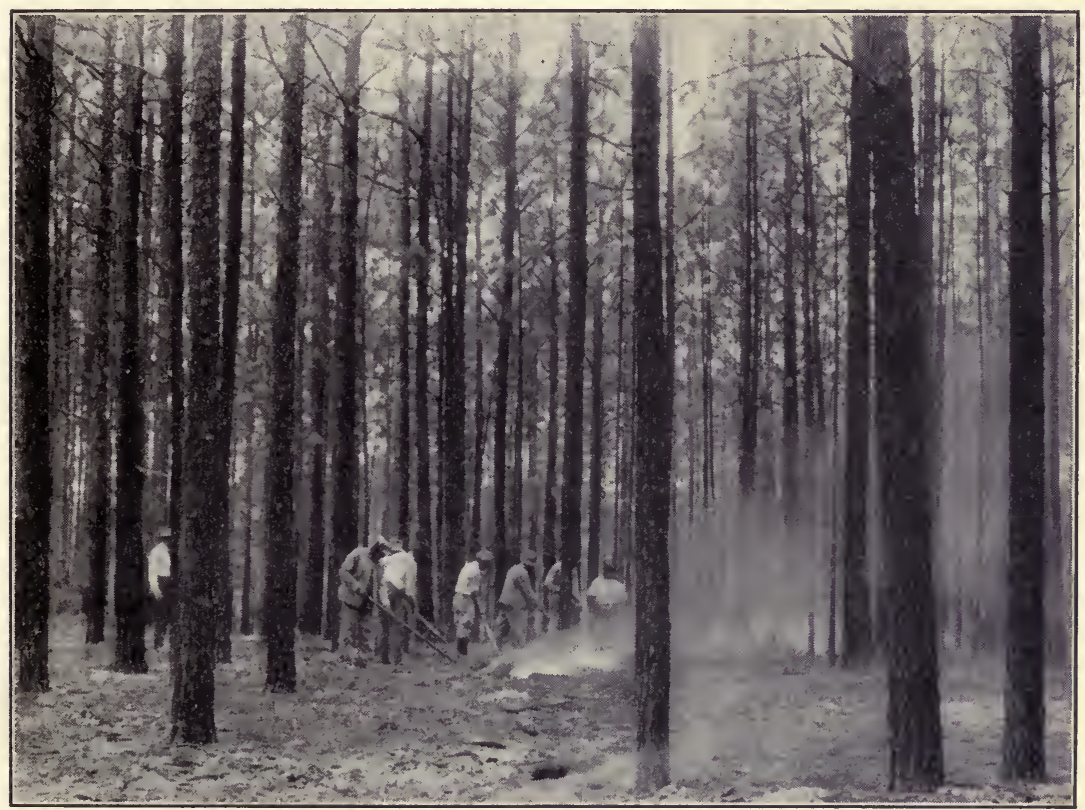

Fig. 34.-Fire crew at work combating a surface fire in longleaf pine stand, Georgia. Surface fires burn over millions of acres in the southern pine forests every year and do much damage to reproduction and standing timber.

Mountains. One of the major problems of American forestry is to rebuild depreciated forests that are in exceedingly poor growing condition as the result of repeated burnings.

Fires may be classified as follows:

1. Crown fires which burn in the crowns of coniferous growth and generally kill the trees outright. These are the most destructive and damaging forms of fires; they are generally found only in the coniferous stands of the Pacific Coast and the Rocky Mountains, but sometimes in the Lake States, the 
Northeast, and portions of the Appalachian Mountains. Crown fires are especially serious in young and growing plantations of coniferous trees as they may completely destroy them.

2. Surface fires which often kill seedlings and young trees, deplete the fertility of the soil, injure standing timber, lower the rate of growth, and invite the presence of insects and fungi. These are particularly prominent throughout the southern pine forests and also occur in nearly every section of the country. Surface fires may quickly become crown fires under conditions conducive to their spread.

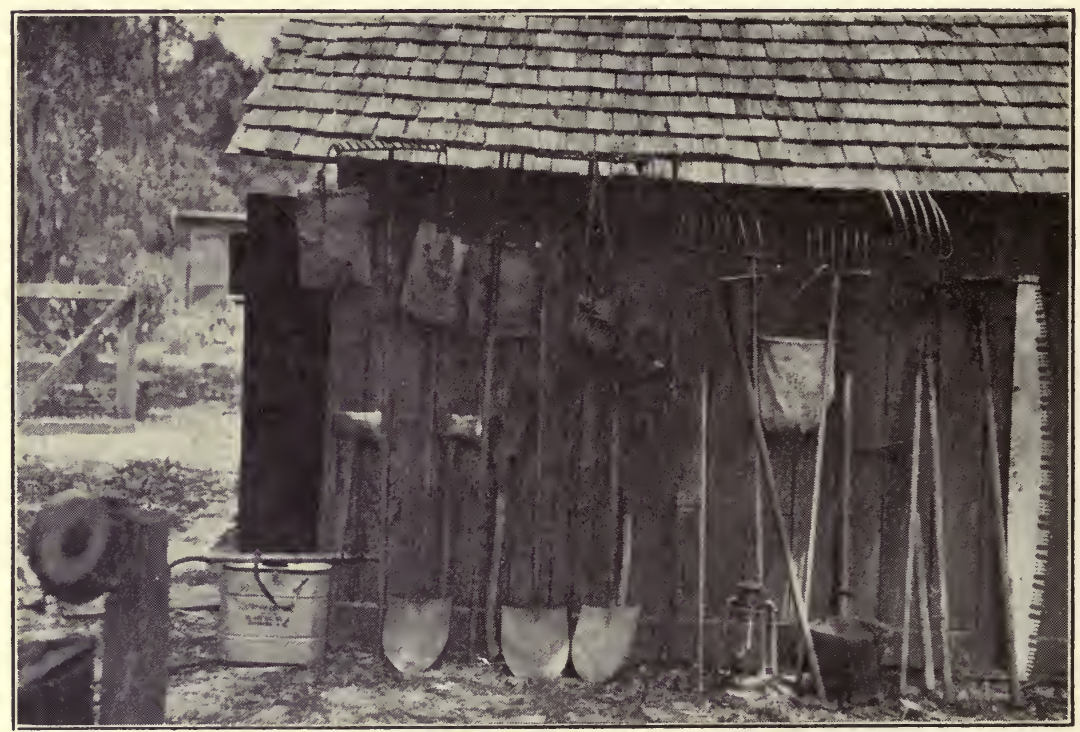

Fig. 35. - 10-man fire fighting equipment. Ocala National Forest, Florida. Rakes, forks, shovels, wide faced hoes, axes and cross-cut saws are the tools most commonly used in the southern pine forests.

3. Ground fires which occur principally in peat, duff, humus, and moss, especially in swamps such as the sphagnum swamps in the Lake States and the Northeast. When swamps dry out, ground fires occur occasionally in the South and Southeast. They generally burn slowly, but often very disastrously.

Organized forest fire control began about 1905 with progressive state legislation, and systematic fire prevention and control in the National Forests through the erection of lookout stations, towers, and cabins together with telephone lines. The technique of fire protection 
has been widely studied by federal and state authorities during recent years. An excellent plan of fire protection covering other federal properties as well as State Forests and private holdings, generally in cooperation with state and federal authorities, has been very effective, notably in the Pacific Northwest, the northern Rocky Mountains, California, and Maine. Several protective associations have made notable contributions in saving our forests from fire.

Fires are being partly controlled in federal and State Forests and in private forests. Fires have burned over about 41,000,000 acres annually, or more than the area of the states of Michigan or Georgia.

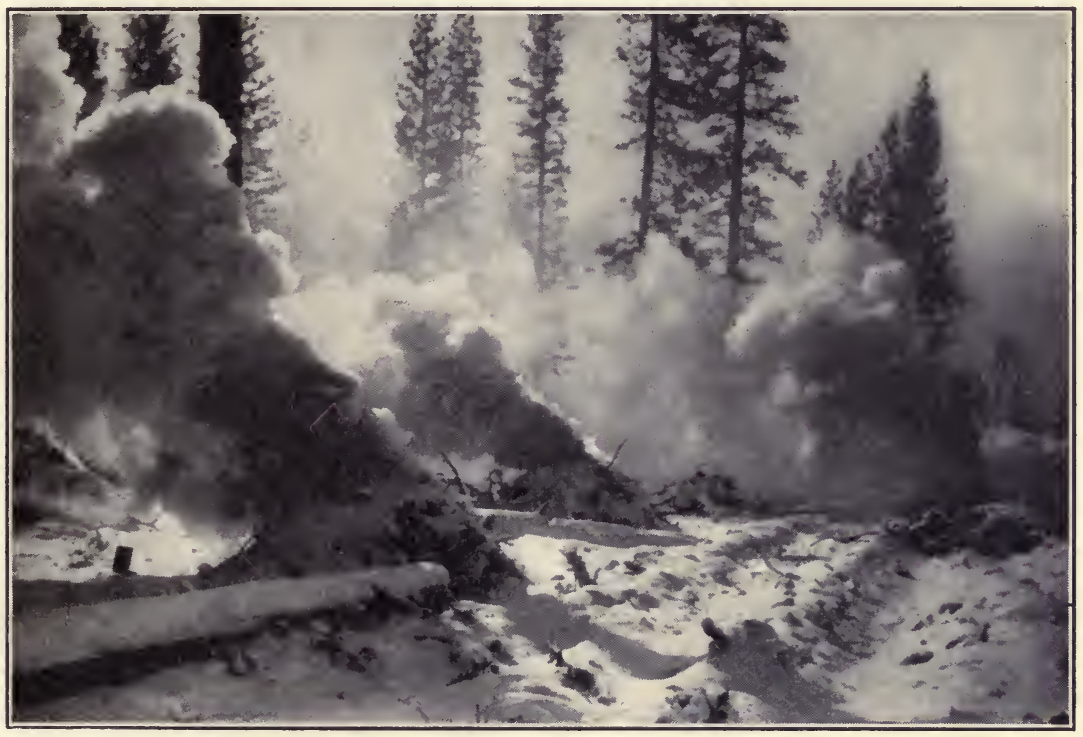

Fra. 36.-Brush burning on Stanislaus National Forest, California, during winter to reduce the fire hazard on logging operations. Slash left after logging constitutes a serious fire menace in dense coniferous timber.

About $63 \%$ of the total present and potential forest areas of the nation now réceives some form of protection. This represents definite progress over the previous neglect and indifference. Although $100 \%$ protection is doubtful of accomplishment, more effective protection should be given our forests and especially our farmer's woodlots and small private holdings.

Over $\$ 5,400,000$ are annually expended for fire protection on state and private lands, or a cost of 1.29 cents per acre. The expenditure on National Forests is over $\$ 5,000,000$, an average annual cost of 5.72 cents per acre. 
Fires in National Forests during a recent five-year period show that the annual average area burned over is relatively small compared with previous years. Fires which burned over one-fourth acre or less comprised $56.31 \%$ of all fires, those between one-fourth acre and 10 acres formed $26.92 \%$ and those of 10 acres or more composed the balance of $16.77 \%$. Thus the great majority of fires are detected quickly and suppressed promptly. Quick attention and access to incipient fires and their prompt control are of outstanding importance in the entire fire problem.

Some examples of great forest fire conflagrations are as follows:

1. The Miramichi fire of 1825 in New Brunswick spread to a vast acreage within 9 hours. It finally covered an area 80 miles long by 25 miles wide and burned over $2 \frac{1}{2}$ million acres. Several communities were burned, and 160 people perished in this terrific fire.

2. The great Peshtigo fire of 1871 in Wisconsin burned over an area of about 2000 square miles, and approximately 1500 people were killed as a result.

3. In the Hinckley fire in Minnesota in 1894, Hinckley and six other towns were laid waste. Many miles of railroad were destroyed, about 500 people perished, and the property loss exceeded $\$ 25,000,000$.

4. The northern Idaho conflagration of 1910 burned large areas of valuable western white pine timber, principally in the National Forests. Over $\$ 25,000,000$ worth of valuable timber was lost within a period of two weeks. Many millions of dollars worth of property were destroyed, several towns completely burned up, and many lives lost.

5. The great Tillamook fire in northwest Oregon in 1933 burned principally on private holdings and covered more than 300,000 acres. It burned for 11 days, killing approximately 11 billion board feet of excellent timber and resulting in a loss estimated at more than $\$ 200,000,000$. It is reported that a yearly tax of $\$ 400,000$ or $43 \%$ of all taxes levied in one county was lost and that six years of wages for 14,000 workers, or over $\$ 100,000,000$ annually were taken away from these communities in prospective employment. Thus one appreciates the intimate relationship between forest fires and employment in logging, sawmilling, transportation, and distribution of forest products.

In California light burning, that is, annual or periodic burning of 
the woods to reduce the inflammable material and thus to avoid serious conflagrations at infrequent intervals, is practiced by some of the lumbermen. Generally speaking, this practice has been abandoned as it was found that too much damage was done to the standing timber.

\section{CAUSES OF FOREST FIRES}

The increasing use of forests by the public has brought greater hazards and an increasing number of fires. Human carelessness is responsible for a very large share of the fires. Altogether, the number of fires has increased rather than decreased in the last 25 years, although the resultant losses and areas burned have generally diminished. Public education and response to the seriousness of the forest fire problem are more necessary than ever. The increasing use and occupancy of forested areas involve the constant need of fire for cooking and warmth as well as for de-

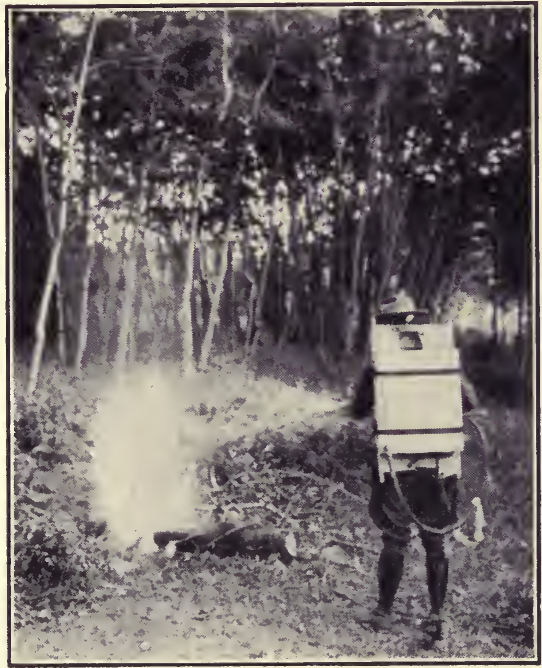

Fig. 37.-Water pump used in direct attack on fire. Many improvements have recently been made in portable pumps and hose. A small water supply may be carried if water is not available in a nearby stream or well dug for the purpose. Wells have been used successfully in the Lake States. stroying accumulated débris and for proper land clearing and logging. Through human carelessness or intent, many fires are started. Lightning is the only natural cause.

The causes of fire during a five-year average in our National Forests is shown as follows:

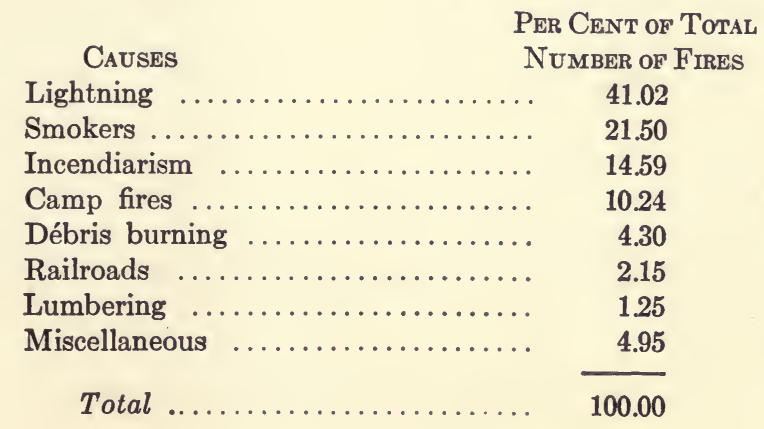


On private and State Forests, causes vary widely in different parts of the country. The situation in the National Forests presents a good representative summary of the general causes of forest fires. In the South, where fires are most frequent and prevalent and burn over the largest area, fires are intentionally set to improve the grazing and reduce the number of cattle ticks. Crown fires seldom occur in southern pine forests, except in young, dense stands. The question of the annual burning of the woods in the South has been a debatable one for many years. Chapman has shown that, under certain conditions, fires may improve longleaf pine reproduction. Incendiaries have caused $71 \%$ of the forest fires in Florida and a very large share in most of the southern pine states.

\section{METHODS OF DETECTION}

Speed in detecting and reporting fires is of the utmost importance. Generally forest fires are detected by:

1. Lookout men stationed at high elevations on towers, cabins, platforms, or rocky points connected with the nearest permanent community or ranger station by telephone. A definite system of primary and secondary lookout stations has provided excellent protection in our National Forests, National Parks, and many of the State Forests. Great advances have been made in the development of the Osborne forest fire finder, telescopes and maps, etc., to aid in the location of fires as they are observed.

2. Patrol by guards, wardens, and other forest workers along forest roads and trails and on logging operations in regions of serious fire hazard.

3. Public volunteer reporter system, as railroad train men, motorists, hunters, fishermen, and vacationists, who have frequently been of great assistance in reporting fires to responsible authorities.

4. Airplanes have been occasionally used in eastern Canada and in many sections of the West.

Communication systems, chiefly the telephone, are of great importance, and many thousands of miles of telephone lines have been constructed. The heliograph and telegraph have also been used. Patrol is conducted by auto, on horseback, or on foot. Owing to improved highway systems, the automobile is most frequently used, not only for patrol but also for bringing men quickly to the scene of 
action. The presence of large numbers of men of the Civilian Conservation Corps has materially aided in both the detection and suppression of many forest fires throughout our forest regions.

During times of frequent forest fires, when the atmosphere is cloudy or hazy and observation difficult, smoke chasers and special men are employed to discover the new fires and report upon their location.

\section{METHODS OF PREVENTION}

Many methods are pursued to prevent fires. As mankind is chiefly responsible for the presence of so many fires, a great many laws and educational measures have been adopted to reduce the appalling number.

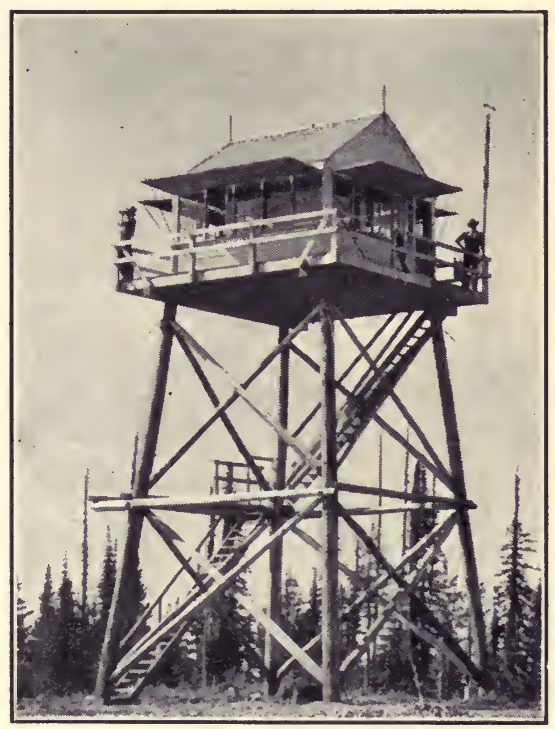

FIG. 38.-Jackknife lookout tower, Coeur d'Alene National Forest, Idaho.

Among these legal and educational measures designed to prevent fires on the part of campers, tourists, loggers, vacationists, hunters,

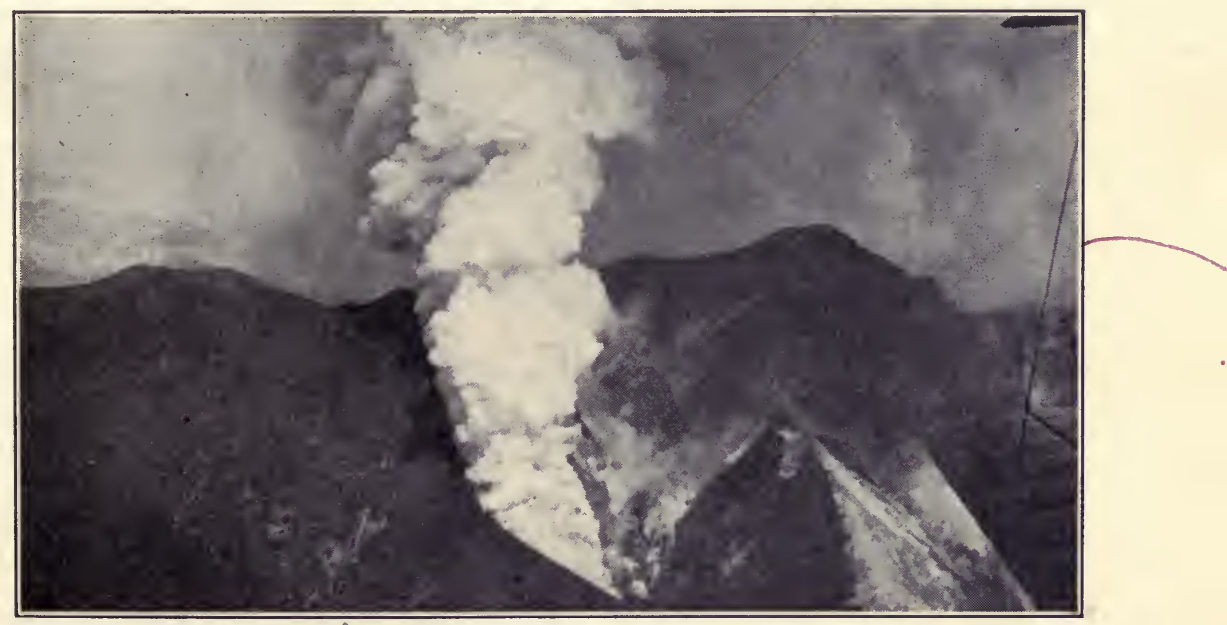

FIg. 39.-Airplane view of forest fire, Santa Barbara National Forest, California. Fires have done enormous damage to these forests which are chiefly valuable for watershed protection. 
and the general public visiting the forests are the following. They may appear to be rather severe in some localities, but experience has indicated that most of them are very necessary.

1. Permits are required for camp fires. In some regions a permit is required for everyone building a camp fire during certain dangerous seasons.

2. Registration with a fire warden or guard when entering a forest area, especially in regions of serious fire hazards as in southern California on Sundays and holidays.

3. Restriction of camping and camp fires to designated areas where inflammable débris, such as brush, needles, and leaves, have been removed, fire lines constructed, and fire places provided for each group. Open fires are generally prohibited.

4. No smoking is permitted along highways or anywhere in areas of extreme danger except in designated locations, known as "fag stations." Great advance has been made in this respect in the Pacific Coast States. Frequently motorists are not permitted to smoke even in their own cars when passing through areas of serious fire hazard.

5. Frequent contact, inspection, and observation by patrolmen, guards, and rangers. Local, county, and state patrol is vigilantly necessary to enforce the observance of laws and regulations in many sections.

6. Special fire-fighting tools such as shovel, axe, and water bucket must be carried by every motorist entering some areas. These are useful tools for camping as well as fire fighting.

7. Educational measures such as roadside signs, windshield stickers, evening lectures, and daily demonstrations at recreational and community centers, together with the usual newspaper, radio, and similar publicity efforts. Railroads, hotels, and oil companies frequently warn the public about fires in their folders, maps, and other literature.

8. Some forests or certain areas are sometimes closed to all hunters and visitors during periods of extreme or prolonged drought. This emergency measure has been resorted to in several parts of our National Forests and Parks, as well as in the Adirondack State Park in New York and in other sections.

Among other measures and regulations designed to prevent the occurrence of forest fires are:

1. The stopping of al' logging operations in the Pacific Coast States 
and the northern Rockies when the humidity falls below certain levels.

2. Weather prediction by the Weather Bureau, Forest Service, and other officials. Recent studies have pointed the way to making accurate predictions regarding weather to assist in preventing fires.

3. The equipment of railroads with spark arresters, tanks on flat cars, pumps, and hose readily available for action in case

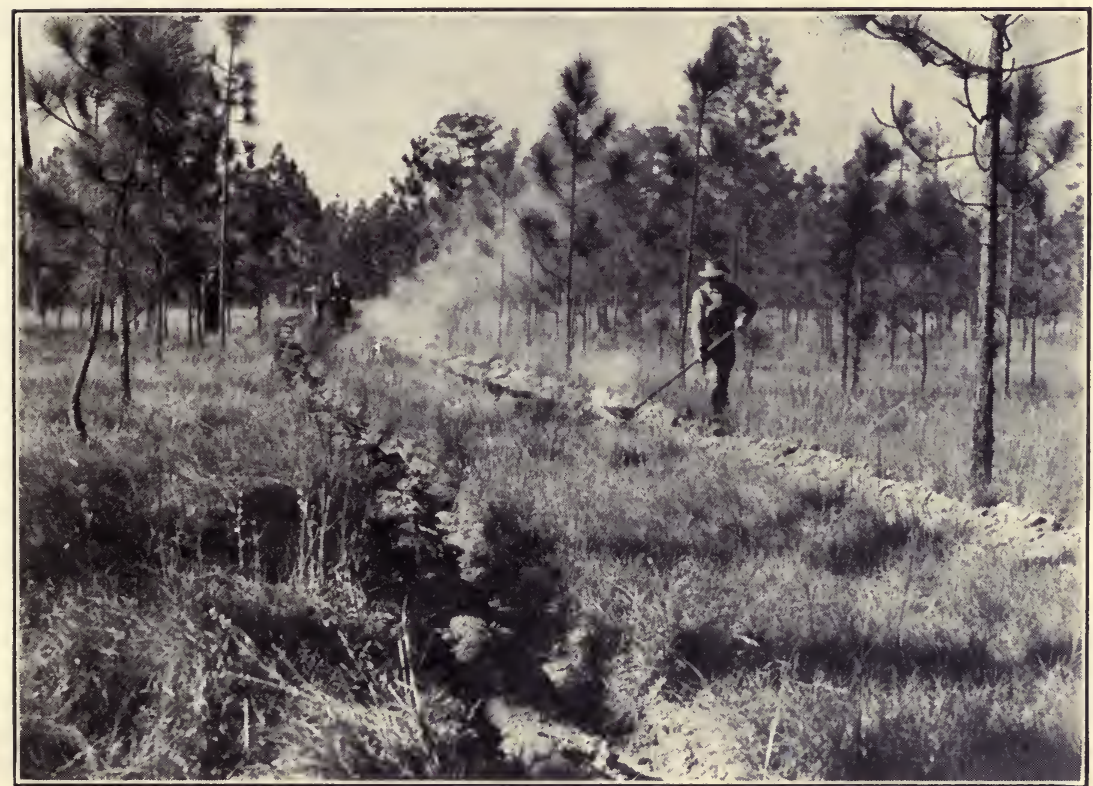

FIG. 40.-Burning fire lane between plowed furrows in second-growth longleaf pine stand. Stapleton, Baldwin County, Alabama. The elimination of inflammable grass, etc., in the lane prevents the spread of surface fires across it. Burning of the lanes should be done when there is no wind and preferably in the late afternoon or evening.

fires are reported. The change from wood and coal to oil as fuel has materially aided in lessening the danger of fires on logging and sawmill operations.

Five rules are commonly established for preventing fires. They are generally displayed on roadsides, at hotels, gasoline stations, or in literature. In many forested sections much progress has been made in educating the public to observe these rules.

1. Matches-be sure they are out. Break in two parts before throwing away. 
2. Tobacco-be sure cigars, cigarettes, or pipe ashes are "dead" before throwing away. Stamp them out-never throw into leaves, needles, or brush.

3. Make camp fire in holes in mineral soil. Scrape away all leaves, duff, etc., for 6 feet in all directions. Never build fires against a log, and keep them small.

4. Put fire out with water or earth when leaving camp either temporarily, for the night, or when breaking camp.

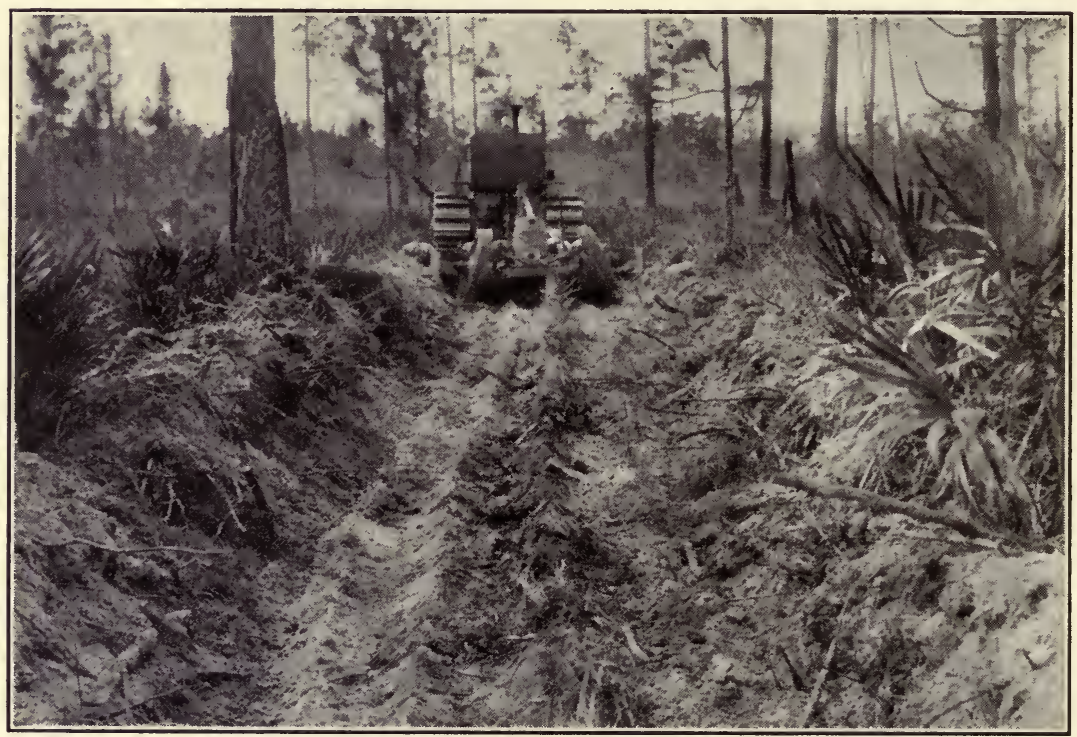

Fig. 41.-Constructing fire blocks or lanes on the Superior Pine Products Company property near Fargo, Georgia. About 1200 miles of fire lines have been plowed in this way on a 200,000 acre forest. A special type of plow is hauled by a Caterpillar Diesel 50 h.p. tractor.

5. Never burn brush or slash in windy or dry weather. In many states a permit is required to burn brush during certain months.

In order adequately to prevent fires and arrange for their suppression and control there must be an organization to provide for certain activities and facilities. Among these may be mentioned the following:

1. Means of detection, such as lookout towers, etc.

2. Means of communication for reporting fires and securing assistance. 
3. Means of transporting men and equipment.

4. Construction of fire lines or firebreaks. More has been accomplished in southern California in this respect than in any other section.

5. Roadside clearance, brush burning, and reduction or elimination of inflammable materials.

6. Fire-weather prediction.

7. Precautionary measures on railroads, logging operations, sawmills, etc.

8. Caches of tools such as shovels, axes, and cross-cut saws; equipment such as pumps, hose, and trucks; and food supplies at strategically located points.

The following table gives a partial summary of the tools and equipment required by the forest practice rules of the West Coast Lumbermen's Association.

\begin{tabular}{|c|c|c|c|c|}
\hline $\begin{array}{l}\text { ToOLS AND } \\
\text { EQUIPMENT }\end{array}$ & $\begin{array}{l}\text { EACH } \\
\text { Loco- } \\
\text { Motive }\end{array}$ & $\begin{array}{c}\text { SPEEder } \\
\text { Patrol- } \\
\text { MAN }\end{array}$ & $\begin{array}{l}\text { Motor } \\
\text { LogaING } \\
\text { TrUCK }\end{array}$ & $\begin{array}{c}\text { EACH } \\
\text { LoGGING } \\
\text { Side }\end{array}$ \\
\hline Spark arrester $\ldots \ldots \ldots \ldots \ldots$ & 1 & - & 1 & - \\
\hline Axes...$\ldots \ldots \ldots \ldots \ldots \ldots \ldots \ldots$ & 1 & 1 & 1 & 3 \\
\hline Shovels $\ldots \ldots \ldots \ldots \ldots \ldots \ldots$ & 3 & 2 & 1 & 6 \\
\hline Hand water pumps $\ldots . \ldots \ldots \ldots$ & 1 & 1 & - & 1 \\
\hline 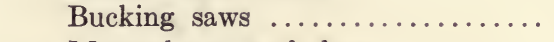 & - & - & - & 2 \\
\hline Mattocks or grub hoes .......... & 1 & - & - & 6 \\
\hline 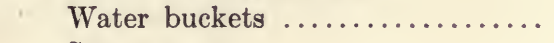 & 2 & - & - & - \\
\hline 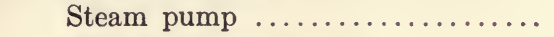 & 1 & - & - & - \\
\hline Portable power pump .......... & - & - & - & 1 \\
\hline Hose (No. feet) ............... & 300 & - & - & - \\
\hline Chemical fire extinguisher $\ldots . \ldots$. & - & - & 1 & - \\
\hline
\end{tabular}

States which require general slash disposal after logging operations are Washington, Oregon, California, Idaho, and Montana in the West; Minnesota in the Lake States; and the Adirondack Mountain portion of New York. States requiring limited slash disposal along roads, railroads, and property lines, are the New England States except Vermont and Rhode Island; the balance of New York; Wisconsin and Michigan in the Lake States; Ohio, Pennsylvania, New Jersey, and Maryland in the East; and New Mexico in the Southwest.

States requiring private owners to provide fire protection or to support protective organizations are California (except in redwoods), 
Oregon, Washington, Idaho, Montana, Kentucky, West Virginia, New Hampshire, and certain fire districts in northern Maine.

\section{METHODS OF CONTROL AND SUPPRESSION}

Speed of attack is the great essential in successful fire control in the forest as well as the city. If fires are discovered and reported promptly, and men and equipment are available and accessible, a

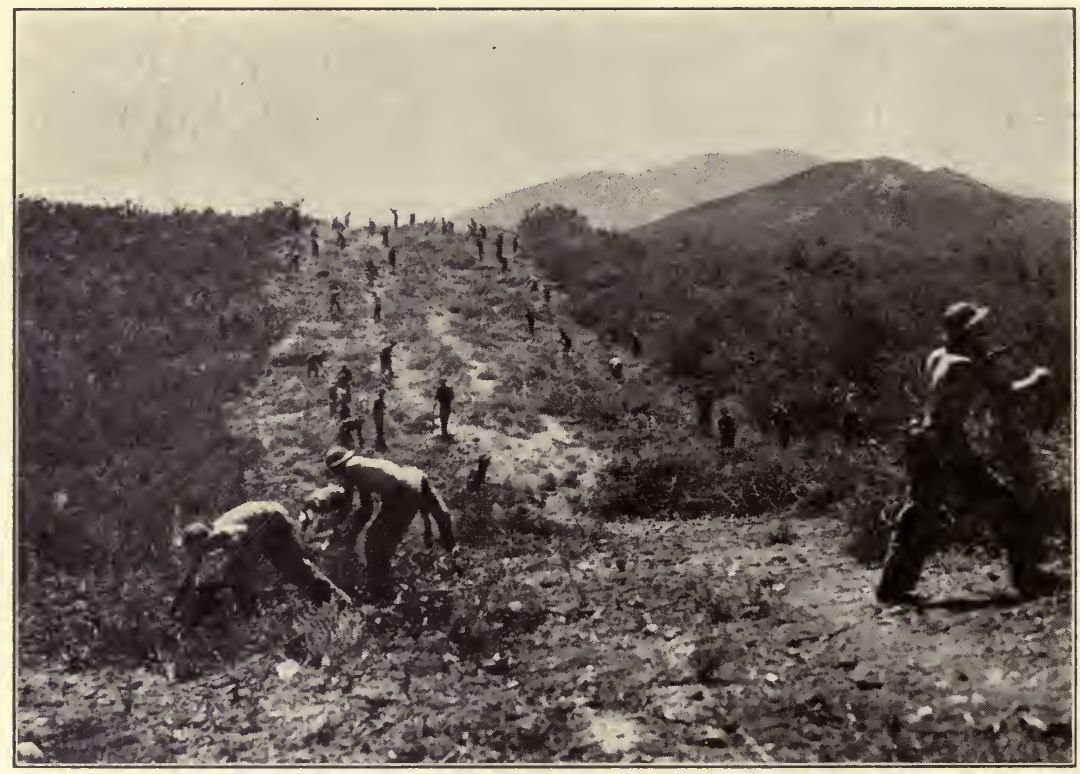

FIG. 42.-Constructing a fire break on the "Elfin" forests, composed largely of chaparral, manzanita, etc., in southern California. The fire menace is very serious in this region. The elimination of all inflammable material on this strip assists in stopping fires along the ridges. They may also be used as vantage points for back-firing.

minimum of loss may be suffered. It has been said that almost every fire can be stopped by the stamping of the foot.

Much progress has been made in advancing the technique of fire control, notably in the three Pacific Coast States and the northern Rocky Mountains, where the forest fire hazard is most severe.

The methods of control may be summarized as follows:

1. Direct attack with tools. The shovel is the most effective firefighting tool. Earth is applied directly to the advancing flames of surface fires. Inflammable material, such as fallen logs, snags (dead standing trees) brush, and leaves, are cut 
away with the axe, the saw, and rakes so that a direct attack may be made.

2. Direct attack with water. Recently improved portable pumps have been designed and manufactured with sufficient hose to carry water long distances. Ordinarily, fires do not burn where water is readily available. In Michigan, water holes have been dug for a water supply in connection with pumps. Under certain conditions they may be the most effective instruments in stopping fires.

3. Digging trenches to mineral soil in advance of the fire. Some of these trenches may be from one to 20 miles in length. Secondary and tertiary trenches are sometimes constructed to add to the line of defense. The inflammable material, such as leaves, brush, and windfalls, are cleared away on both sides of the trench. This is the most useful and effective method of combating ground fires.

4. Use of wet blankets, wet

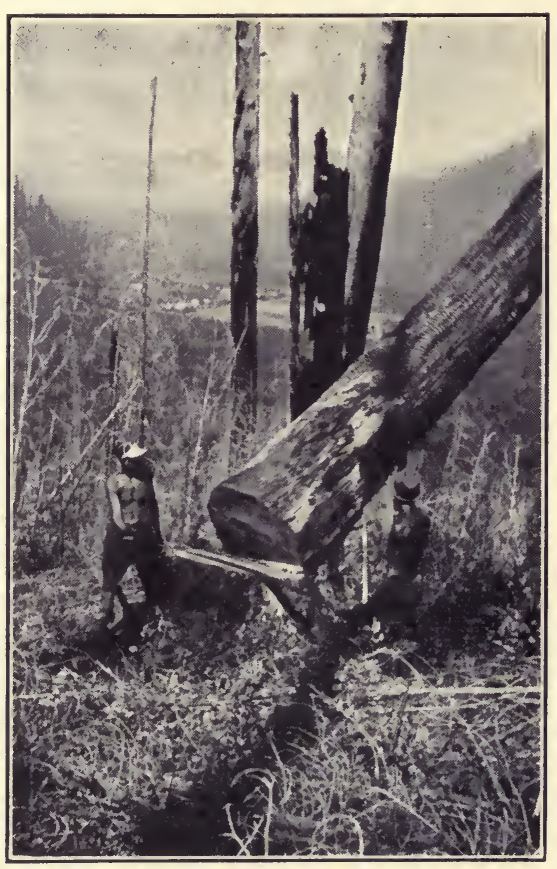

FIG. 43.-Felling a large snag or firekilled tree on a firebreak in Washington. These snags, when afire, may send flaming brands in the wind to distant green timber and start new fires. Snag felling is an important part of fire protective work in the Northwest. burlap bags, and other materials to put out fires. This may be the quickest way to smother and stop many surface and grass fires.

5. Back fire. In crown fires or severe surface fires, back firing may be effective. It is exceedingly dangerous, however, particularly in windy weather.

6. Fire lines and firebreaks constructed along the tops of ridges have proved to be very effective. They must be maintained and kept clear of any inflammable material. 
The best time to fight fire is at night or as soon as the dew falls and humidity in the atmosphere rises. Between midnight and sunrise is generally the most effective time, especially in dense, heavy coniferous timber of the Northwest, Northeast, and Lake States.

\section{SOUTHERN FOREST FIRE PROBLEM *}

The southern pine forests present an outstanding feature of the fire problem. For many generations it has been the custom purposely to burn over the woods in the South every winter. This was done to remove the litter, dead grass, and herbaceous vegetation during late winter and early spring, so that new grass would be more readily available as forage for cattle. Dense reproduction and brush lessen the value of the land for grazing, and burning was considered helpful in retarding or eliminating this undergrowth. Some areas were purposely burned to protect fences, farm buildings, and turpentine orchards from accidental fires.

For a recent five-year period figures issued by Demmon indicate that $75 \%$ of the fires reported in the United States occurred in the eleven southern states and that more than $90 \%$ of the total area estimated to have been burned over was included in these states. The frequency of fires in the South since the days of first settlement has been due partly to the high inflammability of the surface vegetation during the winter months. Surface fires, however, may burn during any month of the year. In very dry periods, surface fires spread with great rapidity, and occasionally crown fires develop. The usual surface fires seldom exceed a height of 3 to 5 feet.

Recently, after extended experiments and many studies, the attitude of several foresters has changed with respect to attempts to exclude all fires in the South. Demmon states that controlled burning may be used for specific silvicultural and forest management purposes by preparing the seedbed so as to secure initial stocking of longleaf pine seedlings. Fires may assist longleaf pine seedlings by controlling the brown-spot needle disease, by discouraging competing vegetation, and by reducing excess fire hazards and occasionally serious loss by accidental fires. Incidentally fires may improve the longleaf pine pasture and conditions for game. The use of fire in the management of southern pine forests requires great judgment and skill and a knowledge of when and how to burn for specific purposes.

* For a recent discussion of the southern forest fire problem see articles by Demmon, Hardtner, Wahlenberger, Greene, Eldredge, and Stoddard in the Journal of Forestry, Washington, D. C., March, 1935. 
Hardtner of Louisiana has pointed out that, by burning areas of great hazard during late afternoons on cold damp days in winter, serious fire hazards may be reduced or eliminated. He now has in Urania forest a fully stocked stand of 70,000 acres reproduced on logged areas, which cannot be replaced for $\$ 20$ per acre. He states that the general public has a $90 \%$ interest in these values-a stake worth making a great effort to save.

\section{FOREST INSECTS}

Insects have done an enormous amount of damage to standing timber, manufactured lumber, and various forest products. Insects operate in a most insidious and oftentimes invisible manner. Hopkins estimated that the annual loss from forest insect depredations amounted to more than one hundred million dollars, or a reduction of $10 \%$ in the value of the annual output of forest products. Insects operate chiefly in mature and over-mature timber, forests injured or killed by fire, and in many forms of forest products.

The injury may result in deforming, weakening, or destroying single trees or in the killing of a large portion of standing timber covering thousands of acres in extent. Insects may become epidemic at irregular intervals and then practically disappear.

Furst has classified insects as follows: boring insects, which affect the bark, sapwood, and heartwood; defoliating insects, which destroy the leaves of trees; root-destroying insects; bud destroying insects; seed-destroying insects; and those which cause deformation or malformation. There are also insects, known as powder post beetles and termites, which destroy or injure manufactured forest products. Some of the species that have caused most serious damage are as follows:

1. Gypsy moth and browntail moth introduced from Europe have caused enormous damage in New England by eating the leaves of both fruit and forest trees. Extensive funds have been appropriated to suppress or check the spread of these insects by spraying-dustingcreosoting and by parasite introduction.

2. Southern pine beetle. This has done a vast amount of damage in the South and Southeast, killing millions of feet of southern pine.

3. Spruce budworm. This has been prevalent in the Northeast, especially in Maine, destroying many thousands of acres of valuable spruce balsam timber.

4. Termites work up from the ground into wooden foundations and do an enormous amount of damage in California and in the southern portions of the country east of the Mississippi River. 
5. The white pine weevil kills the leader or tip of the common pines of the East except red pine. Norway spruce is also badly injured.

6. Western pine bark beetle destroys over two hundred million board feet of the best ponderosa pine annually.

7. The mountain pine beetle destroys enormous quantities of lodgepole pine in the Rocky Mountains each year.

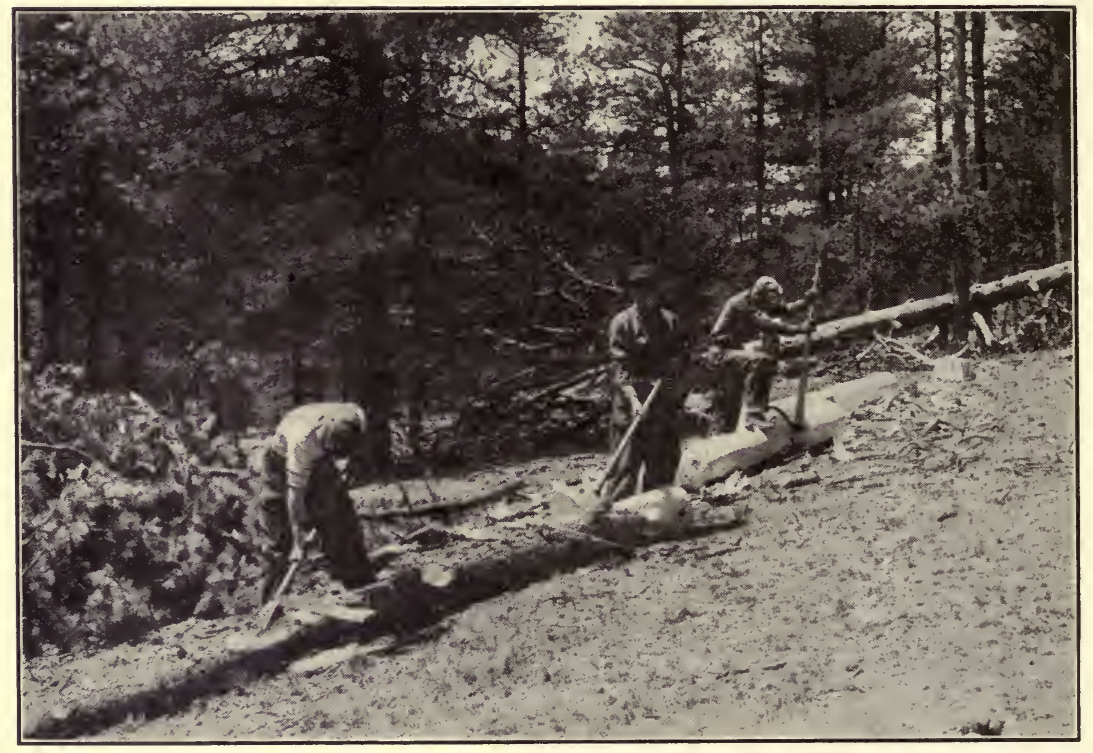

Fig. 44.-Peeling the bark from insect-infested ponderosa pine in a western National Forest. Two men on the left are using bark spuds, the man on the right has a peavy, which is used to roll the log down to a landing.

8. Other important examples of insect pests are the locust borer, which riddles the heart and sapwood of locust, with the result that this valuable tree is discredited for planting in some regions; the catalpa sphinx, larch sawfly; and the hickory bark beetle.

The marine borers, namely, teredo and limnoria, are mollusks and not insects; they have destroyed large quantities of piling, harbor improvements, bridges, and vessels and are a serious problem for the zoologist and timber preservation engineer.

The Division of Forest Insects in the Bureau of Entomology and Plant Quarantine in the U. S. Department of Agriculture devotes its activities to the investigation of forest insect problems and cooperates closely with the Forest Service, the National Park Service, Bureau of 
Indian Affairs, and private owners in preventing and suppressing insect attacks and epidemics. This Division, in addition to the main office in Washington, maintains branch offices or representatives at Berkeley, California; Coeur d'Alene, Idaho; Portland, Oregon; New Haven, Connecticut; Ann Arbor, Michigan; Madison, Wisconsin; Asheville, North Carolina; Columbus, Ohio; Denver, Colorado; and Melrose Highlands, Massachusetts. Several states employ forest entomologists or some specialist in charge of pest control (insects and fungi), as in New York and Connecticut.

Methods of control, as summarized by Hawley, are the protection and increase of the natural enemies of the insects such as birds and other insects; the removal from the stand or treatment of infested trees; disposal of slash and other material in which the insects find favorable conditions for breeding; and special silvicultural measures to prevent the creation of conditions favorable to insect attack. The use of creosote and other toxic chemicals to protect piling and other structures from marine borers, as well as against termites, is strongly recommended, and these materials are widely used.

\section{FOREST FUNGI}

Fungi are living organisms belonging to the plant kingdom. Unlike the green plants, they are unable to make their own food and must secure it at the expense of the green plants. In so doing, they cause disease and deterioration of living plants and plant products. Fungi are responsible for enormous losses of both living and dead wood as well as of many forms of forest products. They attack and destroy forest trees of all ages, from seedling stage to maturity. All parts of a tree are subject to their attack. They cause leaf diseases, root rots, fruit injury, and deterioration of the trunk.

Since fungi are both parasitic and saprophytic in nature, they are able to attack dead and living trees and many manufactured forms of forest products. A few examples of the damage caused by fungi are as follows:

1. Lumber is frequently degraded and sold at much lower prices than clear stock because of sap stain. Sap stains frequently occur in freshly sawn timber of white and yellow pines, red gum, yellow poplar, and other species.

2. Chestnut bark disease was first discovered near New York City in 1904. It has practically destroyed all native stands of American chestnut. The fungus causes the death of the trees by destroying the cambium and inner bark. Efforts are being made to develop im- 
mune chestnut species by crossing American chestnut with Japanese varieties which are only slightly susceptible to the bark disease.

3. White pine blister rust has already caused considerable damage throughout the range of white pines in the East and Middle West, as well as in the Northwest and Inland Empire. Large sums of money have been appropriated by the Federal Government, by various states, and even by private groups and individuals to combat the spread of this disease. The fungus which causes white pine blister rust lives alternately on various species of native and cultivated Ribes (cur-

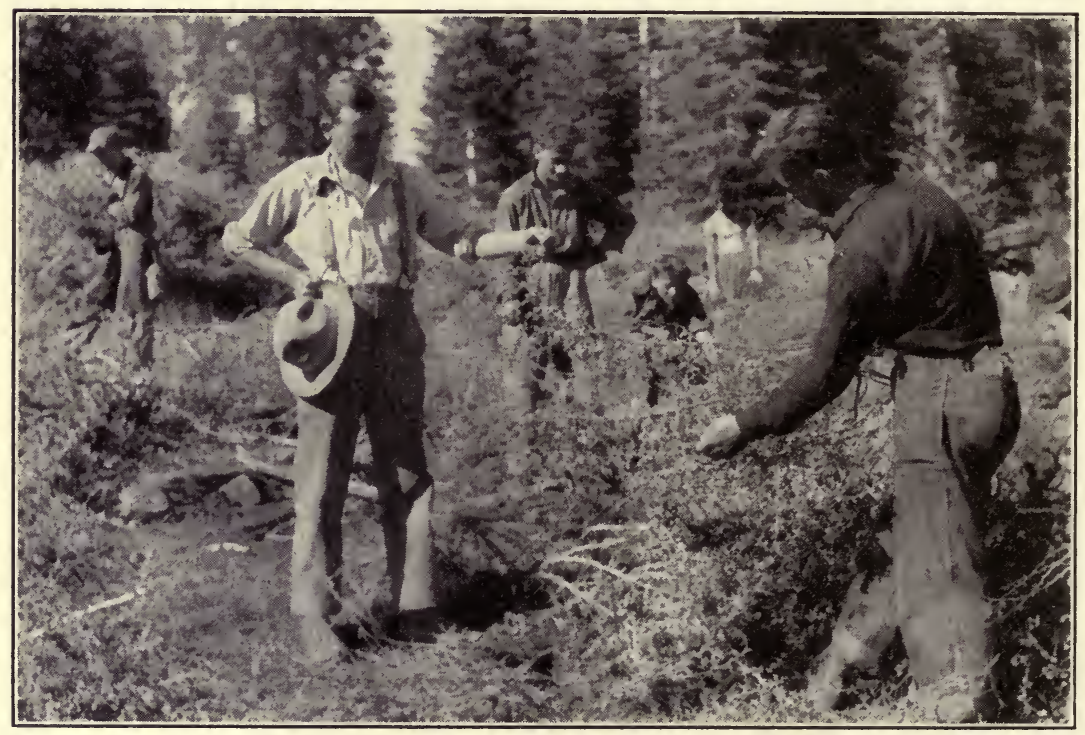

Fig. 45.-The eradication of currant and gooseberry bushes to prevent the growth and spread of white pine blister rust has been an important feature in State and National Forests throughout the New England and Lake States, as well as in the northern Rocky Mountains and other parts of the West. This fungus affects northern white pine, western white pine and sugar pine.

rant and gooseberry) and the five-needle pines. Control of this disease in the East has proved to be both possible and practicable.

4. A large group of fungi are responsible for decay in living trees and structural timber. Probably those fungi belonging to the family Polyporaceae cause the greatest amount of damage. The Division of Forest Pathology of the Bureau of Plant Industry in the U. S. Department of Agriculture is actively engaged in studying and combating the diseases of forest trees, shade trees, and ornamental shrubs, as well as the decay and discoloration of structural timbers and other 
forest products. The latter phases of the subject are actively carried on at Madison, Wisconsin, in connection with the U. S. Forest Products Laboratory. The Division of Forest Pathology also maintains branch offices at San Francisco, California; New Haven, Connecticut; New Orleans, Louisiana; Albuquerque, New Mexico; Wooster, Ohio; Portland, Oregon; Philadelphia, Pennsylvania; and at Edinburgh, Scotland.

5. The Dutch elm disease or Graphium disease of elm is caused by a recently introduced fungus. It was first discovered in America in Ohio during 1930 and since that time has been found on elms in New York, New Jersey, Connecticut, Maryland, and Indiana. It is caused by a fungus which lives in the sapwood of the elm tree. It constitutes a most serious menace to all native elms and was probably introduced into this country from Europe on elm logs along with elm bark beetles which are instrumental in disseminating the fungus. The disease is evident largely through the wilting and death of the leaves which may occur gradually or quickly, depending upon the severity of the infection. After the leaves have wilted and dropped, the bark begins to dry and crack. A brown discoloration occurs in the sapwood. A federal laboratory has been established at. Morristown, New Jersey, known as the Dutch Elm Disease Laboratory, where diagnosis is made of diseased twigs or those suspected of infection. Several thousand elm trees have been found with Dutch elm disease in the three states Connecticut, New Jersey, and New York. All trees known to be affected with this disease in New York are removed and destroyed.

6. A recently discovered disease of beech now threatens to destroy the beech forests of northeastern United States. The disease is a bark injury caused by a fungus known as Nectria. It eventually causes the death of the affected trees.

Many other varieties of fungi attack living, dying, or dead trees and various forms of forest products. The life history of each kind must be carefully studied and understood before adequate measures may be recommended and adopted to combat it. Years of research are sometimes necessary, as in the case of the white pine blister rust. Many of these diseases have been introduced from foreign countries where they may be of less serious nature. A plant quarantine service has been established to examine carefully doubtful forms brought to this country from abroad and to exclude undesirable or dangerous ones.

The rate of decay of lopped tops and other slash left after logging operations has a very important bearing upon the fire hazards on the 
area, the condition and improvement of the soil for reproduction, and growth rate of the stand. Decay in hardwood logs left on landings or decks during warm weather is also an important phase of the subject. Recent investigations have added to the knowledge of the proper chemicals to use in preventing sap stain on pine, gum, and yellow poplar lumber cut in the South.

\section{DOMESTIC ANIMALS}

The grazing of cattle has done considerable damage to forests, particularly to hardwood reproduction and young growth in farm woodlots of the Ohio and Mississippi Valleys. Horses, sheep, swine, and goats may also inflict considerable damage on the forests through over-grazing or in other ways. Swine frequently dig up the young, fresh, succulent roots of longleaf pine in the South and destroy much reproduction.

Throughout the Rocky Mountains and parts of the Pacific Coast forests, open forest types such as ponderosa pine and aspen furnish excellent forage for cattle, horses, and sheep and concurrently, if properly controlled, may provide good wood crops.

The Forest Service estimates that approximately 246,000,000 acres of commercial forests are grazed every year. This means that substantially one-half of our total commercial forests are grazed. The largest percentage of forest grazing is in the South, where $67 \%$ is subject to grazing, chiefly by cattle.

The pasturing of woodlots in some sections, as in Ohio, Indiana, and Michigan, has destroyed much young growth and reproduction. Over-grazing may have serious effects upon the soil as well as upon prospective reproduction and young growth. Grazing in some regions tends to keep down the grass and therefore lower the hazard from forest fire. In Ohio woodlots, the returns from timber growing are estimated at several times the returns from pasturing livestock in the same areas, according to Tillotson. In the California pine region, the value of timber growth per acre per annum is estimated at $50 \mathrm{c}$ per acre contrasted with $15 \mathrm{c}$ or less per acre for grazing on the best areas, according to Show and Kotok.

\section{WILD ANIMALS}

Many animals which use the forests as their native habitat may cause considerable damage to the forest. Deer may do much harm to small trees and reproduction by eating not only the leaves but also 
small twigs and buds. In the Kaibab National Forest in Arizona and in portions of Pennsylvania deer have done so much harm to the forest that permission has been granted to shoot does or to reduce the deer herds. Beavers do considerable damage by girdling or felling trees, chiefly the poplar and aspen groups. They may destroy an entire stand adjacent to their dams by raising the water level and flooding timbered areas. This has occurred in parts of the Rocky Mountains and in the Adirondacks in New York.

Porcupines gnaw and girdle the bark of standing trees, particularly in lodgepole pine in the Northern Rocky Mountains and in the Lake States. Rabbits eat buds and small branches and even the bark of some species. In England, rabbit hunts are frequently conducted prior to the reforestation of many areas. Squirrels eat seeds and fruits, as well as young shoots and buds. Pike, in 1934, reported that squirrels girdled the main stems of ponderosa pine trees at 10 to 20 feet from the tops of trees, 4 to 7 inches in d.b.h. Mice have eaten considerable quantities of seed, particularly those stored in nursery warehouses. They also gnaw and destroy the bark of seedlings and young trees. Birds have caused relatively little damage. In fact, they contribute very helpfully by destroying large quantities of insect enemies. Birds also aid in the dissemination of seeds, particularly on burned areas, and on old fields in the South and East.

\section{SAND DUNES AND MISCELLANEOUS}

Sand dunes have done considerable damage, particularly along the Pacific, Atlantic, and Gulf Coasts, in several sections of the Rocky Mountains, notably in Colorado, as well as along the shores of the Great Lakes and in other sections. France has expended millions of dollars for the fixation of sand dunes and prevention of shifting sands, notably in the Landes region of southwestern France, where a veritable desert waste was converted into a profitable forest and a prosperous settled section.

Erosion has come to be considered a national problem. Both sheet and gully erosion have inflicted enormous damage in many parts of the country. This subject is briefly described in connection with the work of the Soil Conservation Service. Avalanches, landslides, and floods have been very destructive in restricted localities. Forest.fires have added to the injuries inflicted by these phenomena. Extreme cold, especially sudden drops in temperature, has caused frost cracks in many sections in the northern part of the country. These are long splits in the stems of trees resulting from the rapid contraction of the 
wood due to sudden and severe cold. They are sometimes followed by long, projecting ribs, called frost ribs. Hardwoods with large medullary rays, such as oak, beech, and sycamore, are especially susceptible, as also are elm, ash, and chestnut. Other phases of forest protection include damage by wind and ice storms and the theft of timber from

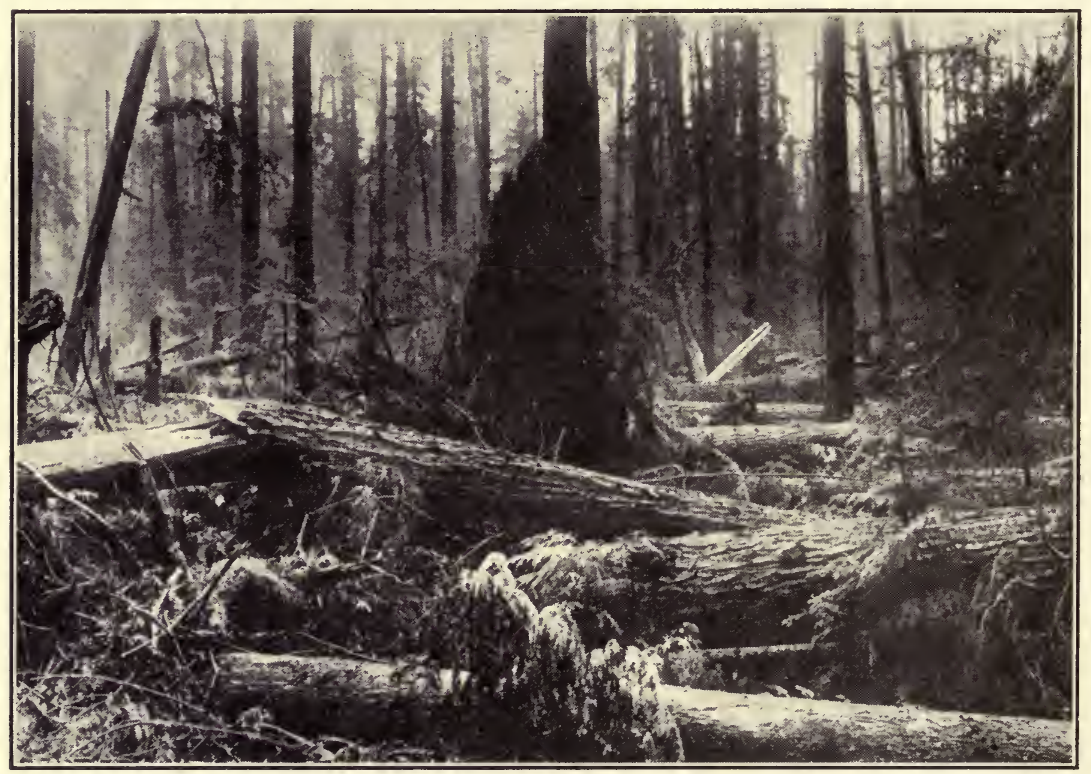

Fig. 46.-The greatest fire trap in the history of the United States. Billions of feet of Sitka spruce and western hemlock were windthrown by a tornado on the Olympic peninsula, Washington.

the forest by mankind. Properly marked and established boundaries are the best preventive for theft, which is usually unintentional. Many damage claims have been made by federal authorities as well as by private agencies as a result of the illegal cutting and logging of areas in some parts of the country. 


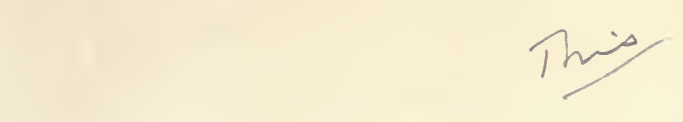

\section{CHAPTER VII}

\section{FOREST MENSURATION *}

\section{GENERAL}

Forest mensuration is that branch of forestry which has to do with the measurement of the contents of standing timber, felled trees, and logs, and the calculation of rate of growth and future yield. It is important to determine the amount and volume of standing timber for the conduct of logging operations and plans of forest management. For the purchase, sale, and exchange of standing timber, an appraisal of the amount and value of the timber is necessary. A study of growth is essential to estimate the future yields of planted or naturally grown forests. Until recently, timber tracts were frequently sold for a lump sum. With the rising value of timber and forest products, a more scientific method of determining values has become necessary.

Standing timber is referred to as timber, stumpage, merchantable timber, or by various other terms. The determination of the amount and value of standing timber is often known as timber estimating, cruising, and land-looking.

\section{UNITS OF MEASURE}

The units of measure of timber generally used are the board foot, the cubic foot, and the cord. The board foot is the unit of measure of lumber; it consists of a board $1^{\prime}$ square and $1^{\prime \prime}$ thick. A cord is a stack of wood $8^{\prime}$ long, $4^{\prime}$ high, and $4^{\prime}$ wide, and is used in measuring pulpwood, fuelwood, acid or chemical wood, and many other forms. A cord contains 128 cubic feet gross measure, and from 70 to 100 solid cubic feet of wood, depending upon the size and shape of the individual pieces. In some parts of the country, as in the southern

* Because of the necessity for brevity, this subject is treated in a very elementary manner. For an extended treatment of the subject, see "Forest Measurement" by H. C. Belyea, John Wiley \& Sons, New York, 1931; "Forest Mensuration" by Chapman and Demeritt, J. B. Lyon, Albany, N. Y., 1932; and "Forest Mensuration" by Bruce and Schumacher, McGraw-Hill Book Company, New York City, 1935. 
Appalachians, cordwood cut for pulpwood, fuelwood, or distillation purposes is generally cut to $5^{\prime}$ instead of $4^{\prime}$ lengths, thus making a cord 160 cubic feet, gross measure. A face cord is one which is $\mathbf{8}^{\prime}$ long, $4^{\prime}$ high, and made up of pieces $12^{\prime \prime}$ to $20^{\prime \prime}$ or more long. It is generally used for measuring stove, fireplace, or furnace wood.

The following are the equivalents generally recognized in forestry practice.

\begin{tabular}{lccc}
\multicolumn{1}{c}{ Units } & Siże & & Equivalent in Board Feet \\
1 cord of wood & $4^{\prime} \times 4^{\prime} \times 8^{\prime}$ & $=$ & 500 \\
1 railroad tie & $7^{\prime \prime} \times 9^{\prime \prime} \times 9^{\prime}$ & $=$ & $331 / 3$ \\
1 cubic foot & & $=$ & 4 to 8 \\
1 post & $4^{\prime \prime} \times 5^{\prime \prime} \times 7^{\prime}$ & $=$ & 3 \\
1 pole or pile & $8^{\prime \prime}$ top $\times 35^{\prime}$ long & $=$ & 100 \\
1 converter pole & $4^{\prime \prime}$ top $\times 20^{\prime}$ long & $=$ & 10 \\
6 pieces lagging & $3^{\prime \prime}$ top $\times 20^{\prime}$ long & $=$ & 10
\end{tabular}

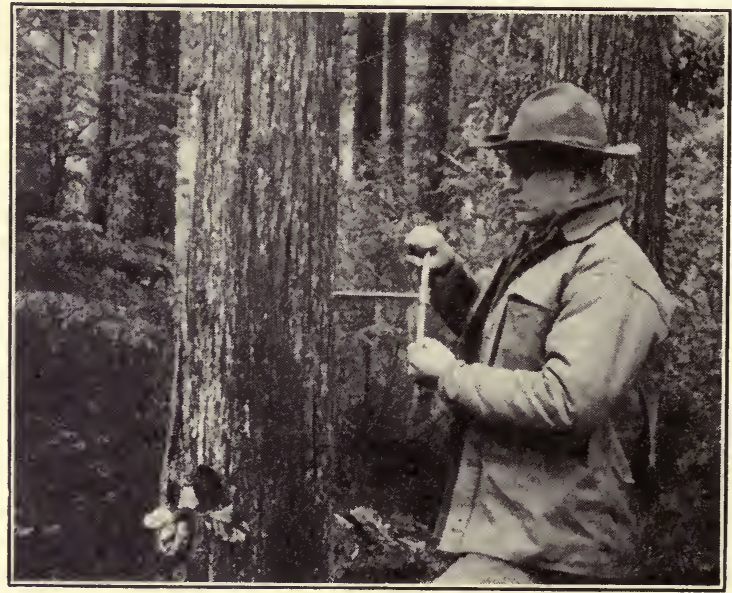

Fis. 47.-A forester determining the age of a tree with an increment borer. A radial section taken across the annual growth rings discloses the age as well as the rate at which the tree is growing at different periods of its life. Well managed stands may grow at the rate of 200 to 1000 board feet per acre or more per annum.

\section{INSTRUMENTS COMMONLY USED}

The principal instrument for measuring diameters of standing timber is the caliper. The diameter tape and the Biltmore stick are also used. Diameters are measured at breast height or $41 / 2^{\prime}$ above the ground. For measuring heights, instruments known as hypsometers are employed. Tapes and poles are used for measuring lengths of 
fallen trees and for laying off log lengths. Instruments for measuring the volume of saw logs or of sawn lumber and timber are known as scale sticks. Instruments for determining the age and growth of trees by taking a sample core of wood in a radial direction to the center of the tree are known as increment borers.

\section{LOG RULES}

Log rules are tables showing the contents in board feet of logs of different top diameters and lengths. The most common log rules are the Doyle, Scribner, and the International rules. The Spaulding rule is widely used on the Pacific Coast and is especially adapted to largesize timber.

Some rules have official status. For example, the Doyle rule is the official log rule for Louisiana, Florida, and Arkansas. The Scribner rule is the official rule in Minnesota, Idaho, Wisconsin, and West Virginia. It is also the official rule used in timber sales and for other purposes by the U. S. Forest Service.

Log rules are computed on the basis of a formula or by diagram. Excellent rules are based upon experience, that is, by taking actual tally of the output of lumber from the different size logs.

\section{SCALING}

Scaling consists of the measurement of logs by a given log rule or $\log$ scale. It is generally done by one man using a scale stick to measure the width of the small end of the $\log$ inside the bark and tallying the log contents in board feet as determined by the reading on the $\log$ scale and the length of the log. If logs were truly cylindri-

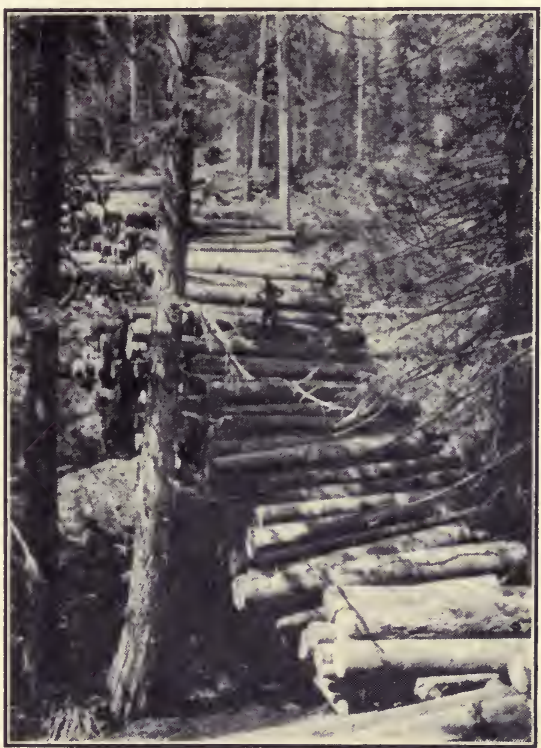

Fig. 48.-Scaling a deck of logs at head of chute shown in immediate foreground. Scaling of the logs decked in this fashion is difficult because of the irregular location of the ends of the logs. Northern Rocky Mountains. cal, symmetrical, and straight, and contained no defects such as rot and decayed knots, scaling would be a very simple operation. Scaling is generally done on a log deck or landing in the woods and is used 
not only to determine the board-foot contents of logs but also to measure pulpwood, fuelwood, shingle bolts, distillation wood, poles, piling, cross ties, cooperage bolts, and many other forms of forest products. A timber scaler must be experienced in sawing lumber at the mills in order to estimate the proper deduction to be made for interior defects, such as splits, heart checks, ring shake, butt or heart rot, and pitch streaks. He must also be able to make proper deduction for crook and crotch defects, unsound sap, cat faces, worm holes, lightning scars, frost checks, pitch seams, and other defects which may occur.

The accuracy of scaling is very largely dependent upon the experience and skill of scalers.

\section{VOLUME TABLES}

A volume table is one which shows the contents in board feet, cubic feet, or other units for a given species of different sizes. For example, from a volume table one may quickly determine that a tree $18^{\prime \prime}$ in diameter and $120^{\prime}$ high contains a stated number of board feet. There are several different kinds of volume tables.*

\section{CRUISING}

Cruising, timber estimating, or land-looking are the terms commonly used in woods parlance for determining the volume and value of standing timber. A timber cruiser may also make topographic maps used for logging and management plans. For many years, woodsmen of considerable experience were employed, and they generally did a very efficient job. But as timber values rose, a more scientific method became necessary. At first, rough approximations were followed. With low stumpage values, these were sufficiently accurate. In no case, except on the smaller tracts, is all the standing timber actually calipered or measured for height, diameter, and number of trees per acre. Generally a small percentage of the total area is carefully measured and recorded in a tally book. Timber estimating or cruising may be done by ocular or systematic methods. An experienced woodsman can very accurately determine with his eye the diameter and height of individual trees and make a very close estimate of the number of board feet per acre in a given stand. Ocular estimates are still used to some extent. A more accurate and systematic form is actually to measure the height and diameter of all the trees on

* For further description and analysis, consult the texts referred to. 
a given strip, generally one or two chains wide, or on a sample plot. The volume secured from accurately measuring the small sample (generally from 3 to $20 \%$ or less) in this way is applied to the entire tract in order to obtain the total volume. For example, if by cruising a tract, the sample plot or strip shows 5000 b.f. per acre and there are 10,000 acres, the total volume on the tract will be $50,000,000$ b.f. Measurements of growth are made and applied in the same way. If

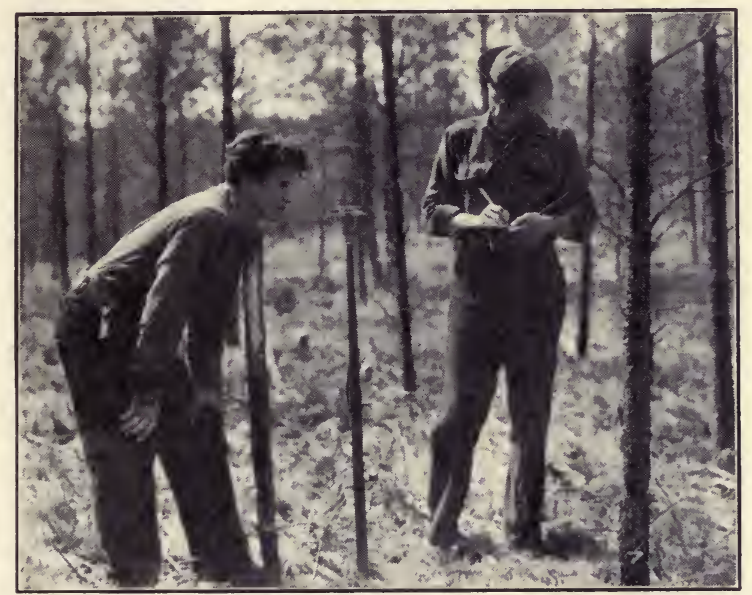

Frg. 49.-Timber cruising in a pine forest. The compassman on the left sights through the instrument and the tally man on the right measures, counts and tallies the trees to be recorded in his notebook. Thus a sample area is measured, and from it the total number of trees, volume of the stand in board feet, etc., are determined.

the growth rate is 500 b.f. per acre per year, the annual growth on this tract would be $5,000,000$ b.f.

\section{YIELD TABLES}

Yield tables are used to predict the contents or volume of a forest at a specified future year. They are tables of the expected contents per acre of a forest growing on a specified site and managed in accordance with the most efficient methods. They may be based on three or more site qualities, and they may be applicable for pure or mixed, virgin or second growth, thinned or unthinned forests. Yield tables should be used only in the region where they have been constructed. Two kinds of tables are generally recognized, namely, the empirical and the normal tables. The normal table shows the yield for fully stocked stands, whereas empirical tables show the average 
stand per acre for the entire forest, regardless of whether it is fully or partially stocked. Yield tables are very valuable in preparing working plans or a plan of management for the future. They are widely and extensively used in Europe, particularly in Germany, France, and Switzerland, where intensive forms of forest management are economically possible. Nearly all National Forests operated for the production of lumber and other forest products, as well as for grazing and game, have very detailed management plans for future years.

\section{STUMPAGE AND STUMPAGE APPRAISAL}

Stumpage is the value of standing timber. The term may also be used to refer to the standing timber itself. Stumpage values steadily increased in this country until 1929. From 50 to 100 years ago, stumpage values of $\$ 1$ to $\$ 5$ per acre were common. As there may have been from 5000 to 40,000 or more b.f. per acre, these values represented from a few cents to a dollar per thousand board feet. Although lumber values may fluctuate widely and rapidly, stumpage values do not fluctuate with the same violence or rapidity. Stumpage values have fallen rapidly since 1929 . The high peak of lumber prices was in 1920. Stumpage values reflected to some extent the high lumber prices, but not in the same proportion.

Stumpage values may vary widely with the species, location, size of tree, accessibility, etc. The principal factors which determine stumpage values are as follows:

1. Species, Quality, Size, and Density of Standing Timber. White pine, white ash, and black walnut enjoy relatively high stumpage values. Tupelo gum, incense cedar, balsam fir, western hemlock, white fir, and beech are woods of relatively low stumpage values. Dense stands are more valuable than scattered or open stands. Trees which are free of knots, rot, checks, and insects, and which are straight, tall, and symmetrical, are much more valuable than those which are short boled, limby, tapered, and crooked. Virgin timber is generally worth much more than second-growth forest.

2. Accessibility. The distance from the market reflected in the costs of logging and transportation are vital factors bearing upon stumpage values. It is obvious that timber near a sawmill is much more valuable than that located many miles away, involving expensive forms of $\log$ transportation in order to place it on a competitive market. 
3. Demand on the Market. The kind of product and its salability have a very definite bearing upon stumpage values. Hardwoods are generally more valuable than softwoods. Demand reflected in prices is the most important single factor in determining stumpage values.

4. Form and Terms of Sale. Timber in farmers' woodlots is frequently sold by the lot rather than on the basis of thousand board feet. Flat sales for a lump sum should be avoided. Cash sales bring higher prices than those involving deferred payments. Sales should be made upon the basis of a mutually agreed upon log scale per thousand board feet in the woods or delivered at a given point.

5. Utilization and Silvicultural Considerations. If stumps are to be cut unusually low, tops to be taken to extreme limits, brush to be piled and burned, and if other fire protection measures are insisted upon, stumpage values may be lower than if the purchaser is free of these restrictions. Timber sales on National Forests command higher prices if the logger is not required to undergo additional expense to protect the young or remaining growth, leave seed trees, cut inferior species or poor specimens, and provide for fire protection by piling and burning the logging slash and débris. On the other hand, selective logging, as explained elsewhere, may be less expensive than clear cutting.

Stumpage values are determined by several different methods. One simple method is to determine the probable cost of logging and lumber manufacture including depreciation and overhead charges such as insurance, interest and taxes; then add 20\% to this total investment for profit and risk. These combined costs are then subtracted from the actual sales return from the lumber, the difference being the stumpage value. This is sometimes referred to as the realization value on many logging operations. When no profit is realized, there may be a minus stumpage value.

The species most commonly used in our lumber markets, namely southern pine and Douglas fir, command relatively low stumpage values. Douglas fir stumpage is generally sold for $\$ 1.50$ to $\$ 3$ per m.b.f.; southern pine for $\$ 3$ to $\$ 5$; virgin longleaf pine, $\$ 5$ to $\$ 10$; ponderosa pine, $\$ 2.50$ to $\$ 3.50$; Idaho or western white pine, $\$ 5$ to $\$ 7$; sugar pine, $\$ 4$ to $\$ 6$; northern white pine, $\$ 5$ to $\$ 10$; white oak, $\$ 5$ to $\$ 8$; yellow poplar, ash, or cherry, $\$ 6$ to $\$ 10$; western hemlock, $\$ 1$; eastern hemlock, $\$ 1.50$ to $\$ 4$; yellow birch and hard maple, $\$ 3$ to $\$ 6$; cypress, $\$ 5$ to $\$ 10$; eastern spruce, $\$ 3$ to $\$ 5$; and western spruce, $\$ 3$ to $\$ 5$.

The U. S. Forest Service and several state forest services sell stumpage to private operators under carefully worded timber sale 
contracts to insure the reproduction and sustained yield of the forest. Bids are invited after public advertising, and the sale is awarded to the highest bidder. Many lumbermen cut timber from both private and federal properties to supply their log requirements at sawmills. Recently few sales have been made from National Forests because the lumber markets have been generally flooded with an adequate supply of privately owned timber for many years. 


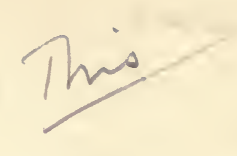

\section{CHAPTER VIII}

\section{SILVICULTURE-METHODS OF NATURAL REPRODUCTION *}

\section{DEFINITION AND GENERAL CONSIDERATIONS}

Silviculture is the art of producing, reproducing, and tending the forest. It is the business of growing trees, as contrasted with the business of using them (utilization). The two are inseparably interdependent and interwoven in the practice of forestry. In the opinion of many foresters, silviculture includes forest protection, as that is a part of growing and tending a forest.

As indicated above, forests are reproduced by: (a) seeds; (b) sprouts from the stump or root suckers; and $(c)$ cuttings. These are the very foundations of the various methods of reproducing the forest by natural means.

Silviculture is based upon silvics, which includes the fundamental laws of growth and development of single trees and of the forest as a biological unit. The purpose of silviculture is to produce the highest returns both in quality and quantity on a given area within a stated length of time. This purpose, however, may depend upon the wishes of the owner of the timberland. He may desire to improve the hunting and fishing facilities or the grazing or scenic conditions concurrently with wood production. However, the usual primary objective of silviculture is wood production.

The province of applied silviculture may include:

1. Methods of naturally reproducing a forest-silvicultural systems.

2. Methods of artificial reproduction (generally known as reforestation or tree planting).

3. Methods of treating a growing forest to improve its quality, growth rate, and composition.

Intensive silviculture as practiced in Europe is not possible generally in the United States because of our unfavorable economic con-

* Based largely upon "Practice of Silviculture" by R. C. Hawley, John Wiley $\&$ Sons, New York, 1935. For enlargement and further expansion of the subject refer to this book. 
ditions. An initial experimental form has been tried out and successfully applied, however.

The costs of silviculture as outlined by Hawley depend upon: (1) Cost of securing reproduction either by artificial or natural means. (2) Cost of protection from injury. This may be a few cents per acre yearly. Forest fire insurance may be classed as a silvicultural cost although not available as yet. It seems likely that insurance may come when improved methods of protection are in effect. (3) Increased expenses of logging. Greater care in felling, bucking, and skidding logs to protect or save young trees and seedlings on the cutting area. Horse skidding is much less destructive to young growth than other forms of skidding. Tractor logging is much less destructive than power skidding. (4) Increased cost of administration, such as marking of trees for felling, inspection, and general supervision. (5) Costs, if any, due to permanent investment.

Show, ${ }^{*}$ of the U. S. Forest Service, has indicated that the increased cost of silviculture in the California pine region would not be over 50c per m.b.f. cut. Munger $\dagger$ estimated it would cost 1c per acre annually, plus $22 \mathrm{c}$ per m.b.f. for logs cut, in order to assure continuous forest production in the Douglas fir region of the Northwest. Cline and Lockard $\neq$ estimate a loss of $6 \mathrm{c}$ per acre per annum in the first rotation (age of a forest when cut) of 60 years in mixed white pine and hardwoods in Massachusetts and subsequently a net profit of $\$ 6.29$ per acre.

\section{ADVANTAGES OF NATURAL VERSUS ARTIFICIAL REPRODUCTION}

These advantages may be summarized as follows: (1) Natural reproduction is generally far less expensive than tree planting because it costs little if anything. Even with seed trees left for purposes of securing reproduction, this method may be very inexpensive and certainly far less expensive than growing trees in nurseries, shipping them to the planting area, and planting them in the field. (2) It is nature's method. Trees readily adapt themselves to the site. There is often danger that planted trees may not be properly suited to a given locality, and even on a given planting area some trees are

* Show, S. B., "Timber Growing and Logging Practice in the California Pine Region," U. S. Dept. Agr. Bull. 1402, pp. 70-71, 1926.

$\dagger$ Munger, T. T., "Timber Growing and Logging Practice in the Douglas Fir Region," U. S. Dept. Agr. Bull. 1493, pp. 32-34, 1927.

$\$$ Cline, A. C., and C. R. Lockard, "Mixed White Pine and Hardwood," Harvard Forest Bull., 8, pp. 57-58, 1925. 
better suited to certain sites than others. Nature takes care of these variations in soil, site, and moisture conditions.

\section{SILVICULTURAL SYSTEMS}

Silvicultural systems may be briefly described as follows:

1. Clear-Cutting Methods. The forest is cut clear and reproduction obtained $(a)$ from seeds naturally distributed from adjoining areas, $(b)$ from seeds on trees prior to or during felling, $(c)$ by planting, or $(d)$ by a combination of the above methods. Sufficient seed

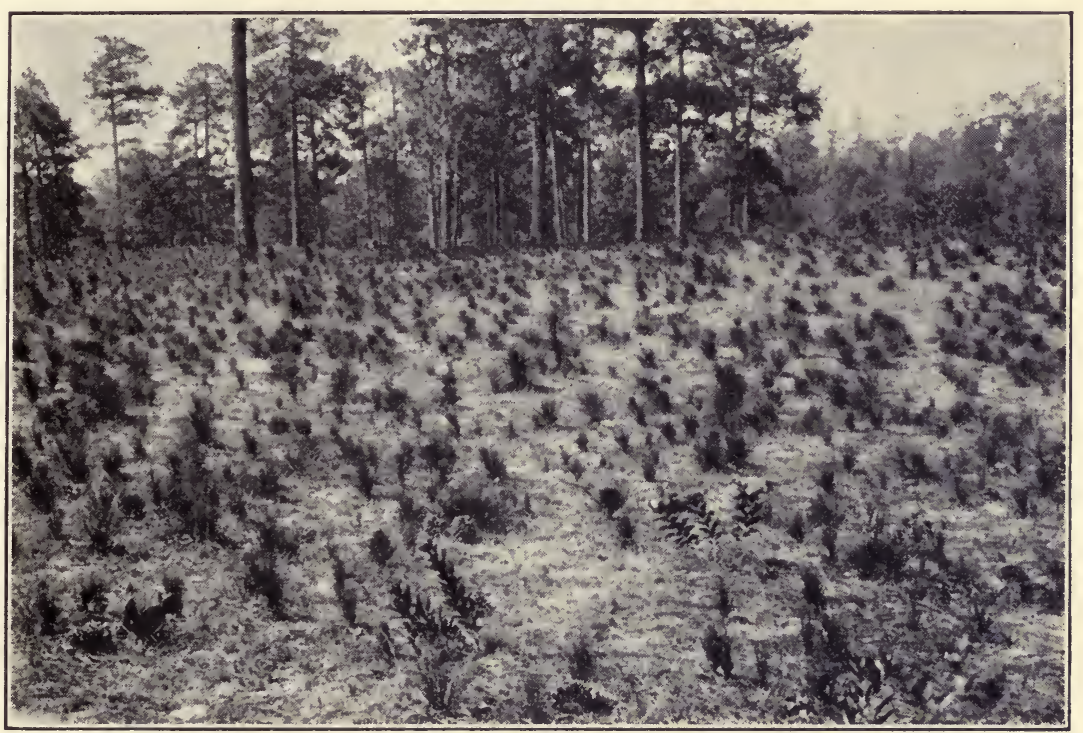

Fig. 50.-Excellent longleaf pine reproduction secured from adjoining seed trees on tract near Aiken, South Carolina.

may be in the soil or on the trees felled during the logging of the area. Large quantities of trees frequently grow up after logging or even after a fire. This has been notably true of lodgepole pine and Douglas fir in the West. The former tree retains in its cones seed for several crops for a number of years. Clear cutting in strips, alternate strips, groups, or progressive strips may be used. It is adapted primarily for over-mature and mature timber of large size. These stands should be cut clear for both silvicultural and financial reasons. Logging of mature, even-aged stands may be considerably cheaper by this method, and losses from windfall are avoided. Even-aged forests are produced by this method. 
2. Seed-Tree Method. A given portion of the forest is cut clear except for seed trees left singly or in groups for furnishing seed to restock the area naturally. This method may be combined with method 1 just described. It is applied to and results in even-aged forests represented by ages within a range of 10 to 20 years. After natural regeneration is secured and the little trees develop, it may

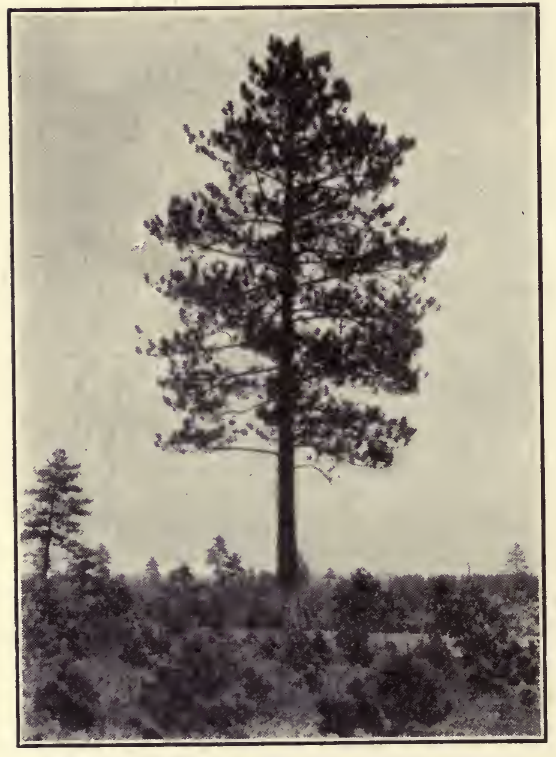

Fig. 51-Illustration of clear cutting with individual Norway pine seed trees. Huron National Forest, Michigan. Excellent reproduction secured from the mother trees.

Hampshire at least one $10^{\prime \prime}$ wind-firm white pine tree of good crown must be left on each acre cut of this species. The seed-tree method is applied generally to the entire southern pine region. It is also used in many sections of the West.

3. Shelterwood Method. This involves the removal of the stand by a series of partial or progressive cuttings. Natural reproduction starts under the protection of the older trees. By careful cuttings, the crowns are enlarged and seed production is stimulated. When a good young growth is established on the forest floor, the last trees in the stand are finally removed. It is adapted to even-aged stands. Reproduction cuttings may extend over a period of 40 to 60 years. The regeneration period is generally between 10 and 20 years. As the 
name implies, reproduction is obtained under the shelter of a progressively cut stand. This shelter gradually becomes a hindrance to the growth of the new forest. Under a simple form of application, only two cuttings are required, whereas under an intensive form, several cuttings up to 10 or more are made. Various forms, such as the uniform method and the strip and group shelterwood methods, are followed.

This system is widely used in Europe, especially with oak, and sometimes with spruce and pine. One of the best municipal forests

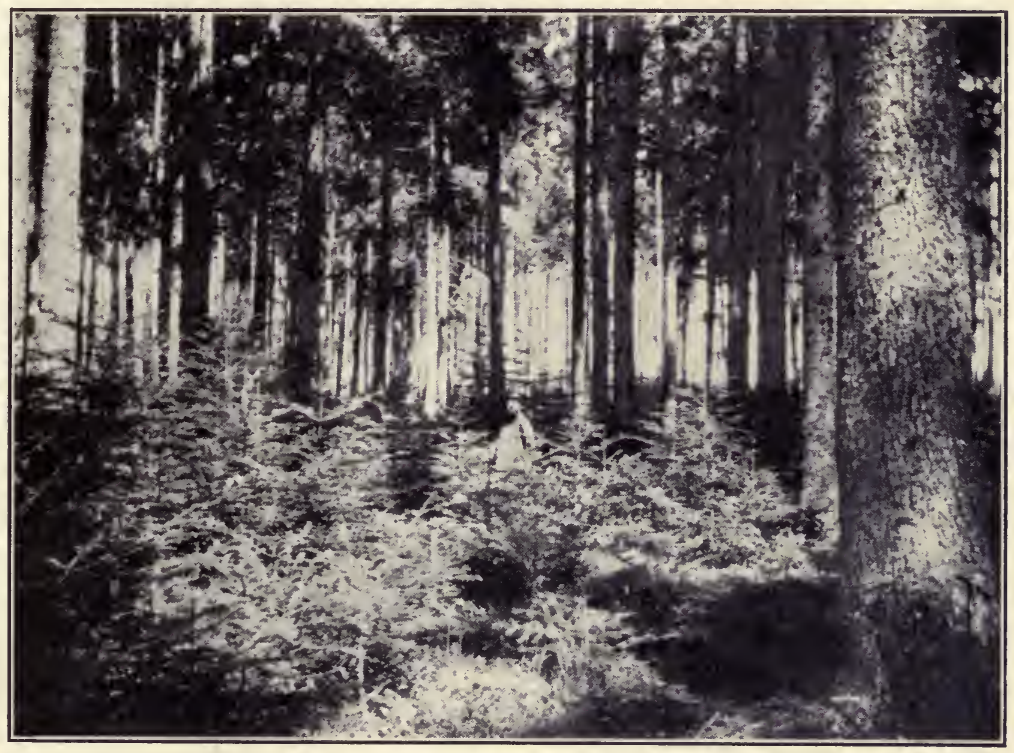

Fig. 52.-Illustrative of the group shelterwood system of naturally reproducing forests. This is an intensive system of silviculture whereby reproduction is secured under the over-wood through a gradual system of thinnings and reproduction cuttings. Photo by author in the Black Forest of Germany. The species are Norway spruce and silver fir.

in France, located at Epinal, is handled by this system. It is readily applied to heavy-seeded species, such as oak, as well as to those of light-weight seeds. An excellent market should be available for the various cuttings. Logging is generally much more expensive because so many fellings must be made on the same area in the frequent thinnings. Reproduction is generally more complete and certain than with other natural methods. It should not be used with trees easily wind-thrown. Great technical skill is required for successful consummation because of the delicacy in marking the right trees at the 
right time to open up the crown cover, stimulate seed production, and prepare the soil for seed germination. It can be applied in this country to oak, white ash, and white pine where market conditions are favorable. It is especially applicable to parks and estates where aesthetic effects are desired. It is used in the South, in the Black Hills of South Dakota, in New England, and in the Douglas fir region in the Rocky Mountains.

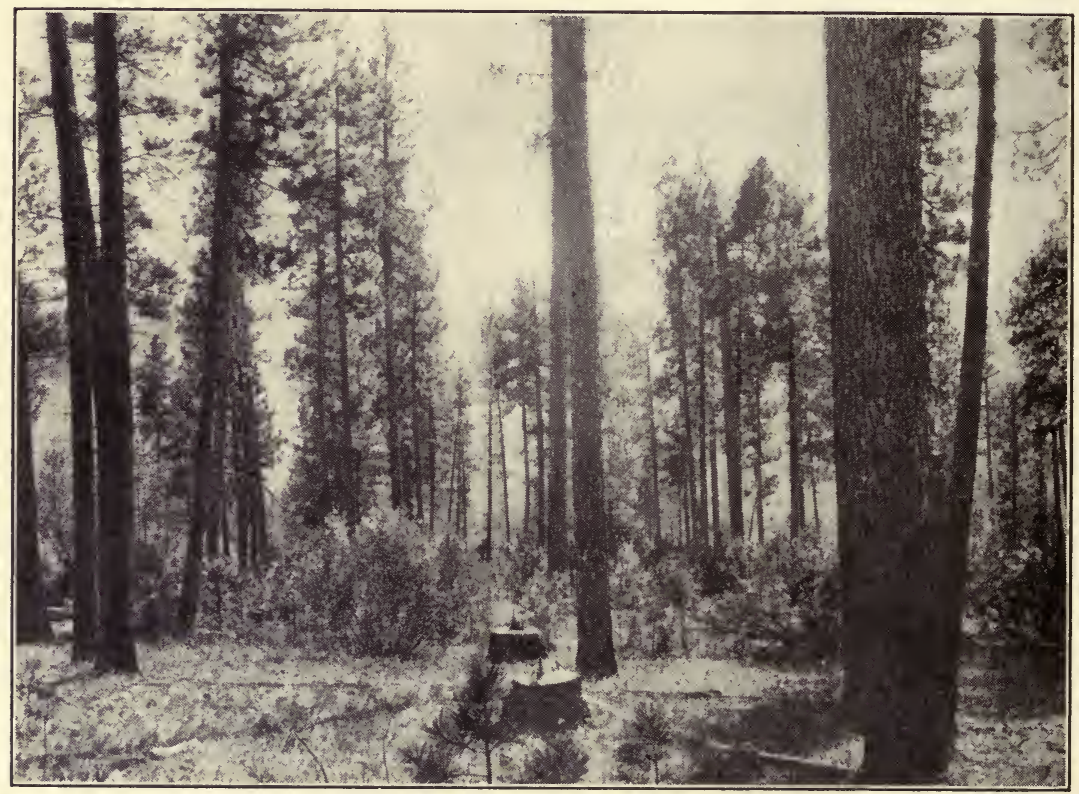

Fig. 53.-Photo taken approximately 20 years after area was selectively logged, the slash was carefully piled and burned and the area protected from fire. There is excellent reproduction of young growth on the ground and there is much more rapid growth attained in the remaining trees through the opening of the crown canopy and giving more light to the remaining trees. Stumps were cut low and close utilization was practiced. Photo taken in ponderosa pine stand in western Montana.

4. Selection Method. By this method, the oldest and largest trees in the stand are selected for cutting. Single trees or groups are cut. The stand is never completely clear cut during logging operations. A typical and continuous uneven-aged forest is grown. All ages are represented, generally from seedlings to nearly mature trees. It is best adapted to tolerant or shade-enduring species. A cutting is made each year or at regular periodic intervals under intensive forms of application. If cuttings are at frequent intervals, logging may be very 
expensive; if at long intervals, logging may be relatively inexpensive. These cutting cycles may be 10 to 60 years apart, in the United States; they generally are less than 10 years apart in Europe. Such modifications as strip selection, group selection, and area selection may be followed. It is the basis of selective logging introduced and used within recent years and described later in the text.

The selection method is likely to be best adapted to general silvicultural and economic conditions found in this country. It is simply and inexpensively applied. Individual trees are generally marked for cutting. It permits wide flexibility in diameter limits of individual trees as well as in areas or age classes to be logged. Reproduction is easily secured, the forest site is constantly protected, and there is less danger of fire than by some other methods. Sometimes problems of brush disposal may be difficult. It is the method chiefly used in the National Forests, and it is being introduced on many private holdings, notably of the Goodman Lumber Company in Wisconsin; the Camp Manufacturing Company at Franklin, Virginia; Weyerhaeuser Timber Company and the Potlatch Forests, Inc., in Idaho; the Crossett Lumber Company at Crossett, Arkansas; and in many other locations.

5. Coppice Method. This is applied generally to hardwoods which sprout readily from the stump when the tree is cut. An even-aged stand is produced. Trees are generally clear cut, as on chemical wood cuttings in southeastern New York and northern Pennsylvania. Low, sloping, even stumps should be cut, and the felling should be done with the axe. Trees under 30 years of age sprout with the greatest vigor and rapidity of growth. The system is best applied on short rotations of 10 to 40 years. Some of the most profitably managed forests in the world are the sprout chestnut forests in Italy near Rome. Coppice growth is often supplemented by seedling reproduction, either naturally or artificially (planting) applied. Pollarding is the cutting of the top of trees at 4 to 12 feet above the ground to obtain small sprouts. In Europe, rotations are sometimes 1 year in duration for willow rods for basketware; 5 to $\mathbf{1 5}$ years for cooperage hoops, mine props, charcoal, etc.; and up to 40 years for fuelwood. Much of the hardwood forests of France and Italy are managed for fuelwood on 20 -year rotations. Redwood sprouts vigorously and frequently forms second-growth stands after the virgin timber is logged. Combined coppice and seedling forests are sometimes maintained in Europe. This is a composite of sprouting and other cultural methods of reproduction previously described. 


\section{AMERICAN VERSUS EUROPEAN SILVICULTURAL SYSTEMS}

Silviculture is a recognized art and is commonly practiced in Europe. According to Hawley, relatively little is known about American silviculture. This is attributed to three very definite causes, as follows:

(a) Silviculture has been practiced to a very limited extent, owing to unfavorable economic conditions and paucity of knowledge of the subject. It requires several decades of experimental work to arrive at a definite silvicultural process as applied even to a single species.

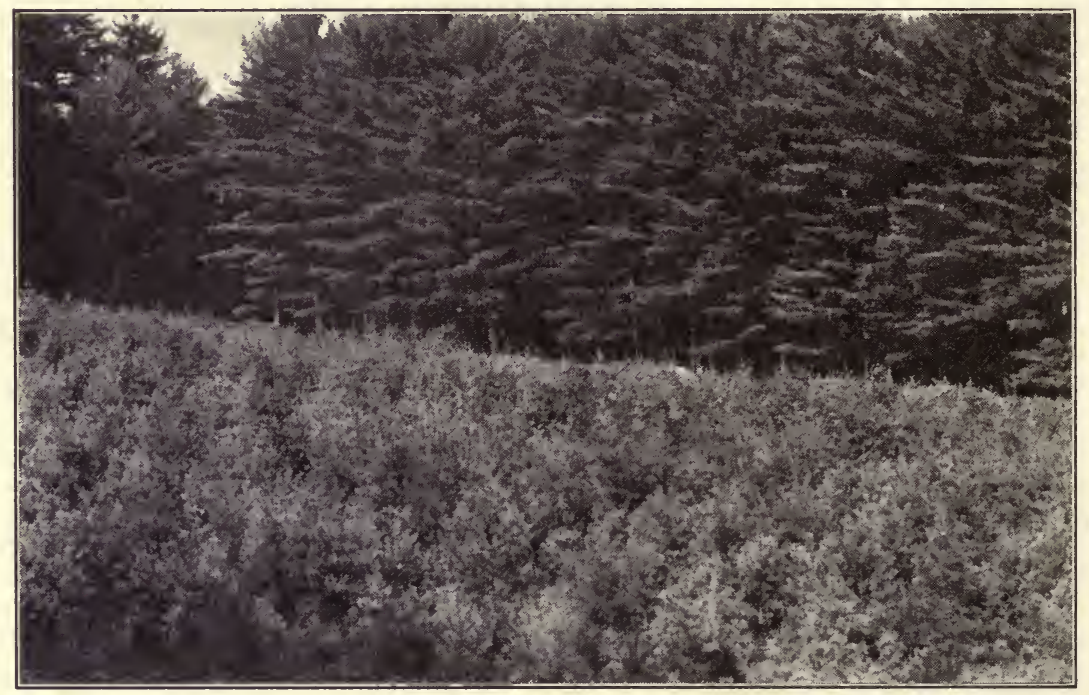

Fig. 54.-Perfect white pine reproduction naturally seeded on pasture land. Seed woods on three sides. Cheshire County, New Hampshire.

(b) Silvicultural practice is essentially a local problem, varying even between local forests in the same region. Knowledge of the subject develops slowly under such conditions, and several rotations must be used before much experience is acquired.

(c) The application of the knowledge gained by experience in the treatment of a forest is difficult when such knowledge is only fragmentary. Silvics, which is the basis of silviculture, is still in its infancy, as far as furnishing definite information for the use of practitioners.

Trees found in America are quite different from those in Europe. There is a very much larger number of good commercial species in 
this country in comparison with the relatively few in Europe. A new and definite type of American silviculture, which seems likely to revolve around selective logging, must be developed. It will have distinctive and original features, although European practice may point the way. We cannot, in this country, directly apply foreign intensive theories of management until higher prices for forest products are obtainable and we know more about the art of growing trees.

\section{SILVICULTURAL SYSTEMS OF CUTTING SOME REPRESENTA- TIVE TYPES IN THE NATIONAL FORESTS*}

It is the standard Forest Service practice in harvesting timber from the National Forests, if conditions permit, to follow silvicultural systems which provide for partial removal of the stands. If the condition of the stand, due to age, composition, or damage, does not lend itself to such systems, it occasionally -becomes necessary to resort to some form of clear cutting, but with ample provision made for seed trees.

The different forest types naturally overlap in many instances, but the following types are generally distinctive and are selected as representative in the management of the National Forests.

Ponderosa pine-Rocky Mountain and Pacific Coast States.

Western white pine-Northern Rocky Mountains.

Douglas fir-North Pacific Coast.

Engelmann spruce-Rocky Mountains.

Lodgepole pine-Rocky Mountains.

These brief descriptions illustrate very pointedly that the theoretical silvicultural systems as shown in Chapter 8 , section 3 , must lend themselves, in their application, to local conditions and circumstances. Often a combination of two systems is necessary.

Ponderosa Pine Type. This type lends itself admirably to a selection system of marking. It occurs in pure stands or in mixture with either white fir, Douglas fir, western larch, or sugar pine, or a combination of these species. The type usually has from one to three different age classes of ponderosa pine present and offers a rather simple problem in marking. The volume of timber reserved depends upon the availability of suitable trees and will vary from 20 to $50 \%$ of the total volume. An endeavor is made so to space the reserved timber that the individual trees may have optimum conditions for

* Supplied largely by J. A. Fitzwater, of the Office of Forest Management, U. S. Forest Service, Washington, D. C. 
growth. This often necessitates the thinning of young stands known as black-jack groups. In rather rare instances the entire stand is found to be over-mature and it becomes necessary to resort to clear cutting with the reservation of four to six seed trees per acre. In the Southwest, grazing must be closely correlated with time of cutting in order to assure reproduction. Good seed years are infrequent, and a combination of good seed years and reasonably wet summer seasons is essential for the establishment of new growth. Slash disposal is rarely a problem in this type; the method of disposal varies from lopping and scattering the slash with the breaking up of the area into control units, to complete disposal by piling and burning.

Western White Pine Type. Western white pine, though frequently found in pure stands, more often occurs in association with white fir, western hemlock, Douglas fir, western red cedar, Engelmann spruce, and western larch. All these associate species, with the exception of larch, are tolerant of shade. Since western white pine is rather intolerant of shade, some silvicultural system must be followed which approaches clear cutting. Partial opening up of the stand where a large proportion of the composition is made up of tolerants (shadeenduring species) merely encourages these species, and the continuation of such a practice results in a conversion to a forest of low-quality trees.

Three rather distinct conditions are found in the western white pine type, namely:

1. A two-storied forest of almost pure pine 80 to 140 years old; a condition usually resulting from ground fires.

2. A forest less than 200 years old, occurring either pure or in mixture with many tolerant species.

3. A forest 200 to 500 years old - the white pine climax typewhere all but a few large pines have passed out of the stand which is represented by old defective trees of western hemlock, western red cedar, white pine, and occasional western larch, in the order named. If the stand is not disturbed by fire, wind, insects, or the hand of man it will eventually become a pure stand of defective worthless hemlock.

Case 1 is the least common of the three conditions named. It can best be handled on what approaches a shelterwood system of cutting with the removal of about $50 \%$ of the stand. Such treatment results in rapid stimulation of growth in the reserved trees and an almost immediate restocking of white pine in the created openings. Slash is piled and burned. 
Case 2 is the most common condition met. The recommended treatment is to cut the hemlock, white fir, and over-mature cedar as closely as possible and leave from four to six white pine trees of merchantable size per acre. Occasionally a few small white pines are left. In some sections of the western white pine region the stands contain considerable understory of thrifty western red cedar. It is customary to take out such trees as will make a pole, 30 feet long with an 8-inch top or larger, and to reserve the trees under this size for further growth. If the stand is of such character that it becomes necessary to open it severely, these understory cedars are very apt to sun-scald and become worthless. Usually many of the hemlock and white fir trees are defective and must be felled; often neither of these species will justify the cost of logging and milling and must therefore be left in the woods, even if sound. It is absolutely necessary that the stand be opened up sufficiently to give satisfactory conditions for white pine regeneration. If it is not opened up sufficiently the tolerant inferior species will capture the site, and it is therefore often necessary to fell and leave much hemlock and white fir in the woods even though sound. Slash is piled and burned.

Case 3 is met with much more often in private cuttings than in National Forest operations, since it occurs on the better sites and was alienated early in the competition for timber lands. If in an advanced stage, there is nothing to do but cut the stand clean and plant. All the merchantable timber is removed, and all remaining trees, except larch (if left because of lack of market), are felled. The area is then surrounded by fire lines and just as soon as conditions will permit in the fall is burned broadcast. The object is to get as clean a burn as possible and yet keep the fire within bounds. The area is then planted to western white pine.

Douglas Fir Type-Pacific Coast. This type offers one of the most difficult silvicultural problems of the Forest Service. Practically the entire stand consists of species tolerant of shade, with Douglas fir, the most desired species, the least tolerant. The stands operated in the past have been largely old stands, mature and over-mature and not of a character to lend themselves to a selection system of cutting which will favor Douglas fir, the most-desired species. In other words, selective cutting has a tendency to "high-grade" the forest and leave a stand of inferior species which will largely control the composition of future crops. The principal species in mixture are Douglas fir, western hemlock, white fir, western red cedar, and Sitka spruce; the last two species are not always present. Another factor which it has been 
necessary to consider is the great risk of windfall in any approach to a selection system of cutting. Experience has shown that once the canopy is considerably broken the danger of windfall is great. The soil is deep and moist, and trees upturn easily.

Until the last few years the prevailing system has been to cut all merchantable material, leaving a few old defective Douglas firs as seed trees, and then broadcast burn the area. One of the problems of the system has been to burn the area successfully and yet keep the fire under control. The operable portion of the stand does not usually extend more than half way up the side slopes, and it is a very hazardous operation to dispose of the slash successfully on the cut-over bottoms and slopes. The upper slope timber can be operated at some future date and is also a big factor in supplying seed for reforesting the cut-over area. A recent departure from the earlier system has been to break up the slash into blocks by leaving wide belts of green timber across the main drainages and so keep the slash fire from getting too much of a head; these strips also act as an additional source of seed. If the slash can be properly disposed of and subsequent fires do not occur, satisfactory reproduction is obtained.

A still more recent system of operation proposed for this type is selective logging. There are, no doubt, certain types of management which will admirably fit into such a scheme, as for instance where pulpwood is the desired product. There are also certain types of Douglas fir stands operated for saw timber to which it can be applied. The scheme is to make a large number of light cuts and so not disturb the canopy too abruptly. Whether it can be applied generally to Douglas fir stands is yet to be determined, but it is questionable if it can be without depreciating the quality of the forest. The advent of the tractor and truck has made the application of such a system more feasible, with its proposed frequent returns to the same area.

Engelmann Spruce Type. Although there are strong indications that Engelmann spruce may become of outstanding importance in the future for pulpwood, to date it has largely been the source of supply for portable sawmill operations cutting to meet local demands. The type usually contains 70 to $80 \%$ of Engelmann spruce, the balance of the stand being made up of alpine fir or cork bark fir or both. The type often merges with the lodgepole pine, of which it may contain considerable quantities along its margins. The character of the stand varies with site and aspect. In the middle and southern portions of its occurrence it can usually be successfully operated on a selection system of cutting, quite a range of age classes being present in the stand. From 30 to $50 \%$ of the volume is reserved. The slash 
is lopped and scattered, except along main roads and adjacent to camps where it is piled and burned.

In the northern portion of its occurrence the stands are more inclined to be pure and even-aged, particularly on north and east slopes. Here some method of clear cutting, leaving strips or blocks, is advocated, since experience has shown that the long-boled, short-crowned, reserved trees are broken off or overturned by sleet and wind storms. In the reserved portions of the stand no cutting of any nature is made, the object being to leave the stand intact. Usually about $25 \%$ of the volume is left. The slash is piled and burned.

Lodgepole Pine Type. This type often occurs as a pure stand of lodgepole pine, although scattered individuals of Engelmann spruce and alpine fir are commonly present. The younger stands lend themselves to a selection system of cutting. Lodgepole pine where reasonably accessible is in demand for ties and telephone poles, so a selection system permits harvesting these products as they reach merchantable size. The trees marked for cutting usually have a diameter of 12 inches d.b.h. or larger, although in some instances 12- or 13-inch trees are reserved for further growth when they will not cut two ties.

By far the greater portion of the lodgepole pine stands in the National Forests, however, are over-mature, and the differences in age between the trees of different diameter is negligible. There is much material which is below merchantable size for anything except mine props and lagging, and the market for these products is very limited. As a result the selective system of cutting is generally followed in these old stands also, not through choice but because it is the only method which can be economically justified. In the few instances where there is a market for mine props and lagging, clear cutting is resorted to, and this is considered the proper silviculture for the overmature lodgepole pine stands. In selective cutting, many suppressed pines of small diameter are left which give little promise of ever developing into merchantable trees. On the other hand, there are always some co-dominant trees just under merchantable size which will be stimulated after the cutting and develop into merchantable size. Therefore, though the system followed is not ideal, the results are better than if no cutting were done. If markets permitted, clear cutting could be practiced largely in these old stands. Lodgepole pine is intolerant of shade, and a selection system of cutting cannot be followed indefinitely if the stand is to be regenerated; sooner or later clear cutting must be approached and a fresh start taken.

In the earlier National Forest cuttings, hewed ties only were taken, leaving a number of trees over hewing size. Of recent years, the 


\section{SILVICULTURE-METHODS OF NATURAL REPRODUCTION}

Forest Service has required that these large trees be taken as logs to be sawed into ties by small portable mills; this has resulted in much better silviculture. Usually, saw logs are taken from trees which are over 16 inches d.b.h. Where the trees over hewing size are scattered and do not constitute enough volume to justify a tie mill set, the operator is allowed to long-butt these trees and hew the balance of the stem into cross ties. 


\section{CHAPTER IX}

\section{SILVICULTURE-METHODS OF ARTIFICIAL REPRODUCTION (REFORESTATION OR TREE PLANTING)*}

\section{HISTORY AND DEVELOPMENT}

Tree planting is one of the most important aspects of forestry in the United States, especially in some sections. Reforestation has been actively carried on in Europe for many centuries, to supplement natural reproduction, as explained above, or independently of it.

The first tree planting in this country took place between 1740 and 1750 in Massachusetts, where oak was grown for ship timbers. Later, in 1819, pitch pine was used in the same state; and in 1820, chestnut, oak, hickory, and locust were seeded and planted on 40 acres in Rhode Island. Subsequently considerable planting was done, both of exotic species such as Norway spruce, European larch, and Scotch pine, and of domestic varieties such as white pine, oak, ash, maple, and others. The Timber Culture Act passed by Congress in 1873 gave a great forward impetus to tree planting in the treeless plains of the Middle West.

The first activity in reforestation by the states took place in New York, where extensive reforestation has been carried on. In 1929, the State Reforestation Commission of New York inaugurated a policy of spending $\$ 20,000,000$ to purchase and plant one million acres of idle and abandoned farmland. There are said to be more than a hundred million acres of potential forest land in need of planting in this country. Until 1905 the federal authorities made very few actual attempts to seed or plant in our National Forests.

In the latter part of the nineteenth century many railroads encouraged or actually engaged in tree planting to prevent snowdrifts and to grow fence posts and cross ties along their rights of way. At first, a few so-called ranger nurseries were established in our National Forests, but these generally proved to be failures. Reforestation by direct seeding or planting of trees was also attempted, but that gen-

* For enlarged description and explanation of this subject see "Seeding and Planting in the Practice of Silviculture," by Toumey and Korstian, John Wiley \& Sons, New York, second edition, 1931. 


\section{SILVICULTURE-METHODS OF ARTIFICIAL REPRODUCTION}

erally proved to be unsuccessful especially in our National Forests. The first real accomplishment was the planting of 9731 acres in the National Forests in 1914 at a cost of about $\$ 10$ per acre.

Since the World War, many states have established forest tree nurseries, and the planting program of the Forest Service has been accelerated by the installation of additional nurseries and active attempts to plant areas within the National Forest, especially in the Lake States. The Clarke-McNary Act of 1924 encouraged additional tree planting by the states from the subsidies granted by the government for the establishment of nurseries and the distribution of small

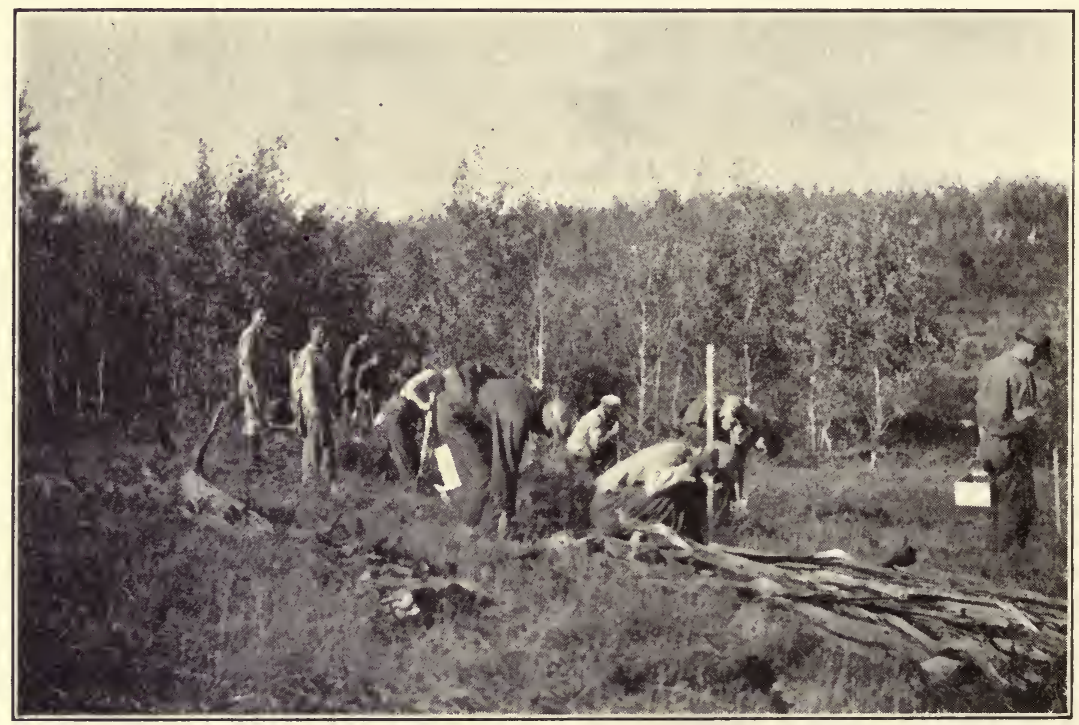

Fig. 55.-Planting crew at work in the Ottawa National Forest in Michigan.

trees. In a recent year, over 69,000 acres were planted in the National Forests; this represented the planting of approximately 70 million trees. The achievement was due largely to the availability of large numbers of men from the Civilian Conservation Corps and other government allotments of funds. Ten nurseries are maintained by the U. S. Forest Service, and three new ones.have been established at Manistee and Manistique, Michigan, having capacities of 25 millions and 18 millions of trees, respectively. One near Alexandria, Louisiana, has an annual production of 10 million trees. The Forest Service nurseries have an estimated annual production of 100 million trees, which will plant approximately 100,000 acres. There are about 2 million acres in need of planting in the National Forests. Planting 
is concentrated largely in the Lake States and in the southern pine region, the states, in order of importance in this activity, being: Michigan, Wisconsin, Idaho (largely from Savenac nursery), Wash-

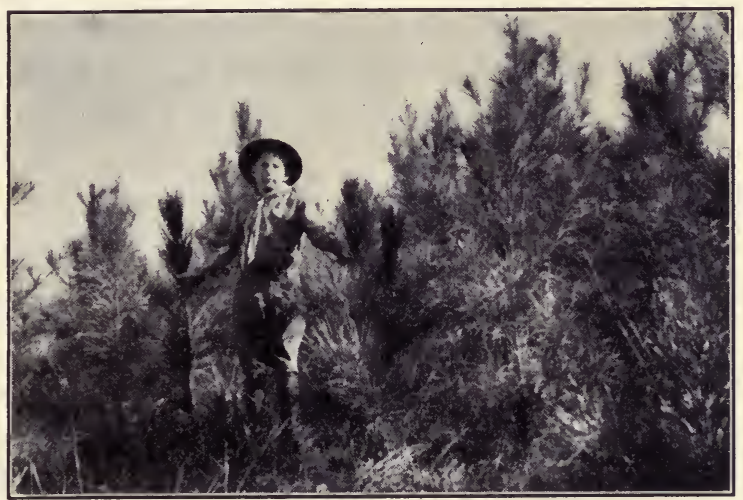

Fig. 56.-Slash pine planted on Boy Scout tract, Camp A 1 Siloh, Georgia. ington (from Wind River nursery), West Virginia, Colorado, and Montana.

In a recent year about 22 million trees grown and distributed by

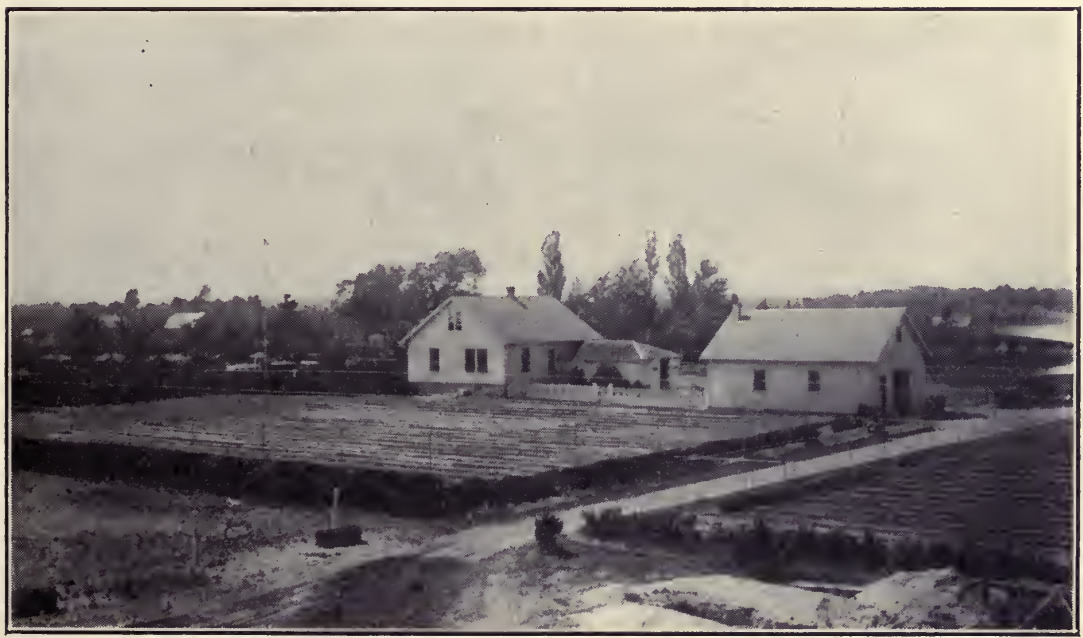

Fig. 57.-Beal Nursery, Huron National forest, Michigan, where large numbers of conifers are grown for planting in the Lake States.

states in cooperation with the Federal Government under the ClarkeMcNary law were planted in windbreaks, shelterbelts, and woodlots by farmers. 


\section{SILVICULTURE-METHODS OF ARTIFICIAL REPRODUCTION}

State nurseries contributed free of charge $11,820,000$ trees for planting by the Civilian Conservation Corps. Of these trees more than 2 million were planted on municipal forest areas, more than 8 million on State Forest lands, and a small number on private land. In addition to this, state nurseries, chiefly in Indiana, Kentucky, Ohio, Illinois, and Iowa, grew 40 million trees for erosion control planting, including a very large number of black locust.

\section{CONDITIONS REQUIRING TREE PLANTING}

Reforestation generally means restocking or the reforesting of land with forest trees. It is also known as tree planting, forest reproduction, or regeneration.

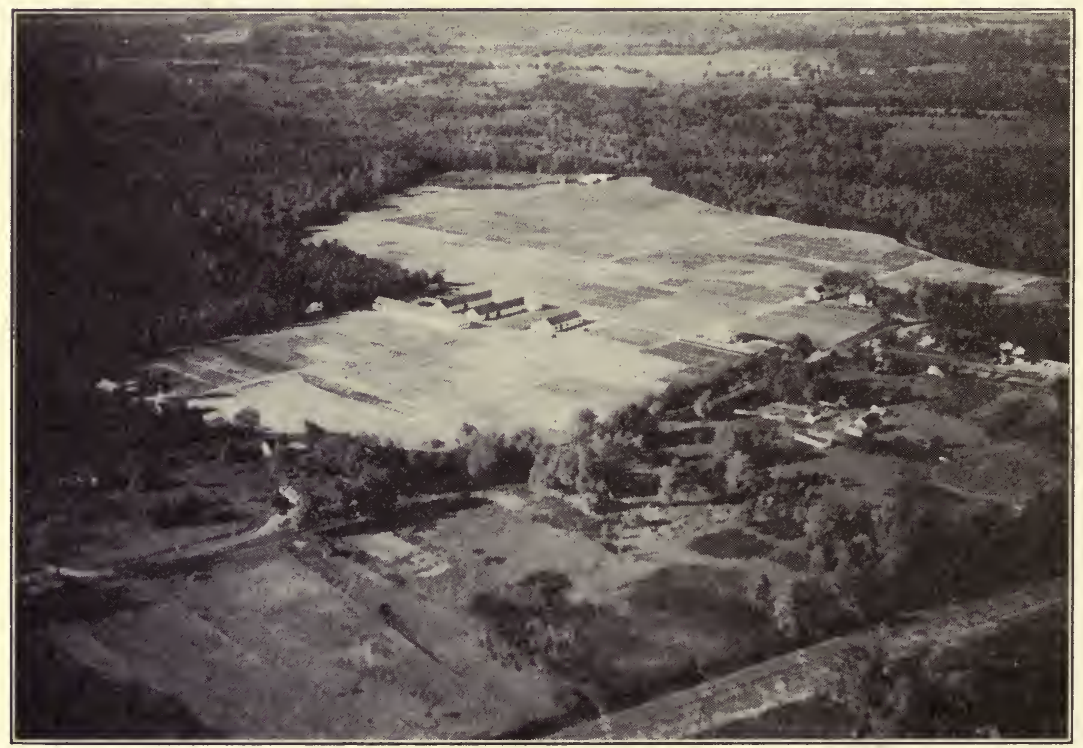

Fig. 58.-General aerial view of the Saratoga nursery in New York, one of the largest tree nurseries, which has a capacity of $50,000,000$ or more trees or an annual output of 20,000,000 3-year old transplants.

Artificial reproduction is accomplished by direct seeding, through broadcasting or strip or hand sowing, as well as by planting with wild or nursery-grown stock. Practically all reforestation is now being done by nursery-grown stock and is therefore referred to as tree planting. The conditions which require tree planting are generally as follows:

1. Submarginal agricultural land which generally has been aban- 
doned for use for farm crops. This is true of wide sections in New England and New York, where there are said to be 10 million and 5 million acres, respectively, available for tree planting. The same situation prevails in the South and the Lake States.

2. Burned forest areas that are not properly restocking to desirable species or a sufficient number of them.

3. Woodlots and farm woodlands partially stocked with native timber, but requiring additional planting.

4. Logged areas which are not sufficiently restocked with native growth, and which require partial or complete planting.

\section{SEED SELECTION}

In order to grow forest trees in nurseries, seed must be gathered. Enormous quantities of cones, acorns, and burs, are collected every year and seed is extracted from them in seed-extraction plants. As most of the planting is done with softwoods or conifers, the seeds of pines, spruces, firs, and larches are mostly in demand. For erosion control, black locust is being widely used in the Middle West, the South, and the Southeast.

The selection of seed from vigorous, healthy, well-formed specimens is of great importance. Attempts to grow Douglas fir from the lower altitudes of the West Coast in the cold climates of the Northeast and portions of Europe have been failures; seed to be used in those regions should have come from the Rocky Mountains or higher altitudes producing varieties of the same tree. Seed should if possible be collected from the locality where it is to be grown or at any rate from a place with a climate similar to that of the planting site.

\section{METHODS OF SEED COLLECTION}

Special crews are sent out in our National Forests, State Forests, and private forests to secure seed. The seed must be secured when it matures. In some tree species seed matures in one year; others require two years or more. Seed crops may vary from one to five or more years. Considerable technique has recently been developed in the procedure of seed collection; generally the following three methods of seed collection are used:

1. From the ground or water. Generally cones, burs, etc., may be gathered from the ground. Those of beech, elm, or maple often fall on water and may be collected when the wind has blown them into protected places. 
2. From standing or felled trees. With some species it is more economical to remove the cones from conifers before they have opened and scattered their seeds. Trees felled on logging operations at the proper season render seed collecting with some species very simple and inexpensive. Light-winged seed, such as those of elm, maple, and ash, may be collected from the ground rather than from standing trees.

3. From squirrel hoards or caches. This is a favorite method in many National Forests where squirrels gather large quantities of cones and other seeds for their winter supply.

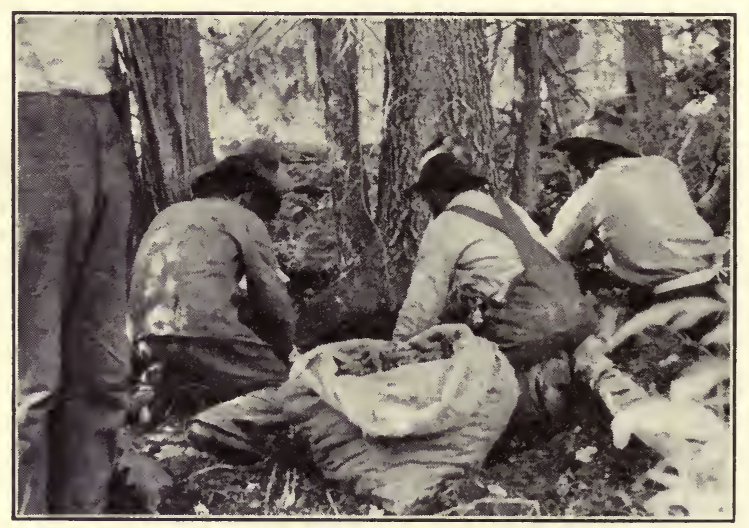

FIG. 59.-The first step in artificial reforestation is to secure tree seeds. Gathering cones from squirrel hoards. Four or five pounds of pine seed were obtained from this one hoard.

\section{NURSERY PRACTICE-SEED AND TRANSPLANT BEDS}

Reforestation is accomplished largely by planting tree seeds in nurseries and developing them for one to four years until they have reached sufficient size and have adequate root development to plant them in their final location. Forest tree nurseries are generally divided into seedbeds and transplant beds. Seed beds are rectangular plots $4^{\prime} \times 6^{\prime}, 4^{\prime} \times 12^{\prime}$ etc., where the trees are left to grow for one or two years. Transplant beds consist of rows in which trees taken from the seedbeds are placed generally an inch or more apart, and left to develop for another year or two. Trees are seldom used for transplanting when over four years of age.

Great care must be used in the selection of the nursery site. The most important factors to be considered are:

1. Favorable soil with proper drainage facilities. A light, sandy 
loam is preferred, and it should be deep and fresh. It should be capable of easy drainage.

2. An abundant and inexpensive water supply by means of piping. Generally, nurseries need to be irrigated during the warm summer season, and an extensive system of underground and overhead piping is often required.

3. The slope and aspect must be favorable. A gentle slope is preferred, and northern aspects are desirable.

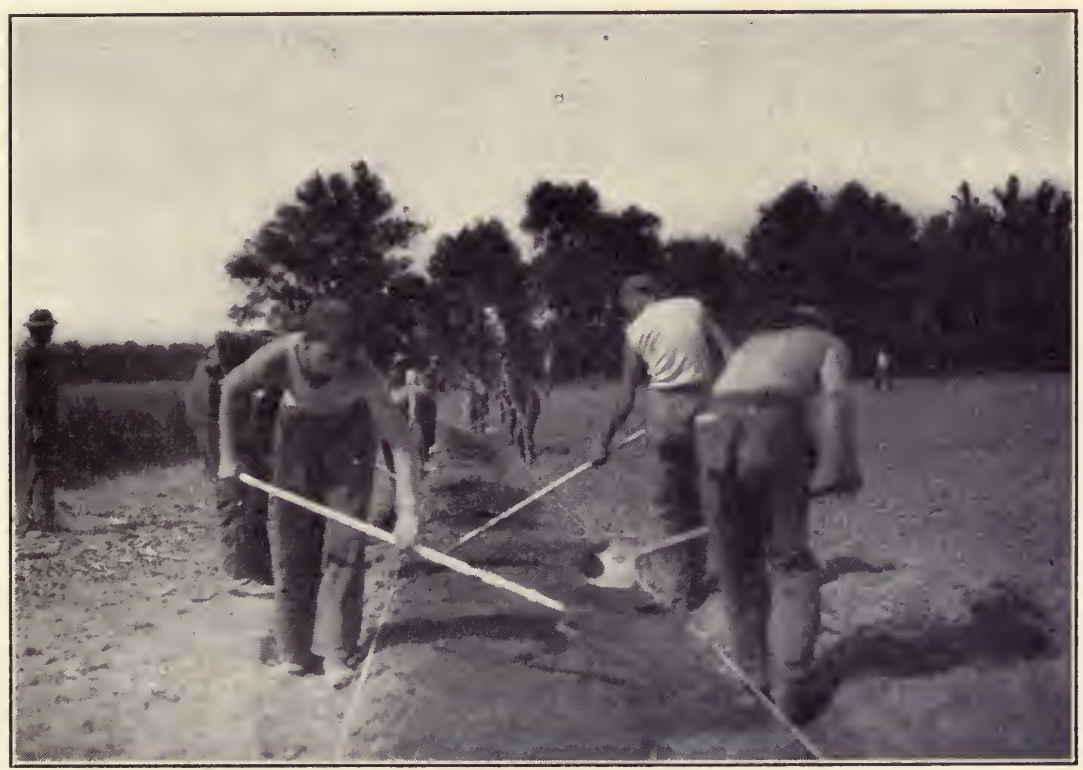

FIg. 60,-Preparing seed beds for 2,500,000 black locust seedlings near Ware, Illinois. Many of the trees produced are used in gully control in erosion work.

4. Tree species to be developed. Trees are very particular as to their soil, moisture, site, and aspect requirements, and these must be carefully studied in relation to the nature and location of the nursery.

5. Adequate and inexpensive labor. Trained labor is seldom available. After a few years of training the laborer is much more efficient and helpful.

6. Proximity to planting site. This is not enuirely necessary, as little trees may be transported considerable distances, but a nursery located under the same altitude and climatic conditions will produce trees that will thrive better when planted.

Trees used in planting are generally identified for the number of years left in seed beds and in transplant rows, as follows: 
1-0 One year in seed bed only.

2-1 Two years in seed beds and one year in transplant rows.

2-2 Two years in seed beds and two years in transplant rows.

Larger plants than four years of age are generally considered too expensive for use in forest planting.

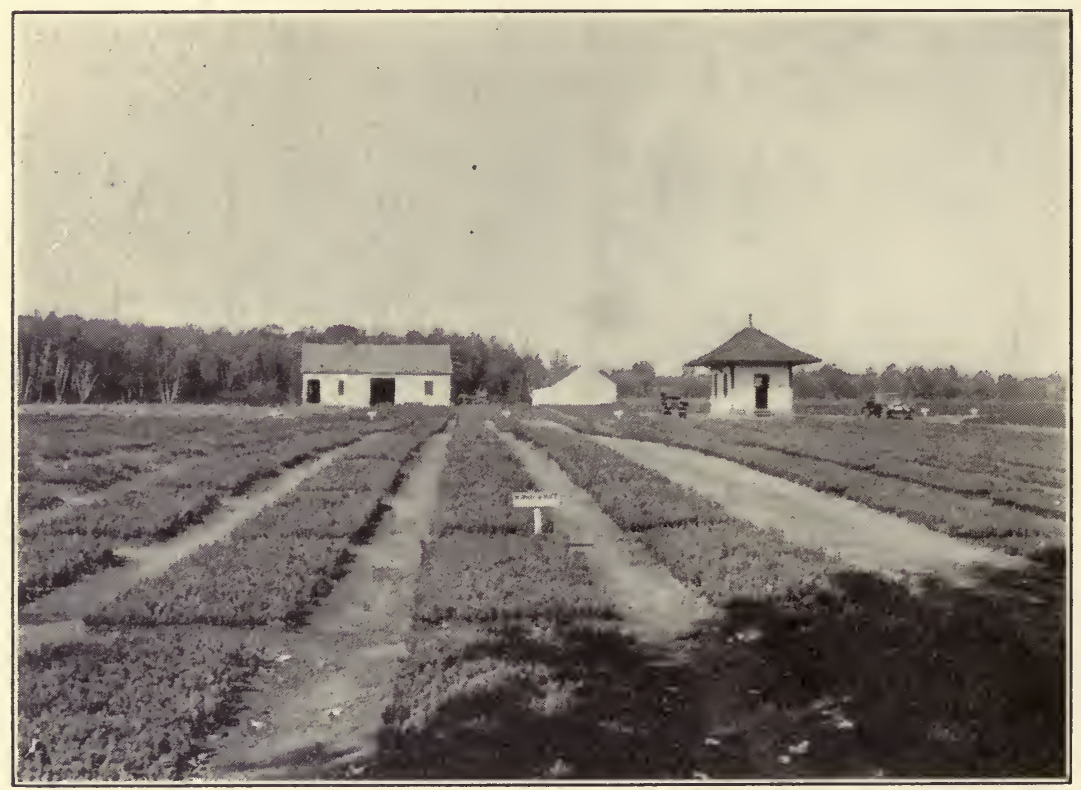

Fig. 61.-2-year old seedlings of Norway spruce in seedbeds at the Saratoga nursery, New York.

\section{WHEN TO PLANT}

Planting is generally done when trees are from one to four years old. At that time they are easy to transplant, easy to lift from the soil, and relatively easy and cheap to plant; the likelihood of survival is high, and the trees are of sufficient size to compete with the grasses and weeds which are usually found on planting sites.

It is of importance to use larger and more resistant planting stock wherever the difficulties, such as competition, are severe.

Planting is usually done during the spring in the North and Northeast and Northwest as soon as the frost leaves the ground. In the South, planting may be done any time throughout the dormant season, that is, during the winter. Autumn planting is sometimes practiced in the Lake States and Northeast but is not generally recommended in regions and on sites where frost heaving may be severe. 


\section{HOW AND WHAT TO PLANT}

The tool most commonly used for planting is the grub hoe or mattock. The sod may be removed and a hole of a convenient size for the plants may be made. This method is known as hole planting.

Slit planting is done by making a slit with a mattock or spade in which the roots are placed and the slit is pressed together.

It is of importance, in both methods, that the roots be well distributed in the soil and that the plant be placed neither too deep nor

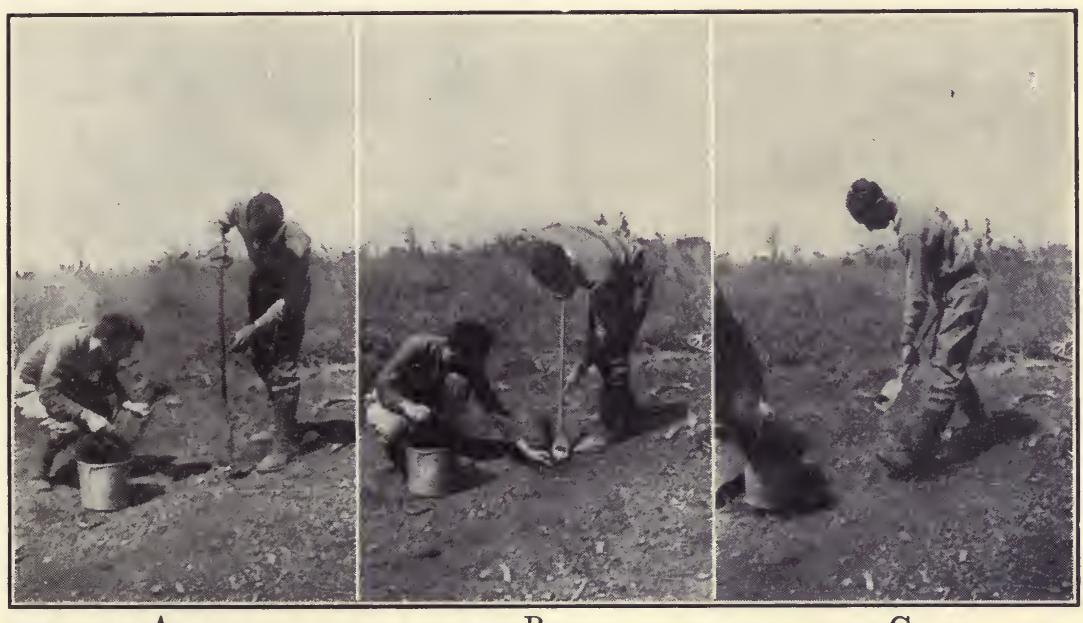

A.

B.

C.

FIG. 62.-Planting-bar or dibble method of planting forest trees as used in the South. A. Making the hole. B. Inserting the seedling and closing bottom of hole with second stroke of planting-bar. C. Closing top of hole with heel. Near Bogalusa, Louisiana.

too high in the soil, but at a height which compares with its natural position in the nursery bed. The soil must always be firmed compactly about the roots, generally by the pressure of the planter's foot.

The planter may use the mattock and plant the tree himself, or one man may make the hole with the planting tool and another man may carry the plants and do the planting. Two men generally work in one crew.

From 300 to 800 trees may be a day's work of 8 hours for one man, depending upon sizes of plants, and the character of the planting site. Thus a two-man crew may plant from 600 to 1600 trees per day.

On sandy soils, when planting is easy and weed competition is usually of little significance, small plants often one or two years old may be successfully used. The planting tool commonly used under 
these conditions, notably in the South, is a dibble or planting bar. By such methods, two or three times as many trees may be planted per man per day as with the mattock.

Recently the Syracuse forestry plow as developed by Heiberg has been successfully used in the East where the planting site, usually submarginal land, is free of large rocks, logs, or stumps. The plow clears and cultivates a strip in which planting and direct seeding are

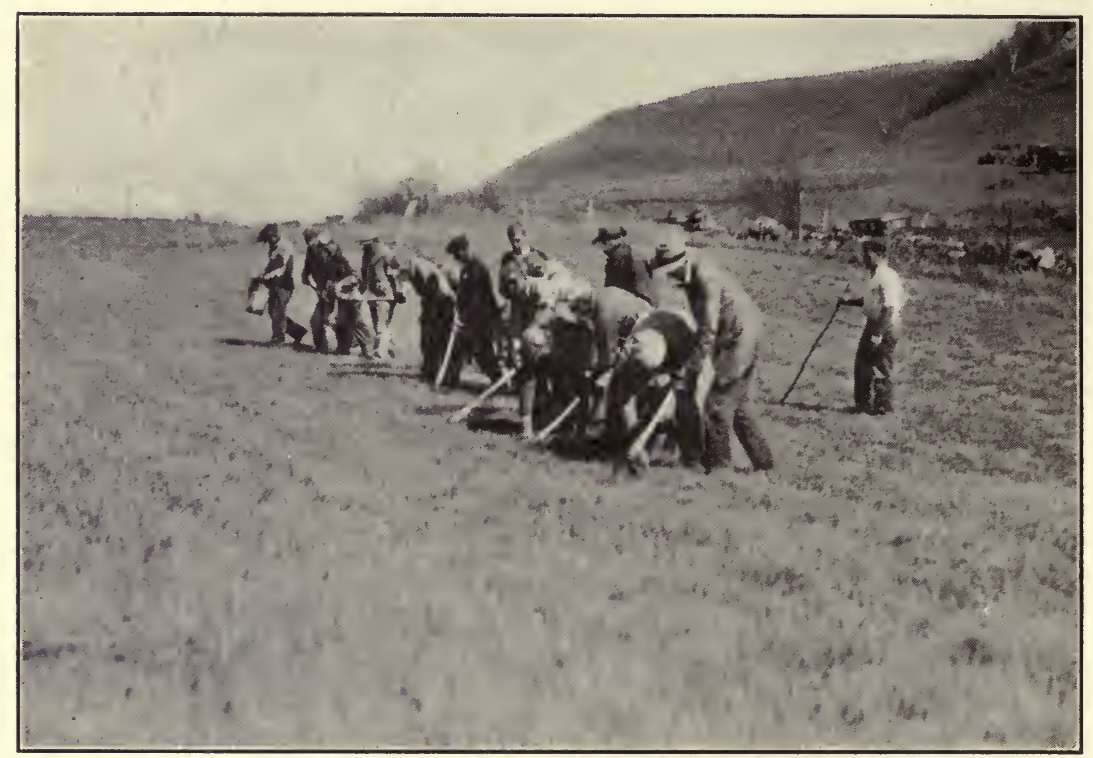

Fig. 63.-A series of seven, two-man planting crews reforesting submarginal land under the direction of a planting foreman. One man makes the hole with a mattock, and the other plants the little tree. Under favorable conditions, such as shown in this picture, 2 men can readily plant from 1000 to 1200 trees or more per crew in an 8-hour day.

extremely simple and easy, weed competition is reduced, and moisture conditions are more favorable. The cost of planting an acre including plants and planting is usually from $\$ 5$ to $\$ 10$ per acre, and somewhat lower when the plow method is used.

The following table illustrates recommended spacing for forest trees used in general field planting as well as in gullies and eroded areas. These species are largely used in the South, the Southeast, and the lower Central States, depending upon climatic and other local conditions. Some, as longleaf pine, are used only in the warmest portions of the South. 


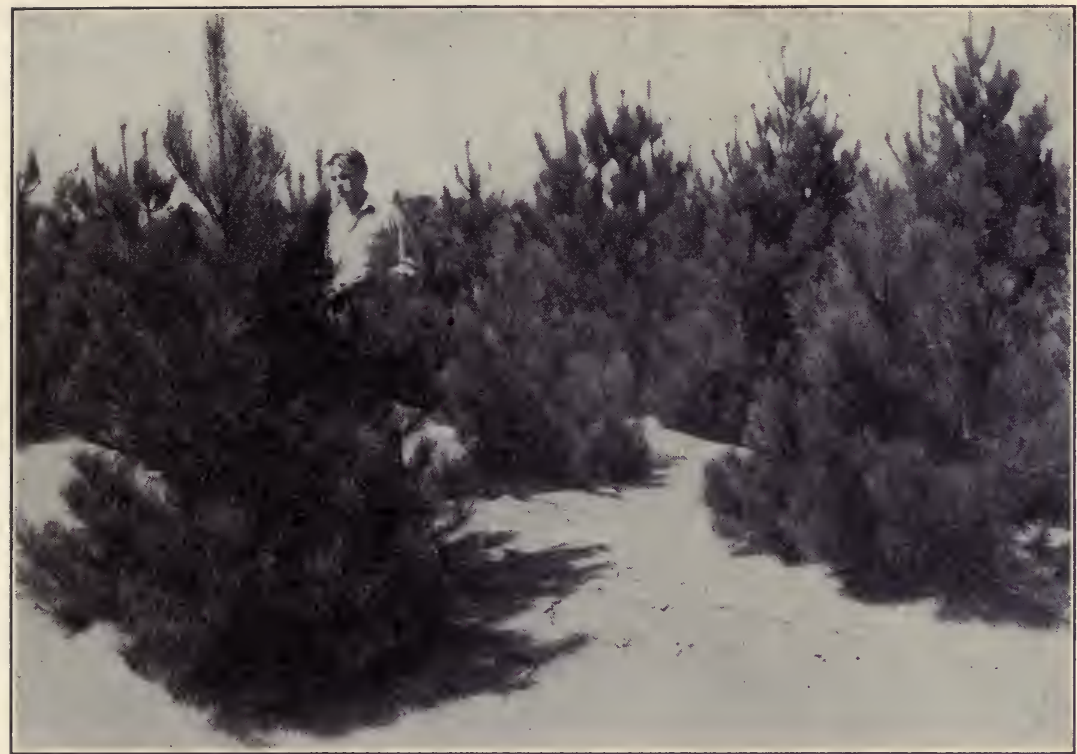

Fig. 64.-Red pine used for fixation of moving sand dunes. These trees thrived on practically pure sand on an inland dune. Photo by S. O. Heiberg.

Spacing For Some Forest TreEs

\begin{tabular}{lcc}
\hline \multicolumn{1}{c}{ Species } & $\begin{array}{c}\text { Spacing For } \\
\text { Field Planting }\end{array}$ & $\begin{array}{c}\text { Spacing in Gullies and } \\
\text { Heavily Eroded Spots }{ }^{1}\end{array}$ \\
\hline Loblolly pine & Feet & Feet \\
Shortleaf pine & $6 \times 6$ & $4 \times 6$ or $4 \times 4$ \\
Longleaf pine & $6 \times 6$ & $4 \times 6$ or $4 \times 4$ \\
Cedar, eastern red & $6 \times 6$ & $4 \times 6$ or $4 \times 4$ \\
Black locust & $6 \times 6$ & $4 \times 6$ or $4 \times 4$ \\
Willows & $6 \times 6$ or $5 \times 6$ & $4 \times 6,4 \times 4,5 \times 6$ \\
Cottonwoods & $\ldots \ldots{ }^{3}$ & $2 \times 4,4 \times 4$ \\
Tulip poplar & $\ldots \ldots 3^{3}$ & $2 \times 4,4 \times 4$ \\
Black walnut & $8 \times 8$ & $6 \times 8,8 \times 8$ \\
Oaks ${ }^{2}$ & $8 \times 8$ & $6 \times 8,8 \times 8$ \\
Catalpa & $3 \times 3$ & $3 \times 3,4 \times 6,3 \times 6$ \\
Sycamore & $7 \times 7$ & $\ldots . .3$ \\
Green ash & $8 \times 8$ & $4 \times 6,6 \times 8$ \\
White ash & $6 \times 6$ & $4 \times 6$ \\
\end{tabular}

1 Interplanting and stagger arrangement usually changes the planting ratio.

2 Oaks are best planted by direct seeding.

3 Not generally used for this purpose. 
Spacing for trees in general planting as used in the Lake States and Northeast is as follows:

\section{SPECIES}

White pine $\ldots . \ldots \ldots \ldots \ldots$.

White spruce $\ldots . \ldots \ldots \ldots \ldots$.

Norway spruce $\ldots \ldots \ldots \ldots \ldots$

Norway or red pine $\ldots \ldots \ldots \ldots$

European larch $\ldots . \ldots . \ldots . .$.

Scotch pine $\ldots . . . \ldots \ldots \ldots$

Spacing (Feet)
$4 \times 6$ or $6 \times 6$
$6 \times 6$
$6 \times 6$
$6 \times 6$ or $8 \times 8$
$6 \times 6$ or $8 \times 8$
$6 \times 6$

Ponderosa pine is generally spaced 8 by 8 feet in the West; Douglas fir, 8 by 8 or 6 by 6 feet; and western white pine, 6 by 6 and 8 by 8 feet.

The number of plants per acre for some typical spacing is as follows:

\begin{tabular}{|c|c|c|}
\hline SPACING IN & NumbF & F TrEe \\
\hline $4 \times 4$ & & 2722 \\
\hline $5 \times 5$ & ... & 1742 \\
\hline $6 \times 6$ & $\ldots \ldots \ldots \ldots \ldots \ldots$ & 1210 \\
\hline $8 \times 8$ & $\ldots \ldots \ldots \ldots \ldots$ & 680 \\
\hline $10 \times 10$ & $\ldots \ldots \ldots \ldots \ldots$ & 435 \\
\hline
\end{tabular}

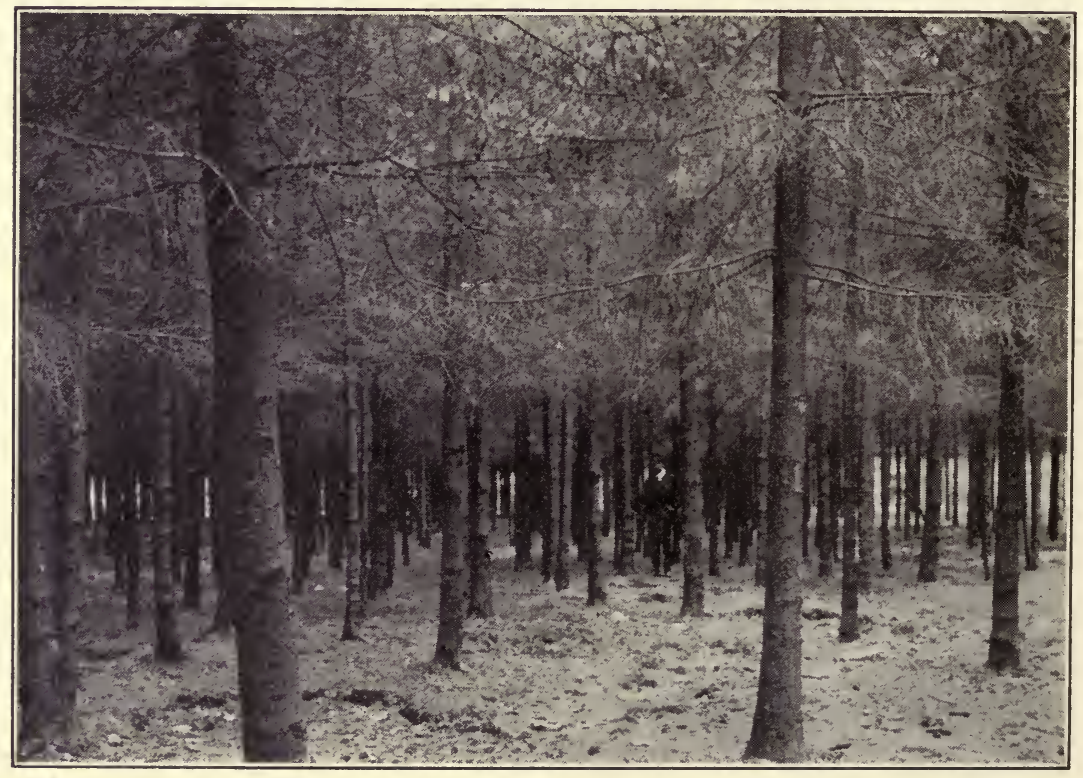

Fig. 65.-An interior view of a 24-year old Norway spruce plantation. These trees are nearly large enough to supply pulpwood, worth $\$ 3$ to $\$ 5.00$ per cord, on the stump. The lower branches have been pruned to produce clean boles and to eliminate knots. This forest is in need of thinning. 


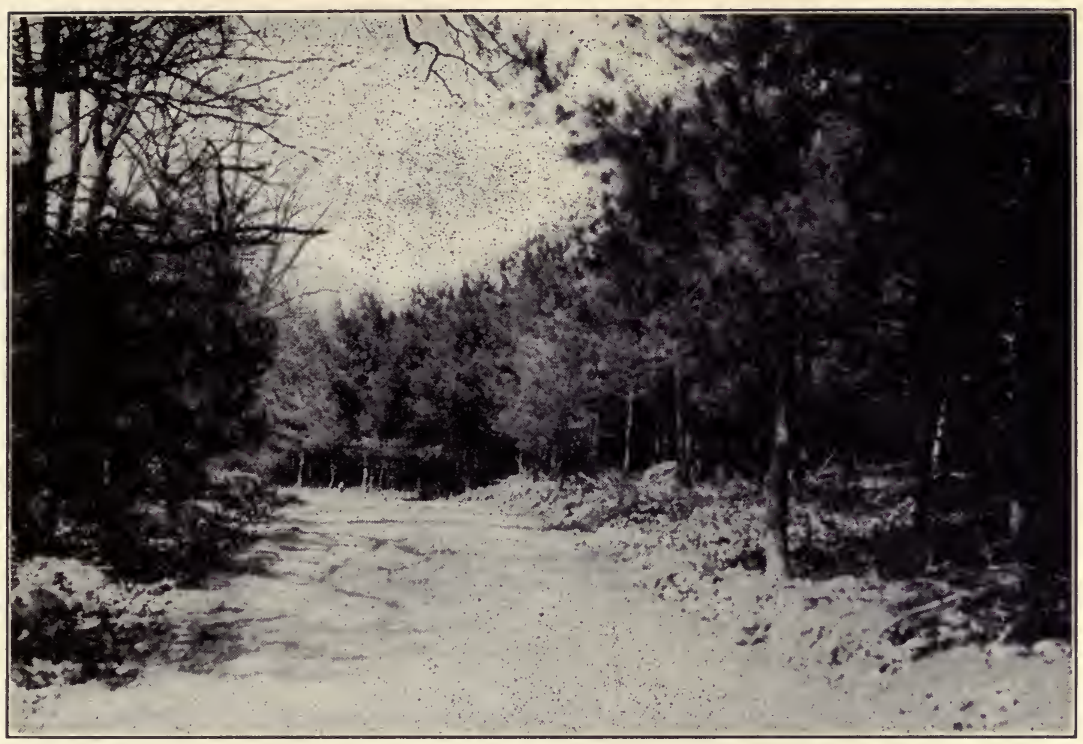

FIG. 66.-A 15-year old plantation of white pine in the 600 acre woods on the President's farm at Hyde Park, New York. These woods have been carefully managed to produce sawlogs, piling, posts, and fuelwood. Over 150,000 trees, chiefly white pine, red pine, Norway and white spruce, European larch, and yellow poplar have been planted on this place during the past several years.

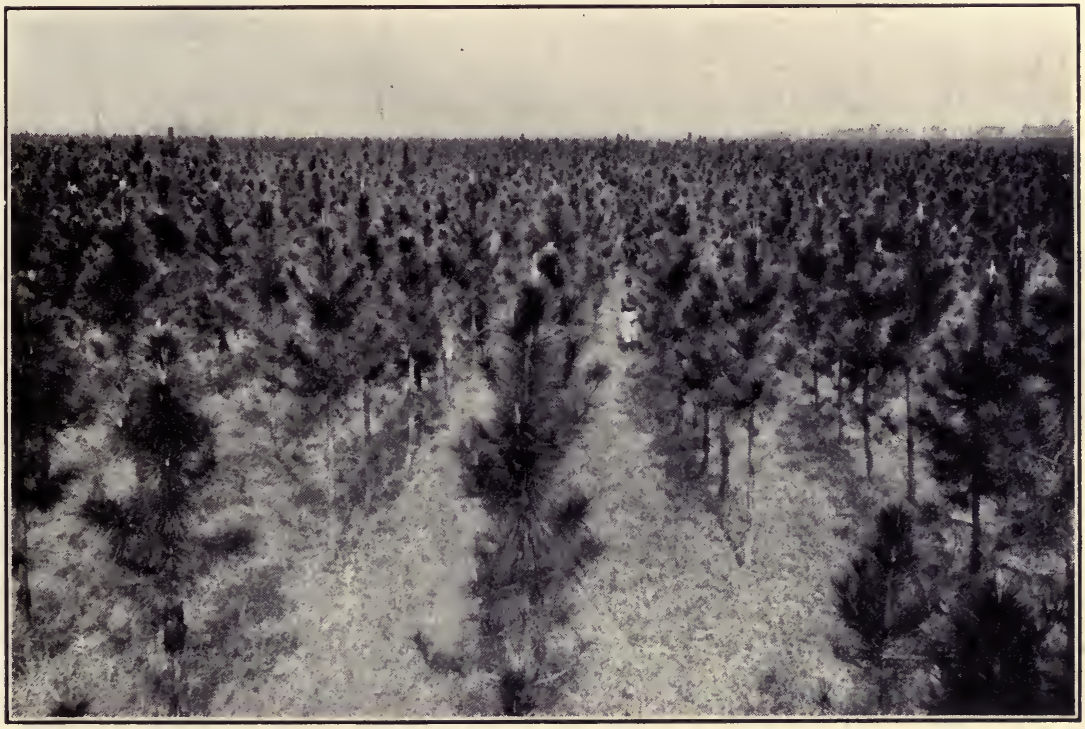

Fig. 67.-Planted slash pine 7 years old from seed. Spacing 6' $\times 8^{\prime}$. Peter's Creek plantation, Washington Parish, Louisiana. 


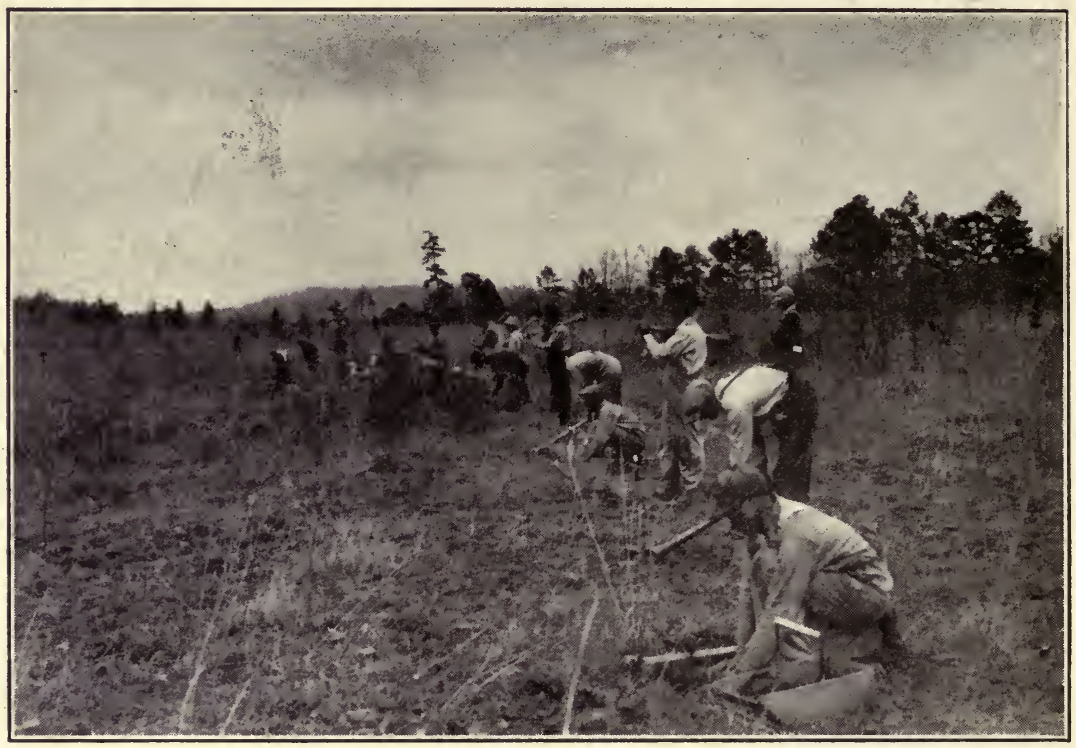

Fig. 68.-A planting crew at work. Ozark National Forest, Arkansas.

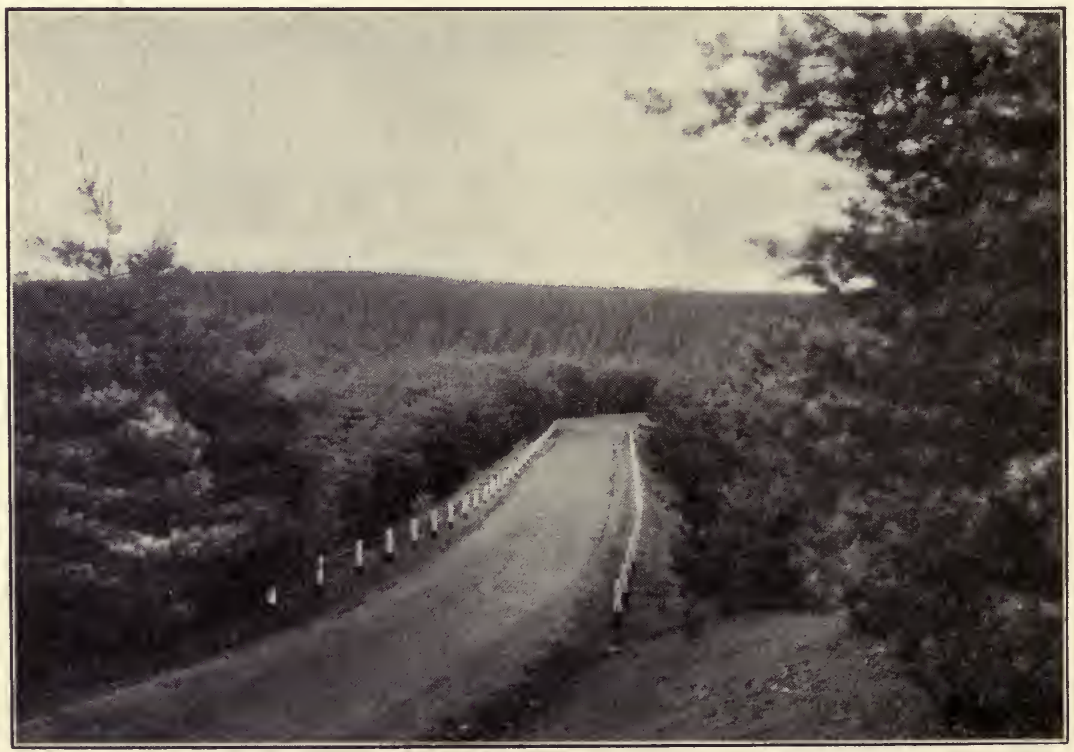

FIg. 69.-Plantation of white pines along roadway, York County, Pennsylvania 


\section{USE OF WILD STOCK IN PLANTING}

Except for individual trees for home ground, park, or street planting, the use of seedlings and trees growing naturally in the woods or open fields is generally unsatisfactory. The expense involved to obtain large numbers of little trees for reforestation purposes is generally not justified. Trees can be grown on a large scale in the nursery much more cheaply than trees can be dug up from their natural conditions. Furthermore, wild seedlings frequently have a scattered and tender root system and generally a deformed crown or leaf arrangement. Seedlings grown in nurseries generally have compact roots and crowns, and they are better equipped to withstand the change in transplanting from the nursery to the planting site. The cost of digging wild stock is generally far greater than the purchase price of nursery-grown trees.

Individual trees from the fields and forests for planting purposes should be selected with great care; small ones should be chosen. Roots longer than 8 inches should be cut off, and trees with a fibrous and wide root system, especially in the upper 8 inches of soil, should be selected. Trees may be lifted with a shovel and moved to the new site, after the roots have been wrapped in wet sacks. 
CHAPTER X

\section{SILVICULTURAL TREATMENT OF YOUNG AND IMMATURE STANDS (INTERMEDIATE CUTTINGS)}

\section{GENERAL}

During the life of the stand, between the period of obtaining reproduction of forests and the time of logging (when the stand is re-

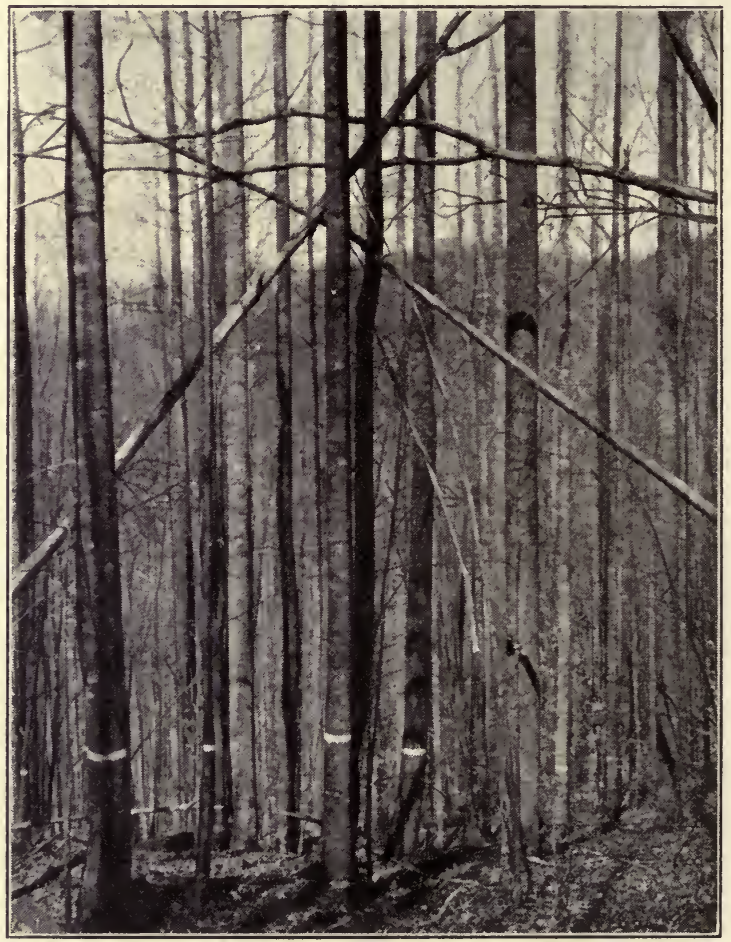

Fig. 70.-Thinnings in 40-year-old stand of dense second-growth yellow poplar. Trees to be left, after a selection thinning, are banded. Trees not banded are to be removed. First thinning removed 17 cords of $160 \mathrm{cu}$. feet each per acre and left 24 cords per acre as a residual stand. The larger trees cut in thinning are utilized for pulpwood. Cranberry, North Carolina. 
moved), cuttings are needed at various times to increase the rate of growth and to improve the quality, growing conditions, and composition of the forest. The forester attempts to correct the defects of nature, or rather to improve upon nature. All the cuttings made during the period of the rotation, that is, between reproduction and felling, are termed, according to Hawley, intermediate cuttings. In Europe these cuttings are made frequently and systematically through-

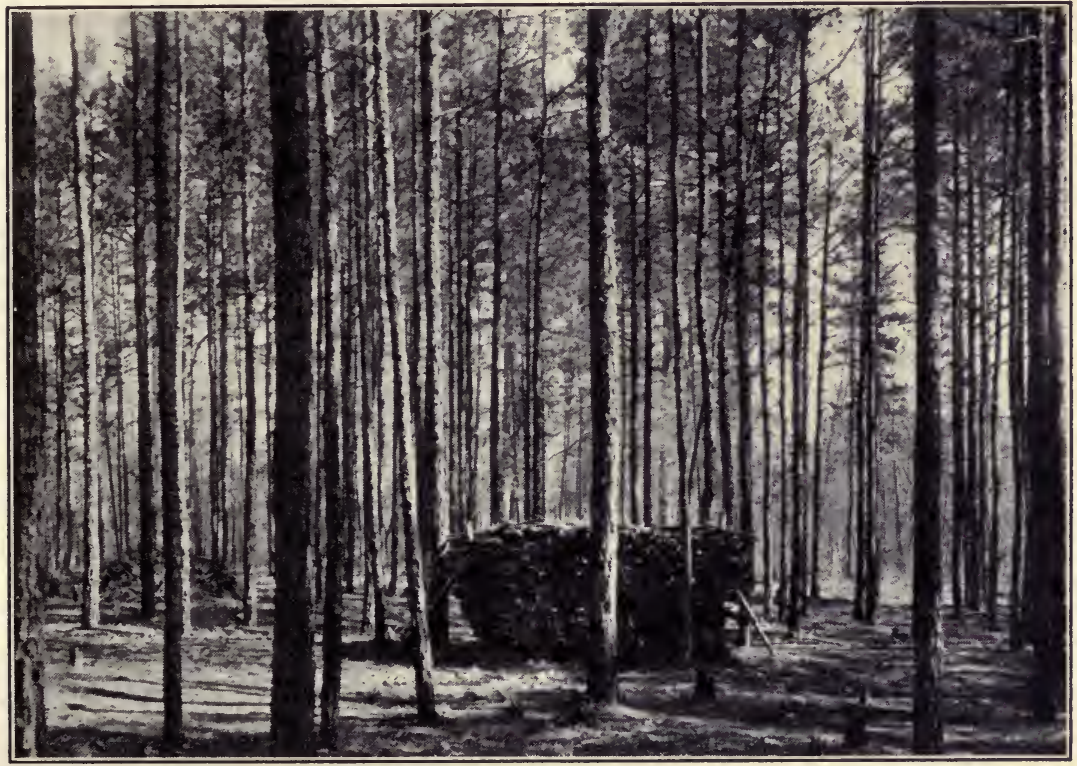

FIG. 71.-A stand of shortleaf pine, put into excellent condition for increased growth on one of the Soil Conservation Service projects in South Carolina. Such forests, on submarginal erosive lands, help hold soil in place. Photograph by Soil Conservation Service.

out the rotation period. They have proved to be very advantageous and profitable when economic conditions are favorable. Great skill is required in making these various forms of cuttings.

\section{ECONOMIC CONSIDERATIONS}

Only under a few conditions found in the United States are intermediate cuttings financially successful. This is because of unfavorable economic conditions and the relatively low prices obtained for forest products. Although many of these measures are relatively inexpensive and are within the capacities of well-trained and skilful 
foresters, they have generally been practiced only in some of our National and State Forests. In the demonstration forests of Harvard at Petersam, Massachusetts, and of Yale at New Haven, Connecticut, and Keene, New Hampshire; in the Duke Forest at Durham, North Carolina; as well as in the Pack demonstration forests located in connection with the University of Washington and the New York State College of Forestry, and several others, intermediate cuttings of this kind have been successfully made.

With the availability of vastly increased man power for work in the woods under the Civilian Conservation Corps program, a very large amount of work in intermediate cuttings and silvicultural treatment of young and immature stands has been accomplished, notably in the National and State Forests of the Lake States, southern Appalachians, southern pine region, and the Northeast. Considerable work has also been done in ponderosa pine and lodgepole pine stands of the Rocky Mountains, especially on National Forest properties.

\section{SILVICULTURAL SYSTEMS OF TREATMENT}

The intermediate cuttings as classified and described by Hawley* are as follows. He recognizes six types of intermediate cuttings.

1. Cleaning. A cutting made in a young stand, not past the sapling stage, for the purpose of freeing the trees from other individuals of similar age but of undesirable form or species which are overtopping or are likely to overtop the former trees. The term "assistance cutting," "disengagement cutting," "release cutting," and "weeding" have been employed as synonymous. Of these synonyms, release cutting and weeding are considered the most desirable. An advantage claimed for these terms over the word "cleaning" is that they better express the purpose of the operation. As sometimes used, release cutting includes the operations under both cleanings and liberation cuttings and hence is less useful as a substitute for cleanings alone.

2. Liberation Cutting. A cutting made in a young stand not past the sapling stage, for the purpose of freeing the young growth from older individuals (wolf trees) which are overtopping. These older individuals may be either of good species but of the "wolf tree" character or else of species less desirable than the overtopped young growth.

* See "Practice of Silviculture," by R. C. Hawley, third edition; John Wiley \& Sons, New York, 1935. 
3. Thinning. A cutting made in an immature stand for the purpose of increasing the rate of growth of the trees that remain and the total production of the stand, and removing mostly trees not in a dominant position, in contrast to cleanings, liberation cuttings, and improvement cuttings, which characteristically take out only trees overtopping better individuals.

4. Improvement Cutting. A cutting made in a stand past the sapling stage for the purpose of improving the composition and character by removing trees of undesirable species, form, and condition, occupying dominant positions in the main crown canopy.

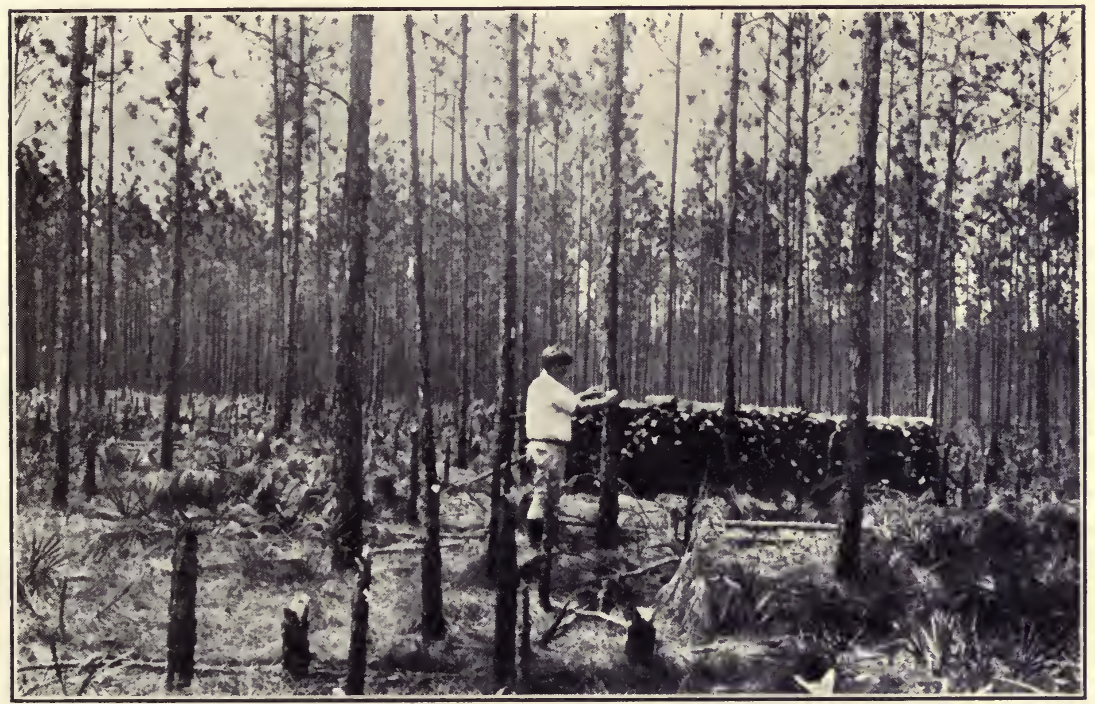

Fia. 72.-Thinned stand of longleaf pine in Columbia County, Florida. Age of stand is 25 years; 200 trees per acre were left in thinned stand.

5. Salvage Cutting. A cutting made for the purpose of removing trees killed or damaged by various injurious agencies, of which fungi, insects, and fire are the most serious.

6. Pruning. The removal of dead or living branches from standing trees for the purpose of increasing the quality of the final product by reducing the size and number of knots, or eliminating them in sawlogs used for lumber.

During the life of a stand there may or may not be need of applying all kinds of intermediate cuttings, but if applied they are likely to occur in the following order: 
Kind of Cutting

Cleaning ...........

Liberation cutting ...

Thinning $\ldots \ldots \ldots$

Improvement cutting

Salvage cutting .....

Pruning...$\ldots \ldots$

\section{Time of Application}

First to approximately the twentieth year

First to approximately the twentieth year

Early life to beginning of period of regeneration

Twentieth year to beginning of period of regeneration

Twentieth year to beginning of period of regeneration

First quarter or half of the rotation

\section{REMARKS}

Frequently unnecessary

Frequently unnecessary

Needed in all fully stocked stands

Usually required in mixed stands previously unmanaged

Used only in case of injury to the stand

Advisable only in special cases

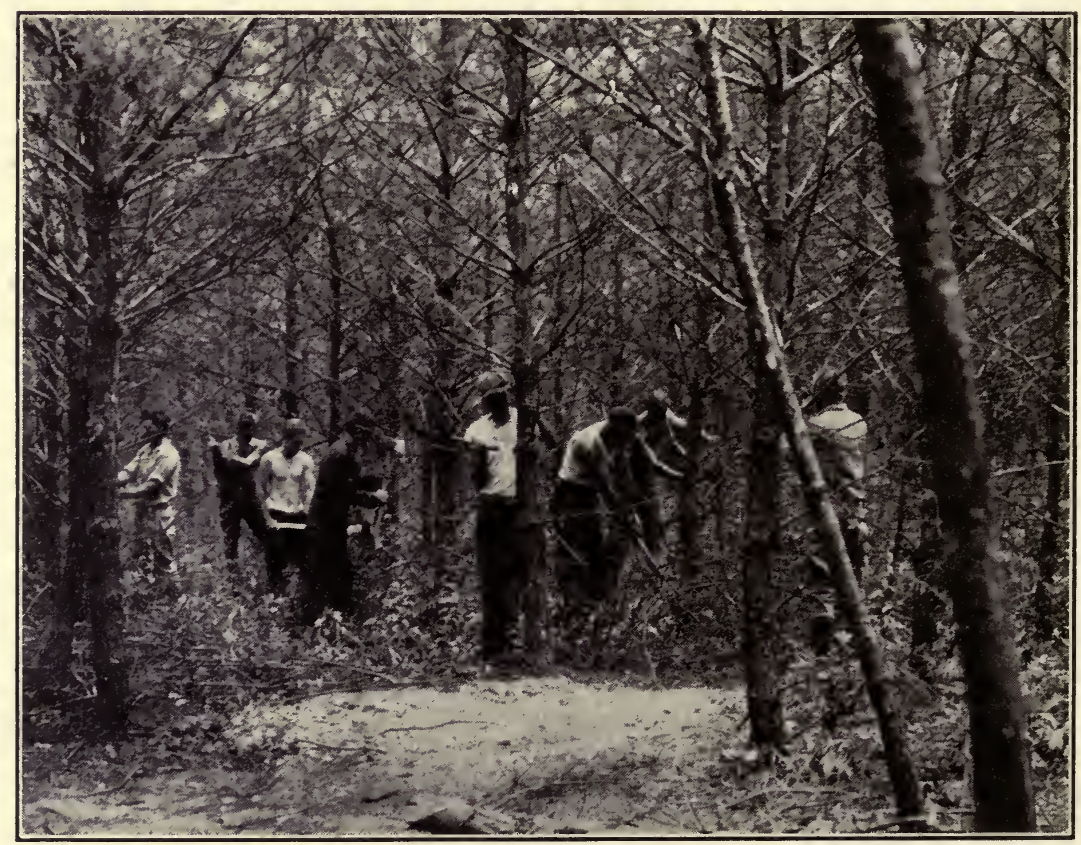

Fig. 73.-Thinning and pruning a stand of Scotch pine in Pennsylvania. The poorly formed, suppressed, weak, diseased and insect infested trees are removed and the crown space left for the better specimens. All dead or green branches up to a given height are cut off flush with the trunk to improve the quality of lumber produced from the trees when cut. Several million acres of Federal and State Forests have been thinned by the Civilian Conservation Corps in this way.

The most extensive thinnings have been conducted by the Civilian Conservation Corps, especially in the National Forests of the Lake 
States, the South, southern Appalachians, and the Northeast. Considerable work has also been done in State Forests. Girdling of hardwoods to free spruce and white pine has been done in the Northeast. In the pine and hardwood forests of the South, pine is often freed by thinnings and cuttings from old and inferior hardwoods. In Arkansas hardwoods, white oak is freed from inferior hardwoods as white oak stumpage is commanding prices up to $\$ 23$ per m.b.f. In Florida and elsewhere scrub oak is cut to free southern pine reproduction. Overcrowded lodgepole pine reproduction has been heavily thinned in Wyoming, Colorado, Idaho, and Montana. Liberation cuttings have been widely used in ponderosa pine in the West and throughout the hardwoods in the East on federal and state properties. In the Southwest, young stands of ponderosa pine are pruned to a height of about 17 feet.

\section{GENERAL RULES FOR THINNING*}

According to Heiberg, the following rules should be followed in making thinnings for the improvement of the growing conditions of any forest.

1. Mark the stand carefully before starting to cut. Do not make marking and cutting one job.

2. Mark all trees to be cut in such a way that the marks may be seen most easily by the loggers or cutters.

3. Aim in marking for the best development of the most promising trees rather than the removal of the poor trees.

4. Look up rather than down when marking. Remember that it is the size, shape, and spacing of the crowns which count rather than the spacing of the stems.

5. Do not mark trees if they cannot profitably be marketed or if no beneficial purpose is served by their removal.

6. Always mark "whips" but do not always mark "wolf trees." Removing them may sometimes cause more harm than good to the stand.

7. Thrifty stands are better objects for thinning than stagnating stands. A stand which has stagnated for several years is difficult, often impossible, to improve successfully by thinning.

8. Concentrate thinnings on areas to which one can easily return

* For further reading see "Measures for Stand Improvement in the Southern Appalachian Forests," 1933, and "Eastern Forest Tree Diseases in Relation to Stand Improvement," by G. H. Hepting, 1934, both published by Emergency Conservation Work, Washington, D. C.; also other government publications on the subject. 
for another cut. Frequent and light thinnings are far better than heavy thinnings with long intervals.

9. Do not let the best trees develop into "wolf trees"; keep sufficient "trainers" to prevent this.

10. Know the silvicultural and economic properties of the species and the quality of the site before starting to thin.

Some of the best opportunities for thinning exist in plantations that have crowded canopies, especially in stands of 15 to 40 years of age. 


\section{CHAPTER XI}

\section{FOREST UTILIZATION-INDUSTRIAL FORESTRY}

\section{GENERAL-IMPORTANCE OF THE LUMBER AND ASSOCIATED INDUSTRIES}

Forest utilization may be described as the profitable and efficient conversion of standing timber into forms useful in human economy and arts. It embraces the harvesting of forest crops, transportation of the raw material, chiefly logs to market, the manufacture into various usable commodities, and their merchandising and distribution to ultimate users. The main branches of forest utilization treat of:

a. Properties and uses of wood.

b. Logging.

c. Manufacture, conditioning, and treatment.

d. Merchandising and distribution.

Forest utilization constitutes the major part of the forestry operations practiced in our woods, on the basis of number of mer employed, capital invested, and influence on the future stands of timber. Forests are treated for better or worse when they are logged. European forestry has taught us that the best silvicultural tool is the axe. Logging may prove to be good or poor silviculture, depending upon the methods pursued. The lumberman should know more about forestry, and the forester should know more about the problems of logging as well as of lumber markets and the distribution of the products to their final use. In Europe the forester is generally the lumberman, and the lumberman is the forester. Both may have the same objects in view.

The market prices secured for forest produce are ordinarily the determining factor in the practice of forestry. Therefore, forest utilization may include some of the most important phases of American forestry. The large amount of waste attending American logging and lumber manufacture is chiefly due to relatively low prices secured for the final product.

The lumber and associated industries have for many generations served to furnish employment as well as shelter and structural materials for the up-building of the American nation. Utilization phases 
of forestry are therefore intimately related to the social and economic life of the country. That banking, transportation, the export and import trade, and general business are directly affected by the prosperity and general condition of the lumber and associated industries is shown as follows:

1. More than 10 billion dollars is invested in the forests and primary forest industries. Many additional billions are invested in industries depending upon the forest as a natural resource.

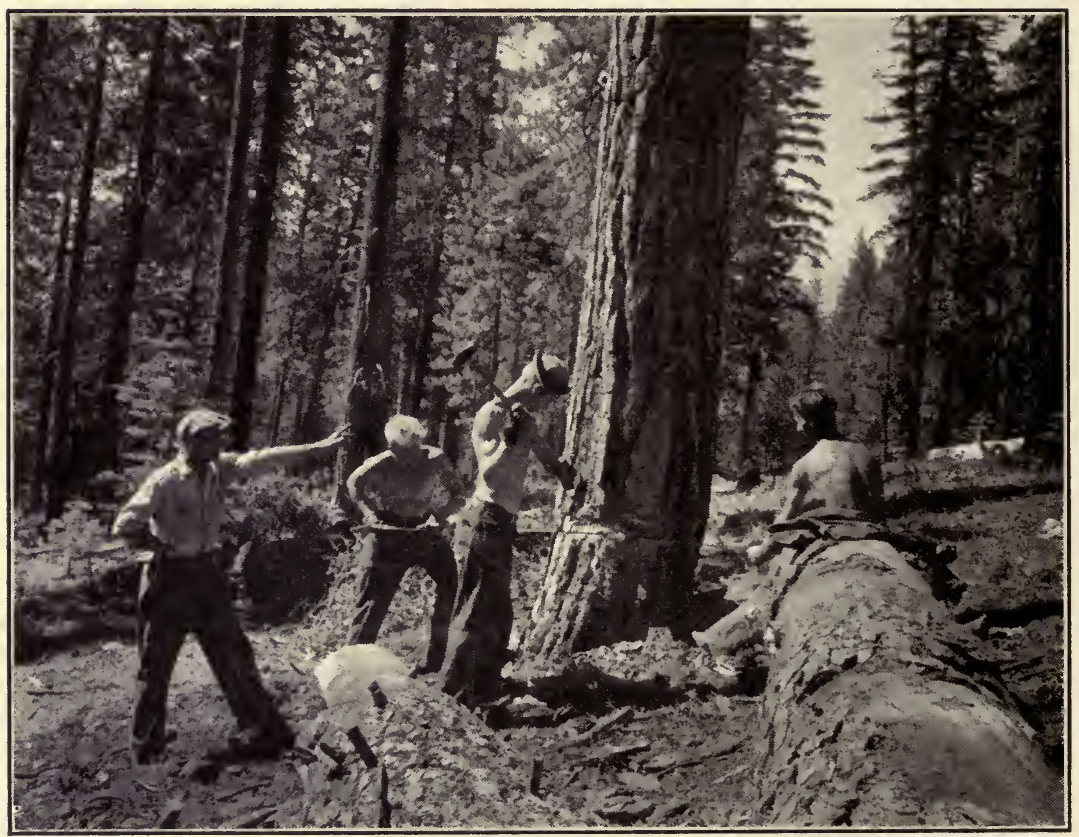

Fig. 74.-Forestry foreman teaching young men how to properly fall a tree in a ponderosa pine and white fir stand in California. A wedge is being inserted in back of the cross-cut saw. Stumps are cut low and the tree felled so that it will not injure young growing timber.

2. These industries furnish employment for over $1,300,000$ workers, or about $2 \frac{1}{2} \%$ of the gainfully employed persons in the United States, and an additional million men are indirectly supported through our forests and forest industries. Thus probably 8 to 10 million people or more are directly affected by these industries.

3 . The gross value of the primary products normally is about 2 billion dollars a year. Over 3600 million dollars is represented in total value of primary and fabricated products. 
4. Normally about 26,000 sawmills are engaged in the production of lumber, and the number of logging operations to supply these manufacturing enterprises is still larger. Pulp and paper, cooperage, cross tie, veneer, naval stores, and other industries depend upon the forests for their raw materials.

5. Imports of forest products including paper amounted to more than 400 million dollars in 1929 , or nearly $1 / 10$ of all our imports.

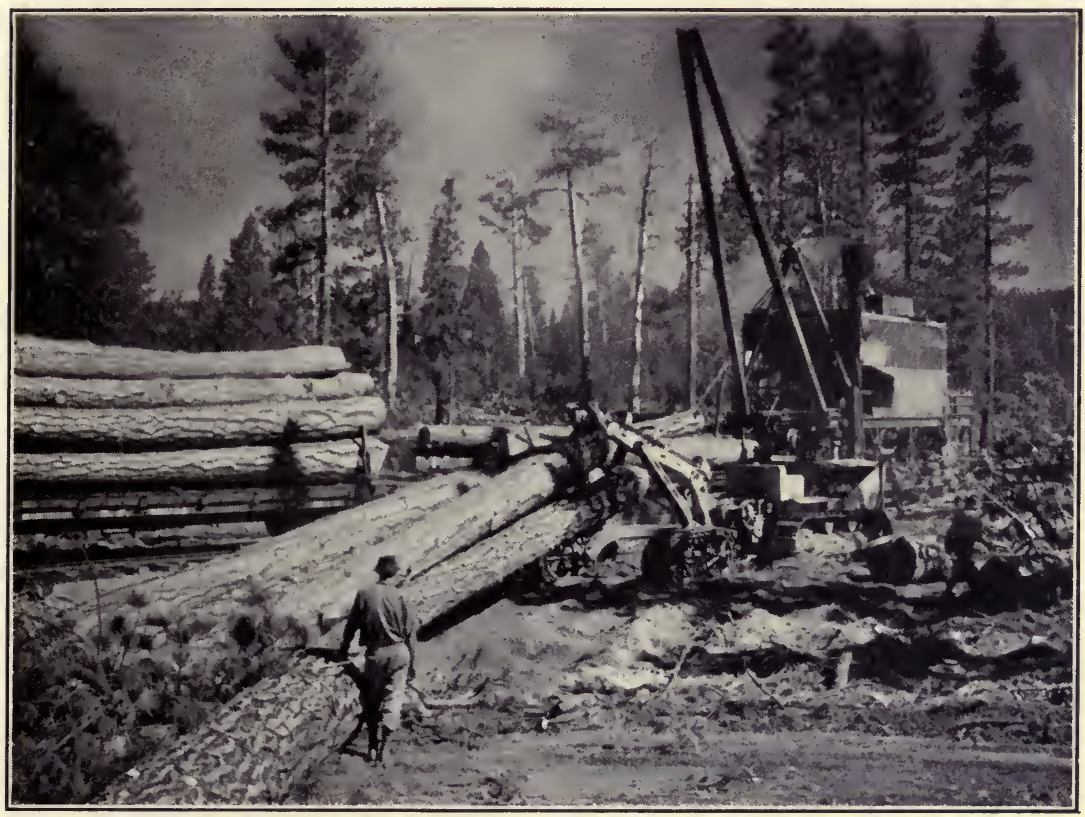

Fig. 75.-One of three Caterpillar Diesel tractors of 75 h.p. bringing in large size ponderosa pine logs in northern California with Hyster-Willamette arch mounted on Athey wheels. These machines burn about 21 gallons of Diesel fuel oil at $71 / 2 \mathrm{c}$ per gallon, as against 48 gallons of $15 \mathrm{c}$ gasoline per 8 hours with 60 h.p. gasoline units. The Diesel tractor has become widely used in recent years and is replacing gasoline tractors for log skidding.

The value of exports of forest products amounted to about 250 million dollars.

6. The annual transportation of forest products contributes about 170 million dollars normally to our railroad systems. Over $3,700,000$ carloads of forest products were shipped in one year on our railroads.

7. About 45 million dollars is spent annually for timber used to mine coal and other minerals. The lumber industry employs more than 3 billion primary horse power and is one of the four largest industries. 


\section{ADVANTAGES OF WOOD CONSTRUCTION}

Wood is the most economical and universally used construction material. It has many excellent qualities and is a commodity of such common use that its technical properties and advantages have only recently come to be properly understood and appreciated. Briefly summarized, the advantages of wood in the arts and industries, are as follows:

1. In proportion to its weight, wood is the strongest known material. Spruce is the strongest wood for its weight. Wood in general is stronger for its weight than steel.

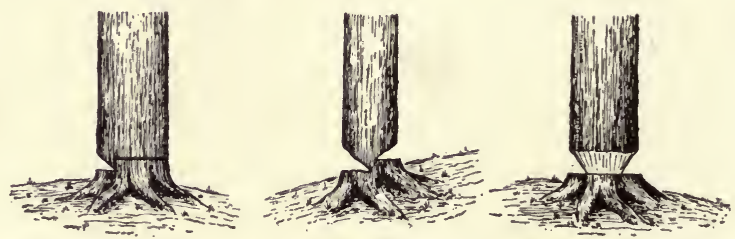

Fig. 76.-On the left is shown the usual type of under-cut or notch chopped by the axe with the saw cut made by the cross-cut saw. Some advorcate a slightly sloping cut made with the cross-cut saw. In the center is shown the method of felling by the axe. This is only used for the smallest trees and in pulpwood operations in the Northeast; also in making thinnings, swamping out roads, etc. On the right is shown a method of felling trees in Europe where low stumps are desired and felling of the small trees is done with the axe, the butt end of the log being "nosed" to facilitate skidding.

2. Wood is the most workable material available, and it lends itself readily to manufacture and re-manufacture into many shapes and designs. Most of our woods are relatively soft, and they may be shaped, reshaped, or combined in structures for many decorative as well as construction purposes.

3. Wood is a poor conductor of heat and therefore is excellent insulation material. Thus it helps to keep houses warm in winter and cool in summer. The wooden or frame home has many advantages in this respect over those of brick, stone, cement, concrete, or other materials.

4. The grain and appearance of wood are generally attractive, therefore they render it readily adaptable to artistic treatment. The beauty and attractiveness of furniture, paneling, interior finish, and trim make wood the best material for these purposes.

5. Wood is comparatively inexpensive; there is no likelihood of a national timber famine. There may be regional shortages, but wood 
is capable of being regrown, and probably it will always be available and relatively cheap on our markets.

6. Wood is abundantly available in many different sizes, shapes, and kinds for practically all forms of construction as well as many other purposes.

7. Wood is a natural product. It may be grown wherever mankind wishes, provided conditions favorable to tree growth are present. Metals, coal and oil are exhaustible resources. The forest, under proper management, may be handled to make it produce forever.

8. Wood is warm to the touch. This is why it is so much in demand for such purposes as automobile steering wheels, table tops, and chairs in preference to other materials.

9. Wood cleaves or splits. Though this may be a disadvantage, it is important in the preparation of firewood or fencing, rived shingles known as shakes, and for many other purposes.

\section{LOGGING METHODS AND PROCEDURE**}

Logging constitutes one of the oldest American industries. The wealth and extent of our forest resources have given employment for large numbers of people in the woods since earliest colonial days. For many generations, logging procedure followed substantially the established methods. Winter sled logging and stream driving were the practice during the early days of the industry in New England, New York, Pennsylvania, and the Lake States. In the South, mules and oxen were widely used in the pineries.

Logging continued as one of the great American industries and was centered for many years in Maine until 1840, then it shifted to New York, which

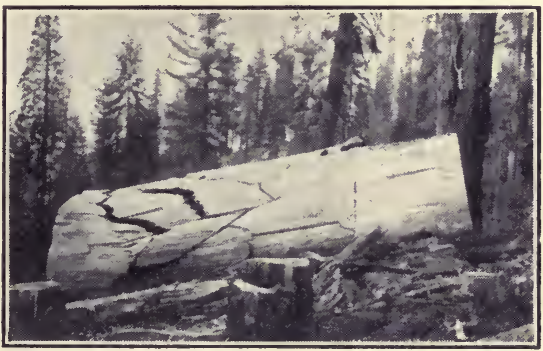

Fig. 77.-Many good logs are shattered in felling as shown above. This illustrates an extreme example of the amount of good wood lost in felling trees of large size and great weight. In felling the larger redwood trees, a bed made of limbs, brush, etc. is sometimes made to check the fall and prevent unnecessary breakage. became the leading lumber-producing state. Twenty per cent of the entire country's lumber supply was produced in the state, chiefly in

* For further reading, see "Logging-Principles and Practices," by Nelson C. Brown, John Wiley \& Sons, New York, 1934. 
the Adirondacks, and Albany was the great lumber market of the nation. In 1860 the industry became centered in Pennsylvania, and later Williamsport became a great lumber-manufacturing community. By 1870 , it had continued its nomadic and migratory career to the Lake States, where the magnificent virgin "cork" white

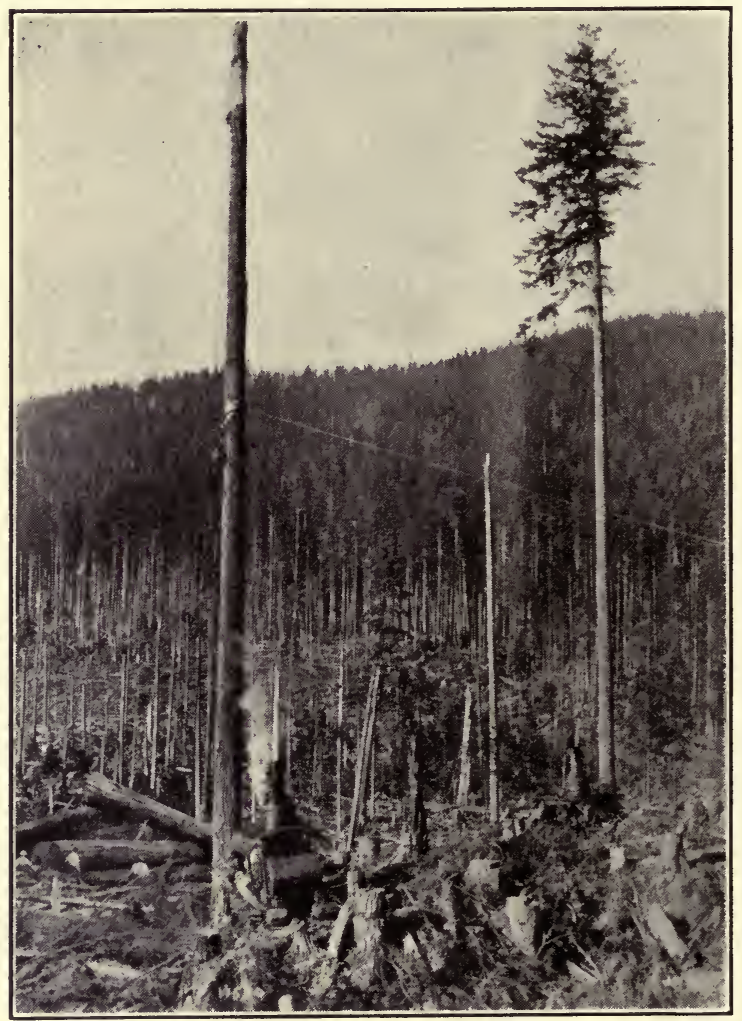

Fig. 78.-Characteristic high lead logging scene in Douglas fir timber in the Pacific Northwest. Under some conditions, these high powered engines are being replaced by Diesel tractors to skid the heavy and long logs. Photo by John D. Cress.

pine was used as a source of building homes in a large portion of the treeless praries of the Central West. Stream driving and rafting continued throughout these early days. The story of rafting on the upper Mississippi River and its tributaries, and stream driving in Michigan, is an epic in the upbuilding of the American commonwealth. Late in the nineteenth century the white pine forests were practically exhausted and the industry shifted to the South. Until this time, white 
pine was the leading species of lumber cut. The southern pine forests became the great center of production, the peak being reached in 1907. Then there was a gradual change to the Northwest as a source of lumber and a continuous decline in yearly production. The South for over 35 years has been the great center of the lumber industry, and owing to its vast areas of quickly growing pine and hardwoods in a warm and favorable climate, this region is likely to be the center of the future production of the American lumber supply.

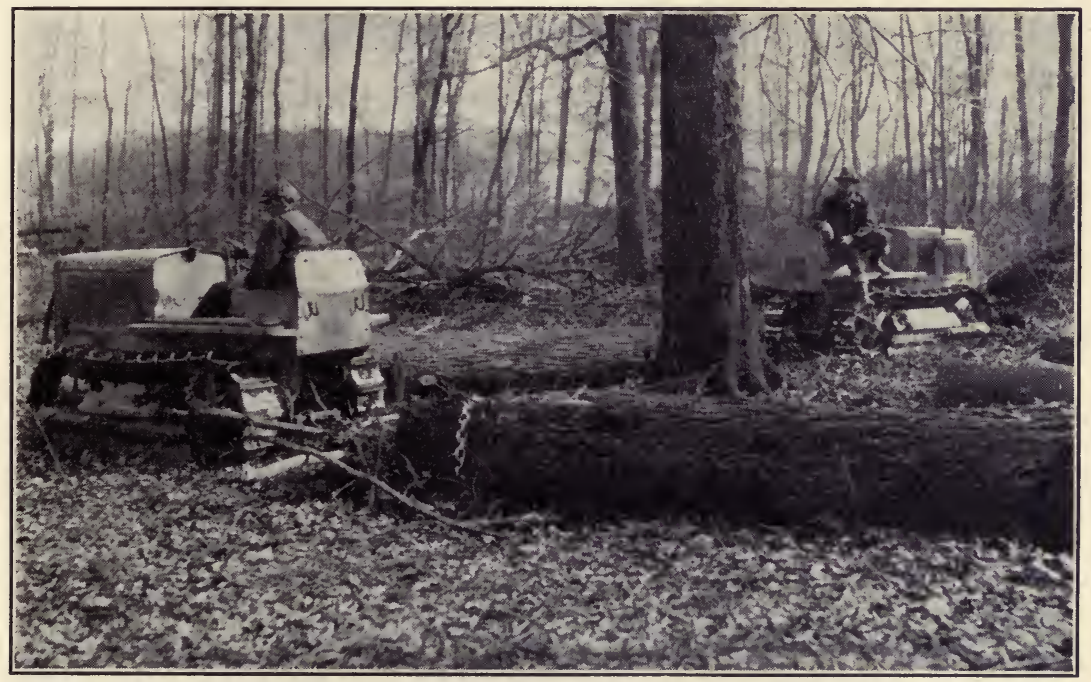

Fic. 79.-A small Caterpillar 15 h.p. tractor used in ground skidding hardwood logs in Indiana. Small and large sized logs in the East and South can be ground skidded cheaply for short or long distances by small sized tractors.

The enormous size of the timber in the Northwest caused logging procedure to change vitally. For many years, animals, chiefly horses, mules, and oxen, were used to skid the logs from the woods. Although many yoke of oxen were used in the Pacific Northwest at first, they proved to be inadequate and too slow in furnishing the great sawmills that were erected throughout the region. Gradual changes toward the mechanization of logging and improved devices in power line skidding took place. Since the World War, vast improvements have been noted in logging facilities, chiefly the introduction of the gasoline tractor which in turn is being replaced by the Diesel tractor, and improvements in power line or cable skidding. Since 1914, and especially in recent years, the motor truck has come rapidly into wide use in hauling logs from the skidding areas to the sawmills.

There are four main branches of logging, namely: 
1. Surveying, engineering, estimating, and the making of preliminary plans, together with the construction of camps.

2. The felling and bucking of the tree stem to log lengths, preparatory for transportation.

3. Minor transportation or log assemblage, generally known as skidding.

4. Major transportation or main log haul.

Camps vary in size from the small 10 -man tent camp to the permanent camps of the Far West, housing from 150 to 300 men or more,

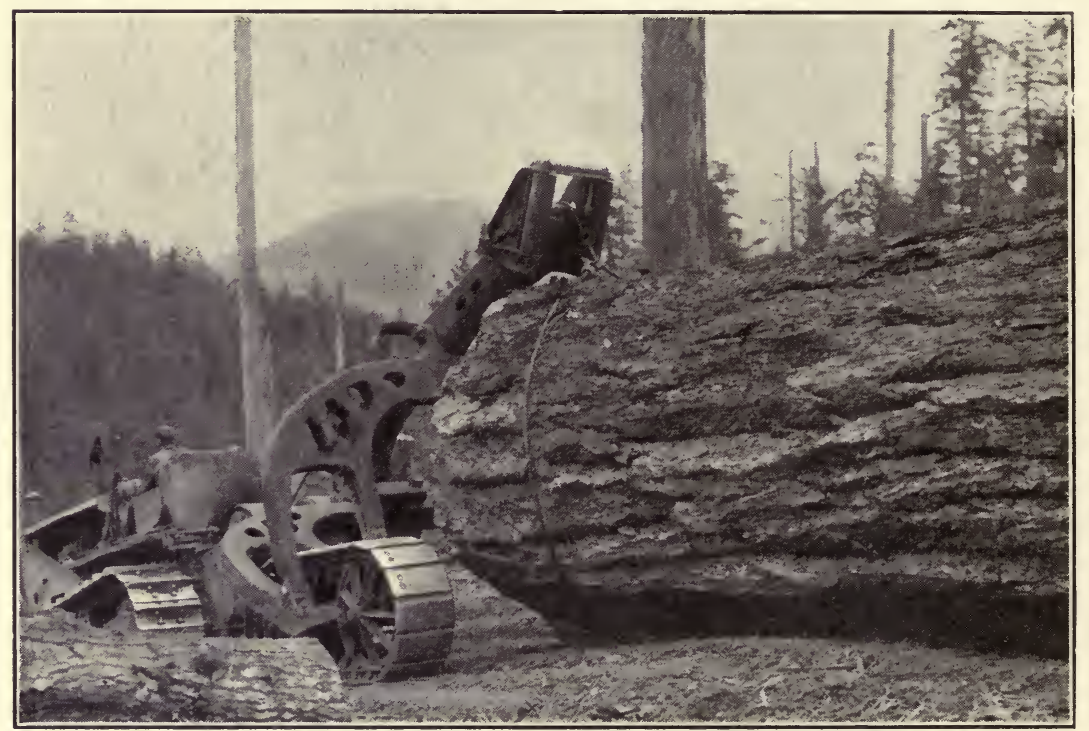

Fig. 80.-A Caterpillar Diesel 75 h.p. tractor with Hyster-Willamette arch bringing in a large size Douglas fir log 2000 feet off steep grades up to $35 \%$ in Washington. This is an unusually large size log.

such as the logging camp at Ryderwood, Washington. In the Northeast, woods labor is chiefly of the French Canadian type; in the South the Negro provides the principal labor. In the Lake States the proverbial lumberjack is largely of Scandinavian origin. In the Rocky Mountains and the Pacific Coast States mixed labor of Scandinavian, Finnish, Irish, Russian, and other origins is generally found.

The rather unsanitary, poorly constructed log camp, common in earlier days, has practically disappeared. Owing to changes in methods of log transportation, camps are generally built of lumber and have excellent sanitary and housing facilities. The best lumber camps 
are found in the Northwest where they are frequently equipped with shower baths, recreation rooms, and separate beds replacing the old straw bunks.

The location of the camp must be easily accessible to the work and on dry ground, for health and sanitary reasons; it must be convenient for toting in men and supplies, and it must possess a continuous and pure water supply.

Woods labor in the Northwest camps is generally more skilled and well paid because of the mechanical nature of logging. In other sections of the country, labor is not generally so well paid. The National

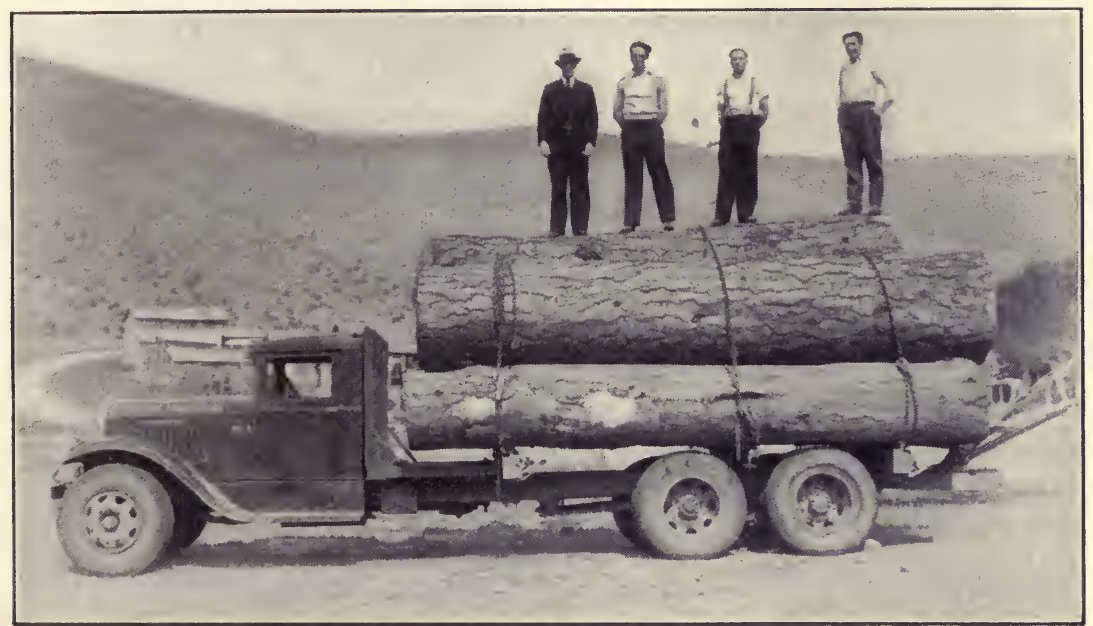

FIG. 81.-Logging ponderosa pine in Oregon. Motor trucks with or without trailers are widely used for log transportation in all parts of the country.

Industrial Recovery Act provided for improved wages, varying from a minimum of 24 cents per hour in the southern pine and southern hardwood regions, to $42 \frac{1}{2}$ cents per hour on the West Coast and these wages have generally been maintained ever since.

Trees are generally felled by making a notch with an axe and felling the tree with a two-man crosscut saw. Much lower stumps are being cut in order to save unnecessary waste. Spring boards, common in the West, are being used less frequently. High standards of felling practice are required on the National Forest timber sales. The usual log length felled in the American forests is 16 feet, but on the West Coast where power line and tractor skidding is used, log lengths of 20 to 60 feet are common. Recently several mechanical devices have been introduced for felling and bucking up the tree into log lengths. 
A portable gasoline-driven chain saw has been in successful operation in Laurel, Mississippi, for several years. These chain saws have also been used in the redwoods, ponderosa pine, and other sections of the country.

Care should be exercised in felling not to destroy young or immature growth or to shatter the tops by lodging the tree against other trees or on rocks, stumps, windfalls, etc. Logs are being taken in the tops to small sizes when market conditions are favorable. In northern white pine and Idaho white pine, logs are often taken down to 6 inches in top diameter. On the West Coast, Douglas fir is cut down to 10 to 16 inches in top diameter, ponderosa pine to 7 to 10 inches, and southern pine to 6 to 8 inches. Hardwoods are generally cut to 8 to 12 inches or larger, depending upon local conditions and market requirements.

Skidding, formerly practiced with animal power, chiefly horses, mules, and oxen, is largely done now with the tractor and horse, and in the largest virgin timber, such as Douglas fir and other West Coast woods, southern cypress, and longleaf pine, by power skidders. The tractor is a multiple-purpose woods instrument. It is used not only for skidding out logs but also for hauling in supplies and building road and railroad grades, felling trees and snags, making fire lines, plowing for reforestation, and many other phases of woods work. Tractor skidding has replaced horses in nearly every section of the country. It is also displacing power skidding in the Northwest and in the South. On many Nátional Forest timber sales, notably in California and the Southwest, power skidding is not permitted because of the great damage done to reproduction and young growth. It is generally concedcd that animals are least destructive to reproduction and immature growth in skidding, tractors do relatively little harm, but power skidding does an enormous amount of damage, practically destroying all the remaining growth on a logged area. These are very important considerations in making plans for reproducing the forest.

Many million dollars are invested in providing methods of major $\log$ transportation, also known as main log haul. Logging is primarily a problem of transportation-that of moving a bulky and heavy commodity, saw logs, from the woods to the sawmill. Major log transportation may readily be divided into land and water transportation. The latter has largely been superseded because the more accessible stands of timber have been cut, also hardwoods which do not generally float have been logged more extensively since about 1900 .

For the past several decades, railroads have furnished the principal means of transporting logs from the woods to the sawmills. They 
are the principal method of moving logs in the Pacific Northwest, California, the Southwest, the northern Rocky Mountains, and in the southern pine and southern Appalachian regions. Railroads are expensive; not only the initial construction, but also the equipment and its maintenance as well as the upkeep of the railroad itself require large expenditures. Their use is justified only on very large operations where logs must be transported for considerable distances.

Within recent years the motor truck has advanced widely in popularity because of the vastly improved systems of hard-surfaced highways and the better design and construction of motor trucks. Both these factors have resulted in much lower costs of log transportation. Except in logging large-size virgin timber on the Pacific Coast, and the virgin timber of the South and Appalachian Mountains, motor trucks are the principal means of moving logs from the woods to the mills. It is particularly adapted to small mill logging. The small sawmill produces about 70 to $80 \%$ of all the lumber produced east of the Rocky Mountains, and motor trucks are widely used in connection with them. Trucks are often used to haul logs for distances up to 50 to 100 miles. On account of their flexibility they can tap a large number of sources. Thus, farmers are selling many logs from their woodlots to supply the larger as well as the smaller sawmills. Practically all the mills east of the prairies purchase logs in the open market, and most of them are hauled by the motor truck.

Tractors are also used to transport logs for short distances, particularly in hauling logs loaded on four- six-, and eight-wheel wagons in the hardwood swamps and occasionally elsewhere. The two-long chute is common for transporting logs in the northern Rocky Mountains, particularly in northern Idaho. Various types of wagons hauled by animals or tractors are occasionally used but are rapidly disppearing from the woods.

Sled logging has decreased in importance where it was formerly a principal means of winter log haul. It is still widely used in eastern Canada and in Ontario. It is occasionally found in the Northeast and the Lake States and to a limited extent in the northern Rocky Mountains. Sleds, known as drays, log boats, and lizards, are extensively employed in skidding.

Among the chief forms of water transportation are rafts, which are common in the Pacific Northwest, in the estuaries and tidal streams of the South Atlantic and Gulf Coasts, and occasionally along our major streams. Barging logs has partially superseded rafting, particularly on an upstream haul and where wind or tidal influences may interfere with the movement of rafts. Stream driving has prac- 
tically disappeared from logging procedure in the United States. It is still the most widely used method in transporting several million cords of spruce pulpwood annually in eastern Canada. It is also practiced occasionally in Maine, New York, and northern Idaho, and for cross ties in Wyoming, Colorado, and Utah.

Flumes, which are V-shaped troughs or channels in which water flows from a reservoir or stream, are used to float logs from the woods to the sawmill or railroad. The Madera flume in California is 55 miles long. There are several flumes in the northern Rocky Moun-

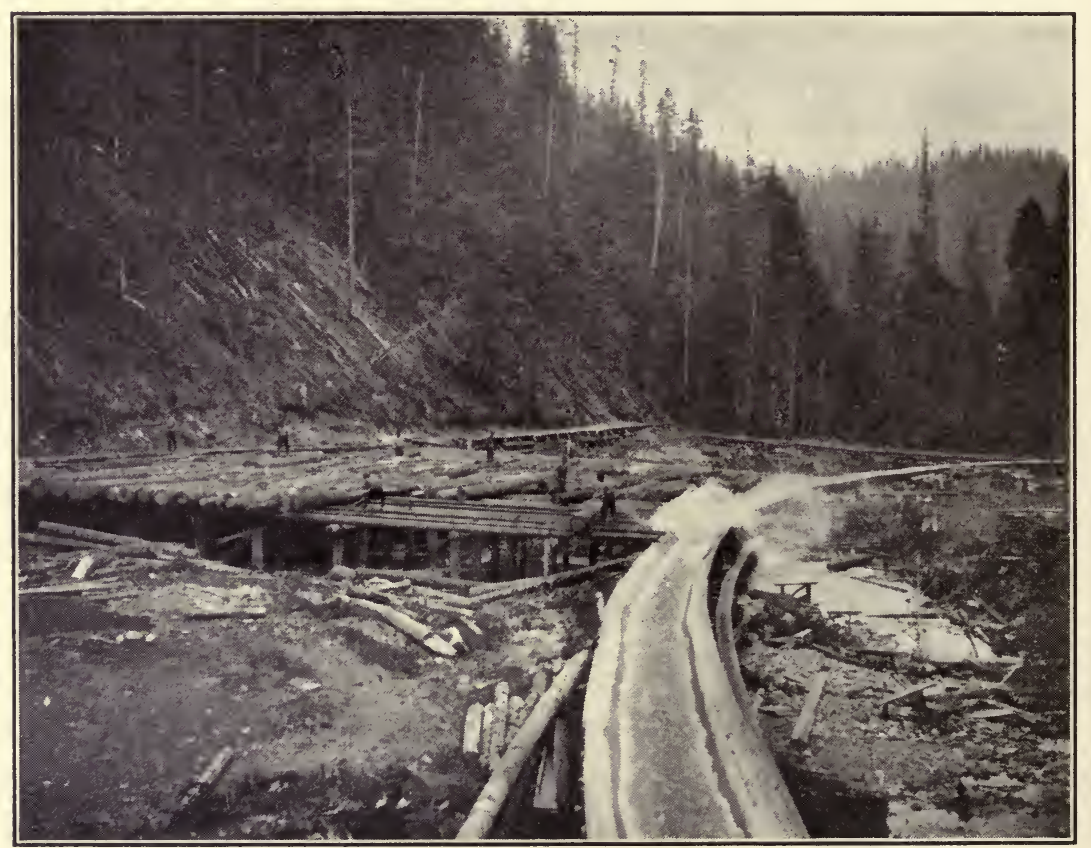

Fig. 82.-Rolling logs into flume from landing, Idaho. Logging is an important activity in connection with timber sales on several National Forests.

tains. They are gradually disappearing, however, even in the regions where they are adapted to the size of the timber, nature of topography, and climate.

Constant improvements and lower costs have marked the development of American logging practice. The forester must have an intimate knowledge and understanding of the best methods to adopt in logging any forest tract, whether a small farm woodland of 20 acres or an extensive area of 100,000 acres or more. Low logging costs increase stumpage values and thereby make forestry more attractive 
financially. Every forest presents somewhat different logging problems. The size of trees, density of standing timber, topography, climate, distance to mill or market, daily log requirements of the sawmill, and available transportation facilities have a very important bearing upon the selection of the most economical logging method to employ. Careful consideration must be given to the initial cost, maintenance, and operating efficiency of animals, sleds, tractors, and power skidders expressed in costs per thousand board feet for skidding in each region and tract. For the main log haul, a choice may be necessary between railroads, motor trucks, tractors, chutes, wagons, flumes, barges, and rafts.

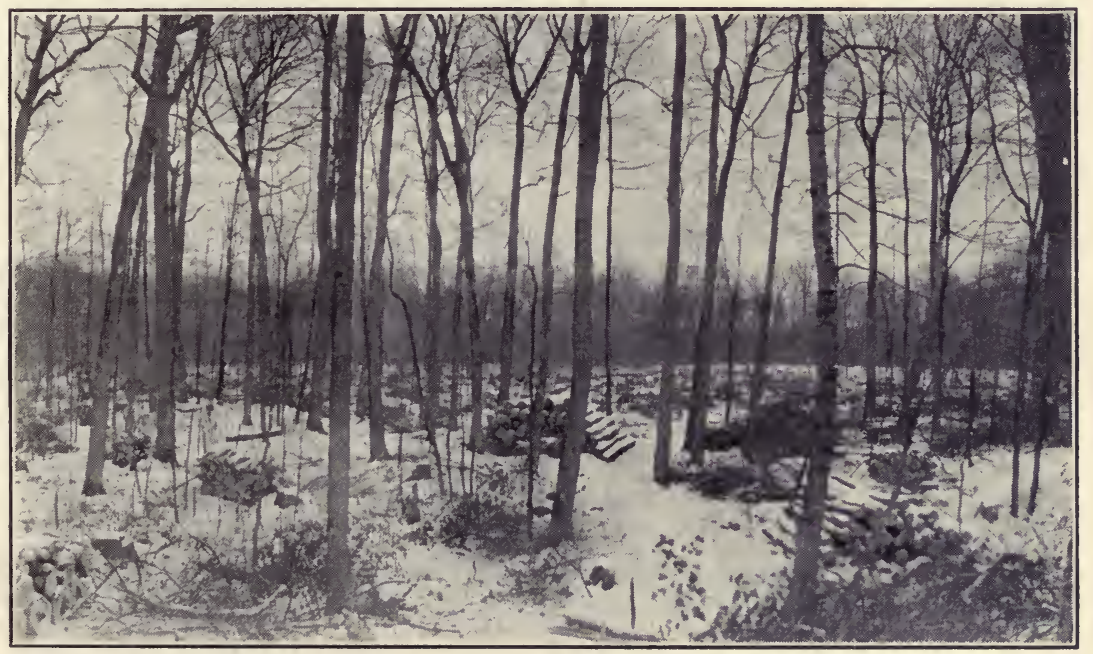

Fig. 83.-Selective cutting in northern hardwoods, in Upper Peninsula of Michigan. Only the largest and defective trees were removed leaving the younger and thrifty trees to grow more rapidly. Cuttings were used for sawlogs, pulpwood, fuelwood and other products.

\section{SELECTIVE LOGGING}

Within recent years, American silviculture has developed more progressively and actively along the lines of selective logging than in any other direction. It is apparent that American economic and silvicultural conditions lend themselves to selective logging better than to some of the European methods of silviculture which are conventionally described under the general heading of Silviculture-Natural Reproduction.

Selective logging is the partial cutting of the forest to flexible diameter limits to increase present profits and to perpetuate and im- 
prove the forest for the future. It embodies the very essence of forestry principles as applied to standing merchantable timber. It satisfies both present and future requirements in forest management. It is constructive, as contrasted with former destructive methods of forest exploitation.

On logging operations, only those trees are cut which will yield an immediate cash return. Formerly there was little if any scientific determination of what size trees would turn out profitable when logged,

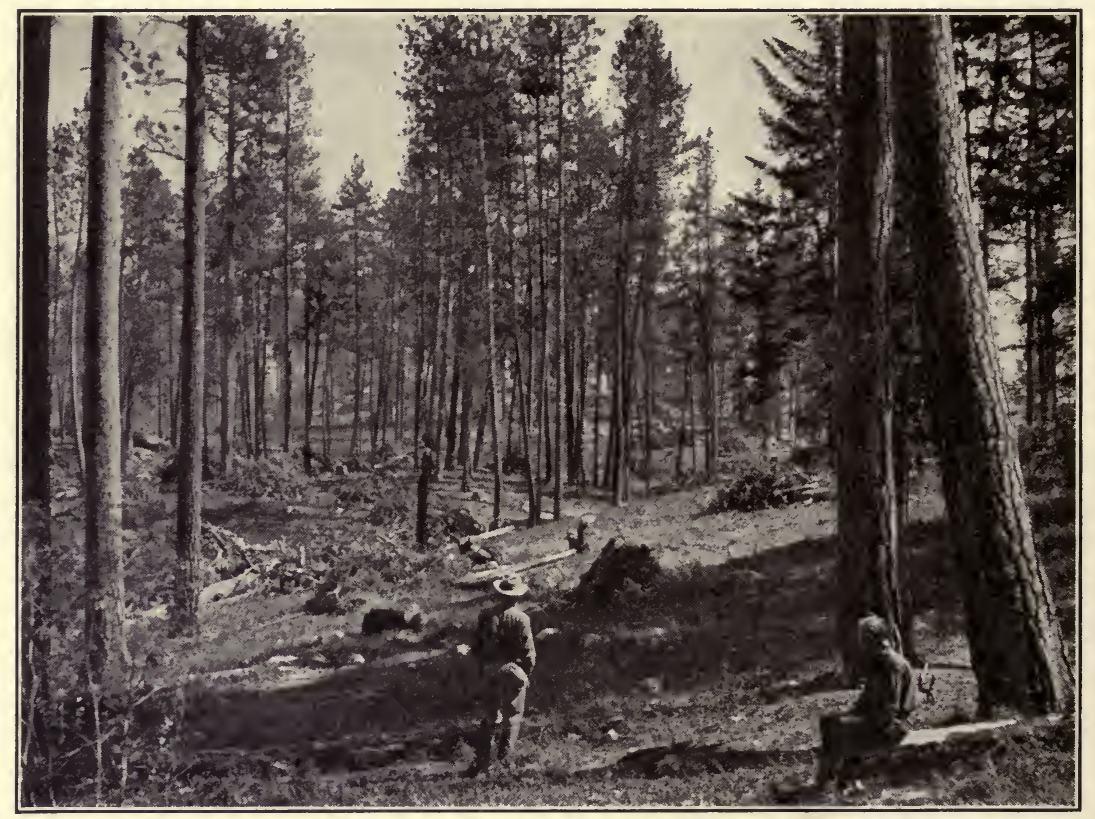

Frg. 84.-A selectively logged area of ponderosa pine in the Bitteroot National Forest, Montana. Stumps were cut low, brush and logging débris carefully piled and burned and close utilization of the tops was practiced. The remaining thrifty trees grew much more rapidly when the canopy crowding was released. Trees were generally cut to a flexible diameter limit of about $19^{\prime \prime}$.

manufactured, graded, and seasoned. The question of selectivity may apply to individual trees, groups, or areas. It is a combined silvicultural and utilization measure, although its objectives are primarily of utilization. On National and other public forests, it serves both purposes. It has been unintentionally practiced in a crude and unscientific manner for many years on farmers' woodlots throughout the East and on many private operations. It recognizes the established fact that logging costs per thousand board feet increase with decreas- 
ing tree sizes. Conversely, the larger the tree the lower the cost of logging per thousand board feet. Lumbermen have heretofore roughly estimated the size of trees to be cut. Often they have "skinned" the areas, believing that cutting all trees, even to small sizes, would result profitably. There is a distinct but variable relation between tree sizes and profits. When lumber prices are relatively high and attractive,

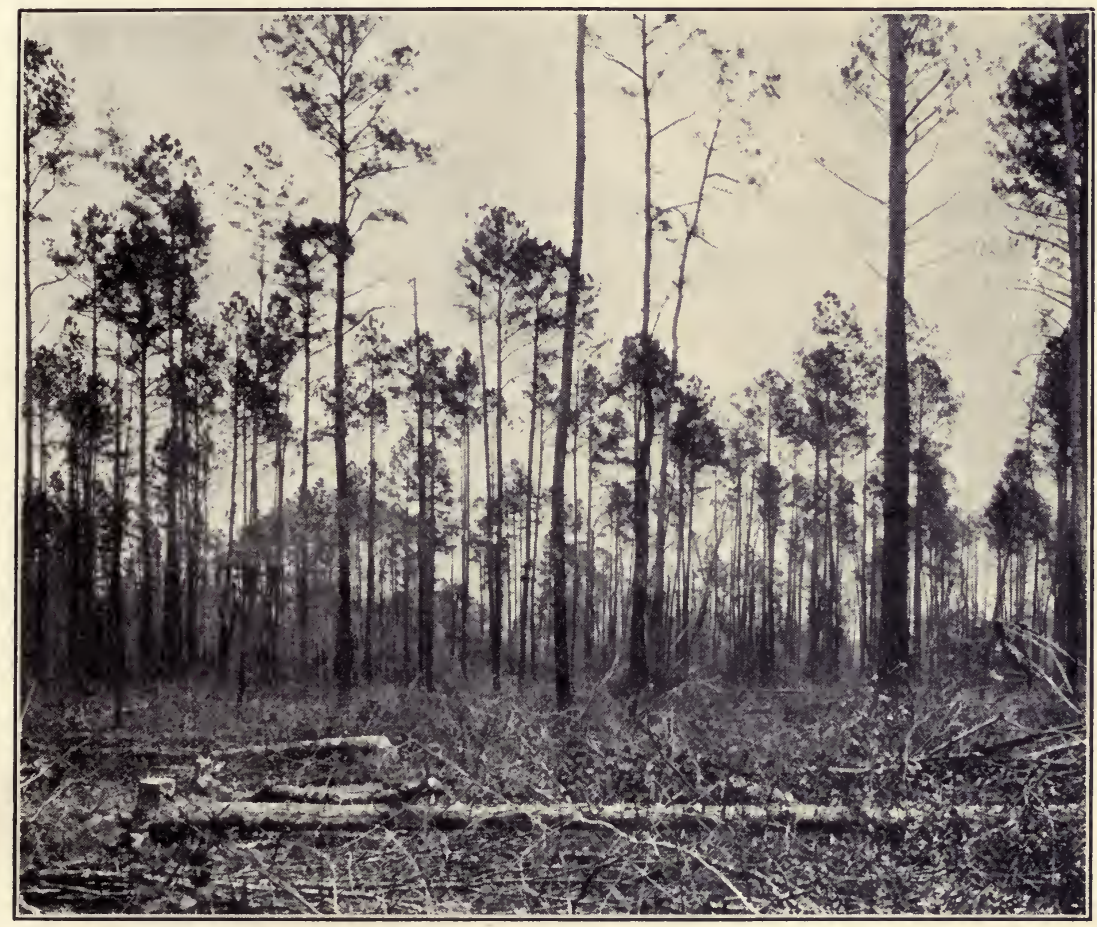

FIG. 85.-Loblolly pine selectively cut in the eastern coastal plain and along the south Atlantic Seaboard. Selective logging is a combined silvicultural and utilization measure, which serves both present profits and future growth and fulfills the very essence of good forestry practice.

small trees may be profitably logged. Too frequently, however, trees are cut when at the most rapid period of growth and when lumber markets are glutted with timber cut from trees below commercial sizes, especially in the South, Lake States, and the Northeast.

Several studies have recently been made by Zon, Garver, Gibbons, Brundage, and others to determine the size of trees which can be profitably logged.

Selective logging is being introduced in several forest regions. Test logging plots have been established in order to ascertain facts. Se- 
lective logging has made real progress on the Goodman tract in Wisconsin and on plots of the Camp Manufacturing Company in eastern Virginia, the Crosset Company in Arkansas, the Weyerhaeuser Companies in Idaho and the Northwest, and several companies in California, Washington, Oregon, and Idaho.

Generally, foresters mark individual trees to be cut. The diameter sizes marked for cutting may vary with the species and with local conditions, but studies have indicated that the best sizes for cutting are 34 inches or larger, d.b.h., in Douglas fir; 40 inches in sugar pine;

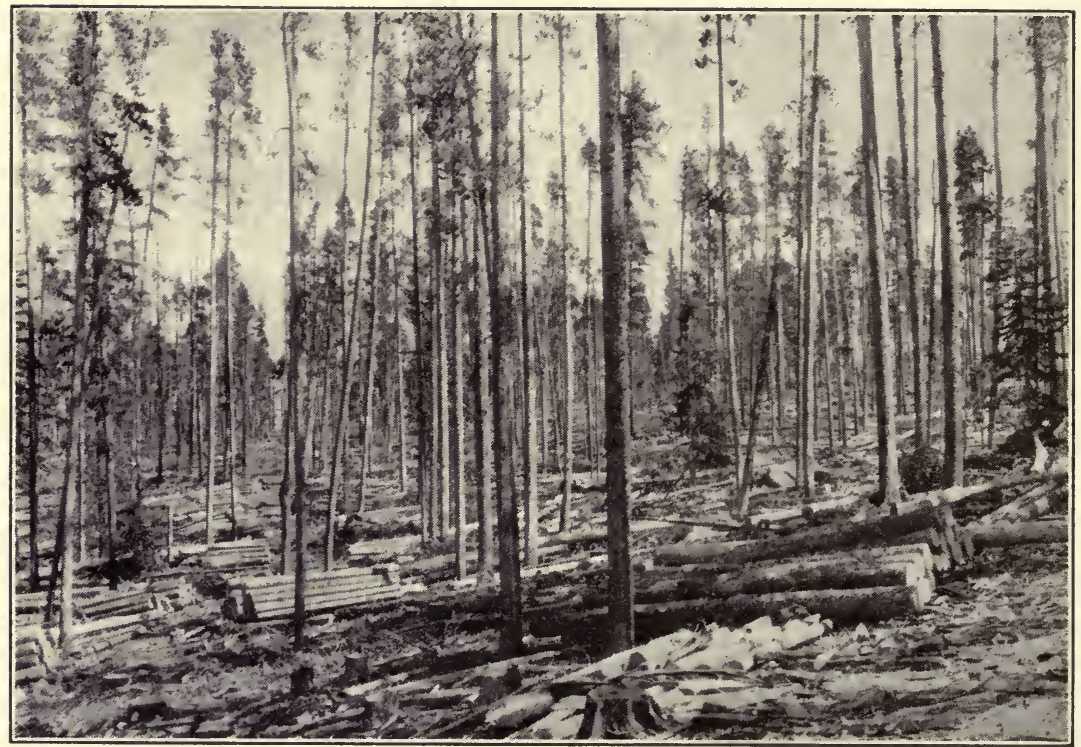

FIG. 86.-Lodgepole pine stand selectively logged in the Rocky Mountains for mine props, cross ties, poles and saw logs.

20 inches in ponderosa pine in western Montana; 18 inches in shortleaf pine in Arkansas, loblolly pine in the Southeast, red oak in North Carolina, and beech, birch, maple, and hemlock in the Lake States.

The advantages of selective logging are:

1. Only trees yielding a certain profit are cut. Higher grades of lumber which command the best market prices are obtained because only the largest and best trees are removed.

2. Felling, bucking, swamping, and skidding costs are reduced. Other logging costs, such as hauling, are reduced as well.

3. The condition of the forest is improved because the favored species 
are left in the stand and better-quality reproduction is assured for the future.

4. Young timber on the area is left in good growing condition, thus substantially putting the forest on a sustained yield basis.

5. Better fire protection is assured by leaving a smaller amount of slash and débris.

6. It prolongs the life of lumber operations and thus contributes to greater stability and permanence of sawmills and other forest industries.

Among the disadvantages may be cited the following:

1. For some forms of small products such as cross ties, pulpwood, chemical or acid wood, fuelwood, posts, small poles, and piling, there is no marked advantage in cutting only the larger trees.

2. Greater skill must be exercised in removing the timber. Supervision, marking, etc., must be done by skilled foresters, and the area must be carefully cruised, mapped, and studied before the plan is made effective.

3. Immature timber must be protected and taxes continuously paid upon it. Some local assessors may not reduce taxes proportionately with the removal of the best standing timber so that the financial accumulation may be greater than the volume growth.

4. It is not especially applicable to large, even-aged, or intolerant forests where a considerable number of the trees are of large sizes and grow so densely that the small trees cannot be protected in the felling process.

5. It cannot be practiced on logging areas cut under enforced liquidation of standing timber assets. This is a powerful factor in the Pacific Northwest region where the burdens of interest and taxes have intensified exploitation without any thought of the future.

The above disadvantages, however, are not universal and are not entirely unsurmountable even in some of the regions where they may apply.

Selective logging is probably practiced more than any other form of logging in our National Forests, especially in the pine forests of California, Oregon, and Idaho.

The Southern Forest Experiment Station has made studies of the costs of necessary forest inventories and marking in connection with putting in a system of selective logging and sustained yield management on private properties. The costs of a detailed inventory, including a $100 \%$ cruise of trees $13^{\prime \prime}$ d.b.h. and over, and marking trees to be cut on about 3000 acres of southern pine, were $\$ 0.103$ per m.b.f. of 
timber marked to be cut or $\$ 0.054$ per m.b.f. of the total stand. There were 21 million b.f., $\log$ scale, or 7000 feet per acre, on the tract. Trees for cutting were marked with white paint on four sides.

\section{MANUFACTURING AND CONDITIONING}

The manufacture of lumber is probably the oldest, most typical, and one of the largest American industries. For many generations it has supplied building materials for our homes, as well as many

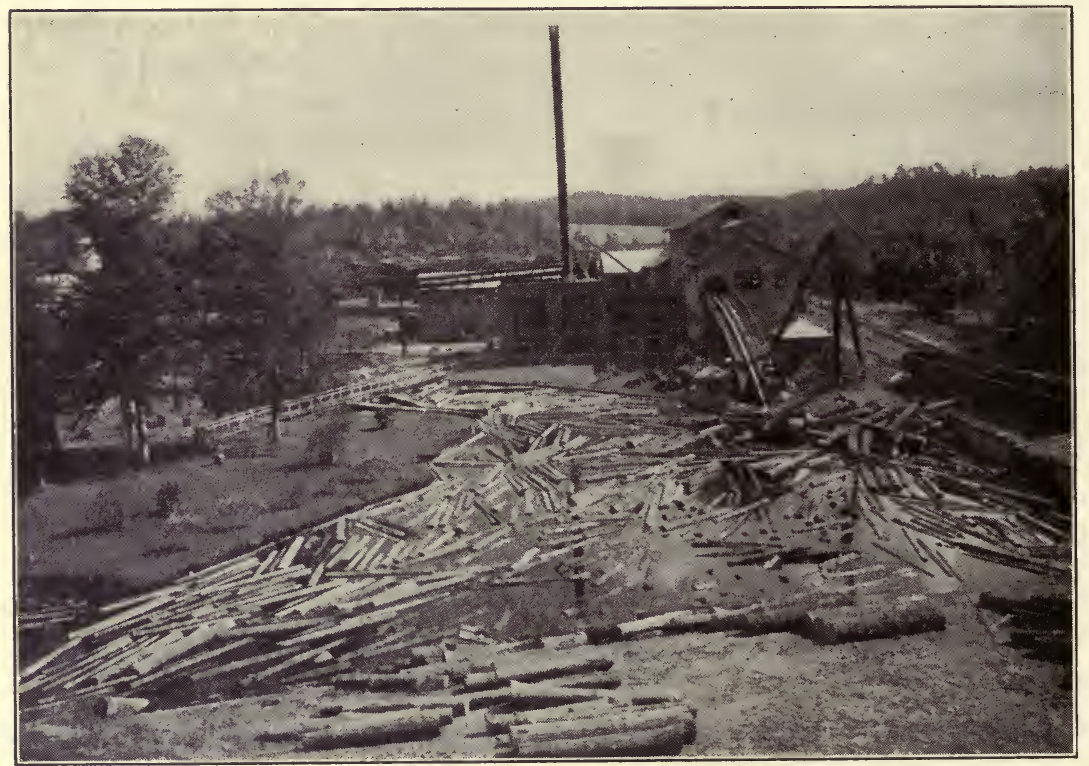

Frg. 87.-Typical large size band sawmill cutting hardwoods near Kingsport, Tennessee. On the right is the logging railroad used to haul logs from the woods. The log dump and railway are also shown on the right. Hardwood mills seldom use $\log$ storage ponds as shown in this picture. An overhead cable-way is used to convey the logs to the jack ladder which hoists them to the upper floor of the sawmill. In the foreground are logs delivered by motor truck.

other products that come into intimate relationship with our daily lives. During the rapid expansion in population in the last century there was an enormous development in lumber manufacture. This continued until the peak of production in 1907, when 46 billion b.f. were produced in about 40,000 sawmills. After 1929, there was a rapid recession in production to about $101 / 2$ billion b.f. in 1932 , and a small gradual increase since. 
Lumber has been produced chiefly from our great sawmills, some cutting as much as 200,000 to $1,000,000$ b.f. per day each, in two shifts. Saw logs pass through a very interesting procedure to convert them from round shapes into square and flat forms used in commerce and industry. On delivery from logging operations in the woods, logs are generally stored in a $\log$ pond, from which they are elevated to the second floor of the sawmills by a continuous chain known as a jack ladder. They are rolled down a log deck to a saw carriage, on which they are fastened against knees and headblocks by a setter

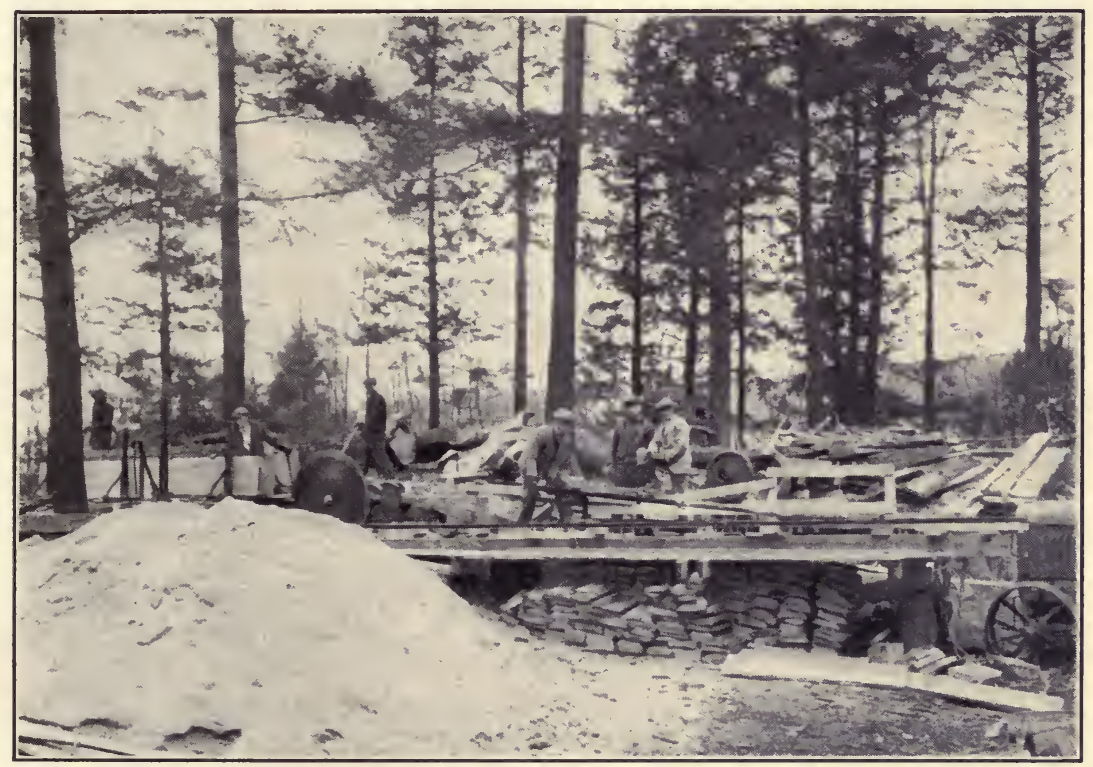

Fig. 88.-Typical small portable sawmill cutting about 5000 b.f. per day with 5 men. On the left is shown the log deck, saw carriage, and circular saw. Large pile of saw dust in foreground. On the right is tractor which furnishes power for the sawmill. Much lumber is made throughout the East, Lake States and South by these small sawmills.

and his assistant. The carriage conveys the logs through the saw, of circular type as used in most of the small mills or a band saw.

Most of our lumber is sawed by large band saws. These are continuous bands of steel which travel at the rate of about 900 feet per minute and make successive cuts of lumber or timber from the log. The lumber is passed through an edger, which trims off bark, knots, or other defects to make the two edges parallel. Then it goes to the trimmer saws which cut off the pieces at the desired lengths. From the trimmer saw, the lumber passes on to the grading or sorting table 
where it is graded according to freedom from defects and blemishes, and is sorted for piling. All the $2^{\prime \prime} \times 4^{\prime \prime}$ pieces $10^{\prime}$ long are placed in one pile, the $2^{\prime \prime} \times 6^{\prime \prime} \mathrm{s}, 16^{\prime}$ long are placed in another pile, and the $1^{\prime \prime} \times 10^{\prime \prime}$ boards in still another pile. There should be a separate pile for each size and grade.

After the lumber has been air-seasoned in the pile for four to ten months or more, it is ready for shipment to market. Many mills are putting green lumber directly from the sawing department to the dry kiln, which may be either a compartment or a progressive type of kiln, and subjected to certain temperatures and humidities to eliminate moisture without degrading or destroying the full value of the lumber product. About 50\% of the weight of wood is moisture. This must be largely eliminated before the wood is further manufactured or used. Some lumber is first air-seasoned, as in hardwoods, and later kiln-dried before being finally manufactured into furniture, flooring, doors, and interior finish.

Principal Species of Lumber and Producing States. The principal species of lumber produced in our sawmills in order of importance are: (1) southern pine; (2) Douglas fir; (3) ponderosa pine; (4) oak; (5) white pine, including both northern and Idaho; (6) hemlock, including both eastern and western; (7) red gum; (8) cypress; maple; (10) spruce; (11) redwood; (12) tupelo; 13) poplar; (14) birch, and several miscellaneous varieties.

Southern pine comprises about $30 \%$ of all our lumber, and Douglas fir about an equal amount. The first two species therefore comprise about $59 \%$ of all our lumber, and the first three, $72 \%$.

Hardwood lumber production has recently fallen off from about $21 \%$ of all lumber produced in 1919 to about $14 \%$, and conversely, softwoods have increased in volume from $79 \%$ to $86 \%$.

The principal lumber producing states in order of importance are:

(1) Washington; (2) Oregon; (3) California; (4) Louisiana; (5) Alabama; (6) Mississippi; (7) Texas; (8) North Carolina; (9) South Carolina; (10) Florida; (11) Arkansas; (12) Idaho; and (13) Virginia. The first two states represent $38 \%$ of the total lumber output, producing largely Douglas fir and western hemlock. These two states produce $96 \%$ of all the Douglas fir; California produces largely ponderosa pine and considerable quantities of redwood and sugar pine. The next eight states in order produce principally southern pine, and they are also the centers of hardwood output. On account of the vast available areas for southern pine and the favorable climate and quick rate of growth, southern pine will always be a very important 
lumber on our markets. It is widely produced in the eleven southern states from Virginia to Texas, in Oklahoma, and Arkansas. Oak, cut from a number of species of both white and red oak, is produced chiefly in Tennessee, Louisiana, Mississippi, and Arkansas; red gum comes chiefly from South Carolina, Louisiana, and Mississippi; and maple from Michigan, Wisconsin, and New York, mentioned in order of importance.

\section{COSTS OF PRODUCING LUMBER}

The costs of producing lumber have advanced in this country over a period of years on account of increasing labor costs and stumpage values. Manufacturing methods have become much more refined and efficient. The business of manufacturing lumber has contributed employment and wages to many hundred thousands of people throughout the country, especially in the South and Far West, which have become the great centers of production. In 1929, the southern and western states produced over $85 \%$ of the total lumber supply of the nation, and this came largely from the two states of Oregon and Washington, and the four southern states of Mississippi, Louisiana, Alabama, and Texas.

The following table shows typical costs for producing lumber. It will be noted that the charges incurred in logging and manufacturing are less than half of the total cost of producing lumber.

ITEMS

Cost PER M.B.F.

Logging

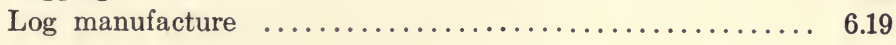

Total logging and manufacturing costs $\ldots \ldots \ldots \ldots \ldots$

General and administrative expenses ............. 9.96

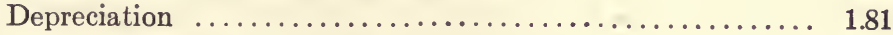

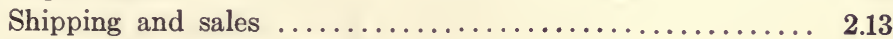

Other undistributed costs $\ldots \ldots \ldots \ldots \ldots \ldots \ldots \ldots \ldots \ldots . . . . \ldots 8$

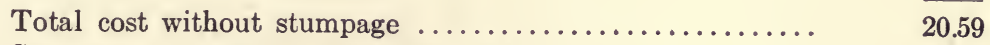

Stumpage and cost of purchased logs $\ldots \ldots \ldots \ldots \ldots \ldots \ldots . .5 .42$

Total cost of lumber ..................... $\overline{26.01}$

This is a typical example based upon average figures of many mills in the Southern Pine Association. 


\section{LUMBER DISTRIBUTION}

During the early days of the country, lumber was consumed within short distances from the sawmills. With the cutting out of the vast virgin timber resources of the Northeast and Lake States, lumber was produced at considerable distances from the great consuming markets which are generally in the centers of population and industrial activity. In 1914, the average rail haul for lumber from mill to market was 360 miles; in 1924, 725 miles; thus the distance was doubled in a decade. Lumber coming to the Northeast generally travels an average distance by rail of 840 miles; to the Lake States, 910 miles; to the Central States, 1515 miles. The average rail haul from the Pacific Northwest to the East is about 2600 miles, and the intercoastal water haul via the Panama Canal from the West Coast to the Atlantic seaboard is about 6000 miles.

New York and Chicago with their heavily populated suburban districts and adjoining cities normally consume about $20 \%$ of the total country's lumber supply. The metropolitan district of New York City generally consumes about 2,400,000 m.b.f. annually, and the Chicago district about 2,200,000. Chicago is the most important rail shipping center, but about one-third of the lumber reaching Chicago by rail is reshipped to other destinations. Los Angeles probably leads the world in the volume of lumber received and handled by water. Until recently, relatively little of the ponderosa and Idaho white pines were moved long distances. Approximately one-third of these two important species are now moved into the eastern territory. Of the large volume of Douglas fir, about $13 \%$ is used within the producing territory, $23 \%$ goes to California, $34 \%$ to the North Atlantic States, largely by water shipment, and the balance of $30 \%$ is moved into the Middle West. Lumber began to actively move through the Panama Canal from the Pacific to the Atlantic Coast in 1920 when about 50 million b.f. were moved. The peak of these movements was over 2 billion b.f. in 1928. In 1933, it had dropped to 860 million b.f.

Approximately $70 \%$ of our lumber is sold through wholesalers who serve as middlemen between the lumber manufacturers and the retailers and industrial or other consumers. About 70 to $80 \%$ of all lumber is retailed to the ultimate consumer. The retailers purchase direct from the sawmills as well as through wholesalers.

The United States is the most important country in the world in its volume and value of exports of lumber and sawn timbers. Other important lumber-exporting nations are Russia, Sweden, Finland, and Canada, in that order. Russia shipped a maximum of about $66,000,000$ 
b.f., largely of spruce, to this country in 1930. The volume in 1933 was only about $22,000,000$ b.f., which is exceedingly small compared with the large total consumption of lumber. The exports of Douglas fir exceeded those of any other species and totaled $474,000,000$ b.f. in 1933. Southern pine, which has been the leading species of lumber exported for many years, is now second in importance and totaled $341,000,000$ b.f. Oak is the third most important lumber exported. Red gum, ash, yellow poplar, and some other species are also exported.

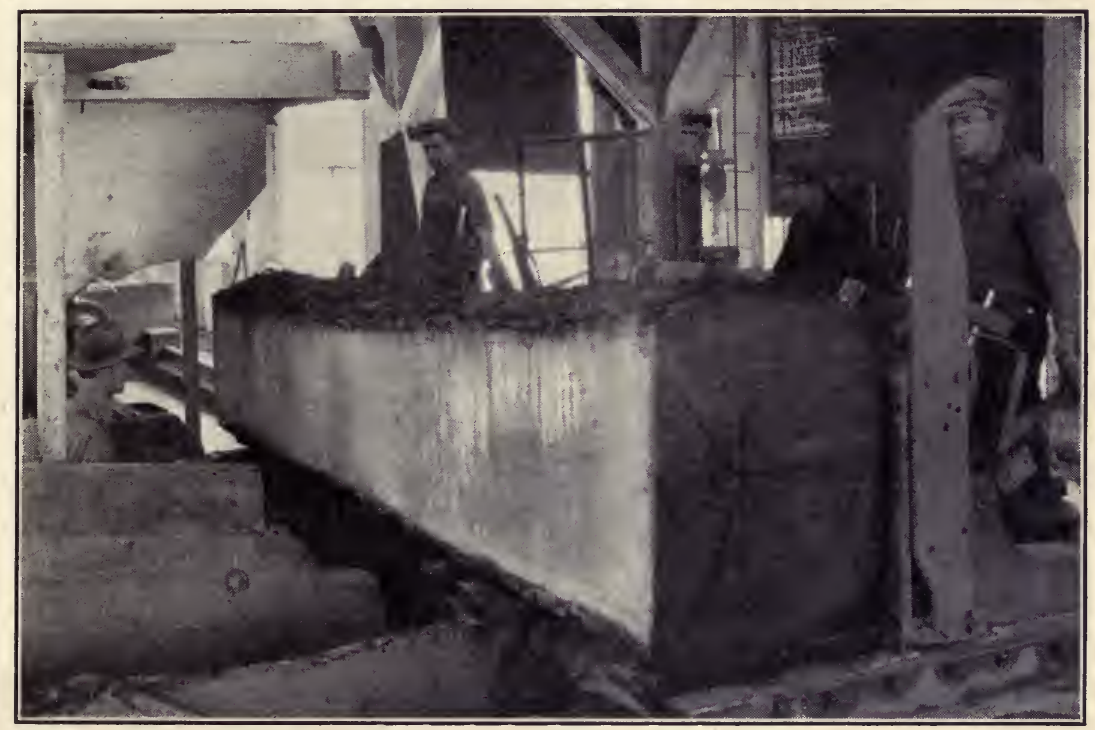

Fig. 89.-Interior of single band sawmill cutting large sized yellow poplar log. On the left stands the sawyer who operates levers which control the movement of the saw carriage and the log turner known as a "nigger." On the immediate right of the sawyer is shown the band saw. On the right of the picture is shown the setter and two doggers who, on signal from the sawyer, set the head blocks for the desired width of lumber to be sawed.

Redwood and Port Orford cedar are important species exported from the West Coast. Hickory and ash are in demand for the manufacture of skiis in Scandinavia. Argentina is the most important country seeking lumber from the United States. China and Japan are also extensive importers, particularly of Douglas fir. The United Kingdom is the most important buyer of hardwoods, taking about $70 \%$ of all hardwood exports from this country.

The total value of lumber and wood exports from this country in a recent year was over $\$ 47,000,000$. It is important that we produce a sufficient volume of lumber and other forest products to sell at a 
relatively low cost to the people of this country as well as to build up a large and profitable export trade. It is believed that the United States will always have available for export a surplus of lumber and other forest products.

In 1924 over $3,667,000$ cars were loaded with forest products. This figure had dropped to 899,000 cars in 1932 , but there has been substantial increase since. This volume of business is a very important factor in maintaining our vast network of rail transportation systems throughout the country. Of all the forest products loaded by the railroads, about $40 \%$ are composed of lumber, lath, and shingles; logs, $24 \%$; pulpwood, $11 \%$; railroad cross ties, $4 \%$; posts, poles and piling, $6 \%$; and the balance of $15 \%$ is composed of fuelwood, cooperage materials, boxes and crating, and miscellaneous commodities.

The country's railroad freight bill in 1924 for transporting lumber, timbers, and other forest products was about $\$ 408,000,000$. The people and the industries of New York spend approximately $\$ 40,000,000$ annually in normal times for lumber and other forest products shipped into that state. Illinois pays about $\$ 30,000,000$, California $\$ 20,000,000$, Pennsylvania $\$ 23,000,000$, and Michigan $\$ 20,000,000$. 


\section{CHAPTER XII}

\section{FOREST UTILIZATION-WOOD USES AND ECONOMICS}

\section{PROPERTIES AND THEIR RELATION TO USES OF WOOD}

Wood varies widely in its structure. The variations found in its structure form the basis for the identification of wood and largely decide the general character of its utilization.

The principal features of wood structure involve the physical, mechanical, and chemical properties. These, in turn, generally determine the uses for each species. Some woods such as oak, longleaf pine, and Douglas fir are strong, stiff, and durable and therefore make excellent construction timbers; the cedars, cypress, redwood, and chestnut, being exceedingly durable, make excellent poles and posts; spruce has long, strong fibers and is relatively free from resinous and gummy materials and is accordingly adaptable for the production of paper; mahogany has a most attractive and beautiful grain, seasons well, does not warp or twist out of shape, and is therefore esteemed for high-grade furniture, finish, and cabinet work. Elm, being tough, makes a good vehicle and hoop wood; white oak is impervious to liquids and does not exude a disagreeable odor or flavor to the contents, so it is a very satisfactory wood for barrels and other forms of tight cooperage.

Each wood has definite qualities, properties, and characteristicscolor, weight, grain, strength, durability, stiffness-which distinguish and identify it from others. The character of the utilization of each species depends upon these properties, as well as upon its cost and availability.

Some of our species have risen to such high price levels or have become so scarce that substitutes have been introduced to take their places. Ingenious but generally unsatisfactory methods have been devised to imitate the color, and grain of the more valuable woods such as black walnut, mahogany, rosewood and Circassian walnut. However, these imitations are not generally perfect reproductions and are easily recognized by the trained eye. Methods of graining cheap woods to imitate quartered white oak or other woods have been devised but are usually considered unsatisfactory. In the same way, metals painted 
to resemble wood have proved to be expensive and unattractive in appearance.

Every forester should have an accurate knowledge of wood structure and should know how to identify the many different species that appear in our American markets.*

Wood structure refers to the relative size, shape, appearance, and form of the wood elements. These characteristics vary with each species. This explains why some species are heavier, stronger, tougher, and stiffer than others, why some are cross or straight grained, hard or

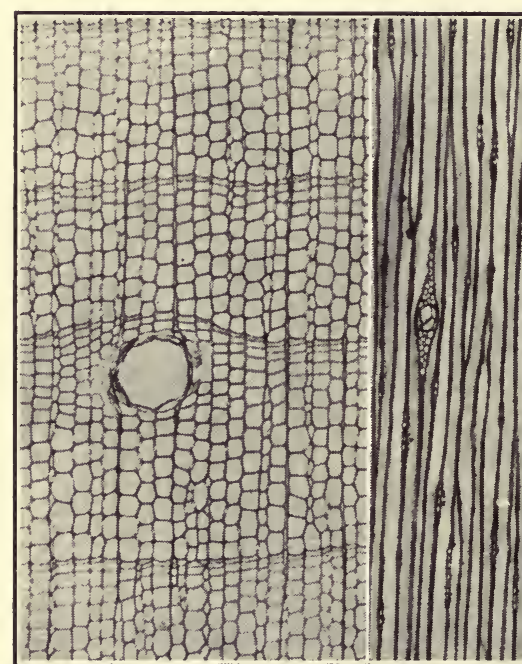

A.

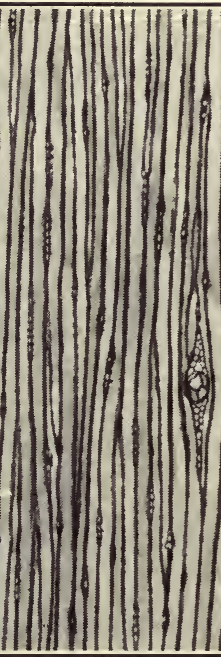

B.

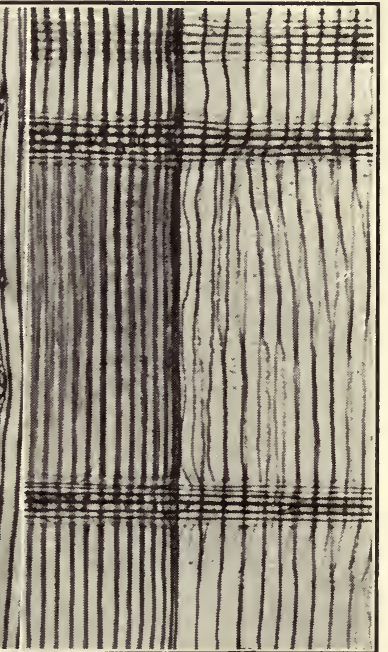

C.

Fig. 90.-Photographs of wood as viewed under the microscope. A. Across the grain. B. Along the grain tangent to the annual rings. C. Along the grain at right angle to the annual rings. Resin canal is shown as the large opening in $\mathbf{A}$. This view also shows $3 \frac{1}{2}$ annual rings. $A$ is sugar pine and $B$ and $C$ are northern white pine. These two species and western white pine compose the white pine group. Photos by H. P. Brown.

soft, and why some have a tendency to check and split whereas others season rapidly and without injury. For example, the structure of oak with its wide wood rays is responsible for its pleasing effect when it is quarter sawed and polished to display the grain. The sapwood differs considerably from the heartwood in structure and appearance. Some species have a very thin sapwood, such as redwood, catalpa, red cedar,

* For further treatment of this subject, see "Identification of the Commercial Timbers of the United States," by H. P. Brown and A. J. Panshin, McGraw-Hill Book Co., New York, 1934, and "Identification of the Timbers of Temperate North America" by S. J. Record, John Wiley \& Sons, New York, 1934. 
and yew. Young trees have a much higher percentage of sapwood than old, mature veterans. Hickory, maple, ash, beech, and some of the pines generally have large portions of their trunk in sapwood. In some species, like cottonwood, willow, spruce, the true firs, and hemlock, there is comparatively little difference in appearance and value between the heartwood and sapwood. The usual darker color of heartwood is caused by the deposition of certain tannins, gums, resin, etc. Hence, the heartwood is commonly heavier, harder, and more durable, and it contains much less moisture. Therefore, heartwood is generally much more valuable than sapwood. In some phases of utilization, however, as for spools, spokes, and handles, only sapwood is desired. For example, handles used for axes, hammers, hoes, and shovels, cut from second-growth hickory and ash sapwood, are preferred on our markets. White maple, or the sapwood of the maple tree, is sometimes preferred to the heartwood. In many species, sapwood may degrade lumber sawed from it. For example, two grades may be cut from the same red gum tree. The lumber cut from the heartwood is known as red gum lumber, whereas that cut from the sapwood is generally referred to as sap gum. Sapwood may be treated with preservatives more readily than heartwood. This is very important in some species. Most of our railroad cross ties, poles, posts, and frequently piling and mine timbers are treated with chemical preservatives to prolong their life in service.

Species with wide wood rays such as oak, beech, and sycamore present a beautiful silver grain when sawed radially or at right angles to the annual rings. Wavy and curly grain are frequent variations in the growth of many species, especially in hard maple and occasionally in redwood and yellow birch.

Custom has been responsible for naming our broadleaved or deciduous trees hardwoods, and all our narrow leaved evergreens as conifers or softwoods, but these terms are susceptible of further explanation. Both are misnomers when taken literally. Some conifers such as larch and cypress are not evergreen but deciduous, dropping their leaves every autumn. Furthermore, many hardwoods are much softer in their wood structure than some of our softwoods, and some softwoods like larch, longleaf pine, and Douglas fir are much harder and heavier than some of the so-called hardwoods such as basswood, willow, cottonwood, yellow poplar, catalpa, buckeye, and red gum.

The hardwoods are generally divided into two broad classifications, that is, those which are ring-porous, like oak, ash, hickory, elm, chestnut, and catalpa, and those which are diffuse porous-red gum, yellow poplar, willow, birch, maple, basswood, and beech. The former 
have wide bands of large pores in the springwood. The diffuse porous woods are more homogeneous and continuous in their structure and texture. Approximately $79 \%$ of the annual lumber production from our forests is of coniferous growth which satisfies the large demand for lumber for construction and general building purposes. The hardwoods are more specialized in their applications, being used chiefly for furniture, cabinet work, implement and vehicle stock, interior finish, flooring, etc.

A knowledge of wood structure is very important for understanding how best to season lumber and other forest products. About 50\% of the total weight of green wood consists of water. Seasoned by usual methods, lumber generally contains from about 15 to $20 \%$ moisture, and thoroughly kiln-dried lumber only 6 to $12 \%$ moisture. The purposes of seasoning are to decrease the danger from decay and therefore increase the durability of wood, to prevent warping, twisting, checking, and shrinkage after the wood is placed in service, to increase the strength and stiffness and decrease its weight and therefore economize on transportation charges. When green or freshly sawn, lumber is exceedingly susceptible to fungus and insect attacks. Lumber is ordinarily seasoned by exposing it to the air with adequate facilities for the passage of air currents to assist in the elimination of moisture. Much more lumber is being kiln-dried to hasten the process of seasoning than formerly. Adequate temperature and moisture control must be maintained in order to secure the best results. The character of wood structure must be thoroughly known in order to regulate the methods of artificially seasoning wood by drying it in kilns. The rapidity of seasoning varies with the structure of the wood, the size and shape of the lumber or piece to be seasoned, as well as the method of seasoning and piling. For example, hardwoods are much more difficult to season than softwoods; $4^{\prime \prime}$ stock seasons much more slowly and with more difficulty than $1^{\prime \prime}$ lumber. White pine dries more quickly than oak because of differences in structure and density. Softwoods generally require from two to five months for air seasoning, whereas hardwoods may require from six to ten months. In kilndrying processes, lumber may be seasoned in a few days. Usually temperatures of $150^{\circ}$ to $180^{\circ} \mathrm{F}$. are maintained to dry lumber properly in kiln. The humidity in the air of the kiln must also be carefully regulated.

Weight or density of wood also varies very widely. Fuel value is in almost direct relationship to weight. Weight influences transportation charges to the market, and it has already been explained that both logs and lumber may be shipped long distances to market. 
Hardwoods cannot be floated or driven on streams because of their weight and the likelihood of sinking. Some of our heaviest hardwoods are hickory, persimmon, white oak, hard maple, beech, ash, and elm. Among the heaviest softwoods are longleaf pine, western larch, and Douglas fir. The light-weight hardwoods include the cottonwoods, aspen, yellow poplar, butternut, willow, chestnut and catalpa; lightweight softwoods are redwood, the cedars, white pine, eastern hemlock and the true firs.

Strength, hardness, cleavability, flexibility and toughness * are important mechanical properties of wood.

The chemical utilization of wood within recent years has emphasized the importance of the chemical properties of wood. Each species varies both in its physical and in its chemical characteristics. The field of chemical utilization has only begun as far as its ultimate possibilities are concerned. When wood is dried in extreme temperatures, it is found to contain about $99 \%$ organic matter and about $1 \%$ inorganic matter. The latter comprises the ash when wood is burned. Wood is found to contain largely carbon and oxygen with a small amount of hydrogen and very small quantities of nitrogen, potassium, sodium, calcium, and magnesium. The wood fibers consist of a skeleton of cellulose which includes varying amounts of lignin, tannin, resins, and gums. Cellulose is readily converted into some of the simpler sugars. $\dagger$

Durability is a very important quality of wood; it may be described as the ability to resist decay. Durability is very important in wood which is to be used for railroad cross ties, poles, posts, mine timbers, piling, and foundations, which are susceptible to decay. Durability is often the determining factor in the value of some species that may be exposed to certain soil, weather, or moisture conditions conducive to decay. It is the purpose of the preservative treatment of wood to lengthen its life in service. Wood does not naturally decay. Specimens have been taken from piling driven by Caesar in crossing the Tiber River near Rome about 2000 years ago which are still sound. All decay is caused by fungi or bacteria which live on the constituents of the wood, causing dry rot, heart rot, and punk in both living trees and lumber and wood materials manufactured from trees. Fungi live and propagate when environmental factors such as

* For further information on this subject see "The Mechanical Properties of Wood" by George Garratt, John Wiley \& Sons, New York, 1931.

$\dagger$ For further information on chemical properties of wood see "The Chemistry of Wood" by L. F. Hawley and L. E. Wise, Chemical Catalog Co., New York, 1926. 
heat, moisture, and oxygen are favorable. Whenever any or all of these are absent, decay is not possible. Among the most durable species are black locust, the cedars and cypress, redwood, and black walnut. White oak, cherry, persimmon, longleaf pine, and western larch are also very durable. Among the least durable species are black gum, basswood, aspen, beech, willow, sycamore, and lodgepole pine. Other species occupy intermediate positions.

\section{THE PRINCIPAL SOURCES OF WASTE IN THE FOREST AND AT MANUFACTURING PLANTS}

Great wastage has necessarily attended the conversion of our trees into usable forms. A large portion of the trees felled in the American forests is still wasted owing to the unfavorable economic conditions and failure to find a profitable outlet for waste materials. Probably from 70 to $80 \%$ of our wastage has been unavoidable. Much improvement has marked the development of both logging and manufacturing processes within recent years, so that this enormous loss has been partially eliminated. Even under ideal conditions, as in European practice, only about 80 to $90 \%$ of the total volume of trees is utilized except under extremely favorable conditions which exist in some portions of western and central Europe. Hodgson has determined that more than 6 millions of cords of softwood, or 42 cords per acre, are yearly left unused in the woods on logging operations in the Douglas fir region. The degree of utilization is directly related to market prices. High prices mean more complete and efficient utilization.

The chief sources of waste in the woods are the generally nonmarketable tops, limbs, and branches; the cutting of unnecessarily high stumps; also breakage and shattering in felling and log making; defective trunks; and improper measuring of log lengths (perhaps to avoid crook, crotches, large knots, and other defects). Further waste results from the customary practice on the part of the public in requiring lumber to be cut in even lengths instead of odd and even lengths, unnecessarily liberal allowances for trimming log lengths in the woods, losses in transportation, chiefly in driving logs in streams, and losses incident to insect and fungus damage when logs are left for considerable lengths of time during the warm season.

The principal losses in manufacturing are due to the large slabs cut from the sides of the logs at the sawmills, wide kerf cut by circular saws instead of band saws which are used in the larger and more modernly equipped mills, loss in bark which is occasionally used for fiber boards and for insulation purposes as in some redwood, losses due 


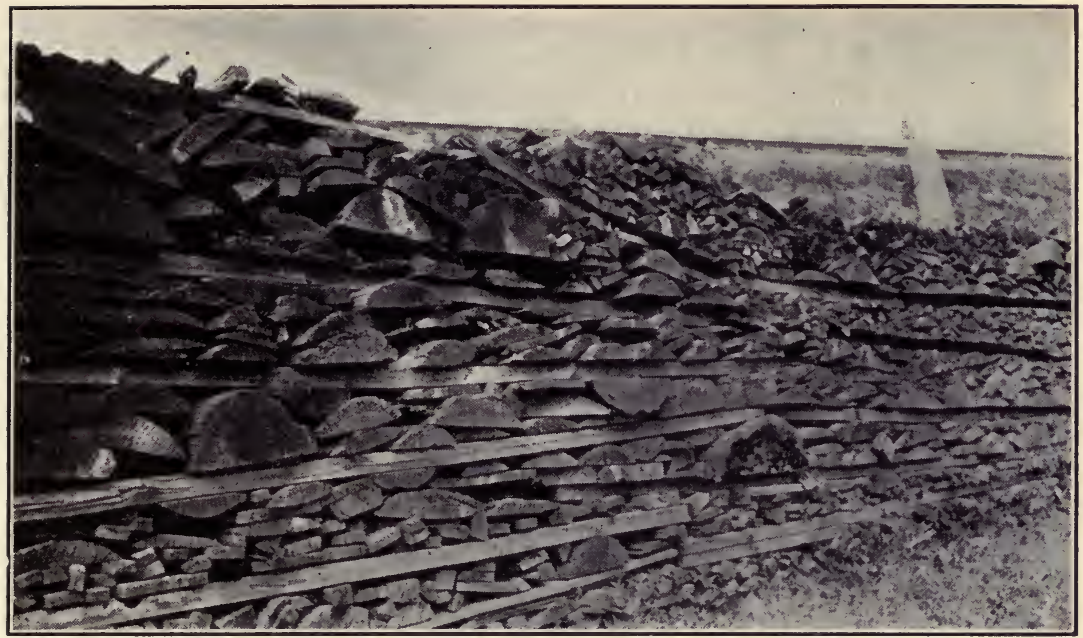

Fig. 91.-Slabs cut from logs in process of converting them into lumber at the sawmill. Formerly wasted these slabs are now re-manufactured into lath and box lumber and also used for paper pulp and for fiber boards.

to edging and trimming lumber in the sawmills, and seasoning and remanufacturing. These losses may be summarized as follows:

Percentage of
Total Wood
Wood Losses
Volume Wasten

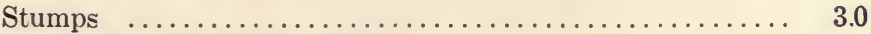

Tops, limbs and branches $\ldots \ldots \ldots \ldots \ldots \ldots \ldots \ldots \ldots . \ldots \ldots$

Defective and decayed trunks and boles shattered in felling $\quad \mathbf{5 . 5}$

Miscellaneous, as improper log lengths, transportation loss en route to destination, decay in storage, etc. ..... 2.0

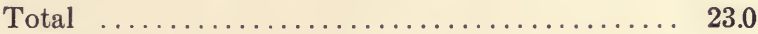

\section{Manufacturing Losses}

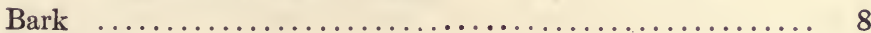

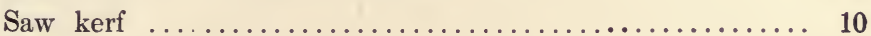

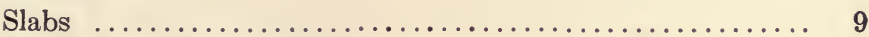

Edgings and trimmings $\ldots \ldots \ldots \ldots \ldots \ldots \ldots \ldots \ldots \ldots \ldots$

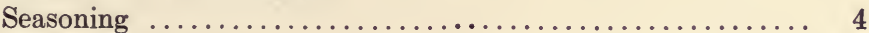

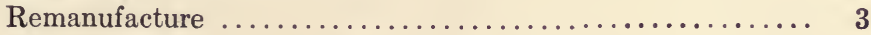

Miscellaneous ............................... 1

Total ............................... 43

Total woods and manufacturing losses $\ldots \ldots \ldots \ldots \ldots 66$

Thus, only about one-third of the trees actually felled in the woods is converted into some usable commodities. 
The greatest wastage in conversion of our forests to usable forms is found in the large timber of the Pacific Coast region, especially in such species as Douglas fir, western hemlock, Sitka spruce, and redwood. The least wastage occurs in northern white pine, Idaho white pine, and some of the more valuable hardwoods, such as oak, yellow poplar, ash, hickory, and black walnut. The greatest wastage is in species of low stumpage values, and the least in those of high values.

\section{ECONOMIC CONDITIONS DETERMINING DEGREE OF UTILIZATION}

As indicated elsewhere, only a small part of the trees felled in the American forests is ultimately utilized. Economic and social influences have played a most important part in the use of forest products. The progress of the American lumber and associated industries has been marked by great wastage. The factors which determine the degree to which our trees may be utilized, both in the woods and at our sawmills and other wood-conversion establishments, are:

1. Demand for material reflected in prices. The extent of utilization follows price levels very closely. Increasing prices mean more complete utilization, and conversely, low prices indicate increasing wastage. In logging virgin white pine in Michigan in the last century, frequently only butt logs were utilized because the public would pay a low price for even the best clear boards. Lumber cut from the second, third, or fourth logs, etc., could not be made and sold at a profit. The public is to be charged with this great wastage in previous years. Today, some of our finest and largest virgin timber in Douglas fir commands only about $\$ 2$ per m.b.f. stumpage, so the wastage is exceedingly great.

2. Product must be salable. Even if a demand does not exist for a certain commodity or species, a potential market may exist. Merchandising methods must be developed to furnish a profitable outlet for unknown or little-used species. Tupelo and black gum, white fir, beech, and western larch were formerly marketed with great difficulty. Through research and improvement in marketing methods an outlet was found for these and many other species.

3. Transportation costs may be the greatest barrier to the use of any material. Wood is a commodity of great bulk and weight. Millions of cords of good wood are wasted annually on our logging.jobs because it costs too much to transport it to a profitable market. Millions of cords of good pulpwood are annually wasted on the West 
Coast. If the big market for pulp and paper were on the West Coast instead of the East, all this material might be successfully utilized. Transportation costs are probably the greatest single barrier to complete utilization.

4. Form, size, and condition must lend themselves to utilization. Enormous quantities of sawdust are wasted annually because its form and condition make it unadaptable to any large commercial use. From one-tenth to one-fifth of the total volume of our logs is turned into sawdust. Only a small part of the slabs, edgings, and trimmings from our sawmills can be profitably used.

5. Custom, prejudice, and tradition. American people have been unwilling to use knotty, wormy, or stained lumber for many purposes. Today one finds many beautiful rooms furnished with knotty paneling, wormy oak and chestnut, and pecky cypress. Architecturally these are considered most beautiful and attractive. Custom demands that softwood boards be cut in even lengths and widths, instead of odd and even feet and inches. This results in tremendous wastage. Many substitute materials have improperly and unfairly replaced the wooden shingle.

6. Laws affecting the use of lumber and other wood products. In many communities, ordinances are in effect to restrict or terminate the use of lumber and other materials made from wood. In some cases this may be justified because of the fire hazard, but in others not at all. The growth of large urban centers in this country has naturally restricted the use of lumber and shingles in house building and general construction. The use of wood very closely follows density of population. Legal barriers, however, may play a very important part in the utilization of lumber and other forest products.

\section{INDUSTRIAL FOREST POLICIES}

Considerable progress in forestry and in the development of communal life has been made by a number of large industries that depend upon wood as their major source of raw material. Several large communities which are largely dependent upon the forest as a permanent source of supplies have been established. These industries have contributed much to the stability of employment as well as to the prosperity of these communities, and the regions in which they are located. Among the outstanding examples of these centers are: Laurel, Mississippi; Canton, North Carolina; Bogalusa and Urania, Louisiana; Aberdeen and Longview, Washington; Cloquet, Minnesota; Rumford, Maine; Winchenden, Massachusetts; Tupper Lake, New York; 
Kingsport, Tennessee; and Crosset, Arkansas. Many others could be mentioned in most of the forest regions.

The program of major activities in pursuing a forest policy for many of these forest industries has generally been as follows (these were in effect before.Article $\mathrm{X}$ of the National Industrial Recovery Act of 1933 heretofore mentioned was promulgated) :

1. Waste prevention through close utilization. It is obvious that the prevention of waste both in the woods and in the mills reduces the drainage on the forest supply. Efforts to accomplish these objectives are directed chiefly to reduce the heights of stumps to a minimum, cutting as far into the tops of the trees as economically possible, reducing losses in transportation, particularly in connection with the railroad hauling, stream driving, fluming and chuting, and maintaining storage conditions of logs and other products so that rot will not cause unnecessary wastage. Many paper, fiber board, box board, distillation, and specialty plants have been installed to utilize woods and mill refuse that would otherwise be wasted.

2. The prevention of forest fires is of prime importance for the success of any forestry enterprise. Many companies have set up separate fire prevention or suppression organizations, with patrolmen to maintain a continuous watch over the timberlands and to establish depots of tools and fire-fighting equipment which can be rushed to the scene of action at a minimum of time. These companies generally cooperate effectively with state and federal protective agencies. Both moral and financial support is generally contributed to better fire protection.

3. Scientific cutting of merchantable trees with a view of obtaining a second growth of desirable species as quickly as possible. These methods are still largely in an experimental stage of development. In. general, the forest areas that have been cut over have responded favorably to these cutting methods, notably in the pulpwood operations in Maine, New York, and the northern portion of the Lake States. In some regions with adequate rainfall, efficient fire protection may be the most important governing factor in obtaining satisfactory natural reproduction. Selective logging is a form of scientific cutting most generally adopted in the South, the Lake States, the Rocky Mountains and the Pacific Coast States. Even this may be said to be still in an experimental stage.

4. Forestry educational campaigns to arouse the interest of the public in forestry. A more general and popular respect for the value of forests is inculcated both among the school children as well as the 
older people. Signs pointing out that forests mean wages and business are frequently seen in forest regions. The public is rapidly becoming forestry minded. It is coming to appreciate that forests, through the industries that are dependent upon them, mean payrolls, which in turn affect trade, banking, transportation, and many other forms of business. An aroused public sentiment may readily affect legislation.

5. Growing of millions of trees in nurseries. This is probably the most impressive feature of the forestry activities of many companies. Tree nurseries have been established and maintained by a large number of industries to provide stock for planting areas that have been denuded of natural reproduction by fire, severe cutting practices, or from any other cause. Many companies have an added objective to stimulate local interest in planting idle, abandoned, and barren lands which are suitable only for growing timber. Many companies are dependent upon farmers and other small woodlot owners to grow and supply pulpwood, saw logs, and other raw materials for their industries. Nurseries have also been installed on an experimental basis to determine costs and procedure. Many of these have proved to be very successful.

\section{DEVELOPMENTS IN REDUCING WOODS AND SAWMILL WASTE}

Within recent years much progress has been made in reducing the enormous wastage incident to the conversion of our primary forest products, chiefly saw logs, into lumber and other usable forms. Among measures adopted may be mentioned the following (some are concerned exclusively with woods or sawmill waste, whereas others involve both):

1. Installation of paper and fiber board mills to utilize woods and sawmill waste, chiefly in the South and the Pacific Northwest. The mills recently located in the Northwest utilize large amounts of sawmill waste. A large fiber plant at Laurel, Mississippi, uses great quantities of southern pine mill waste. Many of the pulp mills, notably in the South, utilize largely woods waste and small materials which would otherwise be lost.

2. Improvements in meeting consumers' demands at the source of lumber supply. Many plants and factories are being installed in connection with sawmills to supply automobile parts, implement and machinery parts, chair and furniture parts, and many other supplies and specialized forms which had previously been manufactured at considerable distances from the sawmills. This has meant the reduc- 
tion of much sawmill waste, saving of freight charges, and the more complete and efficient utilization of our available timber supplies.

3. The use of band saws and Swedish gang saws as introduced by Oxholm in place of the circular saws. Approximately $10 \%$ of the total volume of saw logs goes into sawdust. Circular saws generally convert about twice as much wood into sawdust as the band saws or Swedish gang saws do.

4. Lower stumps and closer utilization in the tops. Many springboards are being abandoned in felling big timber in the Northwest and in California. Forest Service timber sales have been notable for their insistence upon complete utilization of the trunks of merchantable
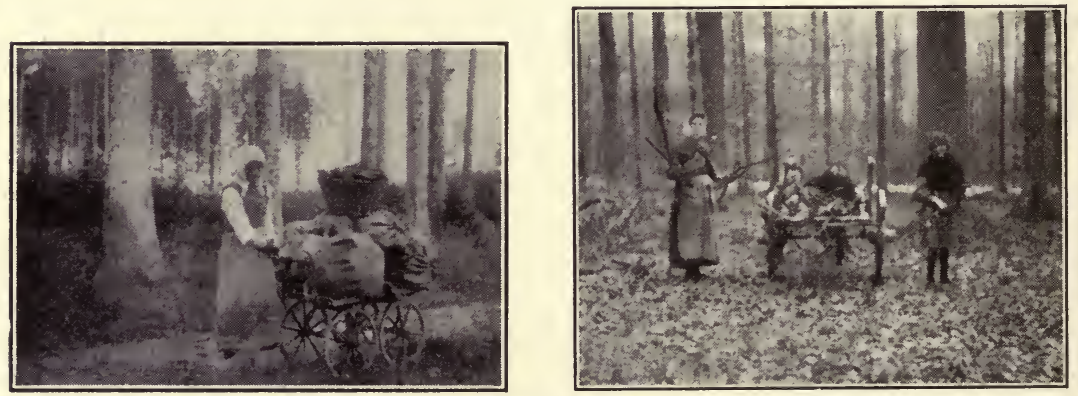

FIG. 92--Familiar scenes in European forests where peasants are permitted to gather the twigs, branches and other forest litter for fuel. This illustrates intensive forms of utilization where economic conditions justify them. On the right is shown the forest of Soignes, Belgium, composed chiefly of beech. On the left is a spruce forest in Switzerland being naturally reproduced. Photos by the author.

trees by taking tops to as small a diameter as possible, and by cutting low stumps.

5. The manufacture of broom and other handles, lath, toys, and novelties from slabs, edgings, and other sawmill waste. Formerly much of this material was wasted or consumed at considerable expense by the installation and operation of large and expensive waste burners.

6. The installation of box board crating and shook factories at or near the source of lumber supply. About $13 \%$ of our total lumber production goes into wooden containers to serve the fruit and vegetable trade of the South, California, and the Northwest. Enormous quantities of shooks are manufactured. Although this practice has been in effect for many years, recent increased efficiency has meant the elimination of much of the former waste in cutting defective or 
low-grade lumber into box shooks. New England is also an important center for the manufacture of box materials from second-growth white pine.

7. The use of pecky cypress and No. 1 and No. 2 common grades of lumber for knotty panels. The sound and wormy grades of chestnut and oak are also used for panelling and decorative treatment. Thus what was formerly considered poor or low-grade lumber has found very effective application for club, dining, office, and other rooms. Architecturally, knotty panels have met with considerable popular favor.

8. Manufacture of hardwood dimension, that is, small squares of hardwood used for chair rungs, furniture parts, etc. These are generally clear cuttings from common grades of lumber. Considerable advance has been made in the reduction of waste through the medium of hardwood dimension stock.

9. More skilful and careful felling in the woods to prevent breakage and shattering of tree trunks. Bonuses are sometimes paid for careful felling, and likewise penalties are exacted for careless work on logging operations.

10. Fuelwood from sawmill waste. Considerable amounts of the sawmill waste are utilized in the East, North, and many sections of the South and West for fuel. In the Pacific Northwest, about one and one-half million cords of sawmill waste are annually sold for fuelwood, according to Hodgson. This material comes largely from slabs, edging, and trimmings at the sawmills. More recent development has been the use of hogged fuel in hoe and office building furnaces. This has provided an outlet for 182 million cubic feet of lumber worth a million and a half dollars, according to Hodgson.

Coal is scarce and expensive in many sections of the West and Northwest. Hogged fuel used with forced draft has proved to be very successful in western Washington and western Oregon.

11. Sawdust is being increasingly used for refrigeration, for horse bedding, ice packing, floor coverings, and packing and shipping of various commodities in barrels and other containers especially in the North and East.

12. The increasing use of the portable band saw. These have been used in North Carolina, Alabama, and Virginia. A New York manufacturer has recently put them on the market. This band saw cuts a kerf of $3 / 32$ inch compared with $1 / 8$ inch for the usual band saw and from $1 / 4$ to $3 / 8$ inch or more for the circular saw.

13. Miscellaneous. The bark of some species, notably that of California redwood, is shredded and used for insulation and packing. 
Hemlock and white oak bark as well as tanbark oak are also widely used for tanning purposes.

In some sections briquettes have been made from sawdust and other sawmill waste. The Weyerhaeuser Company has recently marketed a briquetting device. Many novelties and souvenirs have been made from redwood bark, such as pinholders. Ash trays, pin trays,

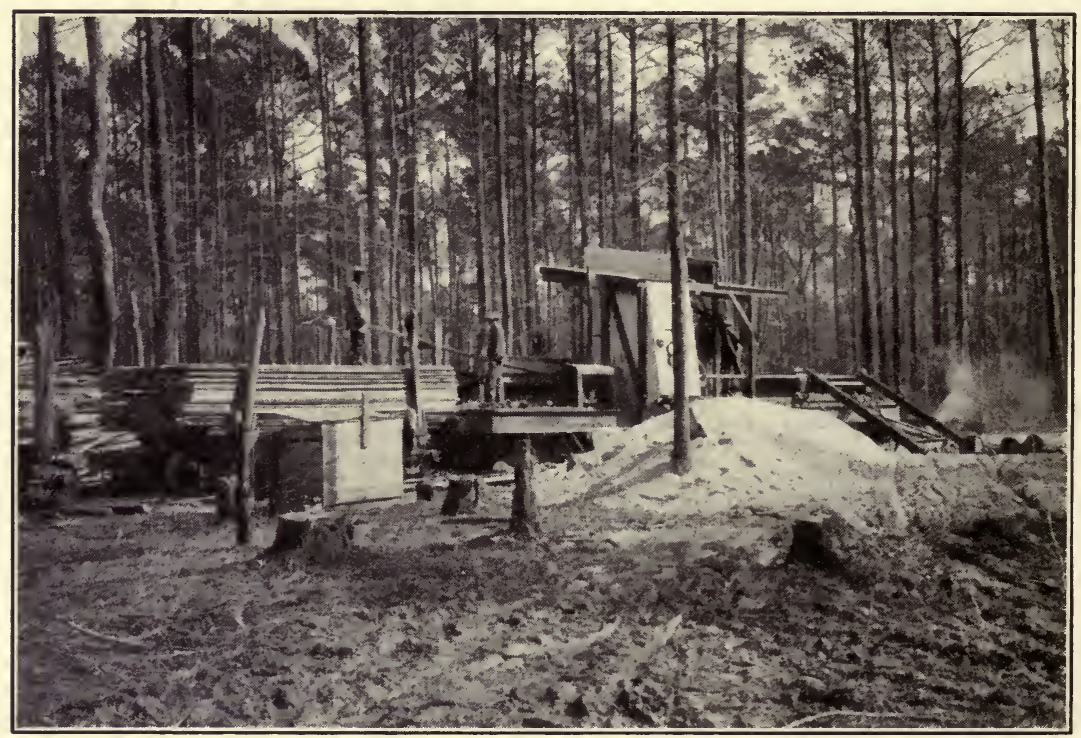

Fig. 93.-General view of portable band mill and set-up on an operation in Bertie County, North Carolina. Most of the lumber cut east of the Great Plains is produced from small sawmills cutting from 3000 to 10,000 board feet or more per day.

small souvenir boxes, and other articles, are sometimes made from small pieces of wood waste.

\section{FOREST PRODUCTS*}

1. General. In addition to lumber, the major product of the forest, may commodities and materials are secured from the forest. These products are exceedingly numerous and diversified. Most of them are derived from the woody trunk of the trees, which require felling, cross-cutting and perhaps further conversion in the woods. Other products are obtained from the sap or growing parts of the tree, such as maple syrup, rubber, and naval stores. These are secured without felling the tree and are obtained continuously over a period of years.

* For more extended treatment of this subject, see "Forest Products, Their Manufacture and Use," by Nelson C. Brown, John Wiley \& Sons, New York, second edition, 1927. 
Products classified according to their uses may be listed as follows:

1. Construction materials, such as lumber, timber, cross ties, poles, piling, posts, mine timbers, bridge planks, and shingles.

2. Chemical derivatives such as pulpwood, naval stores (turpentine and rosin), tannin, dyewood, hardwood and softwood distillation products, rubber, and maple sugar.

3. Wood containers, such as slack and tight cooperage, boxes and crating materials, and veneers, which are largely used as containers.

4. Miscellaneous products, such as fuelwood, which next to lumber is the most important product of the forest, excelsior, vehicle stock, cork, novelties, and toys.

Other classifications of forest products may be based upon methods of manufacture, that is, primary products of the forest which are not further refined or manufactured except in a crude way in the woods, for example, poles, piling, posts, hewed cross ties and timbers, mine props, and lagging. Manufactured products may include lumber, saw timbers, sawed cross ties, shingles, cooperage, veneers, or those further refined or remanufactured from lumber such as boxes and crating materials, some vehicle stock, including automobile body parts and planing mill products. Other products may be reduced chemically, as paper pulp, rayon or artificial silk, cellophane, hardwood and softwood distillation products, tanning materials, dyestuffs, and many miscellaneous derivatives obtained from the sap or wood, such as naval stores, rubber, and maple syrup. The volume of wood used for various products is generally expressed in terms of the individual commodity, such as board feet, cords, individual pieces, etc., as cross ties, poles, piling, or in cubic feet. For statistical purposes the government generally converts these materials into cubic feet, as indicated elsewhere.

Lumber is manufactured and sold for a great variety of purposes. The principal uses are as follows:

Percentage of Total Lumber Used for General Construction and Building Purposes

\section{ITEMS}

Millwork including sash, doors, trim and other planing

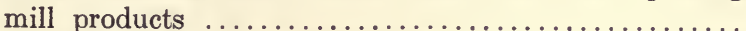

Remanufactured products as follows:

Boxes and crates $\ldots \ldots \ldots \ldots \ldots \ldots \ldots \ldots \ldots \ldots \ldots \ldots$

Railway car construction ...................... 3

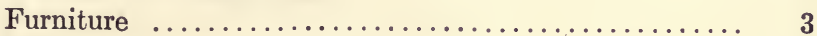

Vehicles .................................. 3

Miscellaneous forms manufactured from lumber ..... 6

Total $\ldots . . . \ldots \ldots \ldots \ldots \ldots \ldots \ldots \ldots, \overline{100}$ 
Lumber constitutes about one-half of all the materials cut in our forests annually. The balance is made up of the following:

ITEMS

Fuelwood

Hewed ties

Fence posts

Pulpwood

Mine timbers (round)

Veneer logs

Slack and tight cooperage .......................

Logs and bolts used in miscellaneous manufacture ......

Shingles

Miscellaneous, including export logs, poles, distillation wood, piling, tanning and extract wood, excelsior wood

Total of all forest products except lumber .......

Lumber

Total wood consumption
Percentage

27.6

4.4

4.3

4.1

100.0

The processes followed in producing some of these materials are briefly described as follows:

2. Cross Ties, Poles, Piling, and Mine Timbers. These are generally primary products of the forest. The tree is felled and cross-cut at selected intervals, the bark is removed, and hewed cross ties are faced on each side. They are produced in rough forms with little investment of capital for machines or equipment, other than axes, saws, bark spuds, tractors, or skidding teams and motor trucks. The primary features and requisites of these materials are durability and strength. Normally, nearly 100 million cross ties are produced in our woods annually. More than $90 \%$ of the cross ties used by the railroads are treated with some preservative material. This is also true of a large percentage of poles, piling, and mine timbers. The average untreated cross tie will only last about 5 years compared to 25 years for a treated tie. Many of these materials are obtained from farmers' woodlots and small tracts. The following table shows the principal species used for these materials:

Cross Ties

Poles

Oak (several species) Southern pine Southern pine

Douglas fir Ponderosa pine Lodgepole pine
Cedar (western red Douglas fir and northern and southern white)

\section{Douglas fir}

Chestnut

Lodgepole pine
Piling

Southern pine

Oak

Chestnut

Ponderosa pine
Mine Timber

Southern pine

Oak (several species)

Douglas fir

Chestnut

Maple 
3. Wood Pulp and Paper-Rayon and Fiber Boards. Approximately 7 million cords are annually used for the manufacture of pulp and paper. About 60 years ago the quantity of wood required for paper was insignificant. Now about $85 \%$ of all forms of paper are made from wood, although pulp may be produced from any fibrous material. Great advances have been made in the installation of pulp and paper mills in the South and on the Pacific Coast within recent years. Dr. Herty has succeeded in making newsprint from southern pine, but this method has not as yet been widely introduced or used on a commercial scale.

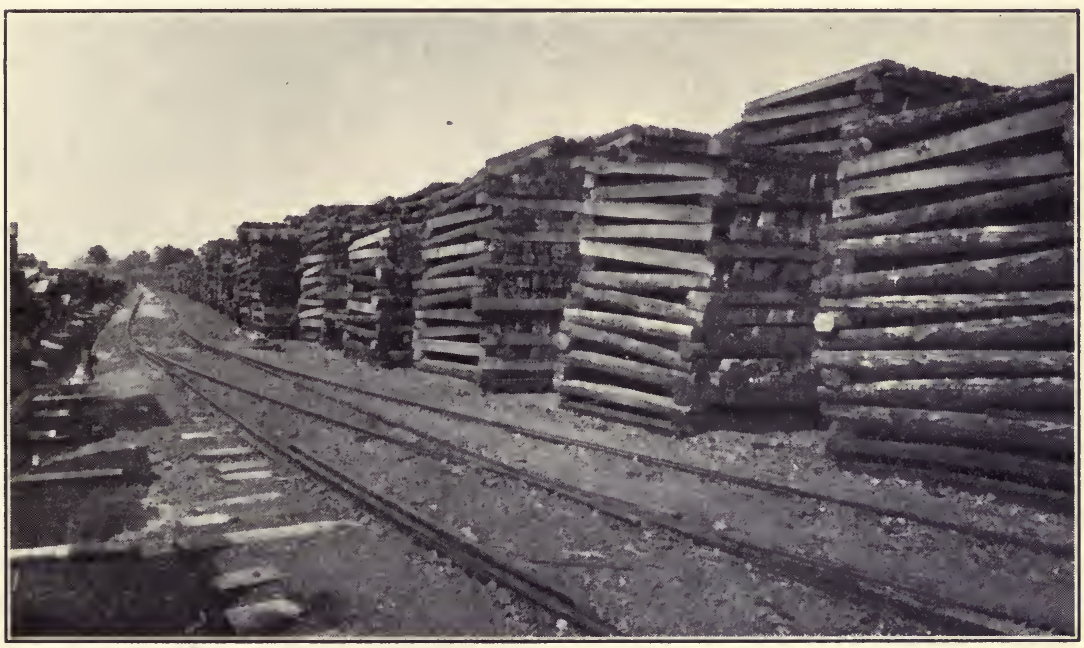

Fig. 94.-Seasoning oak cross ties before creosote treatment at preservation plant near Norfolk, Virginia. Note method of piling to provide proper circulation of air between ties during seasoning process.

The principal woods used for pulp are spruce, hemlock, poplar, southern pine, Douglas fir, and some of the hardwoods. Several hundred thousand cords of slabwood and other sawmill waste are converted into wood pulp every year. Sawmill and woods waste constitute almost the entire source of supply for the Pacific Coast pulp mills and an important part of the southern pine supply in the South.

The chief requirements for a good pulpwood are that it shall have long and strong and yet soft and tender fibers, the wood shall be relatively free from intercellular constituents, such as resins, gums, tannin, etc., the wood shall be available in sufficient quantities and therefore reasonably priced. White fibered woods are preferred; the wood should be sound and reasonably free from knots, rot, dote, pitch 
pockets, or other defects, and should contain large quantities of available cellulose.

The production of wood for pulp and paper is a most important industry in eastern Canada and constitutes one of the important industries throughout the Northeast, Lake States, and in several sections of the South and Pacific Northwest. The principal requirements for the location of pulpmills are:

1. A large initial investment, frequently from $\$ 200,000$ to $\$ 1,000$,000 or more.

2. A large and continuous supply of good and reasonably priced wood.

3. A plentiful and reliable source of clean water.

4. Adequate power to operate the machines in a pulp and paper mill.

5. Accessibility to a good fuel supply.

6. Adequate and inexpensive transportation facilities for the shipment of the products to market.

There are three methods of pulp manufacture as follows:

1. Groundwood pulp or mechanical pulp, in which the wood fibers are torn apart or reduced by mechanical abrasion. Spruce is best adapted to this method.

2. Sulphite method. This is the most important of the three chemical methods of wood reduction. The wood is generally cut into 2 -foot lengths, chipped to small sizes, and reduced to a pulpy mass in large digesters. The pulp is washed and screened and passed over a wet machine or press to form continuous sheets of pulp. The sulphite process is usually considered an acid process since the active pulping chemical is sulphurous acid and its calcium salt-calcium bisulphite -in aqueous solution.

3. Sulphate pulp. This is a more recent method of chemical reduction of wood fibers and is applied chiefly to southern pine as well as hemlock and some other species. Much sulphate pulp is imported from northern European countries to add to our local supplies. Much Kraft paper is produced in the South by this process. After chipping, the wood is digested under pressure in an alkali liquor containing sodium sulphide and caustic soda. These agents combine to reduce in the cooking process to form pulp which is run through press rolls and formed into bundles. Then after drying it is sent to the paper mill.

4. Soda Process. This is like the sulphate process-an alkali pulping method-but is applied chiefly to hardwoods, such as aspen, 
beech, birch, maple, yellow poplar, gums, and cottonwoods. The pulping liquor in this process is caustic soda.

Rayon. Large quantities of wood pulp are used in the manufacture of rayon or artificial silk. Sulphite pulp, since it requires less refinement and produces a higher yield than other wood pulps, is in greater demand. Most of the rayon is manufactured by the viscose process which is used also for the manufacture of cellophane. Other methods used for the production of rayon are the nitrocellulose, cellulose acetate, and cupro-ammonium processes. During a recent year over 157 million pounds of pulp were used for rayon and cellophane. Of this quantity, $60 \%$ was of wood pulp and $40 \%$ cotton linters. Production is concentrated largely along the Atlantic seaboard states.

Wood Fiber Insulating and Building Boards. An important application for sawmill and woods waste has developed within recent years. Enormous quantities of wood, formerly wasted, are now used for the manufacture of fiber boards. They must be made from chemical or mechanical pulp, originally derived from sawmill or woods waste in large part, or they may be made of other materials or combinations of wood and other materials such as asbestos, bagasse (sugar cane stalks after sugar has been compressed from them), cork, cornstalks, licorice roots, moss, gypsum, and several others.

The principal types may be:

1. Rigid, combining both insulating and strength properties.

2. Semi-rigid, such as felts, which are somewhat flexible.

3. Flexible, consisting of loose fibers and covered with paper or fabric.

4. Filler, made of powdered, shredded, or granulated material.

The advantages and reasons for the wide introduction and increased use of insulating boards and materials are:

1. They lower fuel costs by preventing undue loss of heat.

2. Smaller and more economical heating systems are necessary.

3. Greater comfort is provided during both winter and summer.

4. They are necessary for air conditioning.

5. Fire hazard is reduced.

4. Fuelwood furnishes fuel for a great variety of industrial and domestic uses. For many years prior to the introduction and use of coal, fuel oil, and natural gas, it was the only fuel available. The threat of a fuel famine was the chief reason for the establishment of forestry in Europe. Formerly fuel was the chief use of forest products in this country. Within recent years, it has rapidly' decreased in importance because of the competition from coal and other fuels. It 
now constitutes the second most important use of our forests and is next to lumber in volume. Large quantities are still used on our farms, where the average family consumption is about 17 cords per annum. In the rural districts of the South, East, and Lake States, wood is the chief fuel. In the Pacific Northwest, hogged fuelwood from sawmill waste is widely used in domestic furnaces as well as for furnishing industrial heat and power. Fuel value is directly related to specific gravity. The resinous woods like the pines and Douglas fir have higher heating values than non-resinous woods, provided they have the same specific gravity. The most valuable woods for fuel in order of importance are hickory, oak, beech, birch, maple, ash, and elm. The most valuable softwoods in order of importance are tamarack, longleaf pine, Douglas fir, other southern pines, lodgepole pine, and white pine.

Under favorable circumstances, one man can fell, chop, and stack one cord of wood per day. Recently, gasoline engines generally furnished in a tractor have been commonly employed to buck up limbs, tops, and defective wood into cordwood. The slabs, edgings, and trimmings of most of the small mills, and of many of the large mills, are used for fuel, either for domestic or industrial purposes. For domestic purposes fuelwood is generally cut into 12- to 18-inch lengths. Much 4-foot fuel is used in domestic furnaces in the Northwest.

5. Veneers and Plywood. The use of wood in manufacture of veneers has advanced strikingly during recent years compared to the general use of wood. The principal veneer woods are Douglas fir, red gum, southern pine, and ponderosa pine; they find extensive application for shipping containers and for built-up stock or plywood for doors, panels, furniture parts, drawer bottoms, and automobile parts. Plywood is used for shipping containers in place of the former solid boards, paper, or fiber boards. The use of wood for veneers and plywood has doubled in 10 years. In addition to the species mentioned, ash, birch, oak, maple, elm, basswood, black walnut and many other species are valuable for this purpose.

Veneers are made by three processes:

1. Rotary method, that is by turning a bolt or large log of wood against a knife, thus cutting continuous sheets of wood as shown in the illustration.

2. The slicing method by which sharp knives are sent against a stationary flitch, and

3. Sawed veneer. 
The first method is the most common. The other two methods are used only with the most valuable species, such as mahogany, Circassian walnut, black walnut, and other high-grade cabinet woods.

Veneers are generally cut from $1 / 8$ to $1 / 20$ inch in thickness. Careful methods of drying must be used after manufacturing, especially in connection with rotary-cut veneers, in which the wood is steamed, or immersed in hot water prior to cutting.

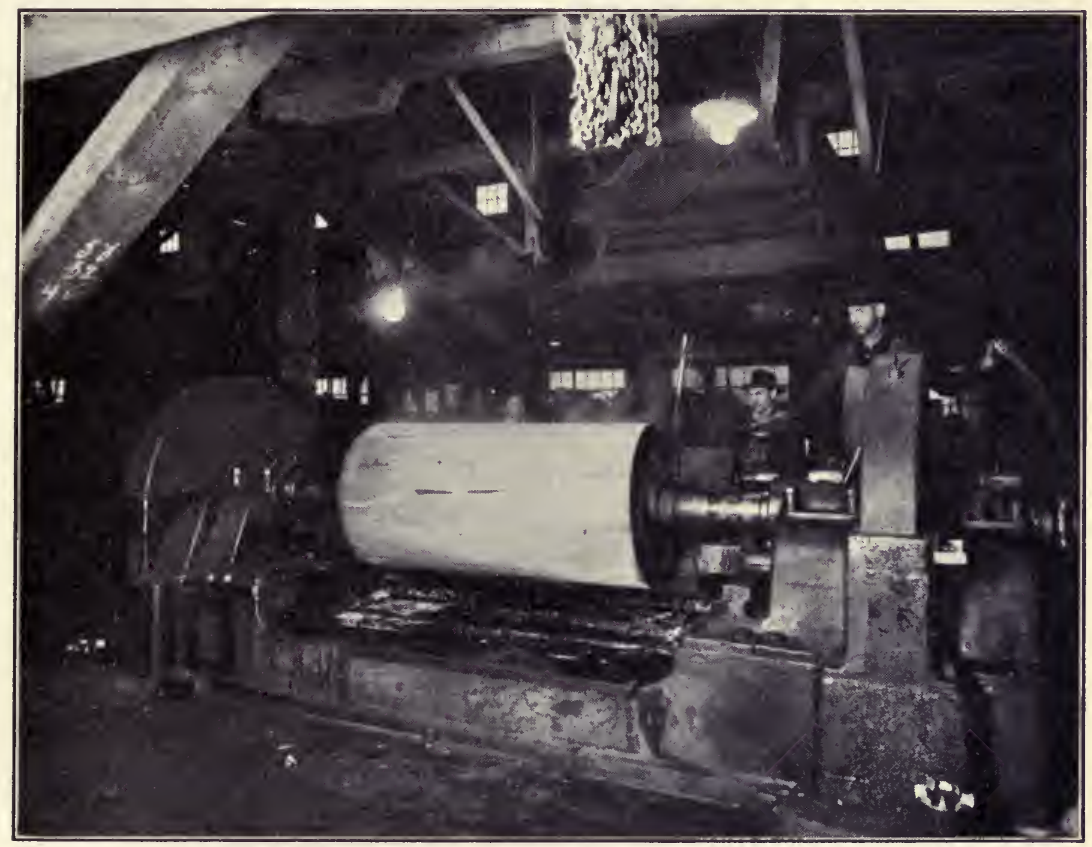

Fig. 95.-Lathe used in making rotary cut veneers. Much Douglas fir, southern and ponderosa pines are cut into rotary veneers by this method. The veneer log is slowly turned against a sharp knife which cuts thin sheets of wood of the desired thickness.

6. Naval Stores. Resin is obtained from the resin ducts in longleaf and slash pines. The other two southern pines, loblolly and shortleaf, do not yield a sufficient flow of resin for commercial purposes. The face of the tree is chipped weekly or at regular intervals to stimulate the flow.

Naval stores is one of the oldest industries in the country and is now centered in Georgia, Florida, and Alabama in order of importance. Savannah is the great market for naval stores, and secondgrowth timber constitutes practically the entire source of supply. The primary products of the earlier years of the industry were pitch and 
tar, which were among the first exports from this country and extensively used in wooden sailing vessels-hence the name naval stores.

The gummy exudation from the trees is known as resin or crude turpentine. This is distilled into turpentine or spirits of turpentine, the residue after distillation forming the rosin of commerce. The peak of production was reached several years ago when over 38 mil-

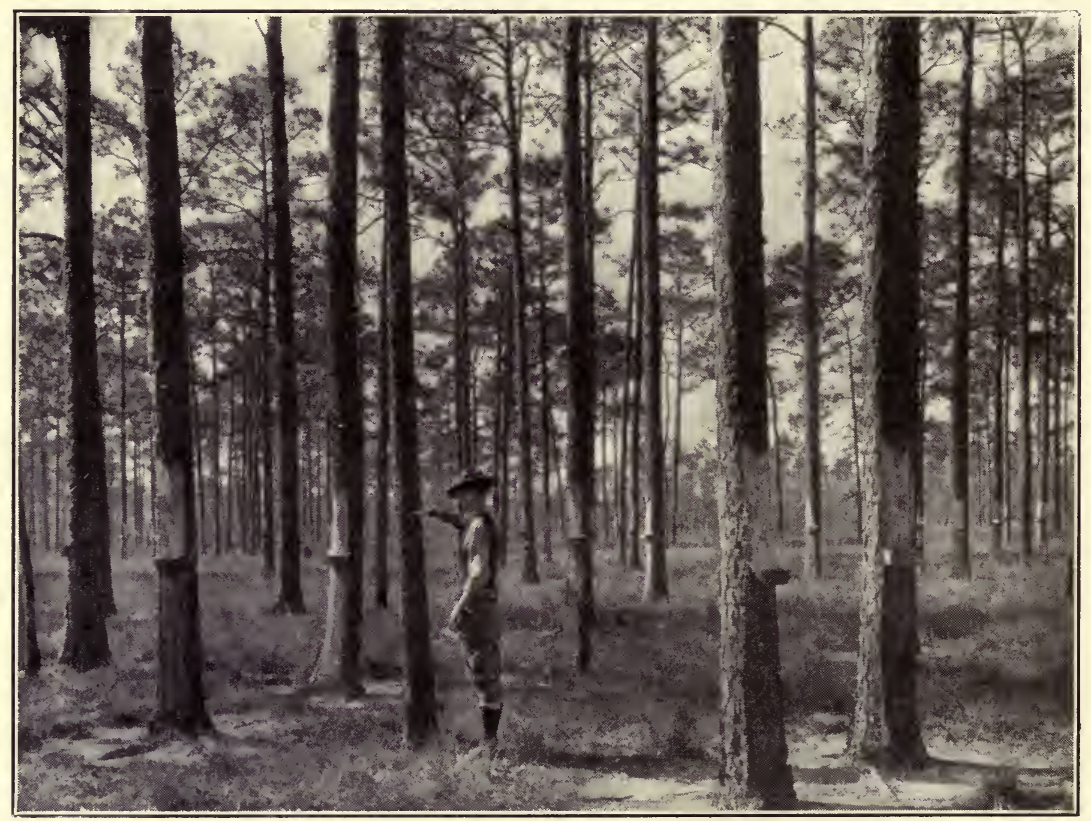

Fig. 96.-Turpentining operations, fifth year's work. Many improvements have marked the naval stores industry in recent years, especially in more shallow and narrow faces in tapping the longleaf and slash pines. Georgia is the center of the naval stores industry and second growth timber is the chief source of supply. Conservative chipping costs no more, yields 20 to $50 \%$ more gum per face and the yield may continue for 8 years. Tacking the tin gutters instead of inserting them increases the yield 15 to $20 \%$ or more over a 5 year period.

lion gallons of turpentine and 4288 thousand barrels of rosin were marketed in one year.

Formerly a box formed by shaping a cavity near the base of the tree about 3 to 4 inches wide, 6 to 7 inches deep, and 10 to 12 inches long was used to collect the resin. This was found to be very wasteful. Now cups or metal containers are used to collect the resin and are moved up the tree as the face is chipped. Chipping consists of re-exposing the cambium layer by cutting it periodically with a 
chipper or hack. This chipping is generally done once a week during the warm season from March to October. Many studies have been made to improve the method of chipping and collecting the resin. Turpentining is generally conducted in units known as crops which consist of a turpentine orchard of 10,500 faces. There may be one, two, or three faces on each tree, depending upon its surface. No tree smaller than $9^{\prime \prime}$ d.b.h. should be tapped for turpentine.

7. Cooperage. Cooperage is made from wood in three forms, namely: staves, heading, and hoops. Tight cooperage refers to barrels and kegs which contain liquid materials. Slack cooperage is used for shipment of flour, sugar, lard, paint, meat, fish, vegetables, fruit, hardware, crockery, and rosin. Since the repeal of the prohibition amendment, the demand for tight cooperage stock has advanced very materially. White oak is the principal wood used for tight cooperage. For slack cooperage a great variety of inexpensive woods are used, chiefly red gum, beech, birch, maple, tupelo, and southern pines. Southern pine and white pine are preferred for heading. Elm is the principal wood used for hoops.

8. Tanning Materials and Dyewoods. These are compounds found in various woody plants. Tannins are found chiefly in the bark and leaves of some species, the chief sources being hemlock and oak bark, chestnut wood, and sumac leaves and twigs. Imported sources of tannins are quebracho from South America; wattlewood from Australia, myrobalan nuts from India, and mangrove bark from the East India tropics. Tannin possesses the property of precipitating gelatine soluble proteins and alkaloids from solutions which, combined with the skinned protein of animals, forms a durable, flexible, impervious product known as leather. Formerly, natural vegetable dyestuffs formed the principal sources of dye materials. Synthetic or coal-tar dyes now dominate the market. The more important natural dyestuffs are logwood from Central America, brazil woods imported from the West Indies, brazil of the Bahamas, which yields hypernic and braziline, fustic from the West Indies and Tropical America for yellow dyes, and osage orange from the Southwest used in dyeing cotton, leathers, wood, and paper.

9. Wood Distillation. By the process of destructive distillation, wood yields three primary products, namely non-condensible gas, pyroligneous acid, and charcoal. In distilling the wood of southern yellow pine, turpentine, rosin, and pine oils are obtained. Pyroligneous acid is distilled to produce wood alcohol or methanol as well as acetone, acetic acid, and wood tar together with other, less im- 
portant products. The principal hardwoods distilled for these products are beech, birch, maple, and hickory. Hard, heavy woods are preferred. Steam distillation and solvent extraction methods are also used with southern pine chiefly for the recovery of rosin, pine oils, and turpentine.

The larger volume of wood is utilized by the hardwood distillation process, by which cordwood in 4- or 5-foot lengths is thoroughly seasoned for one year or more, then placed on buggies and moved into ovens 52 feet or more in length, about 8 feet in height, and 6 feet wide. After closing the doors, the ovens are heated underneath to temperatures of $450^{\circ}$ to $600^{\circ} \mathrm{F}$. for about 24 hours. The gases from this heating process are condensed and form pyroligneous acid, the residue remaining as charcoal.

This industry has been able to survive after keen competition from synthetic alcohol and acetate products only through research and the application of new practices. Waste gases from the distillation are now used to furnish heat by which the wood is rapidly seasoned, thus making a long air-seasoning period unnecessary. Wood is cut into small pieces, making mechanical handling possible, and in the Stafford process the ovens are insulated so that heat lost during the exothermic reaction may be used to bring the temperature of new wood up to the carbonization point. This is therefore a continuous process using finely divided wood, and it promises to offer a method whereby large quantities of sawmill waste in form of dust and slabs may be utilized.

10. Maple Syrup and Sugar. Throughout the Northeast and the Lake States the sap is collected from the sugar maple during the early spring season. The industry is centered in Vermont, New York, Ohio, Pennsylvania, and Michigan. From one to four or more buckets are attached to spouts inserted in auger holes $7 / 16$ inch in diameter. About 45 million pounds of maple sugar have been made annually in this country. Individual trees may yield from 1 to 7 pounds of sugar. From a standard sugar bush of 500 buckets there is an average yield of about 6400 gallons of sap. This is equivalent to about 200 gallons of maple syrup or 1500 pounds of sugar. Ordinarily it requires 32 gallons of sap to make a gallon of syrup, and $4 \frac{1}{4}$ gallons of sap are required for a pound of sugar. An average of about 12.8 gallons of sap is secured from each bucket in the average sugar bush. A gallon of good syrup will yield about $7 \frac{1}{2}$ pounds of sugar. Many forests are managed in the northern New England States as well as in New York and Ohio for the production of maple syrup and sugar and at the same time cattle are permitted to graze in them. The graz- 
ing should be discontinued if the young growth is to be encouraged and the sugar bush properly maintained.

11. Rubber. Crude rubber or latex is obtained by scarring the trunk of the rubber tree, the Hevea braziliensis, a native of the Amazon River region of South America. Many plantations of this tree have been made in Malaya, Sumatra, Java, Ceylon, Burma, in the East Indies, and Liberia in western Africa, by British, Dutch, and American rubber companies. Trees are tapped for latex daily, except during February and March when the leaves are shed. The enormous consumption of rubber for tires and many other articles has caused many companies to invest large sums of money to establish plantations to assure the continued and reasonably priced supply. Great advances have marked the planting of rubber trees together with the collection of latex and its manufacture into rubber.

\section{TRENDS TOWARD STABILITY OF LOCATION, EMPLOYMENT AND OUTPUT}

Until recently, the American lumber industry has been notable for its nomadic and migratory characteristics. Lumber production has been largely from the immensely large sawmills. For many years, the practice of "cutting out and getting out" has been followed.

Within recent years there have been marked tendencies in the direction of greater stability of location employment and output. These trends are primarily due to:

1. The change from the large to the small sawmill unit. Probably 70 to $80 \%$ of all the lumber produced east of the Rocky Mountains now comes from the small sawmill cutting generally 5000 to 15,000 b.f. or less per day.

2. The improved highways and better motor-car design and manufacture have resulted in motor-truck transportation of logs for long distances to the sawmills rather than moving the sawmill to the woods, as has been done with small sawmills until recent years.

3. The rapid growth of timber in most of the regions, especially in the South and Southeast, making possible a permanent supply of logs tributary to the stable locations. Frequently the small sawmill is the principal local industry. Community life, income (wages and employment), banking, and trade revolve around these small mills together with the moving of lumber from mills to market and the transportation of logs to mills.

4. The encouragement and construction of small forest industries on a permanent basis. The management plans of some National 
Forests, like the White Mountains in New Hampshire and Maine, are based upon the supply of the timber from given drainage units to small hardwood, bobbin, shoe heel, woodworking, toy, wooden box, furniture, or other small plants that consume the growth of the areas naturally tributary to them.

As pointed out elsewhere, several million people are dependent upon the forest for employment. The preponderant share of the wages for this employment is in the logging, manufacturing, and distribution phases of the forest industries. If timber is being grown continuously and made available to these industries regularly, they in turn will be consistently supplied and maintained. This is the very essence of good forestry and of sustained yield management. 


\section{CHAPTER XIII}

\section{FOREST UTILIZATION-TIMBER PRESERVATION}

\section{HISTORY AND IMPORTANCE}

From the earliest days of civilization several methods have been employed to extend the life of wood in service. In ancient Roman and Greek times wood was charred or painted to prevent decay under exposure. The preservative treatment of timber has been actively practiced in Europe for over 100 years, and practically all cross ties, telephone and telegraph poles, posts, grape stakes, and many other materials exposed to decay are treated with some preservative.

In the United States timber preservation has made rapid strides since 1900. The first plant was established in 1873 at Pascagoula, Mississippi, on the Louisville and Nashville railroad. In 1904 there were 33 plants with an annual capacity of 250,000 b.f. of material. In 1933 there were 210 plants in existence, of which 187 were active and producing $1,500,000,000 \mathrm{~b}$.f of material. Many hundred million dollars are invested in small and large treating plants to increase the life of various forms of wood in service, particularly cross ties, poles, and lumber that may be subjected to conditions of decay.

Timber preservatives provide a means of more intensely utilizing the products of the forest. In increasing the life of timber by an inexpensive method of preservation a great service is rendered the consumer and our forest resources are conserved.

Authorities estimate that the annual loss of wood due to decay amounts to more than 7 million b.f., or over $70 \%$ of all the cost of wood destruction. Some of our most durable species such as cypress, black locust, white oak, and cedar are not available for many inexpensive forms of construction. Less durable woods, some of the pines, Douglas fir, and many of the hardwoods may be made to serve many useful purposes when treated with preservatives.

\section{MATERIALS TREATED}

The principal materials and the quantity of each treated are as follows: 
CoMmodiTy

Cross ties

Switch ties

Poles

Cross arms

Paving blocks

Constructions timbers

Miscellaneous material
Cubic Feet Treated, 1933 $68,089,695$

$5,430,278$

$30,120,834$

313,440

388,537

$12,156,752$

$3,219,326$

All timbers used for bridges, mines, jetties, wharves, mill construction, foundations, and other forms of exterior construction should be treated to increase the length of service.

Approximately $90 \%$ of all cross ties and $80 \%$ of all poles purchased are treated with preservatives.

\section{REQUIREMENTS OF A GOOD PRESERVATIVE}

The requirements of a good and effective preservative are as follows:

1. Available in large quantities, and therefore reasonably inexpensive.

2. Toxic or poisonous to wood-decaying fungi.

3. Must not readily evaporate or leach out of the wood.

4. It must not affect the strength of timber in service.

Creosote fulfils these purposes as the best medium. Zinc chloride is also widely used in arid regions where it is not likely to leach out of the wood. Painting also serves as a good superficial treatment. Copper sulphate, mercuric chloride, and several patent chemicals have also been used. Creosote oil is the product of the distillation of either coal, wood, or water-gas tars.

\section{PRINCIPAL METHODS OF PRESERVATION}

The principal methods used in timber preservation are:

1. Pressure or cylinder process.

2. Open tank method.

3. Brush or spray treatment.

4. Dipping process.

Cross ties, cross arms, poles, piling, and many posts as well as structural timbers are generally treated by the pressure method. This means the impregnation of the wood by forcing creosote or other chemical preservative into the wood under high pressure. This is accomplished generally in large, long cylinders. The materials to be treated are loaded on cars and hauled directly into the cylinder, which may be from 50 to 175 feet or more in length and from 4 to $91 / 2$ feet in diameter. Various forms of the pressure treatment are the Bethel, 
Rueping, Lowry, and Card processes.* Sometimes the materials are thoroughly seasoned prior to treatment. In some methods live steam is introduced into the cylinder and a pressure of 20 pounds per square inch maintained for several hours, and followed by a vacuum period. The wood is then seasoned or conditioned and has a greater capacity for absorbing preservatives. Steaming softens the fibers and opens the pores of the wood. After various forms of preliminary treatment, the creosote, zinc chloride, or other preservative is run into the cylinder at definite temperatures. Pressure is then forced upon the preservative so as to drive the fluid into the wood fibers. The amount injected depends upon the species, condition, character, and size of the materials and. the amount desired in the wood. After this pressure is released a vacuum is sometimes applied to draw out the excessive fluid and hasten the drying process.

The open-tank method is used with fence posts, grape stakes, highway posts, and for the treatment of chestnut and cedar poles. After the bark is removed and the wood entirely seasoned, the posts or poles are immersed in a hot bath of creosote of temperature not exceeding $215^{\circ} \mathrm{F}$. This heating process continues for 2 to 6 hours, depending upon the

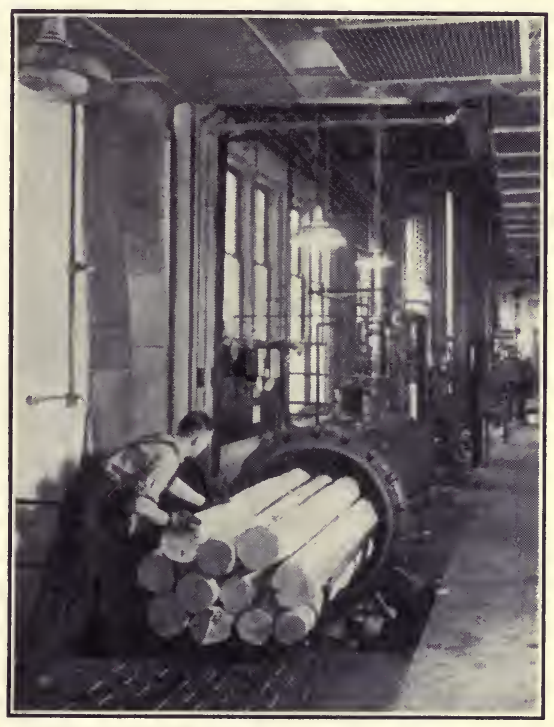

Fra. 97.-Moving poles into a small experimental cylinder preliminary to preservative treatment by pressure process to increase the length of life in service. Photo taken at U. S. Forest Products Laboratory at Madison, Wisconsin.

species, size, and condition of the material. During the heating the moisture and air expand and a large portion passes out, appearing as steam or air bubbles at the surface. The posts and poles are then quickly removed to a cold bath of creosote. The contraction of the air and moisture in the wood due to the changing temperatures creates a partial vacuum which is destroyed by the entrance of the preservative fluid. In this manner atmospheric pressure due to quick changes in temperature accomplish the impregnation of the wood at least to a partial degree. Sapwood is much more readily subjected to

* For further information regarding these processes, see Annual Proceedings of the American Wood Preservers' Association, Washington, D. C. 
treatment, and therefore thorough penetration is obtained on posts and poles where the preservative is most needed. Open-tank treatment is conducted in a very simple and inexpensive manner. Old tanks, metal barrels, or other containers are used for the process. Fires are built underneath them to heat the creosote to the proper temperature and nearby containers are used in which the posts and poles are plunged.

Brush or spray treatment consists of using creosote, paint, or other

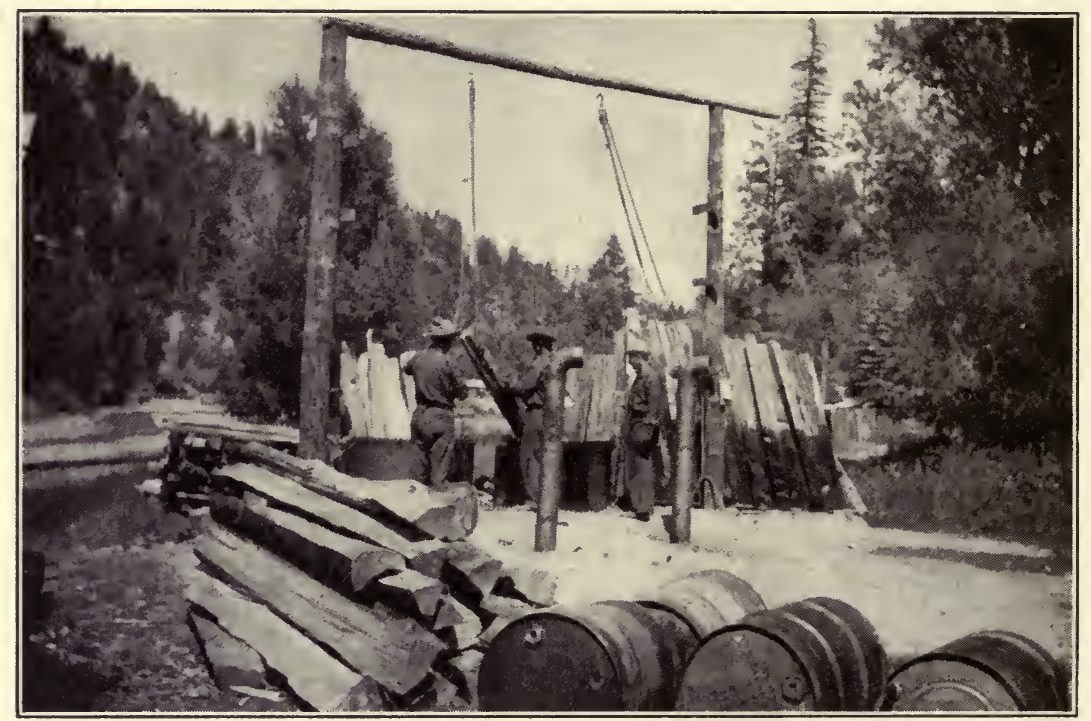

Fig. 98.-Many thousands of fence posts are annually treated with creosote to increase their length of life in service. This treating plant is on the San Juan National Forest, Colorado. Many miles of drift fences are built to control grazing on the National Forests.

materials to treat the wood superficially. This method is used with poles, posts, shingles, timbers, and many other forest products. Many patented preservatives are on the market for use in connection with the brush or spray treatment. Although not so effective as the pressure or open-tank methods of treatment, satisfactory results are often obtained by this means. All the cracks and checks are completely filled or covered with the fluid. Knot holes or similar defects offer the best opening for wood-destroying fungi. All wood should be thoroughly air seasoned before brush or spray treatment. Dipping is another method of treatment and sometimes yields satisfactory results with piles, caps, and other timber as well as with shingles, posts, and some poles. 


\section{PART III}

\section{ORGANIZATIONS AND AGENCIES TO ACCOMPLISH A RATIONAL FOREST POLICY}

The organizations seeking to accomplish the practice of better forestry in this country may be classified as public and private. The public agencies are the federal, state, county, and municipal units.

Many federal departments, agencies, and bureaus are engaged in or concerned with the development of forestry policies. Among the more important are the following:

1. In the Department of Agriculture-the Forest Service, the Soil Conservation Service, the Biological Survey, and the Bureau of Plant Industry.

2. In the Department of the Interior-the National Park Service, the Indian Service (for Indian forests), and the General Land Office (relating to the public domain).

Other federal activities partly concerned with some phases of forestry are the Forest Products Division of the Bureau of Foreign and Domestic Commerce, Bureau of Fisheries, Bureau of Standards, and Census Bureau in the Department of Commerce; the Internal Revenue Bureau of the Treasury Department; and separate agencies, such as the Federal Trade Commission, Smithsonian Institution, and the Tariff Commission (relating to import duties on forest products).

Since the inauguration of President Roosevelt in 1933, several new governmental agencies which have great significance in the development of forestry policies have been established. Among those described later are the following:

1. Emergency Conservation Work (Civilian Conservation Crops).

2. National Recovery Administration (relating to lumber code).*

3. Tennessee Valley Authority.

4. Soil Conservation Service.

5. Plains Shelterbelt Project.

6. Public Domain Grazing Administration.

* See Appendix. 


\section{CHAPTER XIV}

\section{THE FOREST SERVICE AND THE NATIONAL FORESTS}

\section{HISTORY AND DEVELOPMENT}

Prior to 1891 when Congress authorized the President to set aside forest reserves which later became known as National Forests, the public domain or national property belonging to the government throughout the West was given practically no protection, care, or

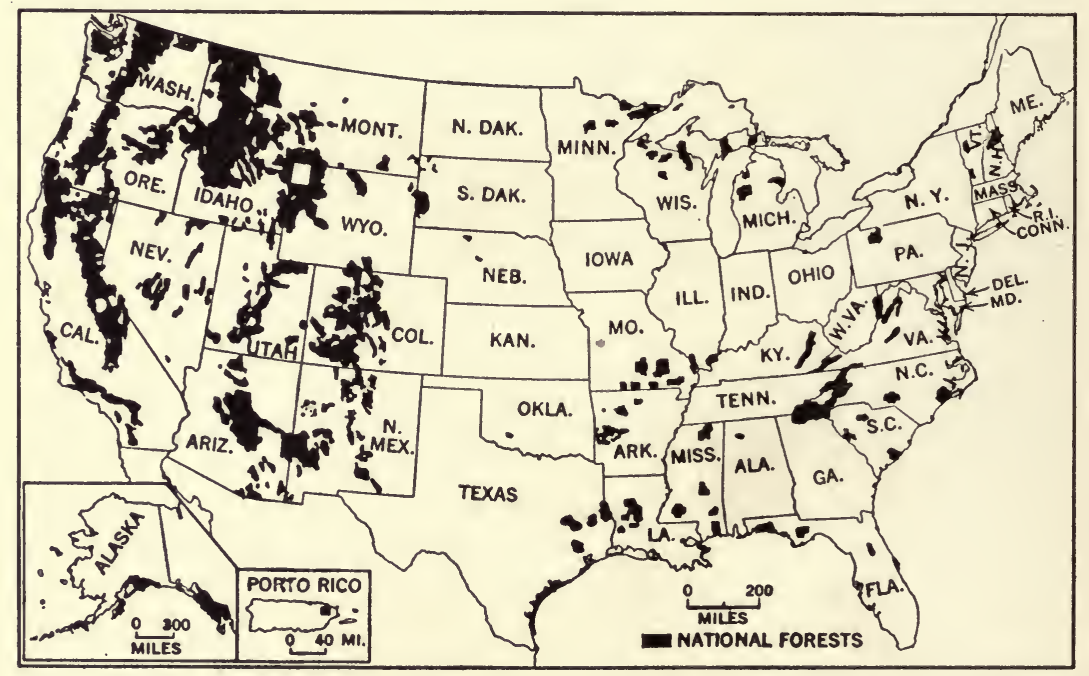

Fig. 99.-Map showing location of the National Forests. There are approximately 170 million acres of National Forests equivalent to over five times the total area of Pennsylvania.

management. It was being recklessly burned, and much timber and other resources were being illegally taken from it. As there was no organization to protect it, the people generally regarded government property as belonging to no one in particular and therefore available for private use and exploitation.

It was not until 1897, in fact, that provision was made in the Division of Forestry for the administration of forest reserves that 190 
were withdrawn from entry or alienation. It became the duty of the Secretary of the Interior to make regulations for the fulfilment of the objectives set forth in creating these reserves. Provision had to be made for the growing of continuous forest crops. Unrestricted grazing had for many years seriously injured or destroyed the range. A new organization was set up to combat or suppress forest fires. The forestry work of the government was transferred to the Agricultural Department in 1905 when the Bureau of Forestry became the Forest Service. Later, in 1907, the title of forest reserves was changed to National Forests to indicate that these resources are for the benefit

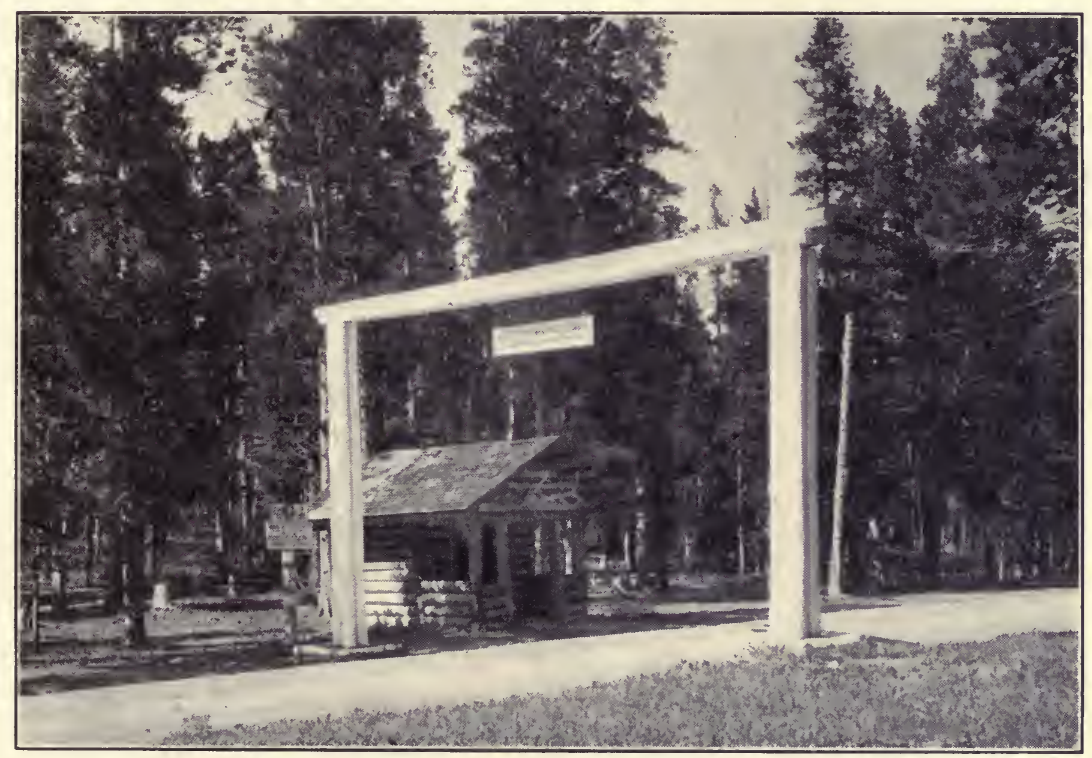

Fig. 100.-Portal at King's Hill Pass, Lewis and Clark National Forest, Montana.

and use of the people of the country and are not to be stored up or reserved for the future without thought of current use.

Until 1908, all the forestry work of the Federal Government was centralized in Washington. With the area of National Forests rapidly increasing above 100 million acres, it became necessary to set up a much larger organization and to decentralize the work out of Washington. Local administration was found to be much more effective and in more intimate relationship with the local and regional requirements.

As the National Forests were largely located in the West, local districts now known as regions were established there; those in the 
East and South came later. The present regions, with regional offices, are as follows:

Region Regional Headquarters

1. Missoula, Montana

2. Denver, Colorado

3. Albuquerque, New Mexico

4. Ogden, Utah

5. San Francisco, California

6. Portland, Oregon

7. Washington, D. C.

8. Atlanta, Georgia

9. Milwaukee, Wisconsin

10. Juneau, Alaska

\section{States of Each Region}

Montana, northern Idaho, northwestern South Dakota, and northeastern Washington

Colorado, most of Wyoming, southwestern South Dakota, western Oklahoma, and Nebraska

New Mexico and Arizona below the Colorado River

Utah, Nevada, southern Idaho, northern Arizona, and western Wyoming

California and part of western Nevada

Washington (except for northeastern corner) and Oregon

The northeastern region, including Virginia and Kentucky

South and southeastern region from North Carolina to Texas, Arkansas, and western Oklahoma inclusive

The Lake States and Central States, including Ohio, Indiana, Illinois, Missouri, and Iowa Southeastern Alaska

Under the Weeks Law of 1911, provision was made for the purchase of National Forests in the East. This continued until 1933 when President Franklin D. Roosevelt set aside 20 million dollars for additional purchases, and in 1934, 10 million dollars more, making a total of 30 million dollars for greatly expanding the eastern and southern National Forest areas. A separate region was established for the South with headquarters at Atlanta, Georgia, in 1934.

The following have been the chief foresters in the Federal Service with periods of incumbency:

NAME

Franklin B. Hough

Nathaniel Eggleston

Bernhard E. Fernow

Gifford Pinchot

Henry S. Graves

William B. Greeley

Robert Y. Stuart

Ferdinand A. Silcox
Dates

1877-1883

1883-1886

1886-1898

1898-1910

1910-1920

1920-1928

1928-1933

1933- 


\section{EXTENT AND LOCATION OF NATIONAL FORESTS}

The National Forests and the purchase units cover a total net area of about 170 million acres. They include about 134 million acres in the so-called public land states west of the Mississippi River (located principally in the Rocky Mountains, Sierra Nevada, and the Cascade ranges in the West), more than 14 million acres in the eastern, southern and Lake States, and over 21 million acres in Alaska. There are some 20 million acres of private or alienated holdings within the exterior boundaries of these National Forests, making the total gross area of our National Forests about 190 million acres. Through purchase and land exchanges these areas are being consolidated so that solid blocks may be provided for the purpose of more efficient management and protection.

This vast area is more than 5 times the area of the State of Pennsylvania and includes about 600 billion board feet of standing timber of merchantable size. It is divided into approximately 150 National Forests, averaging somewhat over a million acres each. This is done for administrative purposes. A million acres is an area approximately 40 by 40 miles square in extent, or about 1600 square miles.

\section{ORGANIZATION OF THE FOREST SERVICE}

The administration of the Forest Service is centered at Washington, D. C., under the Forester, where the work is divided into the following principal branches:

1. Finance and accounts.

2. Operations (fire control, personnel, supplies and equipment, etc.).

3. Forest management (timber sales and surveys, planting, pest control, etc.).

4. Range management (reconnaisance and inspection).

5. Lands (acquisition, exchange, records, claims, and uses).

6. Engineering (roads, trails, waterpower, bridges, maps, and surveys).

7. Public relations (cooperation with states and private owners, information and education).

8. Research-with divisions of silvics, range research, forest products and forest economics, and with general charge of the experiment stations and the U. S. Forest Products Laboratory at Madison, Wisconsin. 
In each of the regional headquarters noted previously, the work is divided similarly to that at the Washington office except that research is administered directly from Washington rather than from the regional offices, as at Missoula, Montana; there is a separate law branch for each region to handle legal matters and law enforcement.

The U. S. Forest Service is divided for organization purposes into three principal divisions or activities, namely: (a) the protection,

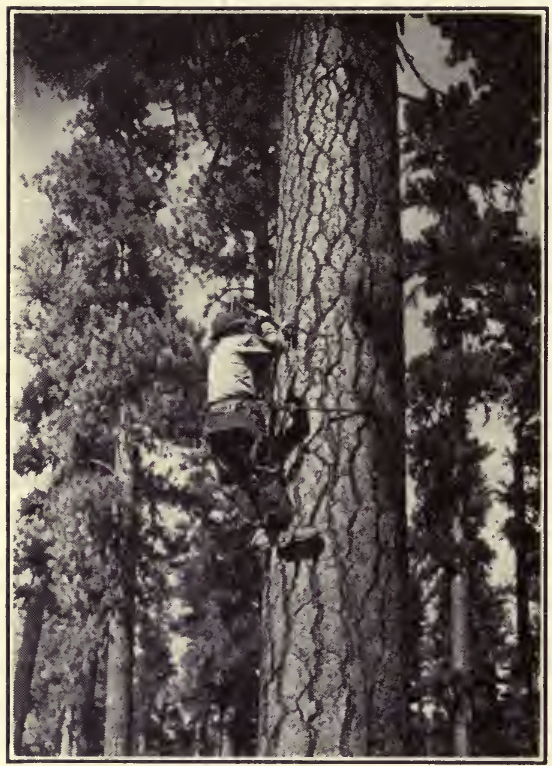

Fig. 101--Hanging an insulator on a tree in constructing a telephone line in the Fremont National Forest in Oregon. The construction of telephone lines is an important part of forest protection as well as of forest administration. administration, and development of the National Forests; (b) research and technical investigations to improve the growing conditions and more efficient utilization of our forests, particularly on federal properties; $(c)$ extension work, known also as public relations, including cooperation with the various State Forest services and private owners in promoting better forestry practice in the woods.

The permanent force of the Forest Service includes about 3000 men, of whom two-thirds are employed in the National Forests as supervisors, assistant supervisors, rangers, lumbermen, junior foresters, and other technical assistants. The remainder are engaged in administrative, scientific, and clerical work at the Washington and regional offices, as well as at the Forest Products Laboratory at Madison, Wisconsin, and the forest and range experiment stations. In addition to the permanent force, more than 3400 temporary guards are employed on National Forests during the hazardous fire season.

\section{Protection and Administration of National Forests. Protection} from injurious agencies. The most important work of the National Forests, both in time and in significance, is that of protecting the forests from fire, insects, and disease. This is of fundamental and outstanding value because if the future of the forest is not assured there is little need of other administrative work. The growing use of 
the forests by the public has increased the hazards from fire, but in spite of this fact less than $0.1 \%$ of the total area within the National Forest boundaries is annually burned. There are three reasons for this excellent record, namely: (1) the improved efficiency of the trained, permanent organization in all details and phases of fire prevention and suppression; (2) the increase during recent years in mileage of protection roads and trails making quick ingress of fire-fighting equipment and men to combat fires; and (3) the great help offered by

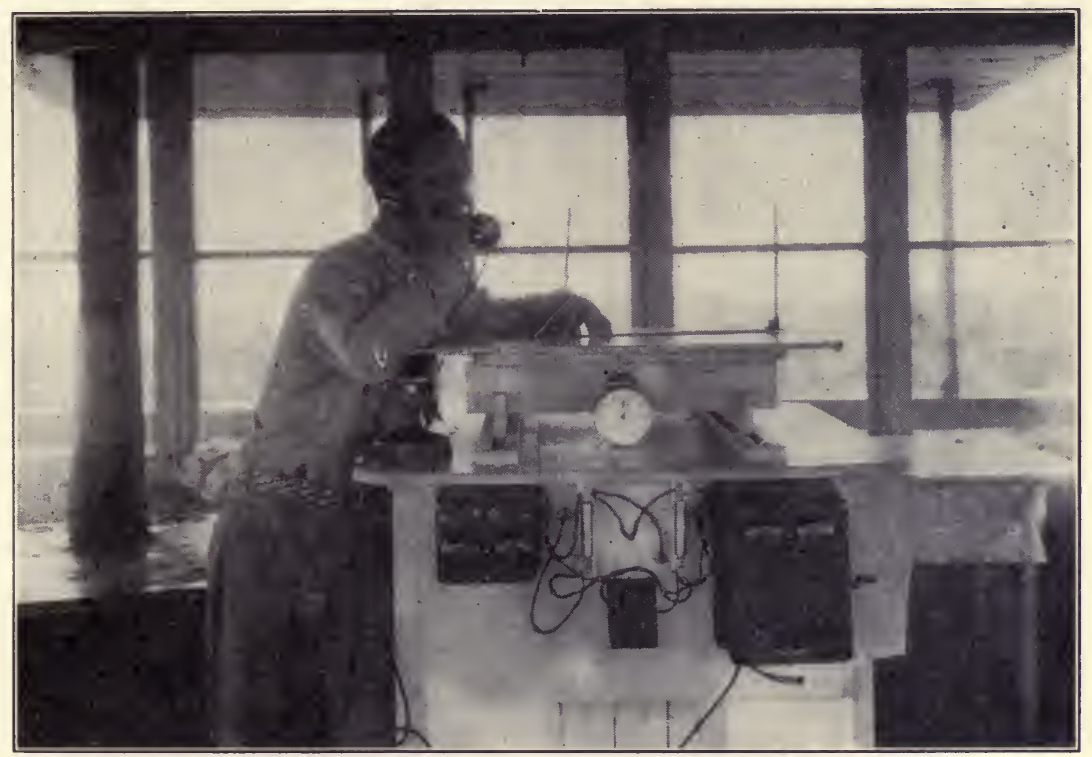

Fig. 102.-Observer reporting fire at Oak Mountain Lookout station, Ouachita National Forest, Arkansas. The Osborne fire finder is widely used to determine the location of a fire after the observer sights it through the instrument on the topographic map in the lookout station.

the men of the Civilian Conservation Corps, in reducing fire hazards, in actual fire suppression, and in providing a large body of young men quickly available in case fires are started.

Records show that of all the causes of forest fires in National Forests, lightning causes about $41 \%$, careless smokers $21 \%$, incendiarism $15 \%$, camp fires left unextinguished $10 \%$; and the balance is attributed to débris burning, railroads, lumbering, and miscellaneous causes. Areas of very serious fire hazard exist in the Inland Empire of northern Idaho and western Montana and in southern California. A deficiency of precipitation resulting in insufficiently fire-resistant 
forest cover has caused serious fires, which, coupled with floods, has inflicted great damage and property losses. The white pine blister rust and the western pine bark beetles on both ponderosa and lodge-

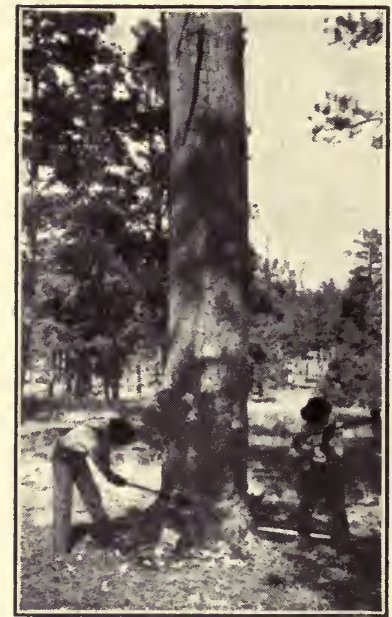

Fig. 103.-Chopping the undercut on a tree marked for cutting in a National Forest area in Arizona. The open character of the timber and the generally level topography make logging a relatively simple problem in most of the ponderosa pine forests except in California where the large size of the trees and frequently rugged topography make logging a difficult problem. Selective logging is widely practiced on our National Forests. Trees are generally marked prior to felling. pole pines have caused considerable losses and required the services of large numbers of men.

Timber Growing and Cutting. One of the most important phases of the National Forest activities is the growing and cutting of timber through a system of timber sales. The best silvicultural and utilization practices are usually followed. Normally about 1 billion board feet of timber is cut each year, the peak being $1,600,000$,000 in 1930. There were over 16,000 small timber sales, each involving $\$ 500$ or less, and 129 sales of over $\$ 500$. Much timber is given away to local settlers. Through the availability of the Civilian Conservation Corps, several hundred thousand acres of crowded and stagnated young stands of hardwoods and mixed conifers and hardwoods in the East, southern Appalachians, and Lake States have been thinned to increase the rate of growth, and improve the character of the stand. Much of the young growing timber in the West, especially in South Dakota, Wyoming, and Idaho, has been treated for cultural improvement thinnings.

As the total stand of saw timber in our National Forests is approximately 600 billion board feet, the cutting of approximately 1 or 2 billion feet is much less than the annual growth. The principal timber sales are made in Washington, Oregon, California, Arizona, Idaho, Colorado, and Alaska, mentioned in order of quantitative importance. A vastly increased planting program has been inaugurated particularly in the Lake States and the South. Recently, 70,000 acres were planted in the National Forests in one year, which represents the planting of approximately $70,000,000$ trees. Large nurseries have 
been established at Manistee and Manistique, Michigan, Alexandria,* Louisiana and Wind River in southern Washington, and the Savenac nursery in western Montana. There are two million acres of forest land in need of planting in the National Forests and it is estimated that the nurseries will soon be producing from 100 million to 150 million trees or more annually. In order of importance most of the planting recently has been done in Michigan, Wisconsin, Minnesota, Idaho, and Washington.

Range and Grazing. The improvement and conservation of the range are among the most important activities, especially in some National Forests which are devoted to the maintenance of favorable grazing conditions rather than to timber production, recreational facilities, or other work. Recently, grazing permits on National Forests were granted annually for over $1,300,-$ 000 cattle, 6,000,000 sheep, 32,000 horses, and 11,000 goats. Most of the sheep were grazed in Idaho, Colorado, Utah, Oregon, and Montana, in order of importance.

Range improvements during a recent year included the building of 615 miles of fencing, 34 corrals, 79 driveways, 5 bridges, 516 water developments, and several other activities. The maintenance of these and many more improvements already installed requires the services of a large number of experienced men.

Recreation and Game. The National

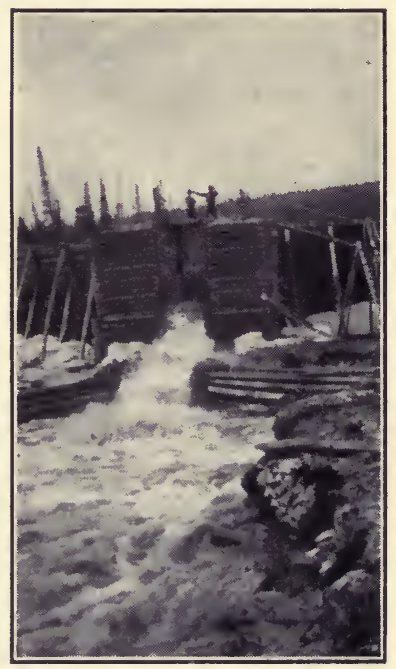

Fig. 104.-General view of splash dam used in the Roosevelt National Forest in northern Colorado to transport lodgepole pine cross ties from the woods to the timber treating plant at Laramie, Wyoming.

Forests offer excellent facilities for outdoor recreation because of their spaciousness, wide distribution over many parts of the country, scenic beauty, favorable climatic conditions, and the opportunities to study tree growth and other botanical specimens. Fishing and hunting, streams and lakes for boating, and many other natural attractions are provided. Over $35,000,000$ people enjoyed the recreational facilities of our National Forests in one year.

* In the Kisatchie National Forest, the Stuart Nursery of 50 acres has an annual capacity of 50 million one-year seedlings, largely longleaf and slash pines. Nine-months stock is used for field planting. 
Some 68 primitive areas with an aggregate area of over 10,000,000 acres have been set aside for future enjoyment. No further structural improvements other than for fire protection and no commercial developments are permitted on these areas. Furthermore, hunting is restricted or prevented on these areas. Under proper permit, leases are given for hotels, camp sites; summer cabins, and other recreational developments.

Interesting wild life has attracted wide attention throughout the country. It has also proved to be an important local resource, provid-

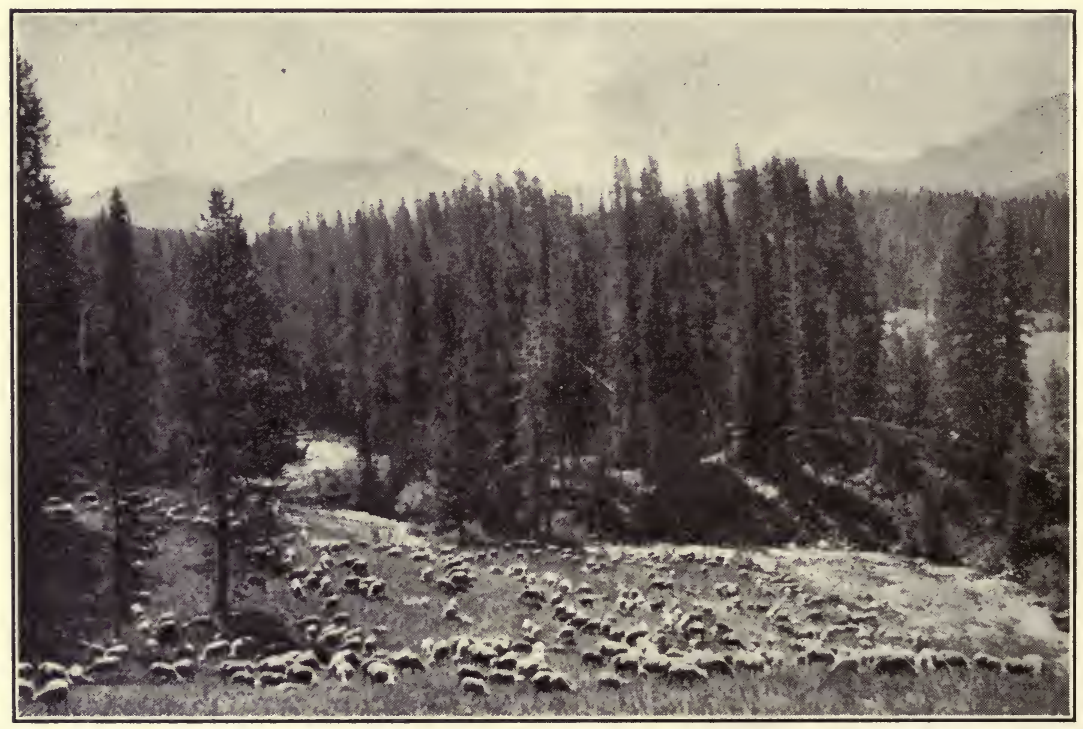

Fra. 105.- Sheep grazing in the Gallatin National Forest, Montana. Millions of sheep and cattle graze annually on the National Forests. Forage is an important resource on many forests.

ing substantial revenue for isolated settlers, licensed guides, and business enterprises. There are over 60,000 miles of fishing streams in the National Forests. Under proper protection and regulation, fishing and hunting have been immeasurably improved. The former serious conflicts between the grazing interests and those chiefly concerned with better hunting and fishing have been largely reconciled. It is estimated that since 1921 the number of antelope has increased $504 \%$, brown bear $26 \%$, deer $107 \%$, elk $119 \%$, moose $121 \%$, and mountain goats $102 \%$, but grizzly bear show a decrease of $7 \%$ and mountain sheep $12 \%$. It is estimated that there are the following big game in our National Forests: 5000 grizzly bear, chiefly in Alaska 
and Montana; 55,000 black or brown bear, chiefly in California, Washington, Oregon, Alaska and Montana; 14,000 antelope; 115,000 elk; 8000 moose; 20,000 mountain goats; 12,000 mountain sheep; and nearly a million deer.

Water Power. Under proper regulations, water-power projects are developed in our National Forests, generally in cooperation with the Federal Power Commission. There are 379 permittees operating under licenses in National Forests.

Roads and Trails. It is a consistent policy of the Forest Service to develop an adequate road and trail system. In order to make the

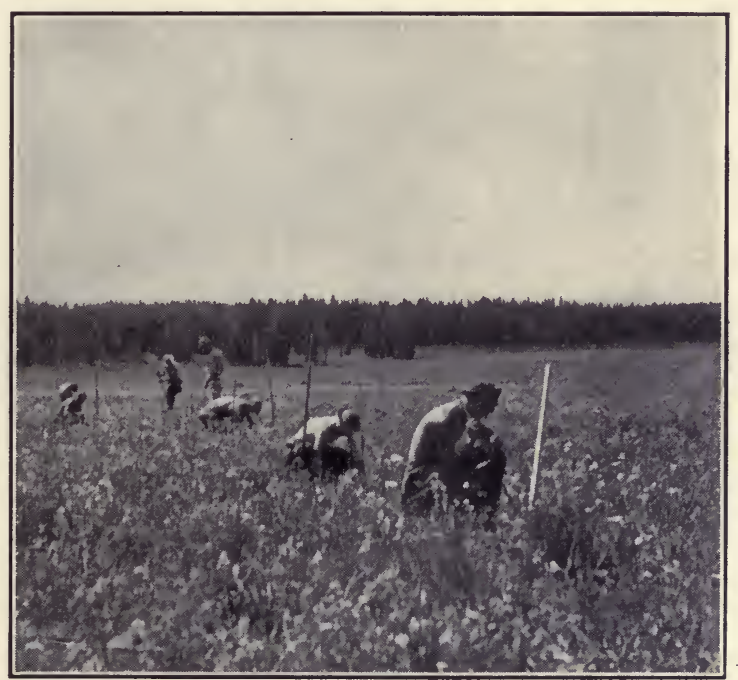

Fia. 106.-A rodent control crew poisoning the pocket gopher, which destroys much valuable forage in the National Forests and on the Public Domain in the West. Rodent control is a very important phase of grazing management in many parts of the Rocky Mountains, the Southwest and the Pacific Coast States.

forests more quickly and readily available to the public, to insure better fire protection, and to transport more economically the mineral, grazing, and forest products, the men of the Civilian Conservation Corps have been very effective in construction, improvement, and maintenance work on many thousands of miles of roads and trails on most of the National Forests of the West, East, South, and Lake States.

2. Research. Research is a very important and integral part of the work of the Forest Service. The chief activities in research are in the fields of forest economics, such as forest taxation and the forest 
survey, forest management investigations to improve the growing condition of the forests, studies to eliminate or reduce the fire hazard, improve the growing and utilization conditions in the naval stores industries of the South, erosion and stream flow investigations. A very comprehensive and effective laboratory known as the Forest Products Laboratory is maintained at Madison, Wisconsin, which is doing excellent work in effecting more efficient utilization of our forest products and in determining new and better uses of wood. Range investiga-

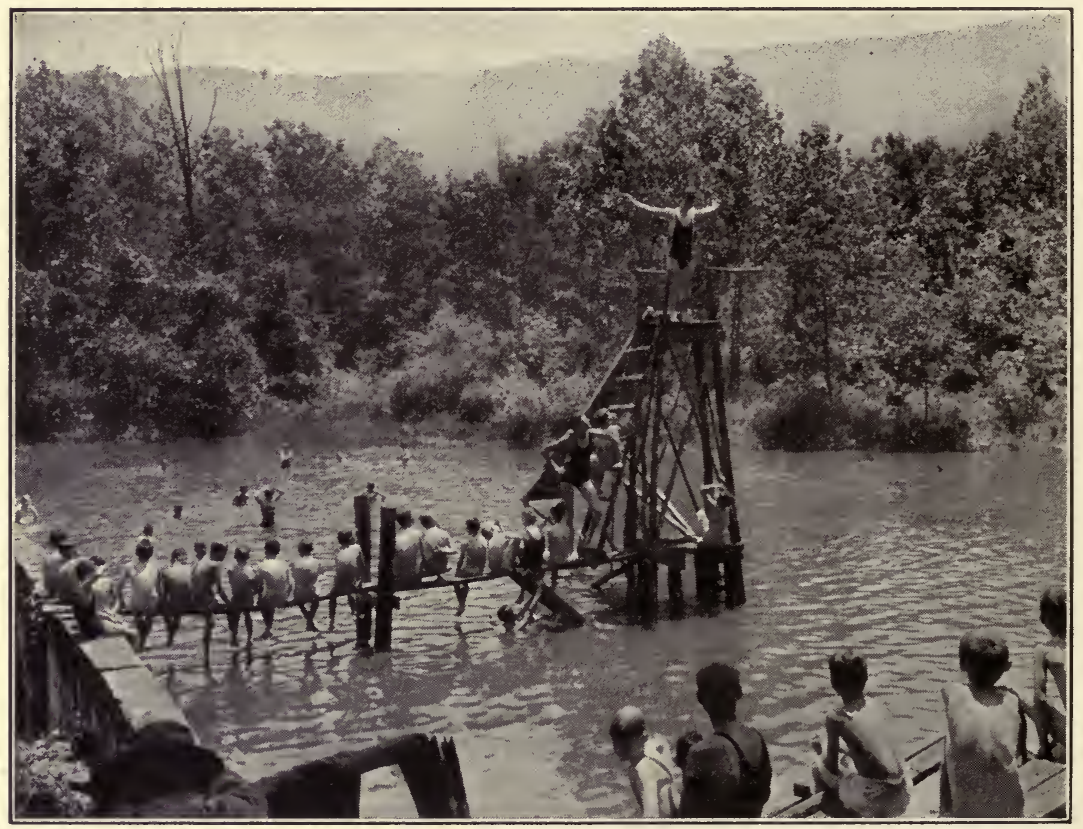

Fig. 107.-Swimming pool, Camp Kent (Lynchburg Y.M.C.A. Camp), George Washington National Forest, Virginia. Our forests are being used more and more for recreational purposes.

tions are also conducted at several experiment stations, chiefly in the West, at the Intermountain Forest and Range Experiment Station at Ogden, Utah, and elsewhere.

Effective research work was carried on in the Sierra Madre Mountains near Los Angeles, in connection with a most unusual and serious flood in southern California. This disastrous flood and forest fire caused the loss of 34 lives and did millions of dollars worth of damage to highways, orchards, ranches, and other property along the way. The maximum flood discharge from the burned-over drainage basin 
reached 1,100 second feet per square mile, carrying some 67,000 cubic yards of eroded débris, whereas the runoff in a nearby canyon a few miles distant was only 51 second feet per square mile and carried only 56 cubic yards of eroded material. In the pine regions of the Sierra Mountains in California the runoff and erosion were 31 to 463 times greater on burned areas than on unburned forest areas.

3. Extension Work or Public Relations. The third division of the National Forest activities is primarily educational and cooperative. It attempts to attract public attention to the formation of sound forest

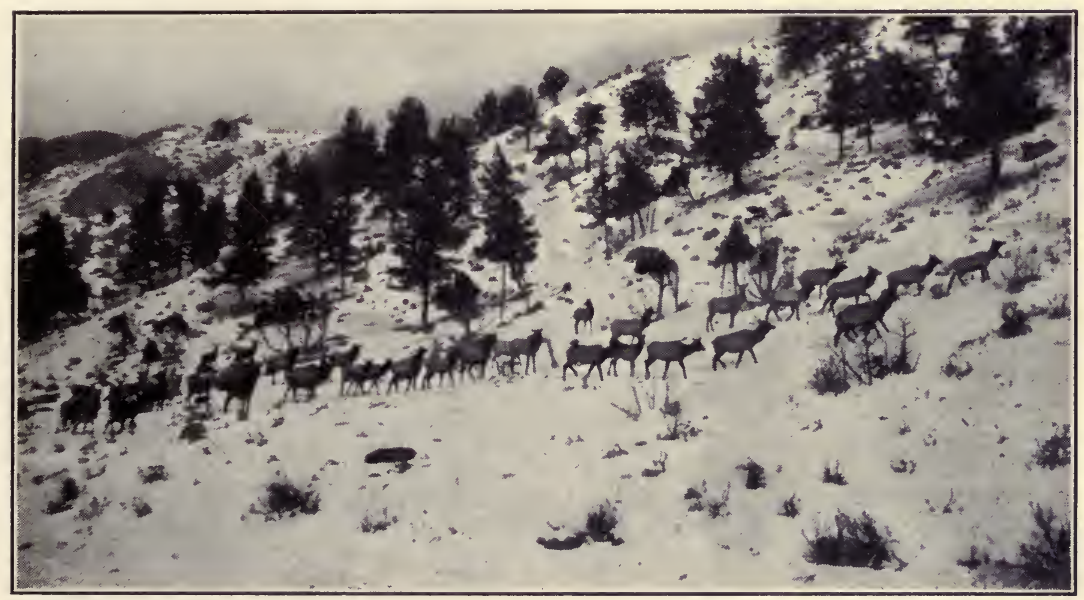

Fig. 108.-Elk seeking winter range in the foothills of the Absaroka National Forest, Montana.

policies as applied to federal, state, and private forests. It makes the findings of investigative work available for general use. It actively cooperates.with the various states, municipalities, and individuals owning timberland. It handles the state cooperative work in fire protection, farm forestry, and planting under the Clarke-McNary act. Recently the various phases of the work have been greatly expanded by assignment of responsibility for the activities of the Civilian Conservation Corps in National and State Forests as well as the forestry phases of the Tennessee Valley Authority, Soil Conservation Service, National Resources Board, and miscellaneous activities. 


\section{ORGANIZATION AND WORK OF A NATIONAL FOREST}

Each of the 150 National Forests of about one million acres in extent is in charge of a Forest Supervisor, who has an office, with technical and construction assistants, located in a large or centrally situated community, convenient to serve the public who may have business with the Forest Service as well as to inspect and study the business of the forest on the ground. For example, the Forest Supervisor's office for the Pisgah National Forest is at Asheville, North Carolina; for the Mount Hood National Forest, at Portland, Oregon; for the White Mountain National Forest, at Laconia, New Hampshire; for the Angeles National Forest, at Los Angeles, California; for the Boise National Forest, at Boise, Idaho; for the Allegheny National Forest, at Warren, Pennsylvania; for the Huron National Forest, at East Tawas, Michigan.

A National Forest is divided for administrative purposes into ranger districts, averaging five, each of which is in charge of a district ranger, who directs all work of timber sales, planting, marking, improvement cutting, grazing, fire protection, recreation, and Civilian Conservation Corps camp work, in his district. During the summer, temporary guards are employed to supplement the year-round force, especially in the forests of severe fire hazards. These guards are used on lookout towers, to patrol roads and trails for fire, building trails, supervising recreational activities, and other temporary and seasonal work.

The average ranger district of all the National Forests covers 279,000 acres, has a protective force of five fire guards who work $3 \frac{1}{2}$ months per year, and has 10 fires per year that burn over 600 acres. The average district has 22 timber sales and 31 grazing permittees, taking in about $\$ 4000$ in timber sale and grazing receipts. Each district has an average of 48 special use permits and 17,000 visitors per year.

The number and character of the personnel in each National Forest depend upon the intensity and nature of the work. Some forests serve primarily grazing interests; others are chiefly valuable for timber growing or watershed protection, as in southern California. Still others are chiefly valuable for recreational purposes. Many forests may combine all these activities as well as many special projects such as power projects and summer camps or planting, and fire protection.

The personnel and salaries of the various men who may be employed in the National Forests are as follows: 
Personnel

SALARIES

Forest supervisor

$\$ 2900-\$ 5400$

Assistant forest supervisor ............... 2300- 3500

Logging engineer ....................... 3200- 5400

Chief lumberman ........................ 2600- 3200

Associate forester ..................... 3200- 3800

Associate range examiner ................ 3200- 3800

Assistant forester ....................... 2600- 3200

Assistant range examiner .................. 2600- 3200

Forest ranger ......................... 2000- 2900

Junior forester ....................... 2000- 2600

Junior range examiner ................. 2000-2600

All the permanent positions in the Forest Service are in the classified Civil Service. Specialists for technical positions, such as lumber-

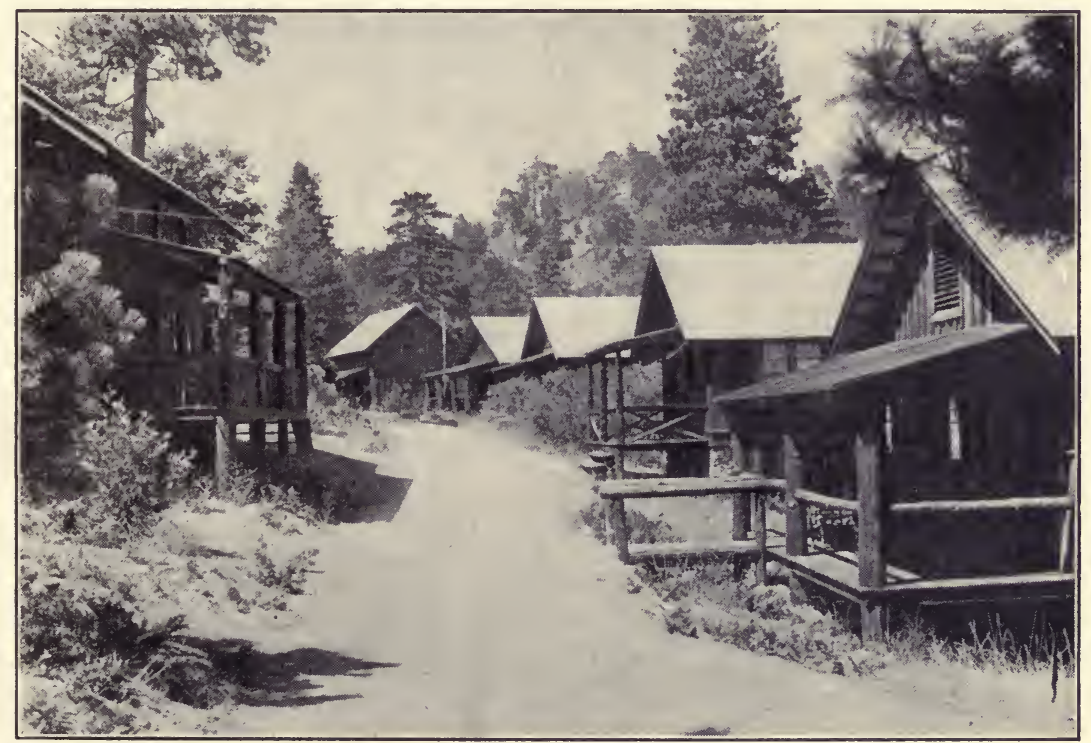

Fig. 109.-Summer homes in the Angeles National Forest, California. Special use permits are issued for summer cabins and many other purposes. The Forest Service derives a large revenue from these special use permits.

men, logging engineers, land examiners, forest ecologists, engineers, junior foresters, and forest rangers, are recruited by Civil Service examinations held each year. The more important executive and administrative positions are generally filled by promoting men who have shown special industry, ability, and merit. The forest supervisor and assistant supervisor are generally promoted from the ranks of junior foresters and forest rangers. The technical work of ranger districts 
has become so involved and difficult that professionally trained foresters are being used in place of the former local men who had had experience as woodsmen, cattlemen, or sheep men, and others who had acquired a knowledge of local conditions and problems.

\section{NATIONAL FORESTS AS MODELS OF FORESTRY PRACTICE}

The outstanding examples of successful forestry practice on extended areas in this country are to be found in our National Forests. They have been factors in the betterment of social and economic conditions, particularly in the local communities and immediately surrounding regions. The original objectives outlining the policy of Forest Service as stated by the Secretary of Agriculture on February 1, 1905, has been very carefully carried out to the effect that: "In the administration ... it must be clearly borne in mind that all land is to be devoted to its most productive use for the permanent good of the whole people. . . . All the resources are for use, and this use must be brought about in a thoroughly broad and business like manner under such restrictions only as shall insure the permanence of these resources ... the water, wood, and forage of the reservations are to be conserved and wisely used for the benefit of the home builders first of all. The continued prosperity of the agricultural, lumbering, mining, and livestock interests is directly dependent upon a permanent and accessible supply of water, wood, and forage. . .." 


\section{CHAPTER XV}

\section{NATIONAL PARK SERVICE AND NATIONAL PARKS}

\section{HISTORY AND DEVELOPMENT}

The National Park Service is a bureau of the Department of Interior, created by Congress in 1916 to administer and protect the $\mathrm{Na}$ tional Parks of the country. Prior to this date a number of areas had been set aside because of noteworthy scenic, geologic, botanic, or other

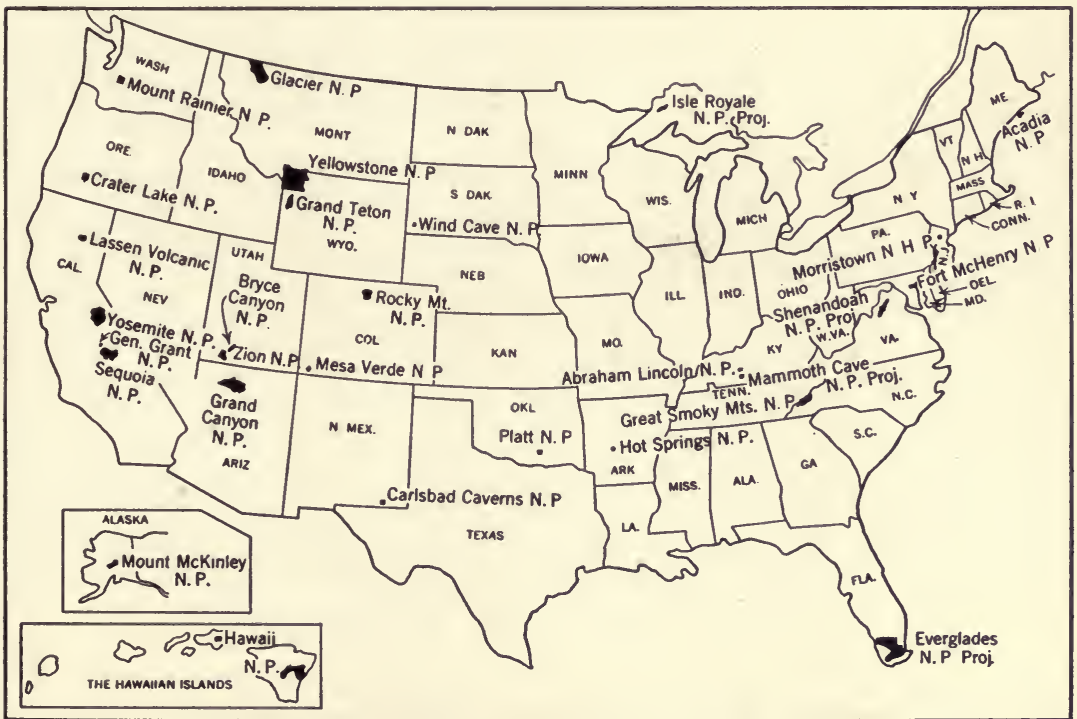

Fia. 110.-Location of National Parks administered by the National Park Service.

features, to be held in perpetuity for the benefit and enjoyment of our people without thought of commercial development or exploitation.

Beginning in 1872, the largest of our National Parks, Yellowstone, was created in northwestern Wyoming and overlapping into Montana and Idaho. As early as 1832 the Hot Springs Reservation in Arkansas was set aside because of its healing waters. In 1921 it became the Hot Springs National Park. 
In addition to the 24 National Parks, the National Park Service administers 68 other reservations known as National Monuments which are reservations of outstanding objects or locations of historic, prehistoric, or scientific interest; and 36 other areas mostly connected with our military history.

In most of the National Parks and some of the Monuments and military areas are to be found magnificent and unusually interesting primeval forests. Every effort is made to protect them from injurious

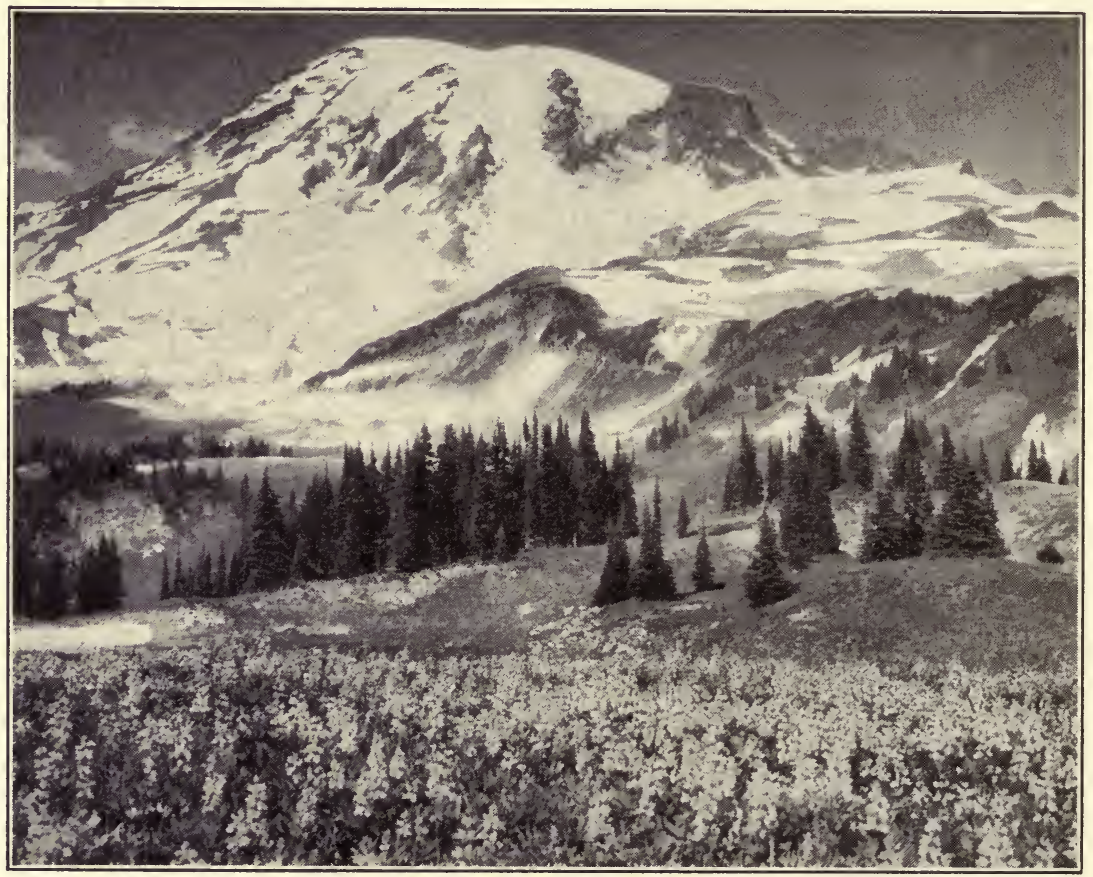

Fig. 111.-Flower fields in Paradise Valley, Mount Rainier National Park.

influences, such as forest fires, insect infestations, and tree diseases, and to maintain them in the best possible primitive conditions for the future. An important feature of this service is the developing protection and care of native wild animals. In fact, some of our finest and largest herds of elk, bison, antelope, mountain sheep, and mountain goats are to be found within the confines of our National Parks. The developmental work consists chiefly in the improvement and extension of existing roads and trails, together with their reconstruction and maintenance and the general supervision of hotels, camps, and other recreational accommodations for the convenience of visitors as 
well as the maintenance of such public utilities as light, heat, power, and water as may be necessary for the proper handling of the several million visitors who annually enter these parks.

Many requests are made for the creation of additional National Parks, but it has been the consistent policy to set aside only certain

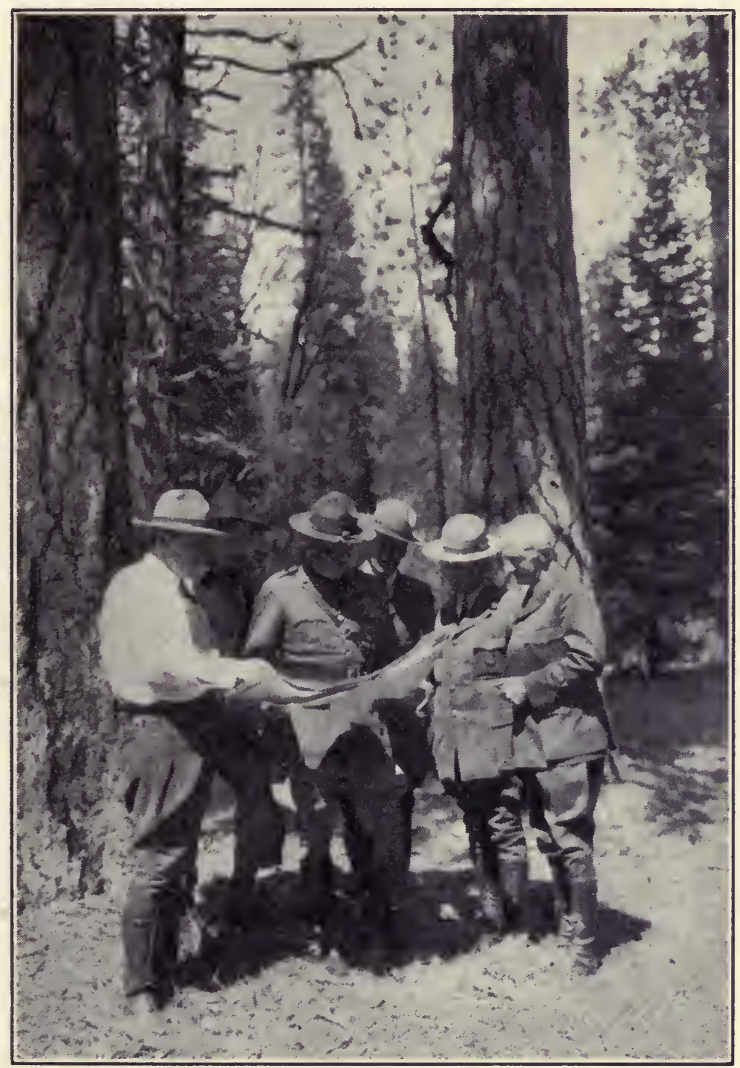

Fig. 112.-Park engineers, Rangers, Camp Superintendent and Camp Commander laying out plans for a Civilian Conservation Corps camp in the Yosemite National Park, California.

outstanding areas because of their scientific or scenic interest. Among the recent parks created for this reason have been the Grand Teton in Wyoming, the Carlsbad Caverns in New Mexico, and the Great Smoky Mountains in North Carolina and Tennessee. Congressional authorization has also been given for the establishment of the Everglades National Park in Florida, the Isle Royale in Michigan, the Shenandoah in Virginia, and the Mammoth Cave in Kentucky. 


\section{PURPOSES AND FUNCTIONS AS DISTINCT FROM NATIONAL FORESTS}

The National Parks and Monuments are chiefly notable for their superlative values as scenic wonders and marvels of nature as well as for outstanding historic and scientific interest. The preservation of these values is a matter of great national importance and requires the

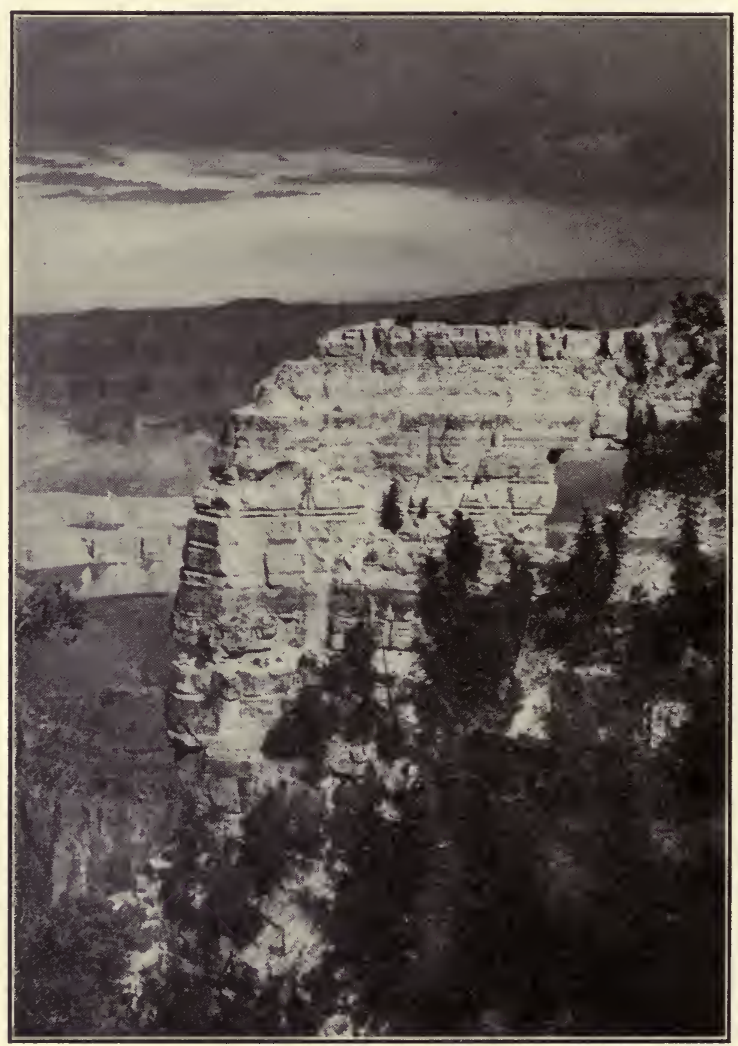

Fig. 113.-Angels Window at Cape Royal, Grand Canyon National Park, Arizona. This canyon is 4 to 18 miles across, a mile deep and 217 miles long, in a plateau 4000 to 8000 feet above sea level.

exclusion of all commercial use and exploitation of these lands or their. resources. The primary purpose of our National Forests, however, is for present and future use to best serve local as well as regional and national purposes. They are fundamentally administered for multiple purposes.

The respective objectives of the National Parks and National 
Forests have been carefully demarkated on the basis of fundamental distinctions in their uses. National Forests were originally created for timber production; to conserve water flows at the headwaters of our streams used for irrigation, potable, and power purposes, as well as for navigation; for the grazing of many thousands of cattle and sheep; for the development of power projects; and for many varieties of recreational use. The last named is paramount in the administration of the National Parks and Monuments. In effect, therefore, the National Forests are largely for a great variety of purposes,

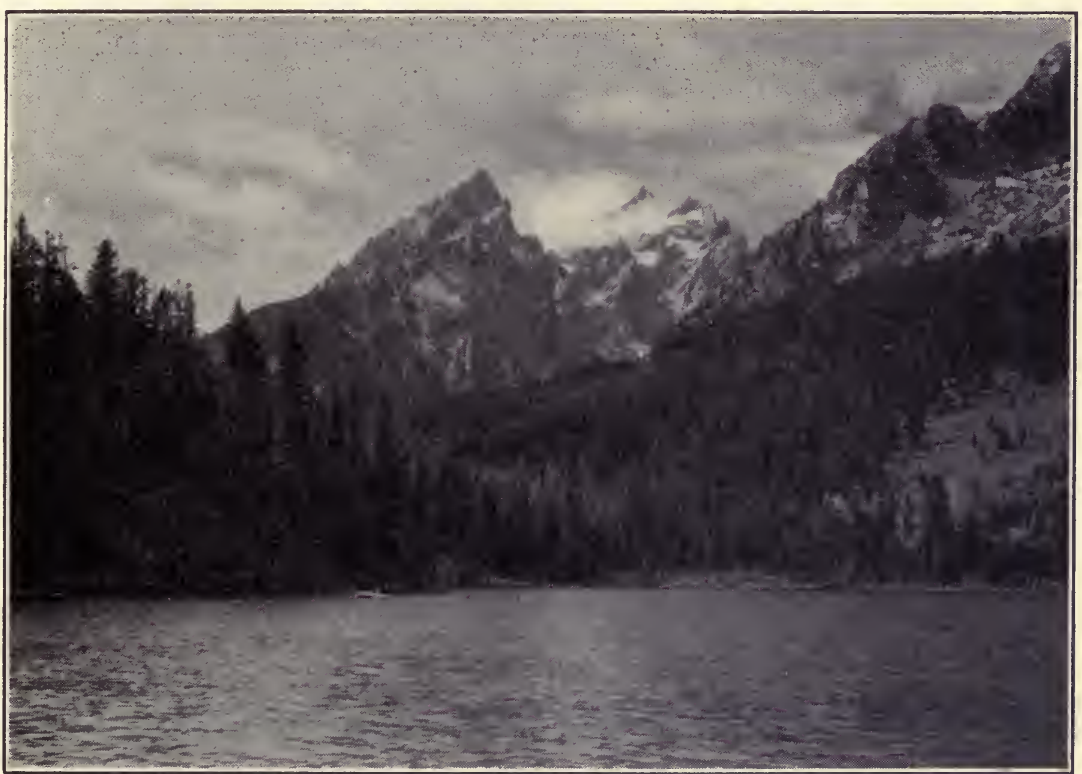

Fig. 114.-Grand Teton National Park. Teewinat, the Grand Teton and Mt. Owen, from String Lake.

each one of which may be the outstanding feature in an individual National Forest. In some of them the establishment and maintenance of public camping grounds, picturesque glens and waterfalls, and other scenic features, local recreational resorts, such as hotels, picnic areas, and lakes for swimming and boating, may be of outstanding importance. Though the forests may be primarily used for grazing purposes or for the maintenance and protection of the water flows as in southern California, the objectives of timber growing and cutting, grazing, water-power development, and other features of National Forests are utterly excluded from the work of the National Parks and Monuments. The forests, wild flowers and plants, and wild life are main- 
tained as far as possible in their primitive condition, no commercial use is permitted, and the development is entirely for the people seeking recreation and enjoyment in ideal wilderness and primitive conditions.

In 1933, by presidental executive order, two National Parks, 11 National Military Parks, 10 National Monuments, 10 battlefield sites, and 4 memorials were transferred to the National Park Service from the War and other departments.

\section{LOCATION, SIZE, AND FEATURES OF THE NATIONAL PARIS}

Most of the National Parks are located in the West because of unusual features offered in the Rocky Mountains and in the Sierra

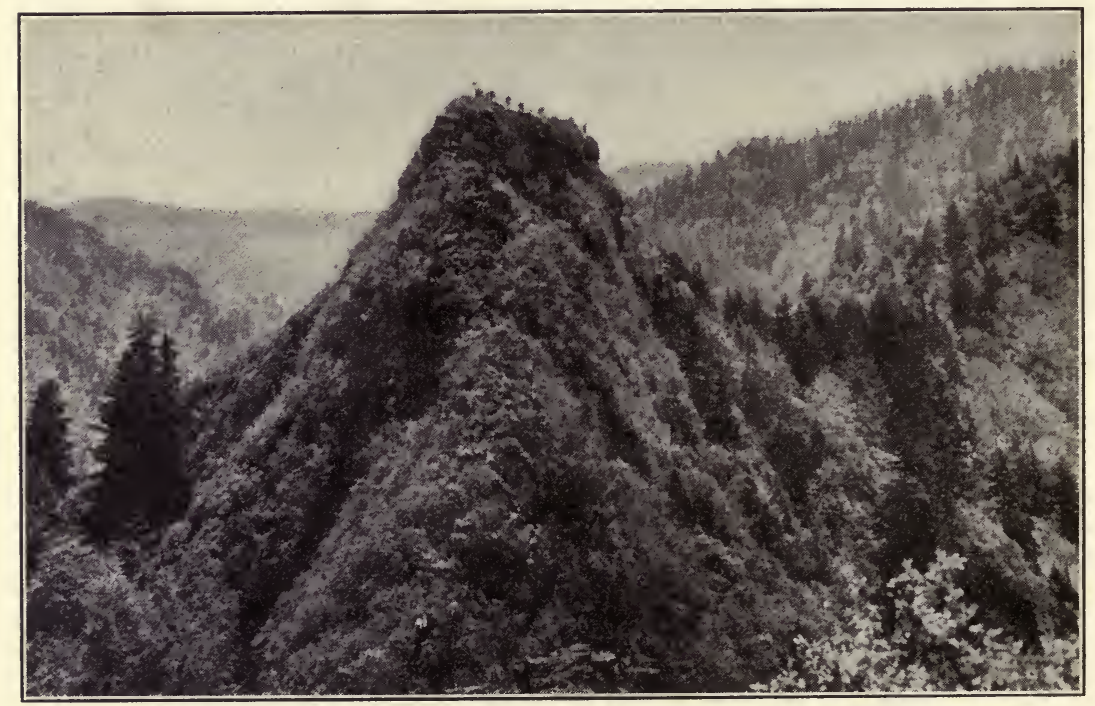

Fig. 115.-Chimney Tops in the Great Smoky Mountains National Park.

Nevada and Cascade Ranges bordering the Pacific Coast. There are 24 National Parks and 68 National Monuments and other reservations.

The parks vary in size from the Yellowstone, which contains 3438 square miles or 2,200,240 acres, to the smaller ones known as Carlsbad Caverns, comprising 9,959 acres in southeastern New Mexico, the Abraham Lincoln of 110 acres in Kentucky, and the Fort McHenry of 47 acres in Maryland.

Each park is featured by some outstanding scientific interest; thus the Grand Canyon of northern Arizona is regarded as the most sub- 
lime spectacle in the world and the greatest example of erosion; the Sequoia Park in mid-eastern California contains $60 \%$ of all the remaining sequoias and the largest single tree in the world, known as the General Sherman tree, $361 / 2$ feet in diameter and 272 feet in height, as well as towering mountain ranges and great canyons and precipices; the Great Smoky Mountains Park, of the Appalachian Range, contains over 150 species of hardwoods in addition to conifers and over 1500 varieties of wild flowers; the Mount Rainier Park contains the largest single peak glacier system, with 28 glaciers extending over 48 square miles of surface; the Mesa Verde Park contains the most notable and best-preserved cliff dwellings in the United States; Rocky Mountain Park includes the heart of the Rockies and a magnificent series of peaks ranging from 11,000 to over 14,000 feet in elevation; the Yosemite, containing a valley of world-famed beauty, lofty cliffs, three groups of sequoias, and many waterfalls; and the Yellowstone has more geysers than all the rest of the world, with the Canyon of the Yellowstone and many lakes, mountains, and streams on a high plateau 7000 feet or more in elevation.

The following list shows the name, location, date when first established, and area of our National Parks: 


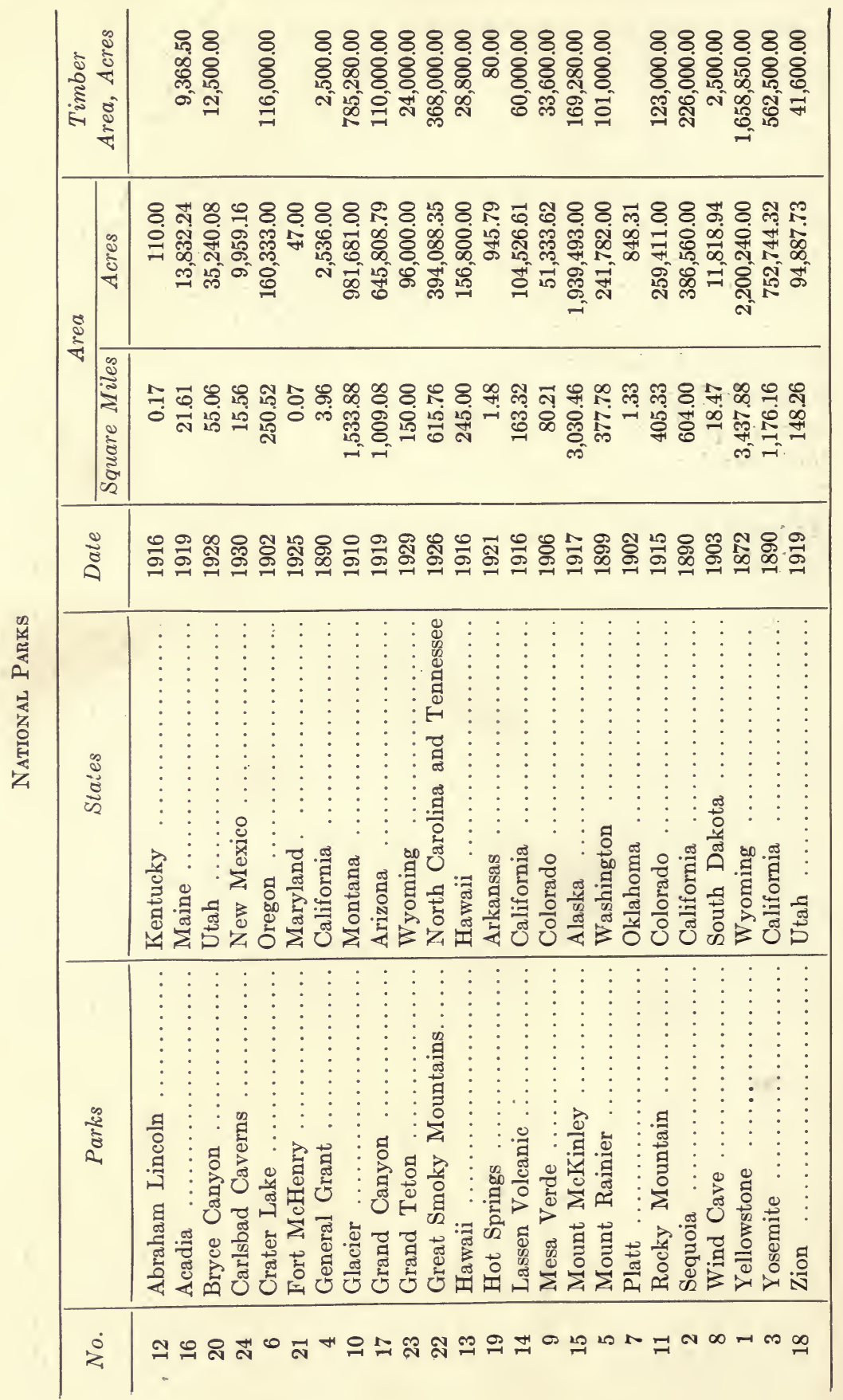




\section{CHAPTER XVI}

\section{STATE FORESTS AND FOREST POLICIES}

\section{HISTORY}

During the reconstruction era following the Civil War, there was widespread enthusiasm for tree planting and the better protection of forests. Great fires had ravaged our woods, and a strong interest was displayed in planting the treeless plains of the prairie states. Still later, sentiment became focused on the subject, resulting in definite legislative action. This appeared to be a national movement and was country-wide in its extent. Federal legislation in 1876, as described elsewhere, stimulated definite action by the states more thoroughly than any other single factor. In 1885, state forestry made an auspicious beginning, for in that year, four states, New York, Ohio, Colorado, and California, enacted legislation formulating forestry organizations. In the last two states, the value of forestry in protecting water flows for irrigation purposes was the initial stimulus. Crystallization of sentiment has continued along similar lines in these and many other states of the West. State forestry legislation became most active in New England and the East, then in the Lake States or Central West, and finally in the Rocky Mountain and Pacific Coast States. Although the southeastern and southern states were generally the last to take up state forestry, they have made notable progress during recent years, especially since 1921. Some of them now have the most effective laws and organizations in the entire country.

Legislative action in state forestry generally follows the leadership of one or more able men, like J. T. Rothrock in Pennsylvania, where a Commissioner of Forestry was appointed in 1895 and an adequate policy for state forestry was enacted in 1897. S. B. Green made notable contributions in Minnesota and was a great bulwark of strength in formulating legislative action in 1899 to provide for forest conservation and better fire protection.

A great forward advance was made in the period between 1901 and 1910, during the régimes of President Theodore Roosevelt and Chief Forester Gifford Pinchot. The influence of this president and his chief forester had great weight in the formation of both federal 
and state forest policies throughout the country. Prior to 1901, no technically trained foresters were employed in state service. There soon followed a wise insistence that state forest policies should be directed by trained and experienced foresters, and that they and their staffs should be free from political interference or influence. Disastrous forest fires, notably in Minnesota, California, Idaho, and New York, contributed to a quickening of activity in state organizations, laws, and policies.

'The Weeks Law of 1911, providing for cooperative fire protection by the Federal Government in behalf of the various states on forested watersheds of navigable streams, exerted a powerful influence in the creation of additional state forestry organizations and the strengthening of those already under administration. Now 39 states cooperate with the Federal Forest Service, as explained elsewhere.

\section{NUMBER AND CHARACTER OF STATE FOREST ORGANIZATIONS}

Of the 48 states of the Union, 42 now have administrative agencies, laws, funds, and experienced personnel to carry on forestry activities. Pennsylvania has 61 technical men in its organization, and New York 57. The South generally leads the country in its legal provision for technical men to head the forestry work, and every southern and southeastern state now has an active forest organization. North Carolina was one of the first states of the Union to establish a forest policy and has been a consistent leader in the movement.

Activities vary widely, depending upon the character of public sentiment reflected in legislation, urgency of certain phases of the work, and nature of the forest and its ownership. In some states, principal emphasis is given to protection from fire, insects, or disease; in others, to the acquisition and administration of state forests. Still others are principally concerned with planting of idle lands, shelterbelts, and windbreaks. Pennsylvania is generally recognized as having the most effective, balanced, and well-developed state forestry organization in the country.

\section{FUNCTIONS AND ACTIVITIES}

The work in each state as indicated depends upon local circumstances and requirements for the various phases of forestry work. Altogether, however, the functions and activities consist of the following: 


\section{The Purchase, Protection and Maintenance of State Forests.} In some states, as in Washington, Oregon, and Idaho, the state forestry organization is also interested in the protection of private lands from fire and pest attacks. There has been a general tendency to extend fire protection either directly or cooperatively over all the forests of the state, irrespective of ownership.

2. The Establishment and Maintenance of State Tree Nurseries and Reforestation Activities. These have been the principal activities in some states, as in New York, where little trees are distributed at cost to the people as well as for planting on State- Forests and lands owned by public agencies, like hospitals, prisons, colleges, and parks. There has been a widespread increase in the growing of forest trees for planting in many of the states, notably in Michigan, Indiana, Massachusetts, Wisconsin, Ohio, and several southern states.

\section{Promotion and Stimulation of the Private Forest Owner to} Practice Better Forestry. Separate divisions of the State Forest organization are sometimes devoted to this single purpose. The work is done by written and oral advice to the owners of woodlands, the establishment of demonstration forest areas under management, and by practical cutting, planting, and improvement thinning demonstrations. Bulletins, pamphlets, and press releases are issued on matters of popular interest such as reforestation, fire protection, recreation, and management of woodlands.

4. Education and Extension. An important function of all State Forest Services is to educate the general public, including school children, regarding the necessity of more and better forests. This is accomplished by radio broadcasts; talks before luncheon, women's, civic, patriotic, and fraternal clubs; exhibits at state and county fairs; Arbor Day celebrations; the distribution of publications dealing with the improvement of woodlands, reforestation, and fire protection. The laws of Georgia, Louisiana, Mississippi, North Carolina, and Tennessee require the teaching of forestry by the regular. staffs of teachers in both primary and advanced public schools. In Ohio, South Carolina, and West Virginia, a course of study in forest-fire prevention for the schools is prescribed by law. Tennessee has led in requiring forestry to be included in the public-school curriculum.

5. Cooperation with the Federal Government and with Private Organizations in Fire Protection, in the Growth and Distribution of Trees, and in Woodlot Forestry. Under certain conditions, as explained elsewhere, the Federal Government contributes funds to the various states for these activities. Aside from this, the individual 
states may cooperate in fire protection or in other work on private or corporate timber properties.

6. Research. Whenever educational institutions are present, this activity is generally left to them. If not, however, much investigative work may be carried on if funds are available. Special state-supported research centers have been established, as at Mont Alto in Pennsylvania, Cloquet in Minnesota, and Roscommon in Michigan.

There are now 4,395,000 acres in State Forests and another 21/4 million in process of acquisition. There are also over $2 \frac{1}{2}$ million acres in State Parks which are frequently managed or operated as State Forests. Of all the State Forests, $89 \%$ of the area is in the Northeast, the Middle Atlantic States, and the Lake States. The State Forests of Montana, Idaho, and Washington comprise a large share of the balance.

There is a sharp distinction between the objectives of National Forests and National Parks. This, however, does not exist to the same degree in the management of State Forests and Parks. The federal distinction is best shown in the development and use of all resources in the National Forests, whereas there is no commercial use or development in National Parks. Often the objectives in management may be the same in State Parks as in State Forests. For example, in New York no cutting is permitted in over 2 million acres of State Parks in the Adirondack and Catskill Mountains, by constitutional prohibition, whereas in other State Parks, outside these mountainous areas, cutting is permitted. Many of the western states obtained their State Forests from the school sections 16 and 36 in each township, which were allocated to the various states from the public domain. Each state has a somewhat different policy with respect to the distinction between State Forests and State Parks. Sometimes both come within the same department, and sometimes there is a separaie organization for each activity.

Similarly, the organization of the forestry work varies widely. The state forester is also known as director, forest commissioner, or chief of a division of a State Forest or conservation commission. $\mathrm{He}$ may be appointed by the governor as in Georgia, Montana, Iowa, Maine, and Vermont, or by a state board or commission as in Texas, Virginia, Florida, Mississippi, Michigan, Idaho, and Oregon. Tenure of office may be optional with his superior or for a definite term. $\mathrm{He}$ may be subordinate to a board, commission, or commissioner, or he may report directly to the governor. In relatively few of the states is the work under or connected with an agricultural board or department. 
More than 27,000 men are employed permanently or temporarily in our State Forest organizations, of whom only about 350 are technically trained foresters. It is possible that gradually more trained personnel will be employed. Pennsylvania has more than 4000; North Carolina, about 4000; Tennessee, about 4000; New York, 3000; Virginia, 1400; West Virginia, 9000; Washington, 386 men in their forestry organizations, a very large proportion of whom are part-time men engaged principally on forest-fire protection.

\section{TRENDS AND POLICIES}

Within recent years there has been a noteworthy expansion in the acquisition of State Forests and Parks, in better systems of fire and pest control, and in the reforestation of idle, burned, or submarginal lands. Facilities for recreation which include hunting and fishing have also been largely extended. The Civilian Conservation Corps program has greatly stimulated several of these activities. In order to obtain some of these 200 -men camps, it was necessary for the states to own the lands on which these men were worked. Since the organization of the Corps over 600,000 acres have been added to State Parks alone, and many hundred thousand acres have been added to the area of State Forests.

Many states contain both Federal and State Forests, among them Pennsylvania, Minnesota, Wisconsin, Michigan, Vermont, New Hampshire, Idaho, Colorado, Alabama, Mississippi, and Texas. In some states, local authorities are opposed to further extension of National Forests within their boundaries. Generally, however, various states have welcomed the purchase and establishment of federal forests. From a broad viewpoint, the Federal Government should acquire the more remote, inaccessible, poorer, and mountain lands for interstate watershed and water-flow protection, whereas the smaller units, the more accessible and better forest lands, should be acquired by the states. Some foresters think that a very large share of our forest lands should be owned and managed by such federal agencies as the Forest Service, National Park Service, and Indian Service. Others contend that a proper balance should be maintained between federal and state ownership. Still others believe that the further extension of federal ownership is undesirable within some states. The question of federal versus state rights is involved. Where both State and National Forests are found within a single state, there should be a coordination of policies and objectives. This is usually and happily the case, as both agencies are seeking the same common good and welfare of the people. 
In some states the major productive forest areas are already in National Forests, as in Idaho, Montana, and Colorado, so the opportunities for expansion of State Forests may be limited. However, about four-fifths of all forest areas of all kinds are still in private ownership, so generally there is a large opportunity for considerable expansion of State Forests and Federal Forests as well. Many authorities believe, however, that we should encourage the practice of forestry by corporations and individuals, like farmers, lumbermen, mine companies, pulp and paper companies, water companies, fishing and hunting clubs, and resorts, rather than leave the responsibility entirely to federal and state agencies.

In Arizona and New Mexico where there are large holdings of both state and federal forests, the state lands are managed and protected and the mature timber is sold by the U. S. Forest Service under a joint agreement. In some states, as Nevada, Wyoming, and Utah, there are insufficient forest areas outside the National Forests to justify an extensive or well-supported state forestry organization. 


\section{CHAPTER XVII}

\section{COUNTY, TOWN, AND COMMUNITY FORESTS}

For many centuries communal forests have been owned and operated successfully in many parts of Europe. The establishment of community forests in this country may be directly attributed to the success attained by these forests in Europe, where in extreme cases the citizens of these towns are free of taxation for schools, roads, police, and fire protection because of the profits obtained from the practice of forestry on lands owned by these communities on the surrounding or adjacent hillsides.

As early as 1882, Massachusetts authorized the acquisition of municipal forests. Later, New Jersey in 1906, Pennsylvania in 1909, Minnesota, New Hampshire, and Indiana in 1913, and Vermont in 1915 authorized the establishment of the communal forests. The city of Fitchburg, Massachusetts, claims to have established the first town forest under a state law in 1914. The communal forests, or those known as town or county forests, received considerable impetus during the decade after the World War. A special premium was offered to towns in Massachusetts for establishing forests. The Massachusetts Forestry Association was very active in this work.

In New York, the town and county forest movement has made considerable progress, especially following the law passed at the behest of the State Reforestation Commission. State subsidies are offered to counties for the acquisition, planting, and management of county forests.

Figures by Tillotson show that there are 390 town and municipal forests in New York, 90 in Massachusetts, 82 in New Hampshire, 45 in Michigan, 37 in North Carolina, 23 in Ohio, 23 in Connecticut, and several others in Pennsylvania, Alabama, South Carolina, and other states. Altogether there are 801 town and municipal forests in the United States, with a total acreage of 473,000 acres.

Similarly, the county forest program has enjoyed progress during recent years. In Wisconsin, impetus was given by special legislation providing for state participation in expense. There are 11 county forests in Wisconsin with a total area of more than 46,000 acres. In 
New York a law was passed providing for state contributions up to $\$ 5000$ per year to any county for land purchase and reforestation and protection. That state has 34 county forests with a total acreage of 18,000 acres. Other states having county forests are Illinois, with 7, and New Jersey, Pennsylvania, Mississippi, and New Hampshire. In Wisconsin tax-delinquent lands revert to the county. A large share of the county forests have been organized from this form of acquisition.

Several counties in California have made substantial progress in forestry, notably Los Angeles, Ventura, and Santa Barbara. The first has annually appropriated as much as $\$ 1,000,000$ for forestry work, chiefly fire protection for the nearby mountain watersheds. Fire followed by floods has done enormous damage in parts of the Sierra Madre and other ranges in southern California. Cooperation with federal, municipal, and private agencies has been active and effective.

An excellent opportunity for luncheon clubs, civic organizations, chambers of commerce, boy scouts, and other local groups is provided in the purchase, planting, protection, and operation of community forests on the outskirts of nearly all our communities, except the largest urban centers and those located in regions of rich agricultural soils. More than $50,000,000$ acres of land, located in nearly every state, are idle and abandoned, some of which could be profitably devoted to county, town, or communal forests. Many water departments of communities have planted millions of trees about the watersheds to insure a clean and adequate supply of water for the future. 


\section{CHAPTER XVIII}

\section{PRIVATE FORESTRY}

\section{RELATIVE IMPORTANCE}

Private individuals, companies, and groups own $79 \%$ of all the commercial forest. These are chiefly lumbermen and farmers. Others representing ownership in this class are pulp and paper companies, mining companies (chiefly those owning large tracts of coal-bearing areas) water companies to protect the watersheds of drainage basins, and private estates which may be handled chiefly for aesthetic purposes but may also include commercial objectives as well. There are also hunting and fishing clubs and private corporations such as the Singer Sewing Machine Company, the International Harvester Company, the Eastman Kodak Company, the Ford Motor Car Company, and many others which are interested in maintaining adequate reserves of timber for the production of lumber, wooden parts, or wood products that are used in their manufacturing enterprises. Most of the larger holdings controlled by private companies are found in the Pacific Coast region and in the South. Some of these companies own or control 50,000 to 500,000 acres of timberland or more.

It is very apparent, therefore, that if forestry is to be widely practiced in this country, the privately owned forests furnish the greatest opportunities, at least in area.

Some foresters believe that the government and states should own and control a very large share of our commercial forest properties. The high mountain areas, the protection forests at the headwaters of our major streams, and the remote and inaccessible forest areas that probably cannot be profitably managed by private individuals and corporations are largely contained within our National and State Forests and Parks. The better class of timberlands should be left to private ownership. There is a proper balance between private and public ownership which should be maintained in the future unless it becomes a part of our governmental policy to own, control, or operate many forms of enterprises. This policy, however, does not seem to fit in with our American traditions. 


\section{PAST HISTORY AND TRENDS-WHAT HAS BEEN ACCOMPLISHED}

The practice of forestry on privately owned property is often referred to as industrial forestry. Many attempts have been made by private owners to perpetuate and continue the growth of timber on their properties. The earliest efforts were in the direction of better fire protection to prevent both current and prospective losses of growing timber. Then several companies attempted conservative cutting methods designed to assure the future growth of timber by taking only the larger trees, by leaving seed trees, by more complete and efficient utilization and by other methods intended to serve both the present and future requirements of the forest-holding company. Still later, several companies, particularly in the Northeast, the redwood region, and the southern pine region, established nurseries for growing trees for reforestation purposes. Notable examples were the Brown Company nursery at Oquossoc, Maine, the large nurseries and plantations of the Great Southern Lumber Company at Bogalusa, Louisiana, and the Industrial Lumber Company at Elizabeth, Louisiana, and several redwood lumber companies in northwestern California. Concurrently with this progressive advance, many attempts were made better to control insects and diseases, especially in Maine, New York, and the Lake States. Through studies conducted by the U. S. Forest Service, improved methods of turpentining were introduced in the longleaf pine and slash pine forests of the Southeast. Still later, many companies introduced cutting methods intended to promote natural regeneration and thus increase the rate of growth on a sustained yield basis. The Finch Pruyn Company cuts its spruce pulpwood timber to an 8-inch minimum diameter limit in the Adirondacks in New York. Several companies in cooperation with the Forest Service have made careful studies to determine the profitable diameter limits for cutting, which is discussed later under the subject of selective logging.

A study* was made to determine the extent of forest management policies on private holdings of more than 1000 acres. This survey disclosed that 268 companies were making definite efforts to grow timber on over 20 million acres; 42 additional companies were giving their holdings excellent care without definite timber-growing purposes but where favorable opportunities existed to practice forestry. These companies represent over 2 million acres. There were 178 companies

* Conducted by a committee of the Society of American Foresters, Washington, D. C., under the chairmanship of S. W. Allen, 1930. More recently revised by the U. S. Forest Service. 
using careful cutting methods intended to permit natural regeneration on over 10 million acres. About 40 companies were attempting to put their holdings on a sustained yield basis on $3 \frac{1}{2}$ million acres. There were 253 companies providing effective fire control independently of public cooperation in addition to other forestry activities on about 17 million acres. Seventy-five companies were practicing close and intensive forms of utilization on their logging operations on about 5 million acres. Fifteen companies maintained nurseries for growing trees for planting, the number of trees produced annually being 30 million. Seventy-six companies were planting trees and had planted over 100,000 acres. In addition to these definite advances in the practice of forestry on private holdings, 79 companies employed foresters in timber production, the total number employed being 146 . Seventy-seven companies use consulting foresters on a part-time basis. Sixty companies were spending money to eliminate or control insects or diseases, and 46 companies in the South and Southeast were using improved methods in turpentining operations on $1,500,000$ acres of longleaf and slash pines (chiefly second-growth timber). Some companies have logged their forests two or three times and still have a good stand of rapidly growing young timber for another cut.

These figures indicate a very definite forward advance in the progress of forestry on private holdings.

Some of the best opportunities are on farmer's woodlots, and much progress has been made there. However, a very large opportunity exists for improved practice of forestry on the smaller tracts and woodlots, especially east of the Mississippi River, as indicated elsewhere in the text.

\section{THE FARM WOODLAND AND THE SMALL TIMBER TRACTS}

The farm woodlands offer excellent opportunities for the practice of forestry, and considerable progress has been made in that important private ownership group.

Farm woodlands comprise $25 \%$ of all the commercial forest land of the nation-about 126 million acres. East of the Rocky Mountains they include more than three-fifths of all the forest. Probably the most stable form of private ownership is represented in these small tracts. A crude form of forestry has generally been practiced on these properties, which are usually from 5 to 50 acres or more in extent and constitute an important part of the farm. These woodlands have supplied fuelwood for home consumption (generally about 17 cords per family per year), or for sale. They are also an impor- 
tant source of supply for saw logs for lumber, for repairs, bridges, and construction work about farms, posts and rails for fencing purposes, and for miscellaneous uses, such as maple syrup and sugar in the Northeast and North, and naval stores in the Southeast. Of all the commercial forests privately owned, these woodlots contain about 35 million acres of saw timber estimated to contain 123 billion b.f. compared with 90 million acres in industrial ownership, estimated to contain 864 billion b.f. Therefore they constitute a very important source of our timber supplies.

The tendency in the management of these small tracts has been to fell the better species and the larger trees for current needs and to leave the poorer individual trees and species to develop into the forests of the future. This constant elimination of the better-quality stock and the failure to improve growing conditions has very generally resulted in a gradual deterioration of the woodlot as a source of farm timbers and products for sale in the future. Too many small trees that would produce a $2^{\prime \prime} \times 4^{\prime \prime}$ piece or small boards have been cut. These small and medium-sized trees grow rapidly and are laying on a most favorable rate of wood growth. They should not be cut until they reach larger sizes.

Many woodlands have been planted in the prairie states for shelterbelts and windbreaks. Many trees have also been planted on the farmsteads and in connection with woodlots for shade purposes for both man and animals. Submarginal lands have been planted on many farms for timber, Christmas trees, and fence posts.

The chief problem of the woodlot owner is to know when, where, and how to sell his surplus timber products at a profit. The woodlot may be the important or major source of farm income. Too frequently the entire lot is sold for a lump sum to a portable-mill owner or lumberman without proper cutting restrictions. Perhaps a few of the best trees may be sold at a relatively low price for stumpage. Many owners sacrifice a good growing stock for immediate cash returns. Sometimes this is unavoidable. A vast total quantity of Christmas trees, cords of pulpwood, poles, piling, posts, grape stakes, mine timber, veneer and cooperage logs, distillation wood, and other materials are produced on these small tracts. In fact they compose a large source of these materials in many sections of the South, the Central States, the Northeast, and the Lake States. Even in Washington and Oregon the farm woodlot is becoming of real importance. The total value of woodlot produce was 242 million dollars in a recent year. The South and Southeast contain more than 57 million acres of farm woodlots-more than any other region. 
The best stimulus for improved farm woodlots is in finding a profitable outlet for the products. Much emphasis is given to better planting, thinning, cutting, protection, and other silvicultural practices, but little has been accomplished to assist the farmer in securing a good price for his product. If his forestry efforts are successful and profitable, he will be encouraged to practice better forestry on his woodlands for the future.

R. K. Day of the Forest Service has pointed out that one owner in the Ohio Valley has kept an accurate record of cash sales for 13 years since the World War. He received a total cash income of over $\$ 10,000$ or a return of $\$ 10.73$ per acre per year from 75 acres of farm woodlands. The area is classified under the Indiana tax law so the yearly taxes do not exceed 10 cents per acre. All the work was done by the farmer and his immediate family, and no hired teams were employed. This owner cut, sold, and delivered 266,000 b.f. of hardwood logs at an average price of $\$ 35.00$ per m.b.f. He also sold and delivered 643 cords of fuelwood at an average price of $\$ 3.10$ per cord, and supplied his own needs of 25 cords per year. Although over 700 b.f. per acre were cut during the last two years, the woods appear to be at least $90 \%$ stocked.

Much damage to reproduction and young growth has been inflicted by the grazing of domestic animals, especially in the hardwood forests of the Central States, as in Indiana; Ohio, and Kentucky.

Considerable progress in woodland management was achieved through the Clarke-McNary Act of 1924. Since then, 39 states have provided for forest extension work through the various state agricultural colleges to assist in establishing, improving, and renewing woodlots, shelterbelts, windbreaks, and other forest growth, and in marketing or cutting the products. Forestry work with the 4-H Clubs has been effective and promises much for the future of woodlot forestry.

In effect, many farm woodlands are already managed on a sustained yield basis. A woodlot in northern New Jersey has supplied one family for six generations with a regular source of fuelwood, posts, and farm timbers, and the forest was generally maintained in excellent condition.

\section{PRINCIPAL DIFFICULTIES AND DETERRENTS TO THE PRACTICE OF PRIVATE FORESTRY}

Many factors have tended to discourage or prevent the more rapid practice of forestry on private timber property. Among these may be mentioned the following: 
1. Taxation. The burdens of annual taxation have been adduced as a deterrent to the practice of forestry. As it requires many years for a tree crop to mature, the cumulative effects of the tax burden may operate adversely when a woodland owner contemplates a definite plan of management. Many states have enacted measures to relieve this burden. Deferred or low current taxes are paid until the crop is ready for cutting and then a yield tax is applied. Various forms of yield or crop tax have been applied with some degree of success. Indiana, Louisiana, Wisconsin, and Oregon have successful taxation laws in effect. In some states there is a tax on the cutting in order to pay for the conservation measures in effect. In many states, as in New York, advantage has not been taken of the yield tax principle as applied to plantations and young growth.

2. Long-Time Investment. The cumulative effect of interest charges, protection expenses, depreciation of improvements and other structures may be so large and burdensome that it may be difficult to hold forest properties over extended periods of time. This is an excellent argument in favor of state and federal ownership as contrasted with private ownership. Although the people pay taxes for the maintenance of our state and federal forests instead of the individuals assuming this responsibility, many lumber companies as in the Northwest have been forced to liquidate their timber investments because the carrying charges for interest as well as taxation and other overhead expenses have been too burdensome to carry, in spite of the purchase of these holdings at a relatively low stumpage value.

3. Hazards of Fire or Pest Injury. In some regions, the danger of loss by fire is exceedingly serious and the costs of protection are very burdensome. In others, insect and fungus attacks have forced immediate cutting and liquidation. The hazards from these enemies of the forests have been a serious deterrent to the practice of forestry. It is possible that a system of forest fire insurance may be devised and that protective methods and organizations may be so improved as to minimize these damages and make the premium on insurance rates low enough to be attractive to private owners.

4. Low Prices for Forest Products. Many farmers and other forest owners have not received sufficiently high prices to justify any capital expenditure for forest improvements and maintenance such as planting, fire lines, and improvement cuttings. The market prices received for forest products are probably the greatest single factor in determining the intensity of forest practices in this country. High prices for forest products will greatly encourage the practice of for- 
estry. Conversely, low prices will not encourage the private individual to handle his forests on a sustained yield basis.

5. Unstable and Uncertain Markets. Separate from the low price factor is the fact that prices for forest products vary over a wide range. Owners should take advantage of the crest of price cycles if possible. Changing customs, the increasing introduction and use of substitutes, have made the prices for lumber and other forest products very unstable, uncertain, and unattractive at times. Under these conditions, it is impossible to forecast, accurately, prices to be expected for many of our products. It is likely that the high prices of 1920 may not be reached again for several years.

6. Public and Private Apathy and Ignorance. There has been a failure on the part of both federal and state governments properly to assist private owners to practice forestry. Too few laws are on our statute books to encourage forestry on private property. The lending power of the federal and state governments at low rates might well be put into effect as has been done to encourage other private industries and activities. 


\section{PART IV}

\section{EDUCATION AND RESEARCH}

\section{CHAPTER XIX \\ FORESTRY EDUCATION IN THE UNITED STATES}

\section{SCHOOLS OF FORESTRY}

Forestry education in this country began with the Biltmore Forest School established by Dr. Carl Schenck on the Vanderbilt estate, at Biltmore, North Carolina, in 1898. This was a forestry academy and some of the time was spent in traveling to various forest regions of this country and in Europe. The first professional collegiate school of forestry was established at Cornell University in 1898; it was discontinued in 1903 and re-established in 1910. The first permanently established school was located at Yale University in 1900.

This country has twenty-four professional schools of forestry. They generally offer four- or five-year courses of instruction. There are four professional forestry schools in Canada. Three schools, namely at Duke, Harvard, and Yale Universities, are solely on a graduate basis. Two state-supported schools offer semi-professional training at ranger schools, namely, at Wanakena, New York, and Mont Alto, Pennsylvania.

In addition to these schools of professional character, some courses in forestry are offered at a large number of agricultural, engineering, teachers, liberal arts, and other colleges, as well as at normal schools and junior colleges. Some schools give a pre-forestry training in fundamentals which lead directly to later attendance at schools of professional rank. At least some course of instruction in forestry, either of a professional or non-professional nature, is offered at over 95 colleges and universities.

The following list compiled by $\mathrm{H}$. H. Chapman shows the professional schools of forestry with their locations, departmental status, and degrees given. 


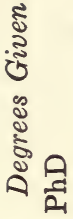

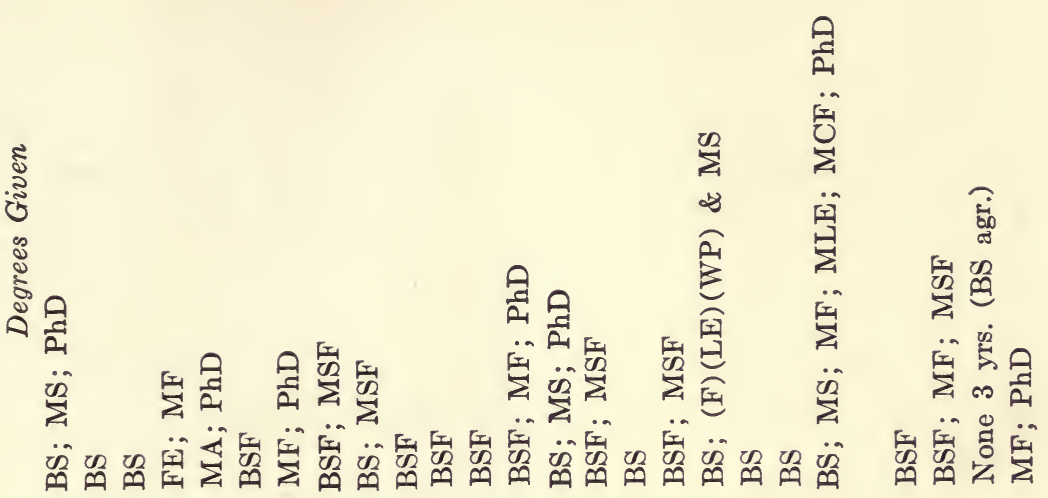

คั:

ڤँ

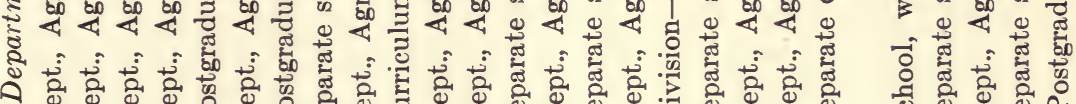

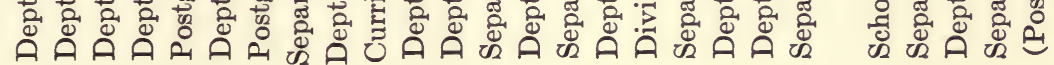

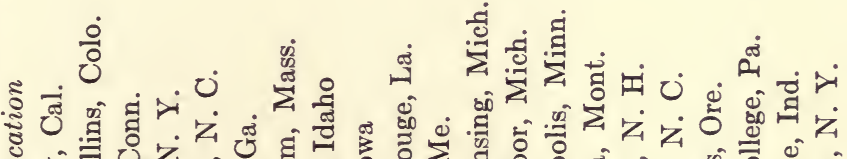

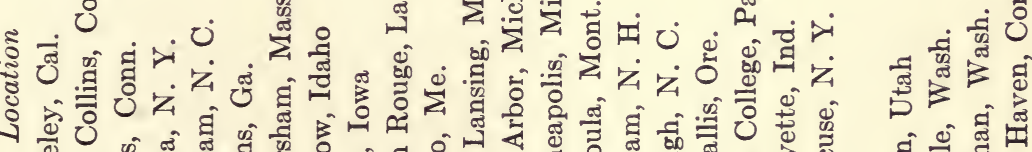

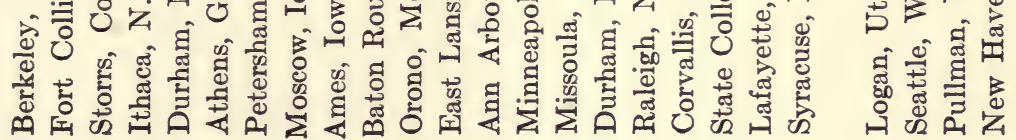

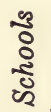

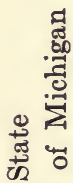

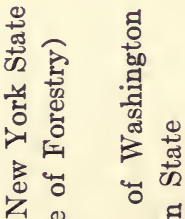

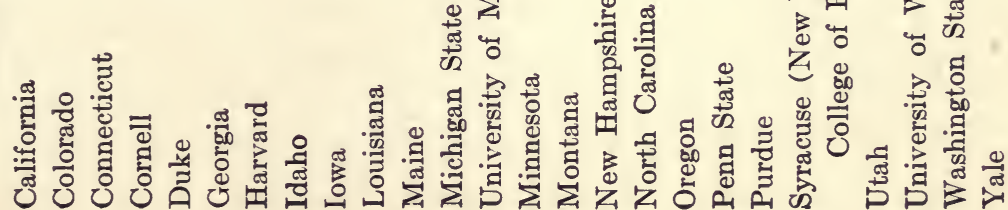




\section{WHAT FORESTRY GRADUATES DO*}

According to a study 'by Graves and Guise, approximately $80 \%$ of the graduates of the professional forestry schools are engaged in some phase of forestry occupations and activities. This compares favorably with other professions. However, forestry is still a relatively young profession. In many ways, occupations are expanding and new fields of activity are being developed. Graduates of forestry schools are employed in many more occupations than a decade or more ago. It is likely that the field of employment will expand with the broader conception of the province of forestry in the coming years.

According to the above authorities, the graduates of forestry schools are employed as follows:

Occupational Groups Percentage

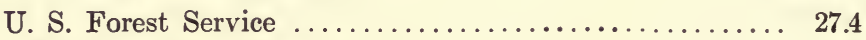

Other federal services $\ldots \ldots \ldots \ldots \ldots \ldots \ldots \ldots \ldots \ldots \ldots . \ldots \ldots$

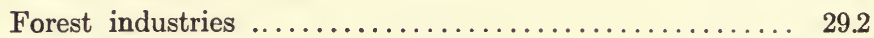

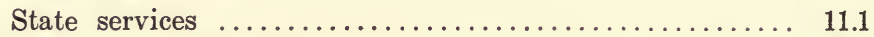

Educational institutions ..................... 9.3

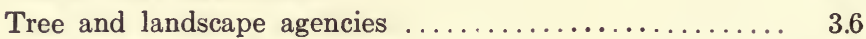

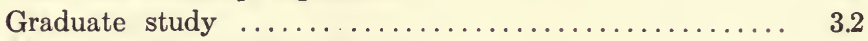

County and municipal services $\ldots \ldots \ldots \ldots \ldots \ldots \ldots \ldots . \quad 3.0$

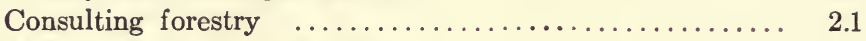

Forestry and trade associations $\ldots \ldots \ldots \ldots \ldots \ldots \ldots \ldots . \ldots \ldots$

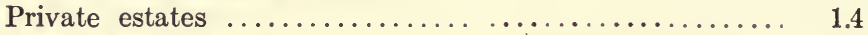

Foreign services $\ldots \ldots \ldots \ldots \ldots \ldots \ldots \ldots \ldots \ldots \ldots, 1.2$

Forest tree nurseries $\ldots \ldots \ldots \ldots \ldots \ldots \ldots \ldots \ldots \ldots \ldots \ldots$

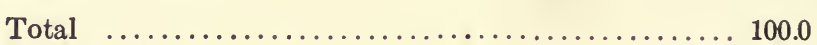

Annual earnings generally begin at $\$ 1800$ on graduation, and average incomes of men twenty years after graduation indicate salaries of $\$ 4700$. Those with advanced degrees such as the master's and doctor's generally receive higher salaries than those with the bachelor's degree. Those with the master's degree show average incomes of $\$ 5500$ twenty years after graduation.

The various emergency conservation and social employment measures inaugurated under President Franklin D. Roosevelt and discussed elsewhere have added very materially to the employment possibilities in forestry. In fact, there has been a great dearth of welltrained, experienced, and skilled foresters for the various technical

* For an elaboration of this subject see "Forestry Education" by Graves and Guise, Yale University Press, New Haven, Connecticut, 1932. 
positions that have been available. Enrolment in the forestry schools has reflected these increased opportunities. In nearly all the schools a substantial increase in the number of students has been noted since 1933. Many agricultural, teachers, engineering, and normal schools and junior colleges as well as those with the usual liberal arts curricula have offered electives or credit courses in forestry or forest conservation. 


\section{CHAPTER XX \\ FOREST RESEARCH}

\section{GENERAL}

Research may be described as the systematic study of certain phenomena by the experimental or investigative method. From a broad viewpoint, this nation is still in the infancy of knowledge regarding many aspects of forestry and forest products. We know relatively little of the silvicultural requirements of trees and the part they play in tree associations. We know comparatively little about wood and its multiple physical and chemical characteristics. Although trees, forests, and wood are commonplace things in our daily lives, and much study has been given them, an exact and scientific knowledge of their relationship to our national welfare is still relatively little understood.

Research has been conducted largely by our federal agencies, universities, colleges, and private industries and individuals. Large industrial groups, such as those engaged in the manufacture of automobiles, chemicals, clothing, iron and its many by-products, electric devices, and telephones, maintain large, well-equipped research departments. The efficient growth of forests and the adequate utilization of forest products are matters of such wide public concern that federal agencies have taken the leadership in forest research. In fact, from the very earliest organization of our federal forestry agencies, research has been one of the principal activities. For many years prior to the creation and organization of our National Forests, research was one of the most important aspects of the forestry movement. This continued until 1915, when the branch of research was established in the U. S. Foreign Service by the then chief forester, Henry S. Graves. The general expressed purpose was the greater efficiency of the three main departmental activities of the Forest Service, namely, those dealing with regulation, research, and extension. It became recognized that the great responsibility and objective of the Forest Service was to secure the complete use of all the forest lands of the country and of their products. 
The most important act which has provided for a definite policy of research was the McSweeney-McNary Forest Research Act of 1928. This specified what research was to be done, set up a definite program of field units, and outlined a ten-year financial program with certain restrictions, which includes a statement of the national need for research and the rate at which an efficient organization can be developed.

Hawley, in his book on Silviculture previously referred to, has pointed out that the experience of many years is necessary to develop adequate and efficient methods of silvicultural treatment of our forests, in relation to silvicultural systems as well as in thinning and cutting immature stands to improve the rate of growth, composition, and general condition of the stands.

Recently the demand for knowledge obtained through research has been greater than ever because of the large amount of man power available for work in the woods through the Civilian Conservation Corps (Emergency Conservation Work), the Tennessee Valley Authority, drought relief in the Middle West, chiefly in connection with the Shelterbelt Project, the marketing agreement with the naval stores producers in the South, the President's National Resources Board, the National Research Council, the special cabinet committee on rivers and waterways, the Soil Conservation Service, housing programs involving the use of lumber, and several other unemployment relief measures. The acquisition of submarginal lands and the broadening of the uses of lumber and other forest products have also intensified the importance of research.

When the Civilian Conservation Corps was organized in 1933, many thousands of men were available for improvement and cultural thinning in our young, ragged, and immature stands of timber. With almost 600,000 men available for all types of woods work in 1935, it became necessary to employ them on useful, constructive work in the woods. Some of the research problems had not been sufficiently studied to give fundamental facts necessary to put many of these young men to work in stand improvement activities. For example, in stands of young lodgepole pine timber containing from 5 to 20 thousand trees per acre, the question of the number of trees to eliminate and the spacing of trees left, was not readily answered. Adequately trained foresters, familiar with the results of research, were not available in sufficiently large numbers to meet many of these problems.

Briefly summarized, research seeks to obtain in the briefest possible space and time, and at the lowest possible expense, the funda- 
mental facts and knowledge that appear to be important in the field of forestry. The objectives may be stated as follows:

1. To establish markets for forest products and make it better possible for lumber and associated products to compete with other materials, especially those substitutes which have encroached, sometimes unfairly, for purposes where wood is the best and most inexpensive material.

2. To maintain the greatest productivity and the best use of forest land for timber growing.

3. To examine the effects of forests and other natural vegetative cover on the regulation of stream flow and the prevention of erosion and floods.

4. To attain the most productive use of forest ranges for the grazing of domestic animals consistent with timber growing, watershed protection, and native wild life.

5. To continue the forest in the best possible condition to meet the recreational needs of the nation.

6. To obtain information for the continuance of the forest as a center of game management and protection for wild life consistent with other uses and developments.

7. To evolve the best methods of economic and social life in forest communities.

Expressed concretely, the objectives of research are to make our forests render the widest and finest economic and social usefulness to our people.

\section{PRINCIPAL ACTIVITIES}

The principal work in forest research is done by the Forest Service through its various agencies, bureaus, and experiment stations. One of the outstanding examples of systematic and successful research is found at the U. S. Forest Products Laboratory at Madison, Wisconsin, which has eminently demonstrated its efficiency in increasing the knowledge of wood and its possible uses. As stated by Clapp in the Copeland Report, "Forest products are falling behind in the competition with other materials because, for one thing, less is known of their properties and how to use them. It is conceivable that forest products research can be made one of the chief competitive weapons to maintain an increased consumption and hence of an aggressive, constructive, plan-wise effort to make certain the use of forest land and to keep available for public use a material of high intrinsic value."

The Forest Service conducts 11 regional forest experiment stations, 
the headquarters of 6 of which are maintained at and in cooperation with universities. These stations are located as follows:

Allegheny Forest Experiment Station, Philadelphia, Pennsylvania. Appalachian Forest Experiment Station, Asheville, North Carolina.

California Forest and Range Experiment Station, Berkeley, California.

Central States Forest Experiment Station, Columbus, Ohio.

Intermountain Forest and Range Experiment Station, Ephraim, Utah.

Lake States Forest Experiment Station, St. Paul, Minnesota.

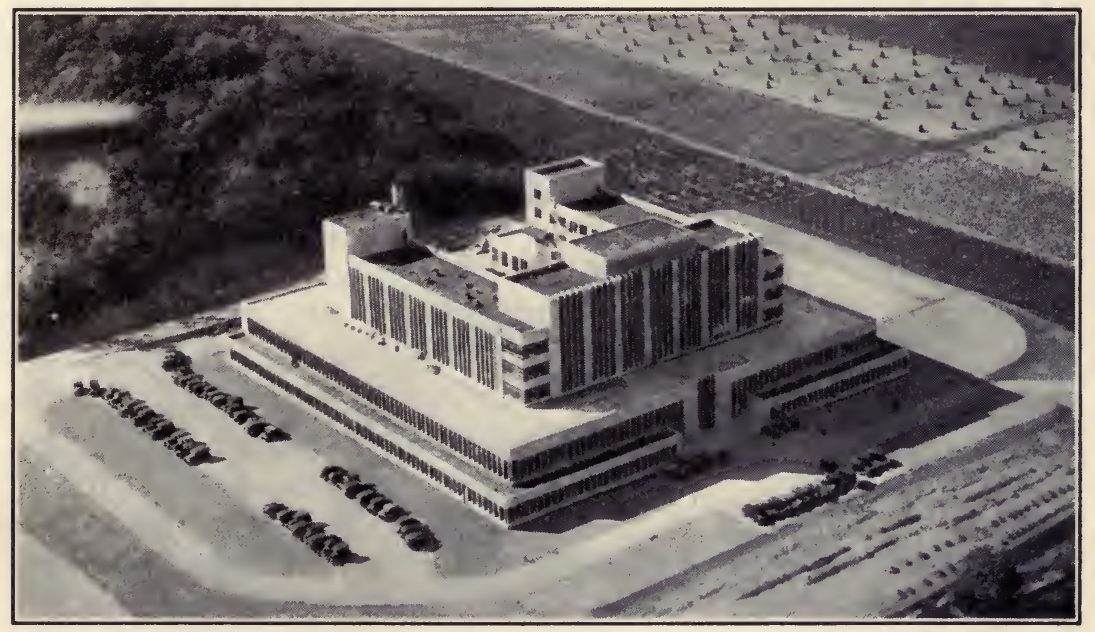

Fig. 116.-General view of U. S. Forest Products laboratory at Madison, Wisconsin, where a large staff of scientists and specialists are working on wood utilization problems.

Northeastern Forest Experiment Station, New Haven, Connecticut.

Northern Rocky Mountain Forest and Range Experiment Station, Missoula, Mont.

Pacific Northwest Forest Experiment Station, Portland, Oregon.

Southern Forest Experiment Station, New Orleans, Louisiana.

Southwestern Forest and Range Experiment Station, Tucson, Arizona.

Financial provision has also been made for the Central Rocky Mountain Station.

In recent years 29 experimental forests and 4 experimental ranges have been set aside by formal proclamation, and 24 natural areas 
have been established for investigative purposes. Additional experimental forests and natural areas are being selected. It is planned to have from 5 to 10 experimental forests in each forest region.

Appropriations made available for forest research during a recent fiscal year were over $21 / 2$ million dollars. Nearly 2 million dollars of this amount was available for current research expenditures and the balance for research investments, chiefly construction work, equipment, and acquisition of land. The chief divisions of experimental work in the Forest Service in order of importance from the viewpoint of appropriations are:

1. Forest products.

2. Forest management.

3. Forest survey.

4. Range investigations.

5. Watershed protection.

6. Forest economics.

7. Forest taxation and insurance.

The chief studies in the field of forest products which have to do with the more efficient utilization of forest crops are the use of lumber and wood in the building field, selective logging, studies of the prevention of sap stain on lumber, the use of lumber for cooperage, timber preservation, painting, better seasoning and kiln-drying practices, and improvements in the manufacture of pulp and paper from wood. In the field of forest management, studies are being made of cutting methods, slash disposal, fire control, silviculture and naval stores research, tree planting, problems in the prairie states, and improved nursery and reforestation practices. Watershed protection and forest influence investigations are conducted in connection with flood and associated problems in southern California, the Boise River watershed, the Appalachian Mountains, and in many other parts of the country. Range investigations are devoted to artificial reseeding problems, studies of grazing capacities and time of use on special types of ranges, control of rodents, and the general improvement of range conditions. In the field of forest economics, dependable data are being sought by public administrators, economists, and industrialists. This includes the study of tax delinquencies in many sections of the country, the relation of improved logging methods to sound timber management plans, time and cost studies on logging operations to improve the technique, forest fire insurance for the ponderosa pine and redwood regions of California, and a study of stumpage and log prices. Within the general field of forest economics, the nation-wide 
forest survey is being conducted. This includes an inventery of forest land and timber, an appraisal of present and potential growth, a study of requirements, and the interpretation of them in relation to each other and to other economic factors as a basis for forest policies and programs. The field work has been largely completed in the Pacific Northwest and is being actively conducted in the South and the Lake States where 120 million acres and 55 million acres respectively have been covered. The study of the fundamental research phases of forest taxation is completed.

Active studies are also being conducted by the various State Forest services as well as other governmental agencies. At several schools of forestry, some of the faculty members devote all or part of their time to research. Some states and schools have established very successful research stations, such as at Cloquet, Minnesota; Mont Alto, Pennsylvania; the Yale Forests in Connecticut and New Hampshire; the Duke Forest in North Carolina; the Harvard Forest, at Petersham, Massachusetts; the Arnot Forest in connection with Cornell University; the Pack Demonstration Forests in New York and Washington; and the Bates Forest in Maine. They are conducting research in several phases of forestry, particularly as applied to local and regional problems. Many private studies have been conducted by some of the large lumber companies, frequently in cooperation with state or federal agencies. Among these may be mentioned those at Urania and Bogalusa, Louisiana, northern Idaho, and in many sections of the West and Northeast on problems of forest management or utilization, especially in connection with selective logging, reforestation, fire control, and improved utilization practices.

Several of the schools of forestry have established laboratories in kiln-drying, timber preservation, timber testing, and pulp and paper manufacture, as a part of their school activities, both for research as well as for educational purposes. 


\section{PART V}

\section{FORESTRY IN THE NEW GOVERNMENTAL PROGRAMS}

\section{CHAPTER XXI}

\section{GENERAL}

Shortly after his inauguration on March 4, 1933, President Franklin D. Roosevelt began the formulation and organization of many important conservation programs which have immeasurably advanced the cause of forestry throughout the country and have generally enjoyed widespread public approval. Many of these programs are directly connected with the unempioyment relief situation to fit the economic requirements of the time. Social relief has been combined with the development and expansion of our forest resources. These have succeeded definitely in relieving the serious unemployment situation and also have contributed in a very substantial way to the upbuilding, development, and extension of our forest resources. These administrative enactments under presidential guidance described later have already resulted in the following improvements of our forest conditions generally.

1. Increased stimulus to reforestation by planting millions of trees on submarginal and abandoned farmlands, burned, idle, and eroded areas in National and State Forests as well as on privately owned land under the guidance of or in cooperation with federal, state, and local agencies. Planting on state and federal lands amounted to 164 million trees in 1934.

2. The further reduction of serious hazards in our forests from fire damage as well as serious depredation from tree insects and diseases.

3. The improvement of the general growing conditions of our young and immature stands of timber, chiefly in our National and State Forests, by weeding, thinning, improvement cuttings, and pruning.

4. A marked increase in the areas of National and State Forests as well as in State Parks as a result of the interest in our public 
forests stimulated both directly and indirectly by presidential or legislative enactments.

5. The integration of social and economic phases of forestry activities with industrial, power, and other developments, as in the Tennessee Valley Authority and elsewhere.

6 . The improvement of conditions for the management and continuance of wild life resulting in better hunting and fishing facilities. This has been accomplished by stream improvements, the construction of many hundreds of fish dams, and the increase in facilities for rearing and distributing trout and other fish and game birds.

7. The betterment of facilities for recreational use of the forests. Increased leisure time combined with the automobile and good roads have given new impetus and significance to forests for healthy recreational and outdoor enjoyment of many kinds. The Civilian Conservation Corps program in the National Forests, National Parks, as well as in State Forests and Parks has made a notable contribution in this direction.

8. The opening of the forests by means of roads, trails, and bridges, for better fire protection and recreational development, and the increased values of forest products by making our woodlands more accessible and available and therefore more valuable.

These are the outstanding benefits derived from this enlarged forestry program. Many more incidental and indirect benefits may be cited. This enumeration could very well include many more improvements in our general forest conditions which have inured directly to the greater prosperity, welfare, and happiness of the American people.

\section{ENLARGED NATIONAL FOREST ACQUISITION PROGRAM}

The Weeks Law of 1911, mentioned previously, provided for the first purchase of eastern National Forests on the watersheds of navigable streams. This program was greatly strengthened and enlarged by the Clarke-McNary Act of 1924. For many years, however, the federal appropriations for the acquisition of these eastern National Forests has proceeded at the rate of about 2 million dollars annually. In July, 1933, President Roosevelt allocated 20 million dollars from the Emergency Conservation Work funds for additional purchases of $\mathrm{Na}$ tional Forests. In December, 1934, he allocated 10 million dollars additional from the same funds and in 1935, several million dollars from general funds. This means that the system of National Forests in the East, South, and Lake States has been greatly enlarged. The total areas purchased are about 12 million acres. 
There are 69 established purchase areas-that is, locations in which the U. S. Forest Service is planning to extend and consolidate its National Forest properties. Among these, 2 are in New England, 14 in the northern Lake States, 16 in the southern Appalachian region, 24 in the southern pine region, 11 in the Ozark section of Missouri and Arkansas and the Central Mississippi region, and 2 in Puerto Rico. Some of the largest and most important areas acquired have been in southern Missouri, east Texas, central Louisiana, northern and southern Mississippi, southern Illinois, eastern Kentucky, South Carolina, North Carolina, northern Michigan, northern Wisconsin, and northern Minnesota. 


\section{CHAPTER XXII}

\section{EMERGENCY CONSERVATION WORK}

\section{CIVILIAN CONSERVATION CORPS}

The Civilian Conservation Corps is a combined social relief and conservation program. It was primarily designed to relieve distress

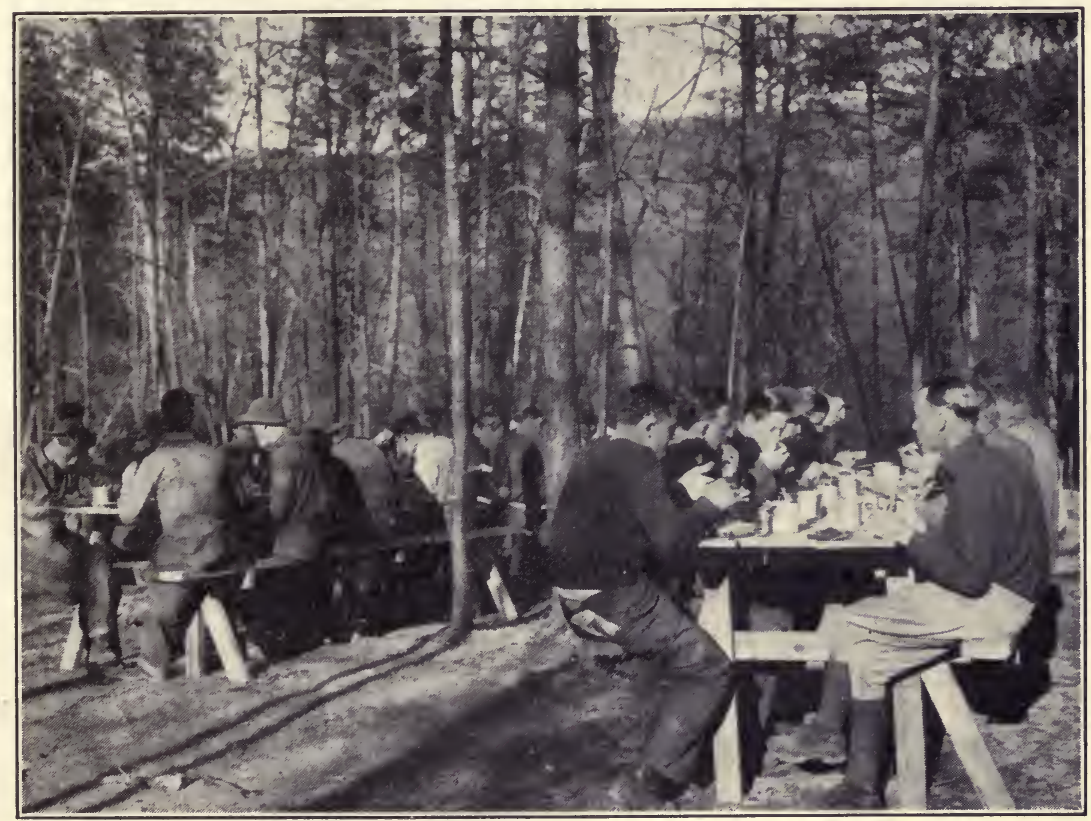

FIG. 117.-Meal time at the first Civilian Conservation Corps camp, known as Camp Roosevelt, established in the George Washington National Forest in Virginia in April, 1933.

and unemployment. It constitutes the greatest forward impetus that forest conservation has received since the early years of the present century, from President Theodore Roosevelt and his chief forester, Gifford Pinchot. It has provided a great opportunity to accomplish many things in the woods that foresters have wanted to do for years. 
This program was announced by President Franklin D. Roosevelt within a few days after his inauguration, and was approved on March 31, 1933. Within three weeks the first camp was established in Virginia. By July 1, 1933, about 310,000 young men were enlisted-the largest peace-time enrolment in the history of the country -more than served in the Spanish-American War. The rate of recruitment exceeded the busiest days of the World War. Over 1,200,000 men have been benefited by service in the work. In April, 1935, it was decided to expand the program to 1937 so that there would be about 600,000 men in about 2900 camps.

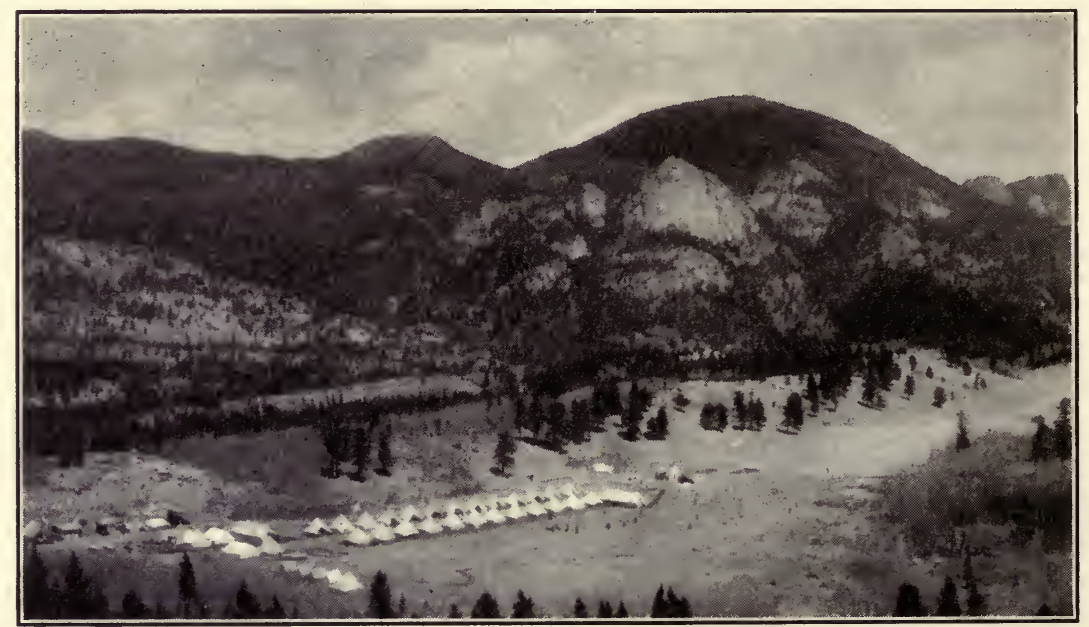

Fia. 118.-Civilian Conservation Corps camp located in the Rocky Mountain National Park near Estes Park, Colorado. At the left are the army officers' and foresters' quarters, cooking and mess tent, and on the right are the pyramidal tents, each holding 6 men, with recreation tent on the extreme right.

Four federal departments participated in the program, as follows: the Labor Department selected the men as to age and need for work from the unemployment relief rolls of each locality; the War Department enrolled the men, conditioned them in the various posts, transported them, and erected and operated the forestry camps; the Agriculture and Interior Departments were charged with the responsibility for the work done in the woods, chiefly through the Forest Service of the former department and the National Park Service and the Indian Forest Service of the latter. Approximately $80 \%$ of the camps were located on federal properties, and these two departments were charged, with the responsibility for approximately $98 \%$ of the projects. Most of the camps were located in National Forests. A 
smaller number were located in State Forests, National Parks, State Parks, and Indian Reservations. Several were assigned to the Tennessee Valley Authority, Soil Conservation Service, and other federal projects for work in connection with them.

The principal features of the program may be summarized as follows:

1. It was primarily designed for unmarried men, 18 to 25 years of age, who had dependents at home.

2. The men were fed, housed, and clothed by the government and paid $\$ 30$ per month, of which $\$ 25$ was allocated to dependents at hoine -parents, brothers, sisters, etc.

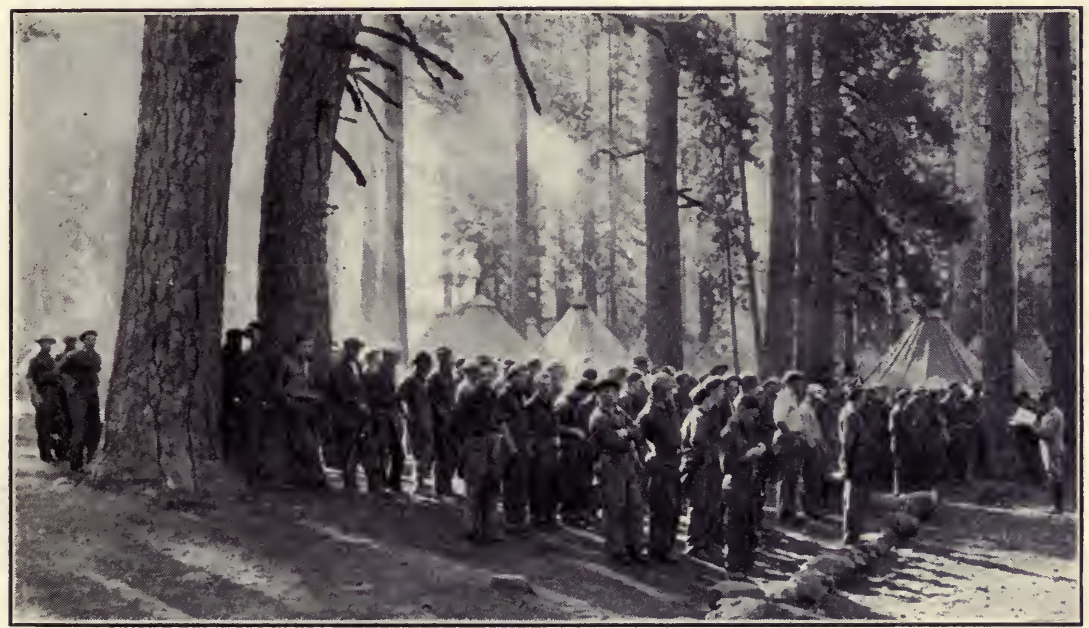

Fis. 119.-Morning roll call in one of the Civilian Conservation Corps camps near Maupin, Oregon. This is located in the heart of a ponderosa pine stand in the Cascade Mountains. About 200 men were assigned to each camp. An army officer served as Camp Commander and the Forestry Superintendent assisted by several forestry foremen had charge of the work in the woods.

3. The enrolment was predicated on a population basis so that men were selected chiefly from the larger urban centers. They were, therefore, largely city boys, untrained in the work of the woods and unskilled in the use of woods tools like the axe, cross-cut saw, peavy, cant hook, and bulldozer.

4. To each camp 200 men were assigned. The camps were operated by camp commanders, generally army captains, and a few assistants. The forestry work was supervised and directed by a camp superintendent and generally from 8 to 15 forestry foremen. 
5. The men were expected to be engaged a minimum of 8 hours a day including lunch, or 40 hours a week. Saturdays were given over to camp clean-up and miscellaneous duties. Often from 1 to 3 hours were required in going from the camp to the work and back.

6. No army discipline or drilling with rifles, that is, no militarization, was permitted. They were civilian rather than military camps.

7. The men generally lived in barrack-type buildings in winter and frequently tent camps in summer, depending upon weather and climatic conditions. The chief buildings were the mess and cook halls,

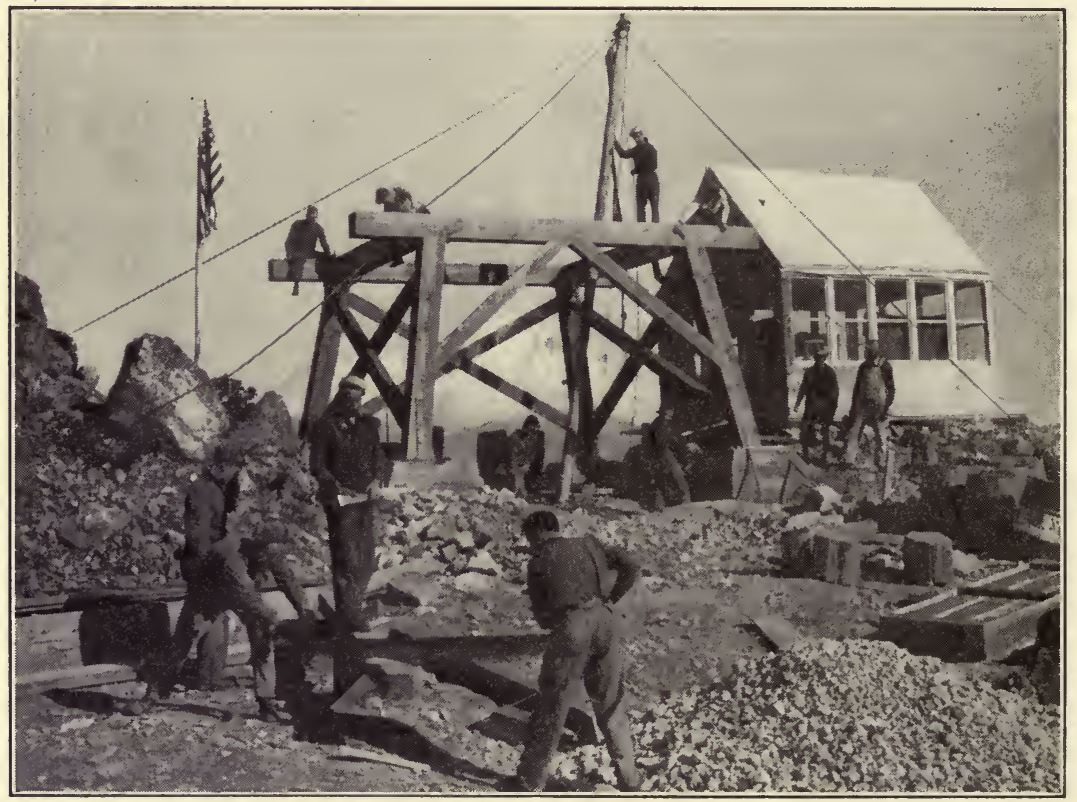

Fig. 120.-Building a lookout on Mt. Bradley in the Shasta National Forest, California. Mt. Shasta in the background.

a recreation hall, tool house, and sleeping quarters for the army officers, forestry supervisors, and the enrolled men.

8. Only about 32 to 41 cents per man per day was allocated for food supplies. This, however, did not include the cost of transportation. The men generally gained from 10 to 25 pounds apiece during the 6-month enrolment period. Medical attention was available in all camps practically every day.

9. The number of camps varied from about 1450 to 1700 from 1933 to 1935 , when they were nearly doubled. They were located in every state in the union but chiefly in the heavily forested regions of 
the South, the Northwest, the Lake States, the Rocky Mountains, the Appalachian Mountains, and the Northeast. During the first period of 6 months, California had 168 camps, chiefly in National Forests, Pennsylvania had 88 camps principally in State Forests, and Idaho had 96 camps, principally in National Forests. Some states had only two or three camps.

The results of the program have been most beneficial, for the moral and physical as well as the mental well-being of the men. It has also greatly relieved distress in many hundreds of thousands of American homes. Moreover, it has effectively assisted industry in its economic recovery by the purchase of over 16,000 automotive units, chiefly small motor trucks, at a cost of over $\$ 12,000,000$. Over $200,000,000$ b.f. of lumber have been purchased for the erection of barracks and other camp structures. About 2,000,000 feet of water pipe, $4,500,000$ pairs of shoes, 80,000 fire extinguishers, 166,000 wash basins, 600,000 folding cots, 400,000 brooms and many miscellaneous items were purchased in order to maintain these camps. The railroads were benefited very materially by the transportation of many men. Since most of

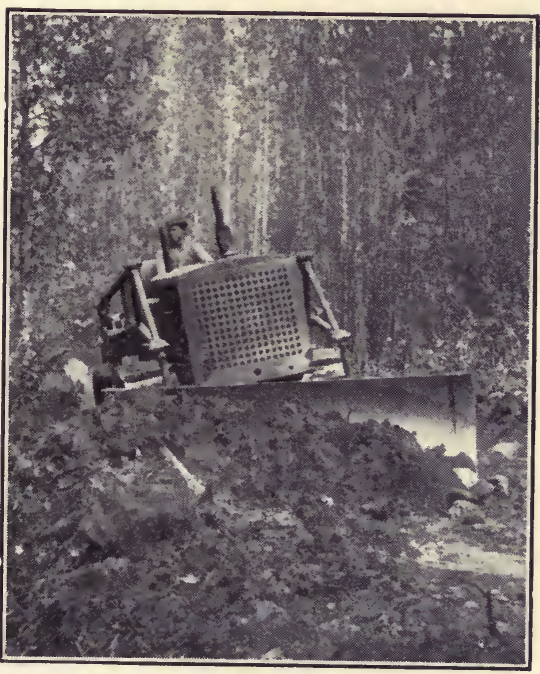

Frg. 121.-A Caterpillar Diesel 50 h.p. tractor building a road through the forest on the slopes of Mt. Hood in Oregon. This is known as a trail builder or bulldozer and does the work of approximately 150 men and several teams of horses. It will remove trees up to 14 " in diameter without previous cutting or preparation. Many roads are built with these tractors to make the forest more accessible for fire protection, to permit recreationists to enjoy the forest and to make it possible to transport the timber products more cheaply to market. the men were enrolled in the East and the work was largely in the South and West many of them were transported long distances. Approximately 24,000 out of a total of about 30,000 men in New York State were transported to the Rocky Mountain and the Pacific Coast States during the first enrolment.

The greatest single achievement, however, has been in the upbuilding and development of good citizenship in a great army of young American men. Although trained and educated for life, these boys 
had little if any opportunity to obtain positions. The potentialities, therefore, for good or bad were enormous. The program has very materially benefited the morale, the sense of responsibility, initiative, and enterprise of large numbers of future American citizens.

The program has also advanced forest conservation from 20 to 50 years ahead of the normal progress. The work of the boys in the camps and the accomplishments may be summarized briefly as follows:

1. Probably the most important work was the improvement of the existing stands of timber by cultural thinning and the removal of over-

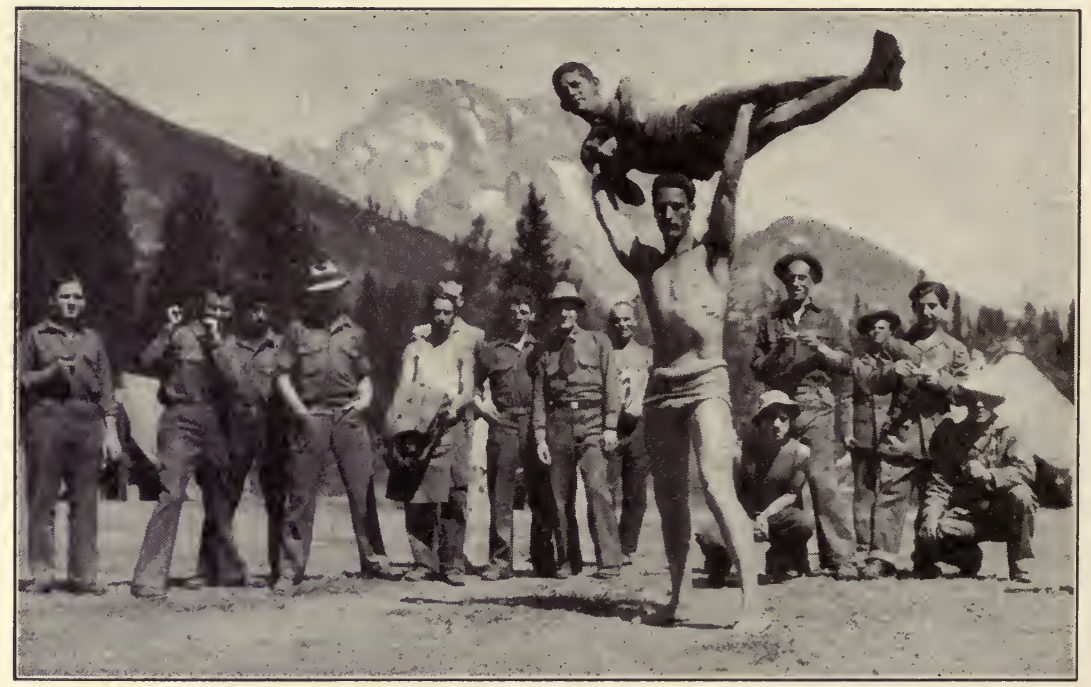

Fra. 122.-Play time at one of the Civilian Conservation Corps camps in western Wyoming. The forestry work hardened the muscles of city boys, who were untrained and unskilled in the ways and work of the woods. They generally gained several pounds in weight apiece. The improved morale and training for better citizenship were outstanding features of these camps. The men have advanced the cause of forestry several years ahead of its past normal progress.

mature, diseased and insect-infested trees. Over 4,000,000 acres have been treated in this fashion, chiefly in the southern states, the Lake States, and the Northwest.

2. The renewal of forest cover by planting many millions of trees and the establishment of many tree nurseries have been other notable features. Over $3,000,000$ acres have been planted to young trees, and over 560,000 pounds of tree seeds have been collected for reforestation projects. 
3. The elimination or diminution of forest destruction by forest pests, such as the white pine blister rust, the white pine weevil, and the Dutch elm disease. Over 5,000,000 acres have been treated for insect and disease control in addition to the protective measures as indicated in connection with cultural thinning.

4. Reduction of serious fire hazards by the removal and elimination of inflammable material along the highways and trails and on old logging operations. The cleaning up to reduce fire risks has been one

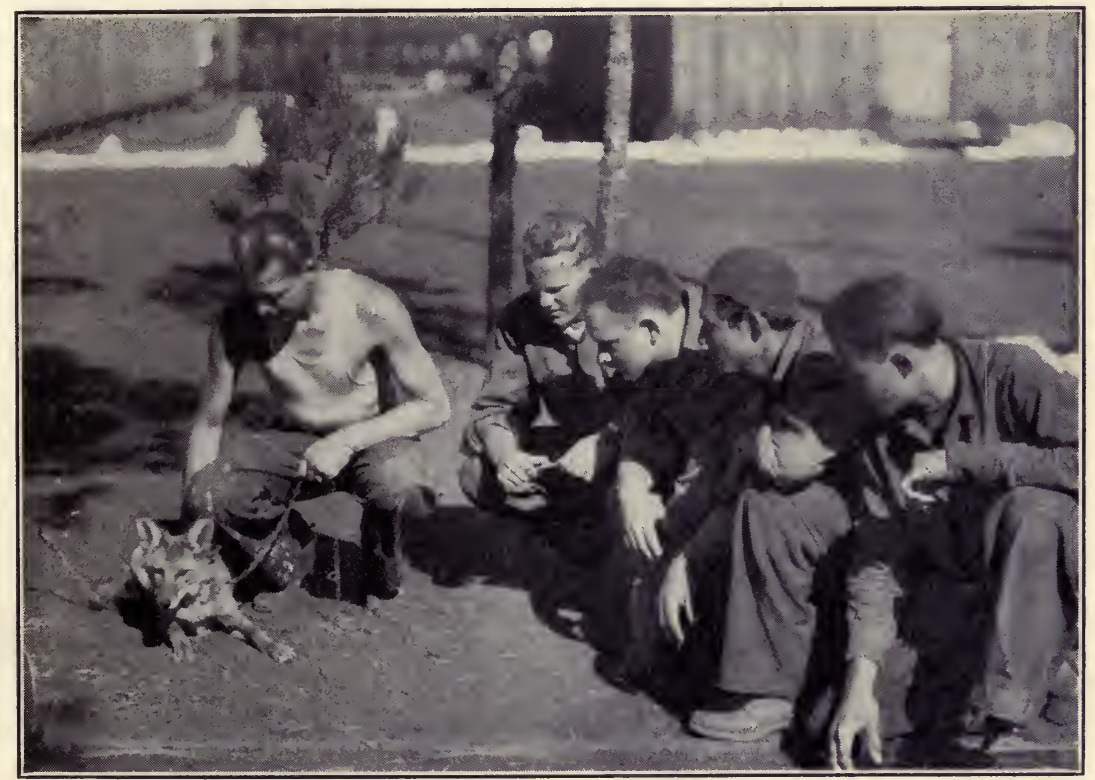

Fig. 123.-Members of a Civilian Conservation Corps camp with their coyote pup mascot. The boys were encouraged to protect wild life and become interested in the proper care, protection and management of game and fish life in our National Forests, and State Forests and Parks. The coyote is a predatory animal and together with mountain lions and wolves are generally discouraged on public forests throughout the West.

of the most important phases of the work. The construction of fire towers, telephone lines, and firebreaks, and the felling of snags (standing dead trees) have contributed in a most important way to a solution of our fire problem. Several million acres have been treated and cleaned up, many miles of roadsides have been made safe from fire, over 35,000 miles of telephone lines have been built, and over 1000 lookout towers have been constructed at high elevations.

5. The construction of forest highways and trails in order to remove 
and transport forest products and to make these forests accessible for recreational purposes has been of vast importance. Forest roads and trails assist in the system of fire prevention and control. More than 50,000 miles of these highways have been built, and many thousands of foot and horse trails have been constructed.

6 . The reduction or control of soil erosion by building dams, planting trees and other plants, and similar methods. Over 1,000,000 dams have been built, thus benefiting over 1,500,000 acres. In the Tennessee River Valley and along the Mississippi and Ohio Rivers, and in many other sections of the country, the control of serious erosion in both our agricultural and forested districts is of great importance.

7. The improvement of conditions for wild animals, birds, and fish. Over 3000 fish dams have been built. Provisions for our wild life have been a recognized part of the program.

8. Rodent control. This is conducted principally in National Forest areas in the West to improve grazing conditions. Over 10,000,000 acres have been treated in this way. Ground squirrels, gophers, and other rodents have done a tremendous amount of damage on many grazing areas in the West.

In addition, many roads and trails have been landscaped; many corrals and forest structures, such as rangers' cabins, tool houses for fire protection, and lookout cabins, have been built; many springs have been developed to assist the grazing of sheep and cattle; six airplane landing fields have been constructed; and even coal mine fires have been combated. 


\section{CHAPTER XXIII}

\section{THE TENNESSEE VALLEY AUTHORITY}

The Tennessee Valley Authority was created by act of Congress on May 18, 1933, and is managed by a board of three directors appointed by the President with the approval of the Senate. As expressed by President Roosevelt:

The continued idleness of a great national investment (the Muscle Shoals development) in the Tennessee Valley leads me to ask Congress for legislation

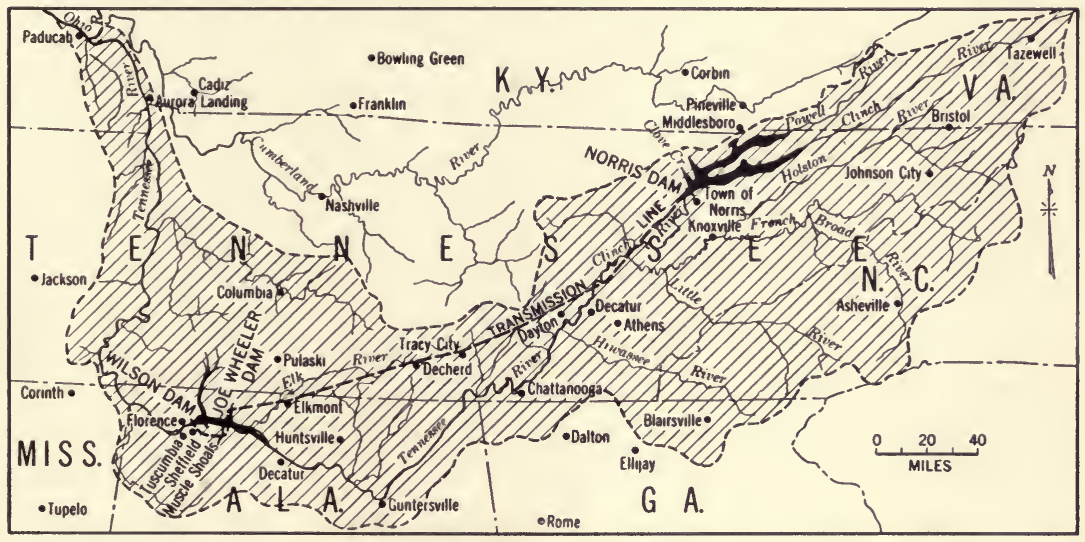

FIG. 124.-General outline of the basin of the Tennessee River showing the sites of the Wilson, Norris and Joe Wheeler dams. The shaded areas lie within the drainage basin of the Tennessee River, which is located in parts of 7 states.

necessary to enlist this project in the service of the people. It is clear that the Muscle Shoals development is but a small part of the potential public usefulness of the entire Tennessee River, such as, if envisioned in its entirety, transcends mere power development; it enters the wide fields of flood control, soil erosion, afforestation, elimination from agricultural use of marginal lands, and distribution and diversification of industry.

The Authority is clothed with the power of government but possessed of the flexibility and initiative of private enterprise. It is charged with the broadest duty of planning for the proper use, conservation, and development of the natural resources of the Tennessee 
River drainage basin and its adjoining territory for the general social and economic welfare of the nation. In $1933, \$ 50,000,000$ was authorized for the project which embraces more than 40,000 square miles and encompasses the drainage area of the Tennessee River and its tributaries in Tennessee and portions of six other states, namely, Virginia, North Carolina, Georgia, Alabama, Mississippi, and Kentucky. More than 2,000,000 people live within this area, and about $6,000,000$ people are in the immediate adjoining sphere of influence.

The project includes various purposes of development, but one of the principal branches of the work is the Division of Forestry. The principal objective of this division is the development and maintenance of proper protection forests. This includes all those phases that have to do with the control of watersheds, principally the prevention of soil erosion, the reforestation of eroded and gullied areas and submar. ginal agricultural lands, forest engineering, and the study of the steps necessary to put into operation the proposed control of water and streams before they flow into the larger rivers.

The foresters in the Division of Forestry have been described as vegetative engineers because to a large extent the chief objective is in the direction of protecting the navigation and water flow for the large engineering structures in the streams of the Tennessee basin. The chief emphasis is therefore placed upon protection forestry.

The Division is chiefly concerned with the problem of soil erosion throughout the Tennessee Valley because this represents one of the major difficulties that have to be faced in assuring proper protection. There is, therefore, a direct interest in the submarginal and abandoned farm lands. This interest is centered principally in the critical erosion areas rather than in the large tracts of mountain forest lands which are not being eroded to any appreciable extent. The area of eroded lands has been estimated at 500,000 acres in the upper valley area above Chattanooga and 300,000 acres below, or a total of 800,000 acres.

The protection of the Tennessee Valley watersheds makes it obligatory for the forestry officials to concern themselves with the adequate care and management of these mountain forest areas, and for this reason efforts are made to stimulate the further acquisition and development of National Forests on the westerly slopes of the southern Appalachian Mountains as well as in such State Forests, National Forests, National Parks, and State Parks as may occur on the smaller areas in the mountain forests, principally on the Cumberland and nearby ranges. 
The policy of the Forestry Division is eventually to place a very large share of the mountain forest lands of the Tennessee Valley under organized forest management, either by the U. S. Forest Service, the Tennessee Valley Authority, the National Park Service, or the State Forest services. Considerable progress has already been made in this direction. Under the $\$ 30,000,000$ made available for increased purchase of National Forests, considerable areas are being acquired in the Tennessee Valley drainage area, particularly along the headwaters

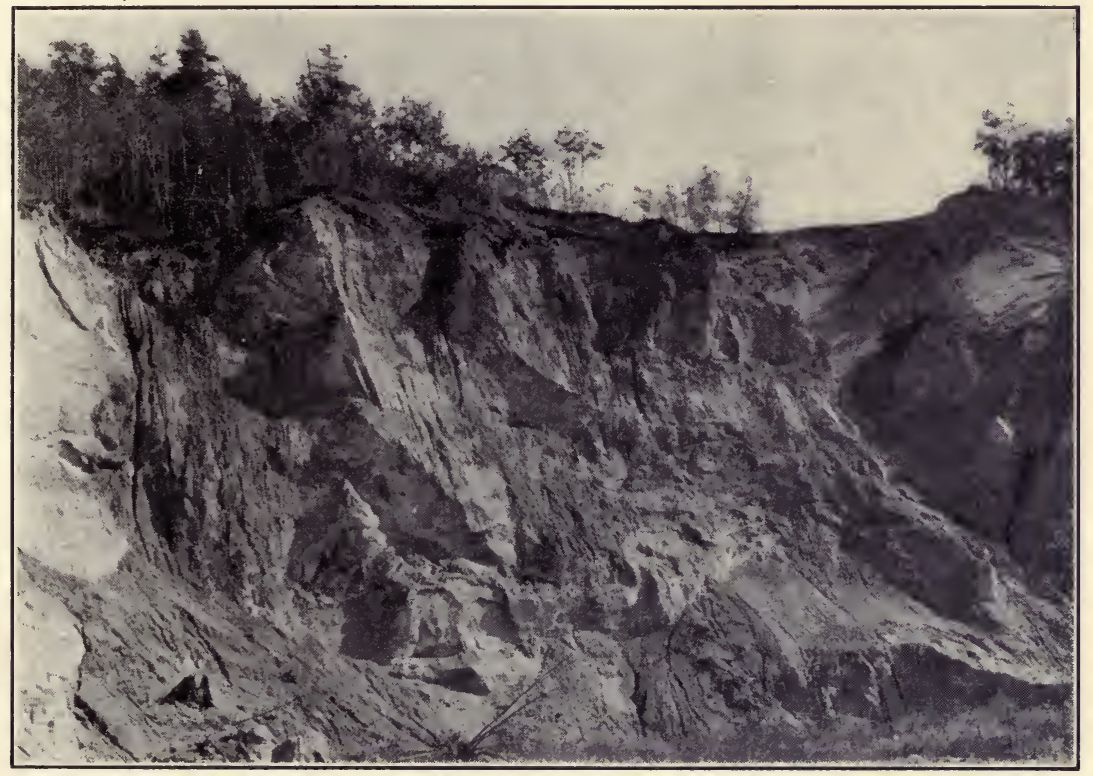

Fig. 125.-An example of the advanced stages of erosion found in many parts of the country, especially in the Southeast, South and the Central States. Erosion control by tree planting is an important part of the work of the Tennessee Valley. Authority.

of the mountain streams and to consolidate National Forests already purchased.

The possibility of developing municipal and town forests throughout the valley is also being given considerable attention.

The area immediately adjoining and surrounding the lakes will be gradually allocated to the Division of Forestry for administration, particularly where they all may be under forest cover. Detailed plans have already been made for the area about Norris Lake and other power lakes. These areas, however, do not compare in size with the National Forest districts. The management of these forest properties 
about these lakes will be on a much more intensive basis than on either the National or State forests because the erosion problem is much more critical and it is necessary that the greatest possible protection be afforded the slopes and shores adjoining these lakes.

In the administration of lands, the Division of Forestry is developing all possible resources, such as wild life and fisheries, and in some instances grazing in fenced pastures may be leased. The fundamental purpose is to develop all the possible uses of the Tennessee Valley forests that will provide employment for the people and thus tend to stabilize rural living conditions as far as possible. Considerable attention is given to a plan of Forest Workers Holdings, somewhat along the lines of the British Forestry Commission. In this way it is hoped to create and develop the greatest possible social uses of the forest land.

There are approximately $6,000,000$ acres of farm woodlands within the confines of the valley. The Division of Forestry plans to cooperate with the extension foresters of the various valley states and assist them in woodlot extension activities.

It is planned to acquire some of the most critically eroded areas, particularly those concerned with the submarginal and frequently abandoned lands. Approximately 15,000 acres had been purchased by April 1, 1935. These areas will be administered as protection forests by the Division.

In 1933, twenty-five Civilian Conservation Corps camps were assigned to the Tennessee Valley Authority. This number has varied from one enrolment period to another so that between 3800 and 5000 men have been available for forestry operations. Thirteen of these camps are now located in Tennessee, four in Virginia, and two in Alabama. Requests for additional camps have been made for the fifth enrolment period. Up to $1935,7,750,000$ trees were planted on erosion control areas by the men of these camps, and several million trees will be planted each year.

Three tree nurseries have been established; two for forest trees, and one for tree crops.

One of the forest tree nurseries has been established near Clinton and is operated with the help of Civilian Conservation Corps workers. Seeds for the nurseries are gathered by the same workers. They shake them out of black locust trees, cut off the cones of pines, and pick the seeds from red cedar trees. The other forest nursery is located at Wilson Dam, Alabama, and has an ultimate capacity of about $15,000,000$ trees.

The principal trees grown in the two forest tree nurseries for re- 
forestation, chiefly for erosion control, are such pioneer species as black locust, shortleaf and Virginia pines, and red cedar. The "climax" species such as yellow poplar, various oaks, Asiatic chestnut, and black walnut are either seed spotted or else planted in mixture with the pioneer species so that a mixed stand will be the final result.

A very interesting phase of work in the Forestry Division is the development of tree crops. This includes the growing, development, and establishment of all the best-known varieties of nut trees and other crop trees, such as honey locust, persimmon, Asiatic chestnuts, and pawpaw. The entire southern part of this country and even foreign sources are being searched for the best available species. The tree crop nursery of the Division of Forestry not only seeks to grow trees from seeds and nuts, but also to specialize in grafting and budding species and in breeding trees of all kinds which will be suitable for tree crops. These trees will provide food for wild life, cattle, hogs, sheep, and men. Two large forest tree nurseries are engaged in planting stock for general reforestation purposes. Species grafted and budded for superior varieties are black walnuts, wild black cherry, filberts, pecans, hickories, persimmons, blight-resistant Asiatic chestnuts, pawpaw, and similar crop trees. They are being planted concurrently with the soil erosion and reforestation projects. A particularly interesting development is the breeding of plants for food for birds and other forms of wild life.

The Division of Forestry conducts an educational program both in the Civilian Conservation Corps camps and at the town of Norris, and in other centers about the Norris Lake. The project includes the giving of lectures, presentations of exhibits, and showing of motion pictures and lantern slides and even the teaching of the principles of grazing and elementary forestry. Plans are under way for the development of woodsmen training courses for men who will work on a part-time basis on lands owned or controlled by the Authority.

The need for both intensive and extensive forest land classification and forest planning is recognized in order to put into effect the above activities. Studies have been continued on land classification in four degrees of intensity in the Valley. First is the study on a very extensive scale of the forest and erosion conditions of the entire 28,000,000 acres included within the Valley. Automobiles, airplanes, aerial photographs, and field reconnaissance have enabled the officials to complete a large amount of this work. A study of second-degree intensity is that of land classification, forest needs, and erosion conditions in the Clinch-Powell River watershed extending above the Norris Dam into Virginia, an area of approximately $1,856,000$ acres. This study in- 
cludes not only soil erosion and general forest conditions but also the conditions of the inhabitants and their relationship to possible future forest development. The study of third-degree intensity is that of lands which are or will be owned immediately surrounding Norris Lake, totaling approximately 100,000 acres. On this area, an intensive detailed study has been made of such factors as forest cover, slopes, land use of both a present and potential nature, location of roads and trails, and of all other points of interest, and the information has been incorporated on a series of maps. This study is so thorough that it is quite comparable to the detailed maps used by European foresters in the intensive management of their forests. It is planned to use the data so obtained to set up a completely comprehensive forest economy on the Tennessee Valley Authority lands around Norris Lake, coordinating all natural resources, to be handled on a sustained yield basis, with permanent part-time and full-time forest workers living on or adjacent to the lands. A fourth and very intensive study has been made in cooperation with the geographers of the Authority in sampling the conditions found in one of the counties of eastern Tennessee. Under this plan, all lands are carefully examined on areas as small as five acres in extent. An effort is made to secure the most minute details to fit in and to be integrated with the other divisions of the larger plan. The objective is to create a complete land use program for the entire region. This fourth study is in counties where the forestry division activities are limited almost exclusively to farm woodlands and the smaller erosion control areas. 


\section{CHAPTER XXIV}

\section{THE SOIL CONSERVATION SERVICE}

The Soil Erosion Service was authorized under the National Industrial Recovery Act and was created by order of Secretary Harold L. Ickes, Public Works Administrator, in August, 1933, with an initial allocation of $\$ 5,000,000$ of PWA funds. Later, additional allocations of $\$ 15,000,000$ were made available for this Service which was operated under the Department of the Interior until April, 1935, when it was transferred to the Department of Agriculture and renamed the Soil Conservation Service.

The program of the Service represents the first attempt in the history of the nation to organize large and comprehensive erosion and flood-control projects in representative watersheds of the major agricultural regions. The plan for each project involves the coordination of necessary engineering, forestry, and cropping measures carried out conjointly as the character of the land and its condition may prescribe.

The fundamental objective of the Soil Conservation Service is to preserve the great agricultural wealth of the country from impoverishment and depletion through the washing away of the fertile top soil and the gullying which follows. Closely related to the subject of soil erosion are the problems of reservoir and stream silting and general flood control. Precipitation in the form of rainwater and snows should be retained as far as possible in the soil where it falls, instead of permitting it to enter the streams and add to their burden of soil débris for deposit on the rich bottomlands at lower levels and in the channels of navigable and other streams. More than 400 million tons * of suspended solid matter pass out of the mouth of the Mississippi River every year. In pursuit of these objectives, the major purpose of the Service is to establish soil erosion demonstrations on $a^{\text {. }}$ watershed basin in those regions where erosion is a critical factor in agriculture. Within its province is included all lands concerned with the drainage basins of selected watersheds.

* Enough top soil is lost annually in the Mississippi River basin to build 1250 farms of 160 acres each with a soil depth of 12 inches. 
There is an intimate relationship between soil cover and the likelihood of erosion. This means that forest, farm, and pasture lands are included within the general purview of the Service.

About 100,000,000 acres of the most fertile lands of the nation have been rendered essentially worthless by being stripped of their top soil by sheet erosion and by gullies. Approximately $75 \%$ of all the farm lands of the United States are located on slopes subject to erosion. The last stages of the erosion processes usually assume the form of

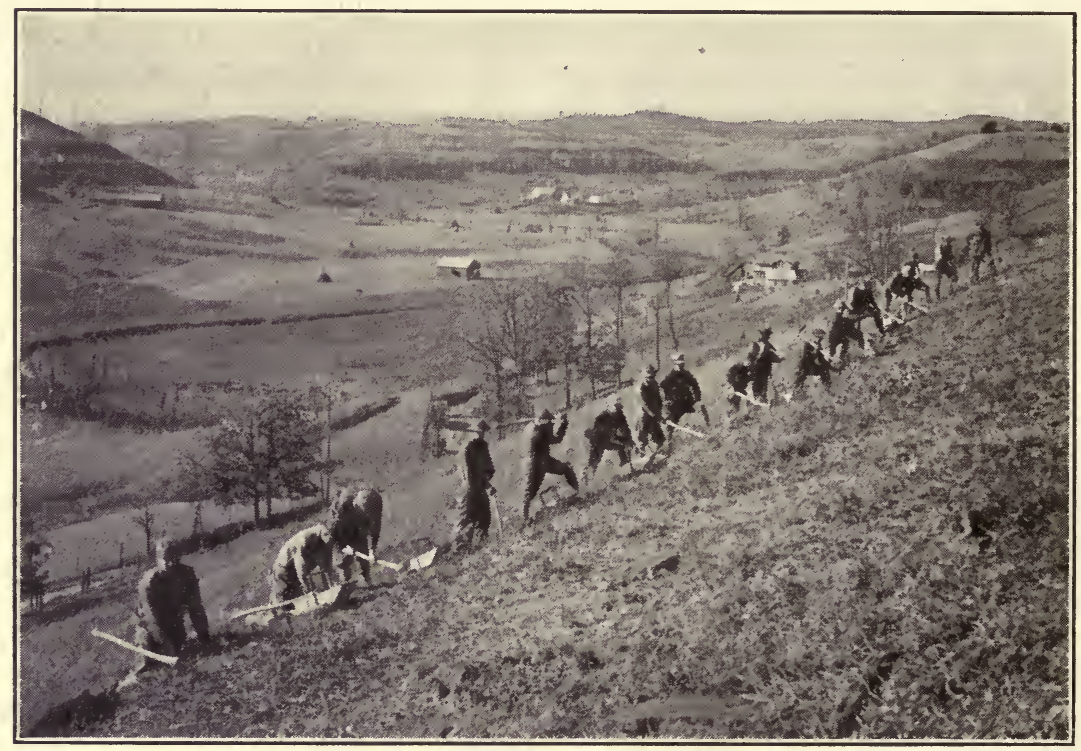

Fig. 126.-Civilian Conservation Corps boys planting trees on erosive slopes on Soil Conservation Service project in West Virginia. Trees not only keep these lands from erosion, but protect the lower, rich valleys from burial by poor soils. Photograph by Soil Conservation Service.

gullying. It is estimated that in addition to the 100,000,000 acres of formerly cultivated lands that have been practically ruined, an additional area of about $125,000,000$ acres still in cultivation has lost all or a large portion of its top soil, and a further area of $100,000,000$ acres of crop land is threatened in the future. There is abundant evidence that the problem of soil erosion is one of profound economic importance in many sections of the country. Hundreds of millions of dollars' damage are caused annually through direct depletion or destruction of fields and pastures; the silting of rivers, stream channels, and ditches; damage to highway and railway fills and embankments; 


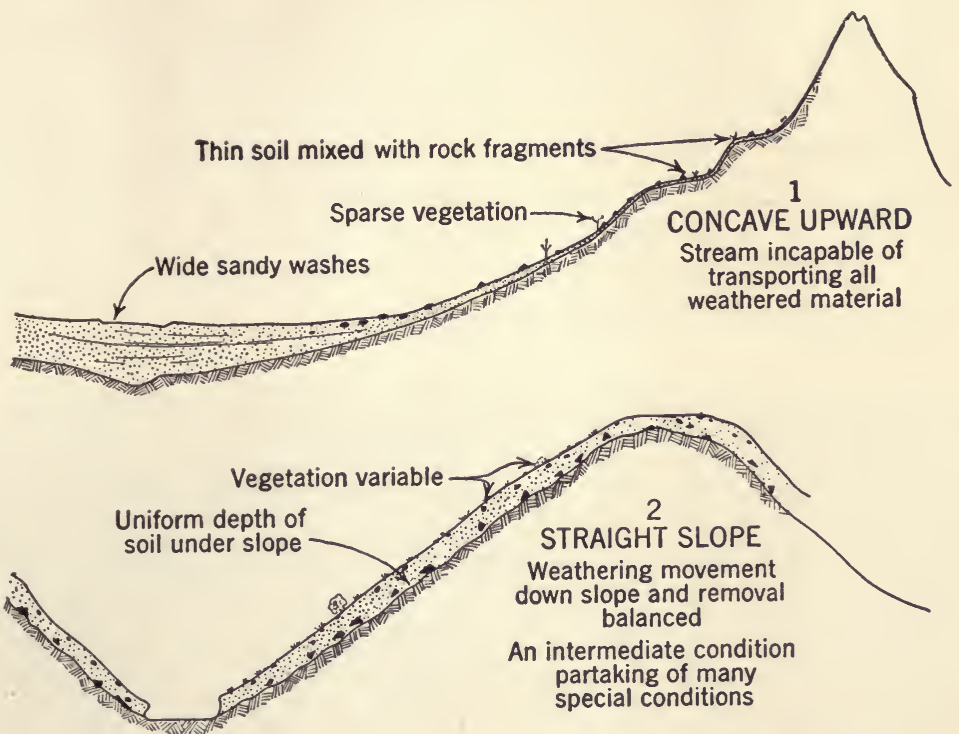

I Distinct Soil Profile

III Little or no surface wash under a complete mantle of vegetation and its litter
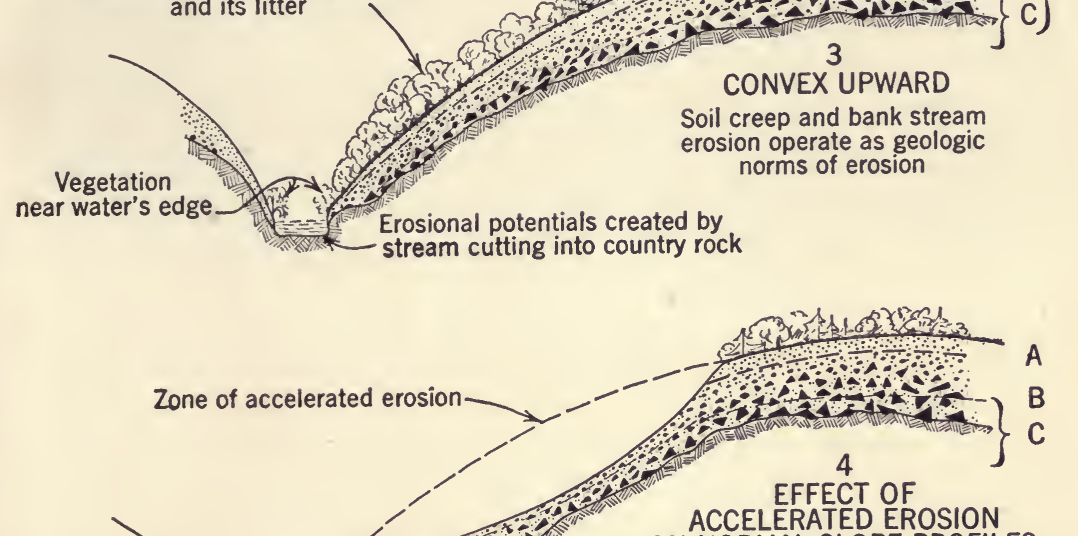

ON NORMAL SLOPE PROFILES

Reversal of processes as result of cultivation on slopes in convex profile topography showing typical convex profiles under vegetation and concave under cultivation

Fig. 127.-Characteristic slope profiles responsive to geological norms of erosion. (After W. C. Lowdermilk.) 
the choking of culverts and smaller bridges; and the covering of valuable valley lands with relatively unproductive erosional débris. The pollution of irrigation, power, and pure water streams with excessive loads of loam and clay washed away from the steeper slopes has resulted in considerable damage to fish life. Enormous quantities of detritus have been washed away from the rich agricultural lands along the lower slopes and valleys.

The accompanying illustration * shows the relation of characteristic slope profiles to the nature of erosion.

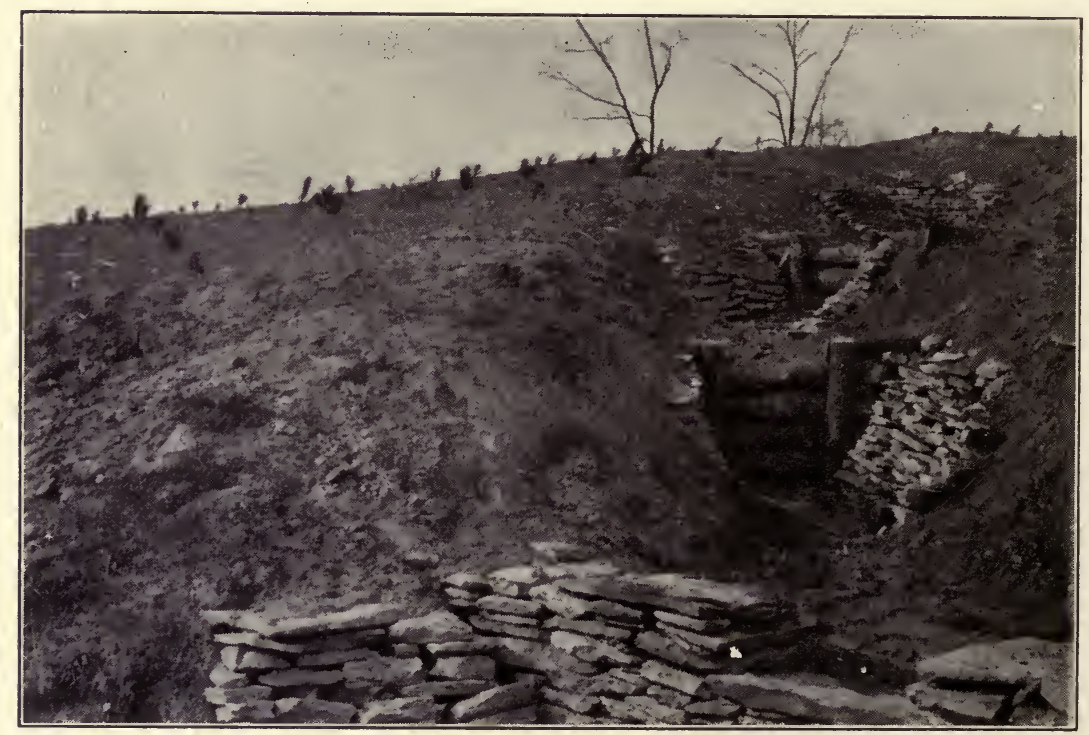

FIG. 128.-Red pine and black locusts planted by Civilian Conservation Corps boys along check dams in Clermont County, Ohio.

Methods of Procedure. The requirements of each type of land, proper consideration being given to soil types, slopes, precipitation, and cover, determine the measures to be applied. It is necessary to coordinate the experience of the forester, the agronomist, the soil specialist, the erosion specialist, and the agricultural engineer, and frequently the game management specialist. It is an established principle of the Soil Conservation Service to enter any affected area only on the invitation of the landowners involved. The procedure is to require $50 \%$ of the owners or more to cooperate and make definite

* From Transactions of the American Geophysical Union's Fifteenth Annual Meeting, 1934, by W. C. Lowdermilk. 
contributions to the work as well as to agree to maintain all structures, dams, plantings, and other improvements for a period of five years.

The principal reliance is upon vegetation as a means of control. There are two general types of erosion by water: (1) sheet erosion, or the general washing away of the soil; (2) gully erosion, which often includes the advanced stages after sheet erosion has washed away the top soil. Wind erosion is still another problem requiring slightly modified control methods.

Two classes of control measures are used in curbing erosion:

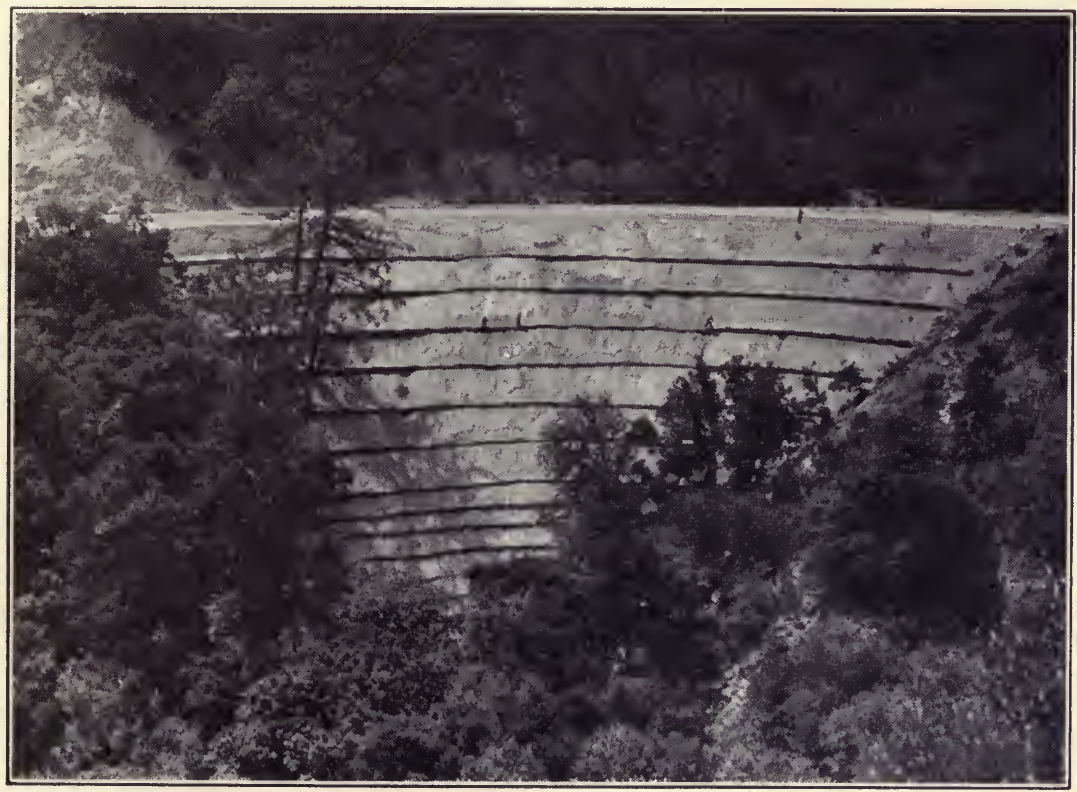

Fia. 129.-An erosion control project along the Angeles Crest Highway in Southern California. Boys of the CCC camps are planting shrubs and other plants to prevent the soil from washing away during and after heavy rains.

vegetative methods, such as the planting of grasses, trees, and shrubs; (2) mechanical methods, such as dams of various types or terracing.

Under the Service an attempt is made to control arroyos in the West by means of diversion dikes and dams to spread the available water over the upland plains in order to increase the growth of grass, trees, and other types of vegetation.

The principal species of trees used in the vegetative control work are black locust, willows, cottonwood, various species of pine, including white, red, shortleaf, and slash and Russian olive and caragana. 
The last two are used chiefly in the West. Also many types of grasses, herbaceous plants, and shrubs serve for this purpose.

In the Wisconsin project, for example, some of the steep timbered areas, now eroding because of excessive grazing, will be taken out of use and given complete protection in order to stop the excessive runoff of rainwater, which has been speeding down across the cultivated slopes, ripping them to pieces or planing off the more fertile topsoil. Pastures will be established on certain areas too erosive for field crops, that furnish feed for quail and ruffed grouse. Eventually, sportsmen are expected to come from Milwaukee, St. Paul, Chicago,

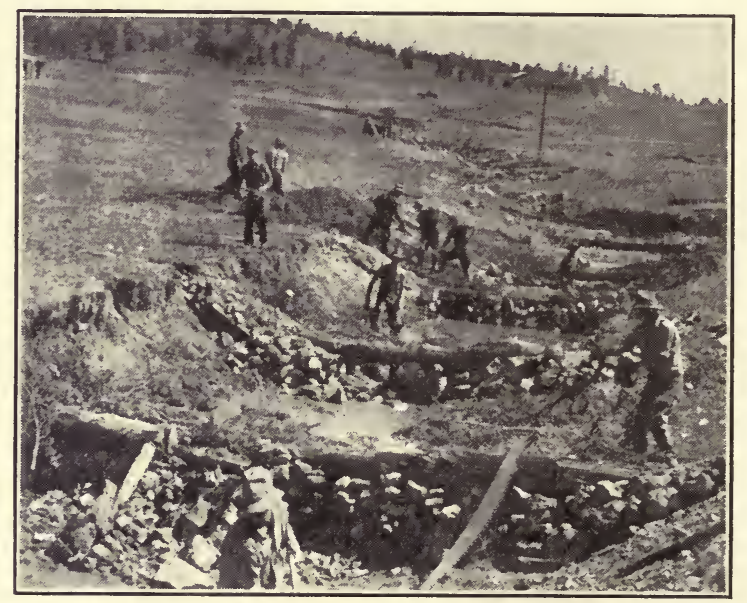

Fig. 130.-Construction of erosion control dams by the use of rocks, timbers and brush near the summit of Trout Creek Pass, Cochetopa National Forest, Colorado. Havoc wrought by cloudbursts is being repaired and further damage prevented.

and other places to pay the farmer for the privilege of hunting in his timbered lands that will be restocked with game. Below the forested land, those steep slopes now washing rapidly to a condition of low productivity will be taken out of clean-tilled crops and put into permanent pasture to furnish the grazing that formerly was supposed to have been provided by the timbered areas.

The general method employed by the Soil Conservation Service in checking erosion is to put the slopes too steep or otherwise unfit for practical farming into trees and the lower slopes into leguminous plants, grasses, and other types of vegetation which possess soil-holding qualities.. Waste lands and those seriously eroded which are unsuitable for cultivation or pasture are planted to trees such as black 
Soll Erosion Control Projects of Soll Conservation Service Department of Agriculture

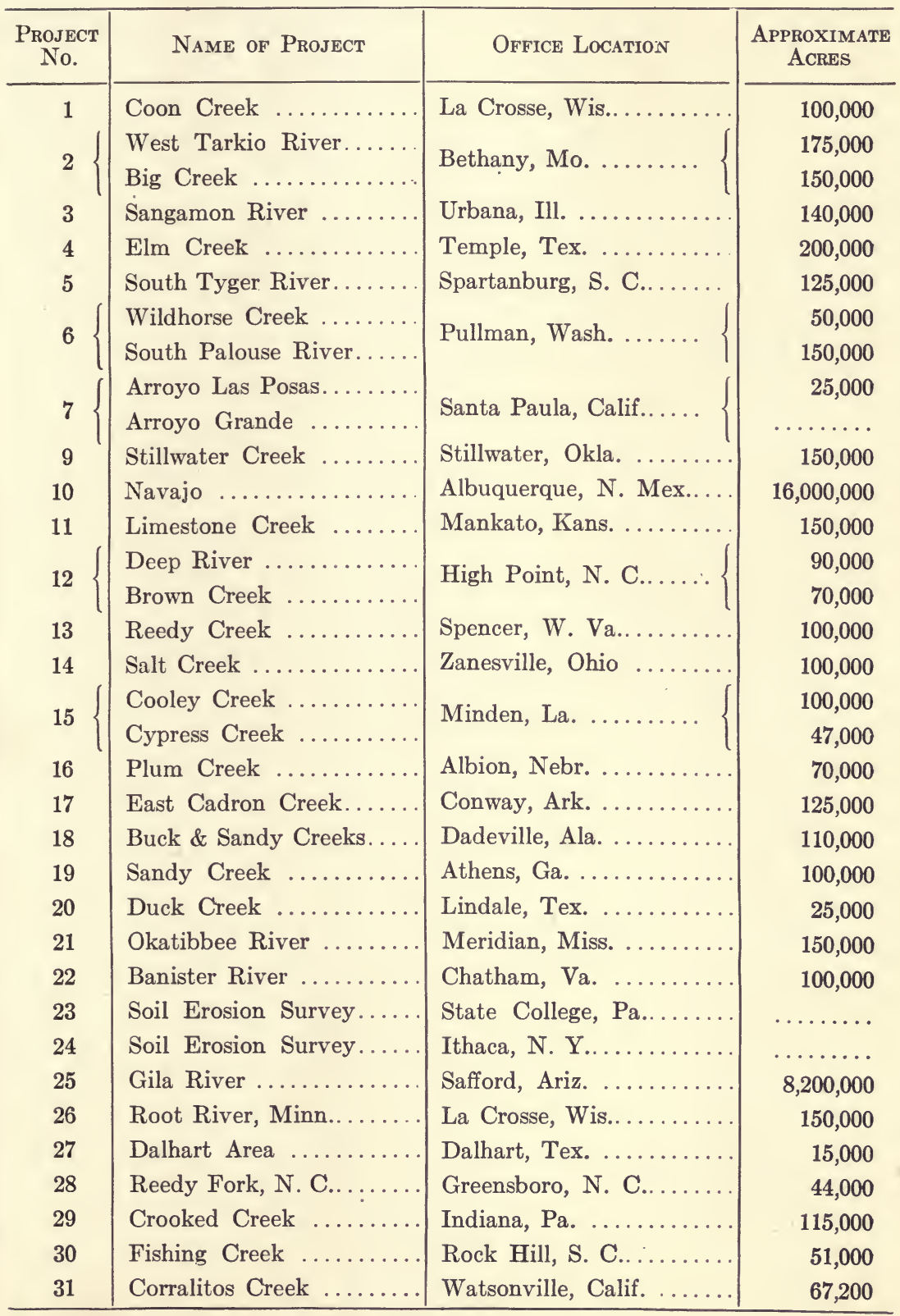


locust and shortleaf pine in the lower Central States, the South, and Southeast. There is little difficulty with erosion in the forested areas that are not over-grazed or seriously burned, particularly where the forest litter has not been destroyed by surface fires. Where gullies have reached the advanced stages, check dams of various forms must be constructed. The edges of gullies are leveled off, and grass and trees are planted to prevent further washing. Usually the successful control of erosion, particularly of gullies, consists of an application and coordination of all these measures. Terracing alone is not sufficient to check soil erosion. Although terracing may be a very useful instrument in some phases of this work it is generally found that a combination of all methods must be pursued in order to obtain satisfactory results. 


\section{CHAPTER XXV}

\section{THE PLAINS SHELTERBELT PROJECT}

President Roosevelt announced this project as a drought-relief measure in June, 1934, and it was started by the Government on July 21. Headquarters were established at Lincoln, Nebraska, and the work is under the U. S. Forest Service. The first plantings were made about the middle of March, 1935, in Texas, Oklahoma, and Kansas. Planting started in Nebraska, early in April and was continued northward as the spring season advanced. The long-continued and very serious drought of 1934, following a most severe winter season, caused intense suffering among the people and enormous losses of crops and cattle throughout the Great Plains region. A state director has been appointed for each state with headquarters at Manhattan, Kansas; Bottineau, North Dakota; Oklahoma City, Oklahoma; Brookings, South Dakota; Lincoln, Nebraska; and Wichita Falls, Texas.

Objectives. The principal objective of this project is to establish and maintain shelterbelts in a zone about 100 miles wide, extending from Canada to the Panhandle of Texas along the eastern margin of the Great Plains region. A shelterbelt is a dense plantation of trees about 100 to 165 feet wide and of various lengths located to provide the maximum protection from prevailing winds. Relief is to be furnished the people of this region by the employment of residents who otherwise have little, if any, cash incomes, and the disbursement of necessary funds for the purchase or lease of lands and supplies. The shelterbelts will provide windbreaks, snowtraps, sandtraps, and shade in a region where trees are generally absent. The trees will mitigate the effects of future drought by preventing quick drying and subsequent blowing of soils. They will protect growing crops from excessive drying and may modify the extremes of temperature as trees and all forms of plant life cool the atmosphere during the growing season. The living conditions for man, beast, bird, and vegetation will be improved. Altogether, the project should be beneficial to the region in which the planting is done.

The people who settled the prairies fully understood the value of trees. They came from parts of the country in which trees grew 
naturally and where the benefits of forest growth had become a matter of everyday life. They had a keen appreciation of the changes that could be effected by tree planting, and in typical pioneer fashion they proceeded to produce groves, windbreaks, shelterbelts and shady woodlands.

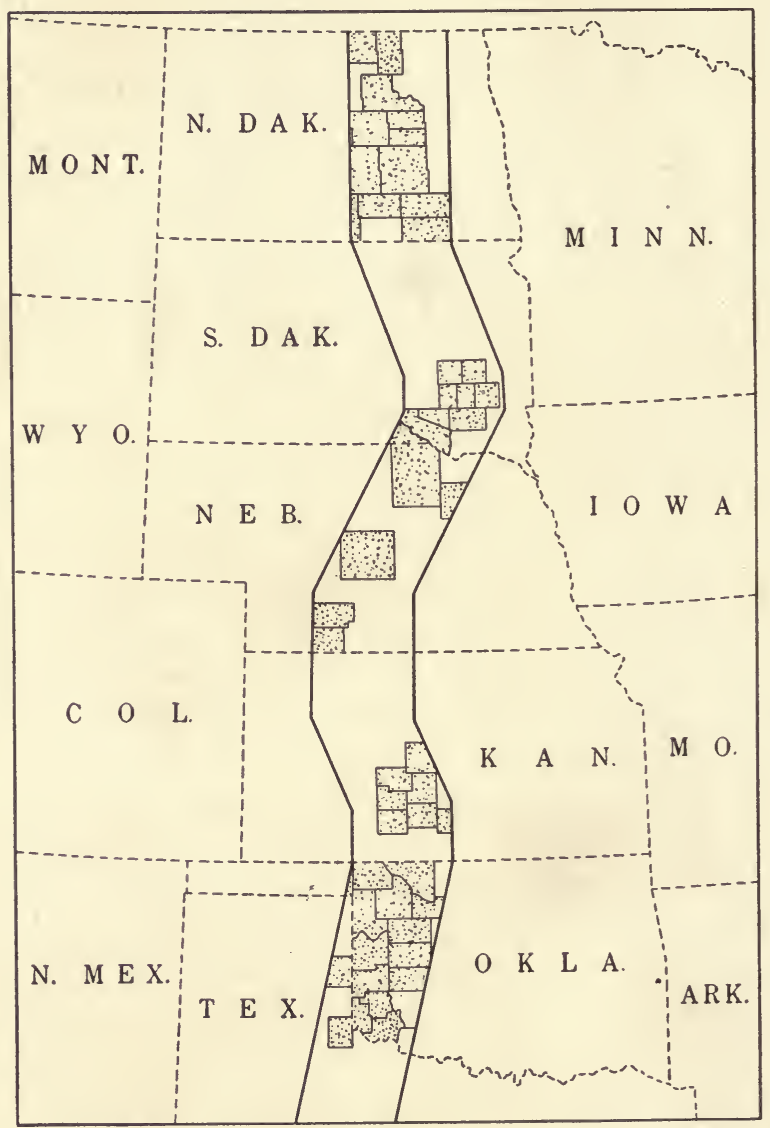

FIG. 131.-Location of Shelterbelt project. Dotted areas were selected for first plantings.

Shelterbelt planting has been conducted during a period of 50 years or more, stimulated largely through the passage of the Timber Culture Act of 1873. There are already estimated to be 2 million acres of shelterbelts planted in the Dakotas, eastern Montana, eastern Colorado, Oklahoma, Nebraska, Kansas, and Texas since 1873.

No forest program has so seized the popular sympathy or appealed so strongly, especially in the prairie plains states, as the present pro- 
posal to create shelterbelts there. It has been conclusively demonstrated that trees can be successfully grown in the plains region where the available annual rainfall does not fall below 18 inches and in some sandy soils where the precipitation is as low as 15 inches per annum.

The function of the shelterbelt project is to produce trees in the relatively treeless Middle West to reduce the destructive effects of wind. It is believed that this will result in conserving moisture, and will stabilize the productiveness of the land, develop game and recrea-

\section{CROSS SECTION OF TYPICAL SHELTER BELT ON TEN ROD STRIP}
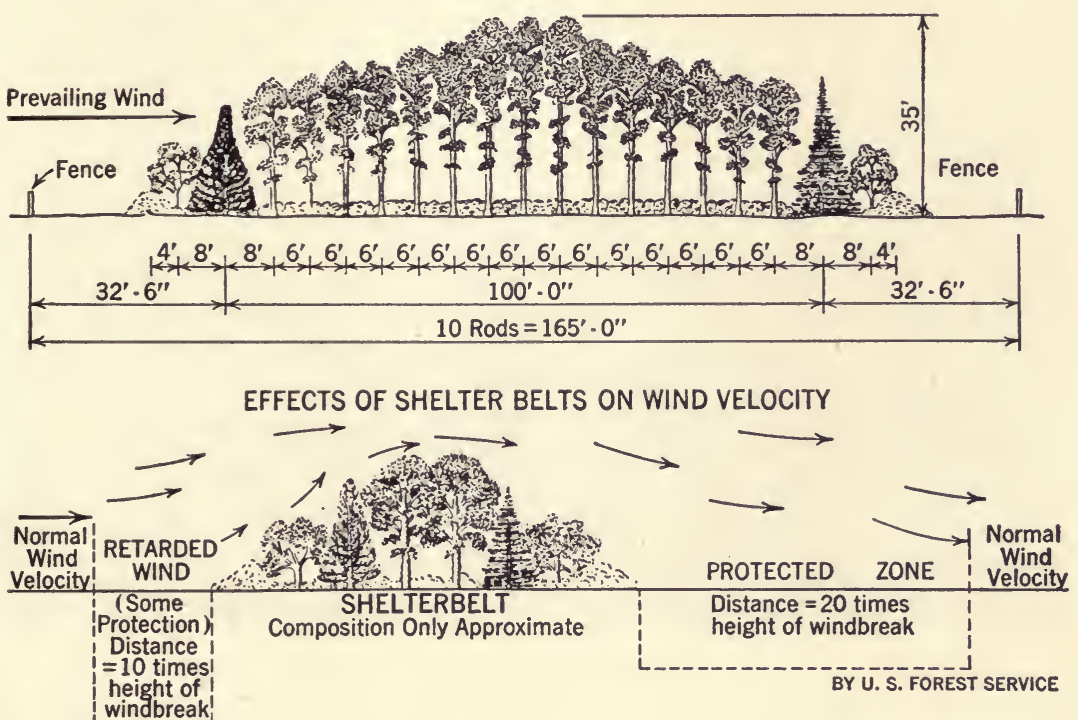

FIG. 132.-Diagram showing cross section of typical shelterbelt and effects of shelterbelts on wind velocity.

tional resources, and make the countryside a much better place in which to live. The purpose is not to withdraw any considerable areas from agriculture and change it to a forest region, but to make a part of it more habitable and more valuable for agriculture through tree planting. Trees will therefore be planted on farm land rather than on range land.

Acquisition and Control of Land. Stability of land tenure is necessary for a project of such permanency and size. The project is based on the premise that the Government shall own or control all lands on which trees are planted. Under private control trees are seldom given 
the protection and cultivation that may be necessary to insure satisfactory development and extended life. The entire plan is based upon a general public improvement and not a subsidy or a dole to some of the residents of the region. The land will be purchased in fee simple or controlled through leases purchased by rights or through cooperative agreements.

General Location of the Shelterbelt Zone. Shelterbelts are planted at intervals of about 1 mile and consist usually of 10 to 20 rows of trees. Nearly every possible variation in form, direction, and

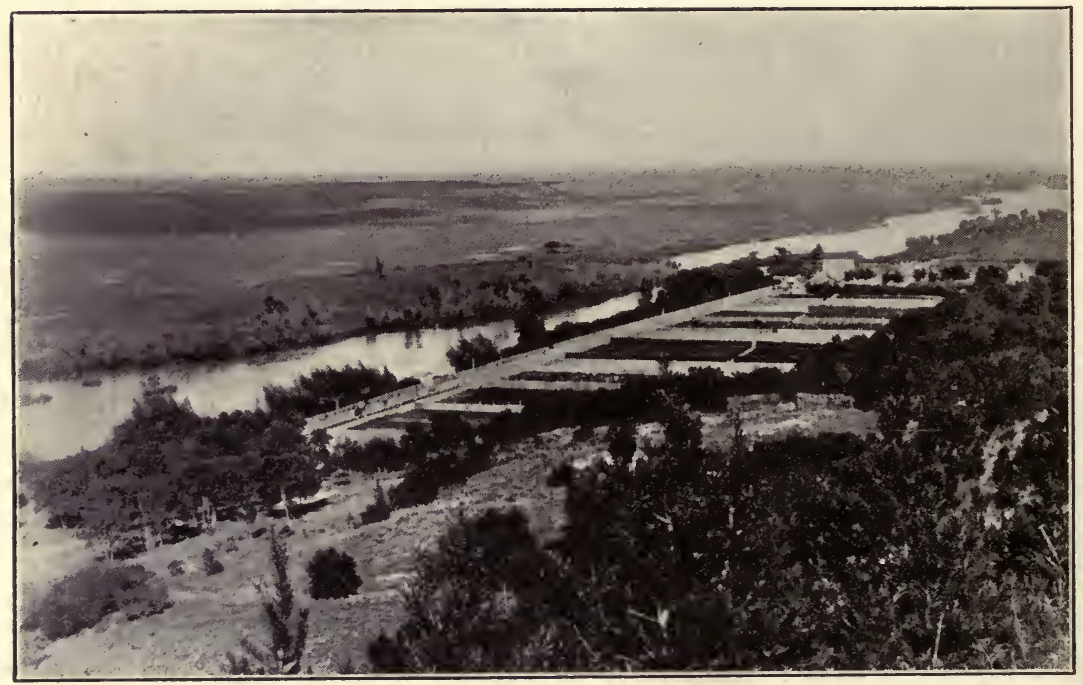

Fig. 133.-Bessey Nursery, Nebraska National Forest, Nebraska, along the Niobrara river. Successful plantations of 13,000 acres of ponderosa pine, jack pine and several other species have been made over a period of several years from these extensive Federal nurseries which have an annual capacity of 2,500,000 trees. About 1200 acres are planted annually on these sand hills.

arrangement will be used, depending upon the location of the prevailing winds and other local circumstances such as topography, soil, and the needs of the local farmsteads. Careful studies of soil, climate, and vegetative factors during the early stages of the project have been made to determine location. They will extend from the northern boundary of North Dakota in a general southerly direction for a distance of about 1000 miles. The eastern boundary generally coincides with the western limit of a region where previous experience gives some reasonable assurance of future success in tree planting. Starting at the northwest corner of Rolette County, North Dakota, the zone 
extends south approximately along the 100th meridian to a point near the southwest corner of McIntosh County on the south line of North Dakota, thence southeast to Ganvalley on the 99th meridian, then straight south to a point south of North Platte, Nebraska, thence to the northwest corner of Gove County, Kansas, thence southeast to Dodge City, Kansas, and to the northwest corner of Harper County, Oklahoma, and southwest to the southwest corner of Scurry County, Texas.

In general, the location is designed to provide the most benefits from tree planting. The area is reasonably productive but subject

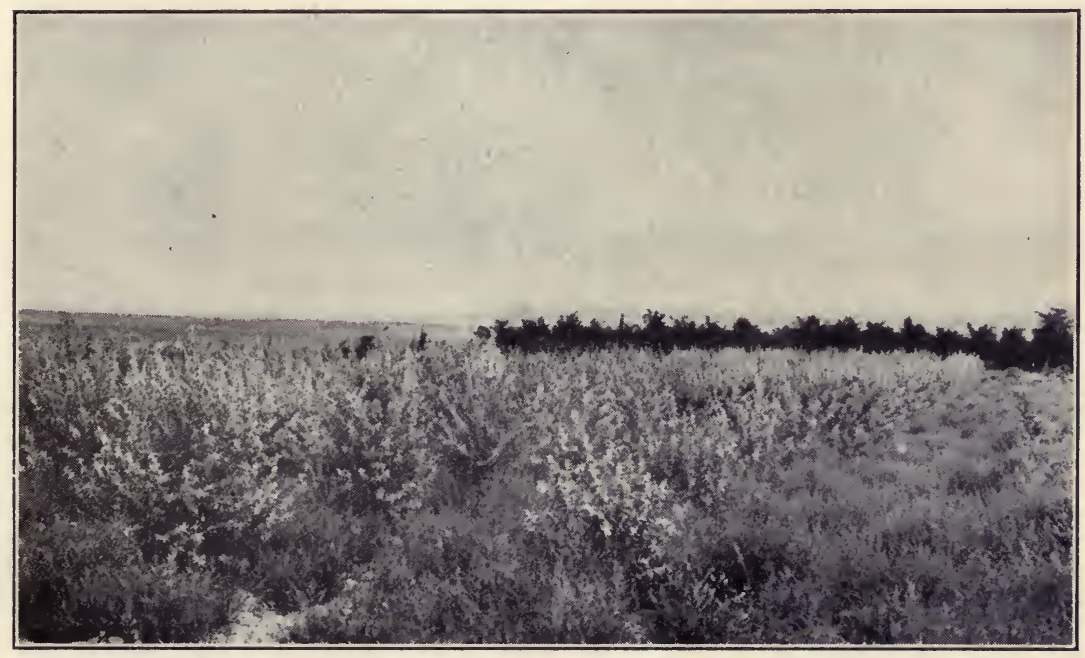

Fia. 134.-One year's successful growth of Russian olive planted near Dalhart, Texas.

to intermittent droughts. Climatic records show that droughts similar to the one of 1934 are of periodic recurrence. Records indicate a recurrence of more abundant precipitation. If the shelterbelts can be established during a period of normal precipitation, it is likely that they will be able to withstand future droughts and perhaps ameliorate their dangerous effects. Some existing plantations which antedate the serious drought of 1890 are the basis for this planting.

Within a zone approximately 100 miles wide and 1000 miles long, trees will be planted on approximately one-fortieth of the area. Agriculture is not to be crowded out. Generally, planting will assume the form of strips 8 to 10 rods wide through the central portion of each section of land consisting of about 16 to 20 acres out of each square 
mile of 640 acres. The width of shelterbelts will be at least 100 feet if the planting is to be effective. A strip 8 rods or 132 feet wide will be obtained by purchase or lease from the landowner and fenced against stock of all kinds, the extra space being needed for extension of roads and the overhanging branches of trees. Roadways will extend inside the fences, and sandtraps will be used to protect the young trees.

Planting strips will not always follow the same direction or plan. Shelterbelts may also be planted along section lines where they will not interfere with road development. A straight-line planting gives protection in only one direction. In the northern part of the zone, protection will be maintained from the northwesterly winds which blow constantly during the winter and early spring. In the south, however, south winds are much more prevalent, frequent, and destructive, and east-west belts will be established in that section.

General Planting Arrangements and Trees to be Used. Trees are planted close together in order to shade out grass and other sun-loving plants. They are not planted, however, so close as to make cultivation in the early years of development difficult.

The cost of fencing will be very large. Experience has indicated that when shelterbelts or tree groves are open to stock, they quickly deteriorate, owing to injuries, grazing, etc. The fencing of the shelterbelts and the preparation of the ground prior to planting are the largest sources of local employment. Many farmers are employed for this work. Many variations from the general straight-line planting are used, such as small clumps or groups of trees to furnish needed shade for stock in pastures, larger groves or blocks where picnic grounds or semi-parks are in demand and where the character of the surface and topography indicate a need for protection from soil erosion. The primary purpose, however, is to furnish protection from wind to the largest possible areas. This will promote the conservation of the soil and will produce other economic benefits. Shelter and food will be provided for many types of game and insectivorous birds as well as other forms of animal life.

The three principal requirements of the shelterbelt are sufficient height, length, and density. The tallest growing trees are placed in the center of the shelterbelts, and closely planted adjoining trees will force them to attain the maximum height growth. The shorter growing trees will be used along the sides, and shrubby growth on the edges. This shape, similar to a hip roof, will tend to guide surface wind currents upward. Evergreens can be used near the edges; retaining their branches near the ground they give greater assurance for the upward sweep of the winds and provide protection during both winter 
and summer. Altogether, however, the deciduous or hardwood trees appear better adapted to the plains conditions than evergreens, with the exception of red cedar and ponderosa pine. Thus the mass effect of tall and sheltering trees and shrubs with a combination of evergreens and deciduous trees will create an effective and dense barrier against the winds. Openings in the shelterbelts will be left for roads, cattle lanes, and other local purposes.

Before planting, the ground is plowed and fallowed for at least one summer to accumulate moisture. Deep penetration of the moisture

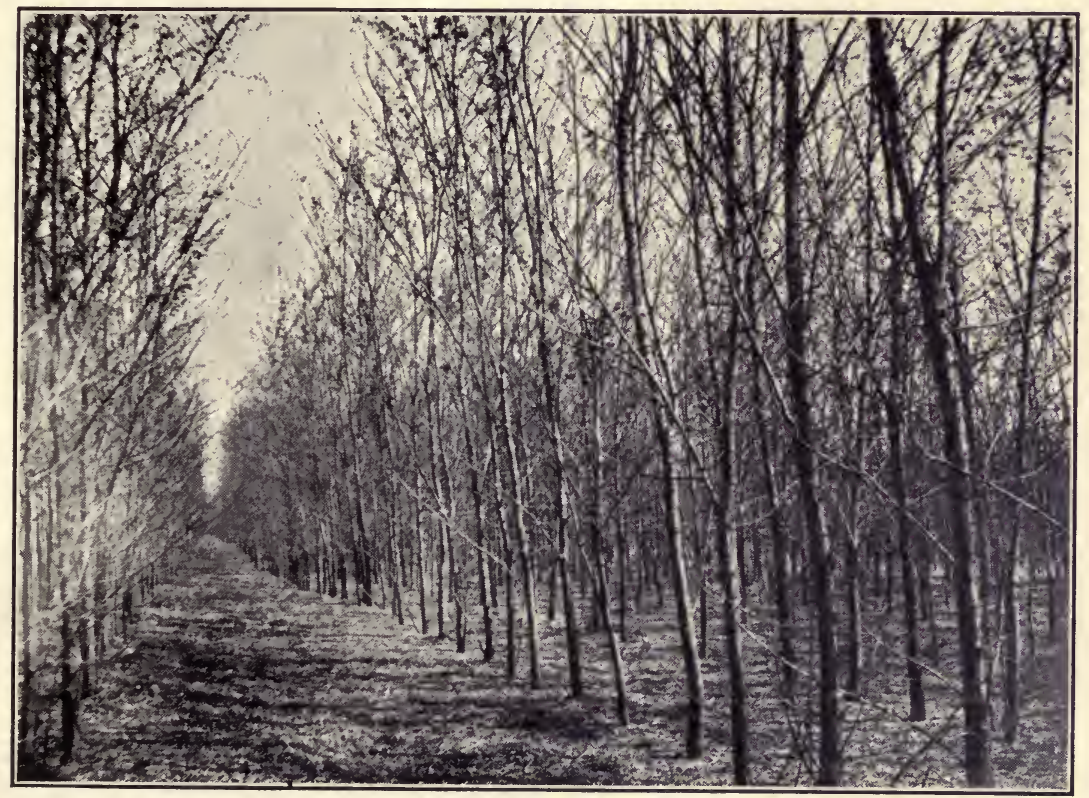

Fig. 135.-Black locust plantation five years old, spaced $4 \times 6$ feet, near Medicine Lodge, Nebraska.

is desirable if deep-rooted trees are to be used. This will be obtained by impounding by means of pits, side ditches, contour listing, and other measures in connection with ground preparation and cultivation as a means of sure survival and to encourage maximum height growth. Thus, moisture conservation is one of the major factors considered in planting and especially with shelterbelts. Weed growth will be discouraged by cultivation for several years after planting or until the trees shade the ground sufficiently to suppress such growth. Later the mulch provided by the leaf litter will serve the purpose of moisture conservation in the soil. 
Great care has been exercised in the selection of trees to be used. The drought of 1934 and the survival of trees have furnished an excellent guide in determining the best trees to be used. Therefore rapidly growing trees or those easy to plant or handle in the nursery are not given first consideration. Altogether native trees of the western region that have become adjusted to the climatic and soil conditions through many years will be the favored species. The list varies from north to south, although red cedar is found naturally throughout the entire range and is the outstanding tree as a survivor of droughts. Green ash has proved to be very successful, although it is attacked in the South by borers and will be used sparingly, unless these pests can be controlled. Elm has proved to be a very satisfactory tree. Chinese elm is one of the foreign species which is believed to have great possibilities. In the southern portion of the region, honey locust is the outstanding hardwood. Black locust is a vigorous and hardy tree in the South, but because of borers its extensive use is considered hazardous. Cottonwood is used on the moister situations throughout the range. Hackberry is also encountered throughout the range and can be used with safety in mixed plantations. Ponderosa pine and jack pine have proved successful in the Nebraska National Forest along the Niobrara River in northern Nebraska. Extensive plantations made by the Forest Service for the past several decades as well as many shelterbelts made by farmers and railroads throughout this region furnish excellent guides for the species to be favored. Ponderosa pine has already proved its drought resistance, and although slow growing, is an excellent tree.

Among other species are Russian olive, caragana, bur oak, chokecherry, plum, hawthorn, willows on moist sites, black or Texan walnut, Russian mulberry, Austrian pine, osage orange, Chinaberry, Chinese arborvitae, Arizona cypress, and pecan. The last four species are used only in Texas and Oklahoma. Blue spruce and the first named species in this group are best adapted to the north and central portions of the shelterbelt range.

Special emphasis is given to the collection of seed within the range and the latitudinal zones in which the trees will be planted.

It is planned to grow and plant, beginning in 1936, about 200 million trees annually in this thousand-mile protective zone, and all available facilities will be utilized. Government nurseries will be installed as needed at key locations where favorable soil and moisture conditions are available. Contracts are to be made with existing commercial nurseries for growing the little trees used in planting. Thus the nursery plans will be divided between organizations and facilities 
already established but will include additional governmental nurseries, using all the trained personnel wherever available. Many state foresters and their staffs and private nurserymen have acquired a great deal of valuable experience during the past 30 years or more in growing and planting trees in this region. This experience will be fully utilized to obtain the most efficient and prompt results.

Trees are generally grown in nurseries for one to two years. Many of the hardwoods develop large root systems and are sufficiently grown to transplant from the nurseries to the shelterbelt at the end of one year. Large trees will not be used because of the expense of transporting from the nursery to the field and the difficulty of survival.

Assuming that the program will consist of a maximum of 100,000 miles of shelterbelt plantings, the following statistics are of interest: The length will be approximately 1000 miles from Canada to the Red River section in Texas; the width will be approximately 100 miles with the western limit at approximately 18 inches of average annual precipitation. The gross area of the zone is about 100,000 square miles or 64 million acres. The shelterbelt strips will be 8 rods or 132 feet wide or, when fenced, 10 rods or 165 feet wide. The direction of the individual shelterbelt strips will be determined by the prevailing winds. The total planting area will be approximately $1,600,000$ acres, or 16 acres per square mile; when fenced, the total area will include about 2 million acres, or 20 acres per square mile.

There will generally be 4 rows of shrubs and 17 rows of trees, making 1732 plants per acre. Thus a total of about 3 billion trees and shrubs will ultimately be planted. The distance between the rows of trees will be 6 and 8 feet, with shrubs 4 feet. The distance between the trees in rows will be 4 feet.

It is estimated that there will be 212,500 miles of fences. Fenceposts placed 20 feet apart will mean $56,100,000$ posts. About 60,000 carloads of material will be required, and 16 million man-days will be needed to consummate the work.

These computations are based upon the maximum possible requirements. Adjustments as appear advisable by local conditions will probably result in some revisions. 


\section{CHAPTER XXVI}

\section{THE PUBLIC DOMAIN GRAZING ADMINISTRATION}

\section{(DIVISION OF GRAZING CONTROL)}

The Taylor Grazing Act passed by Congress in 1934 provided for the establishment of grazing districts on the public domain by the Secretary of the Interior. This is an important conservation measure and marks a distinct forward step in a program of conservation that in the life of our nation may well rival such other conservation measures as the forest, reclamation, and mineral resources measures. The term "public domain" is applied to the unappropriated and unreserved portion of the land still owned by the Federal Government in the socalled public land states. This vast public domain of 165 million acres lies chiefly in 10 far western states and occupies an area as large as the State of Texas. Approximately $95 \%$ of this area lies within what may be approximately termed the 15-inch annual rainfall region embracing the great intermountain basins lying between the Rocky Mountains on the east and the Sierra Nevada and Cascade ranges on the west, together with parts of the northern plains areas of Montana and Wyoming. The intermountain region embraces the great desert ranges of the West which with the exception of relatively small isolated farming communities is public domain. Some portions of it are broken up with grazing or dry farming homesteads, or by state-owned tracts, such as sections 6 and 36 in each township which have been given to the states as school sections by the Federal Government. For many miles on each side of certain of the transcontinental railroad systems the public domain land often lies in alternate sections with railroad land.

In order to carry out the administrative functions of this law, the Secretary of the Interior established a Division of Grazing. This Division will perform the technical function of determining methods and practices of management necessary to rehabilitate the depleted range lands. It will determine the proper number of livestock and period of use that may be properly allowed. It will undertake range improvements such as water development, rodent and predatory ani- 
mal control, eradication of poisonous plants, and other activities that will serve to render the land not only more useful today but of maximum benefit to future American citizens. The program envisages

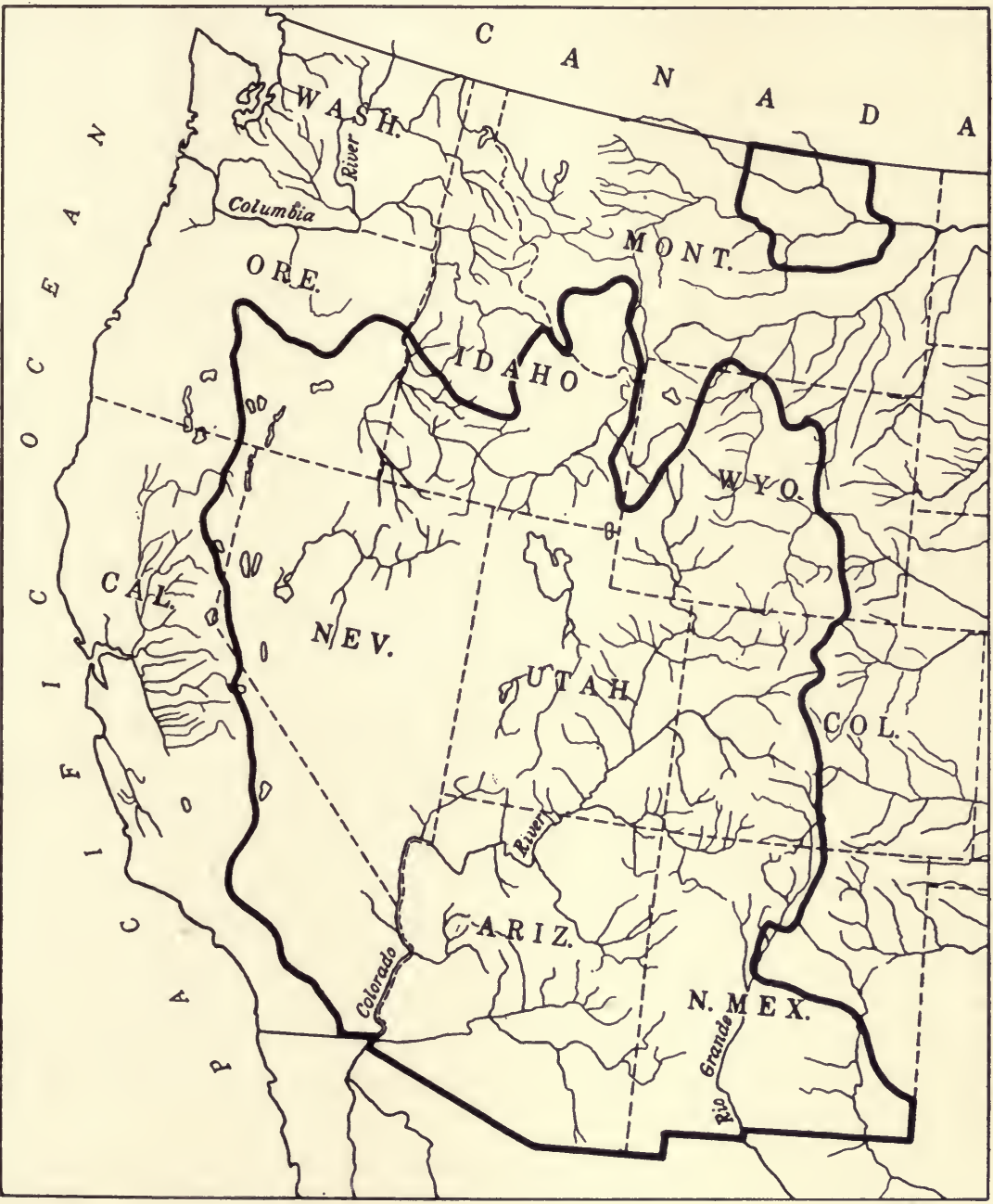

FIG. 136.-Outline of the principal Public domain area shown in heavy type in the Rocky Mountain and Intermountain regions of the West.

the accomplishment of these purposes through a system of cooperation with advisory boards of local stockmen that will aid in the program by furnishing invaluable information of the practical problems involved in the new undertaking. 
Heretofore no governmental agency or organization has been charged with the administration of the public domain. It is estimated by the Division of Grazing that approximately $120,000,000$ acres is usable grazing land. Substantially none is valuable for farming. Conflicts between cattle men and sheep men as well as between ranchers and homesteaders have been frequent and somtimes serious. Because of the checkerboard pattern of most of the public and privately owned grazing land in the western states it has not been usual for ranchers to fence their private holdings except in the more settled portions. A law prohibits the fencing of the public domain. Most of the public range has been seriously over-grazed; in some sections the pasture has been totally destroyed and erosion is gullying the land. Settled communities are generally very uncommon in this great area of grazing lands.

There is some timber found on portions of the public domain, particularly at the higher elevations and mountainous sections of the western states. As noted elsewhere, there are reported to be 22 million acres of wholly or partially timbered lands still unappropriated or unreserved within the public domain.

Under the Taylor Grazing Act the Secretary of the Interior is authorized to provide for the protection, administration, regulation, and improvement of the grazing districts and to enter into cooperative agreements to insure the proper use of them. Grazing permits are to be issued to future users. Fifty per cent of the receipts from grazing fees under the Taylor Act is to be returned to the states in which the grazing district is located, 25 per cent is retained in the U. S. Treasury and 25 per cent is authorized to be appropriated by Congress for range improvements. Authority is granted to continue research in erosion and flood control and to carry on activities for the protection and rehabilitation of the grazing districts under the Secretary of the Interior. No land is being opened to homestead entries unless classified as more valuable for the production of agricultural crops than for forage plants.

The Taylor Act provides constructive administration and the rehabilitation of the most neglected portions of the public land holdings in the West. There has been some local sentiment in the western states in favor of turning over the public domain to the individual states. The general national sentiment, however, has been against this. 


\section{CHAPTER XXVII}

\section{FORESTRY, LAND USE, AND NATIONAL PLANNING}

Within recent years many conferences have been assembled and many committees and individuals have met to discuss the subject of land use in connection with local, regional, state-wide, and national planning. Frequently these discussions have revolved around the contraction in areas devoted to agriculture and the expansion of forest areas, and how best to handle this problem. Articles and publications have been issued freely on the subject.

Planning consists of a systematic, continuous, and forward-looking application of the best facts and information available to programs affecting our individual and national welfare. In many states east of the Mississippi River, considerable land has been released from agricultural production or been permitted to become waste or abandoned land.

In April, 1934, President Franklin D. Roosevelt called the heads of several governmental agencies dealing in land and land use to confer with him and the Cabinet about the formation of a national plan for land use. This resulted in the creation of the National Resources Board, headed by Frederick A. Delano. The board appointed a series of technical committees, one each for land, water, minerals, power, industry, and transportation.

The President instructed the board to prepare and submit by December 1, 1934, a complete and detailed plan for a national land use policy. This report* set forth several considerations which are important in devising plans for national planning, as follows:

1. The necessity and value of coordination of our national and local policies instead of allowing them to drift apart or pull against each other, with disastrous effect.

2. The value of forethought in national life, rather than afterthought-the value of preventing fires rather than putting them out.

* See "A Report on National Planning and Public Works in Relation to Natural Resources," by National Resources Board, Washington, D. C., December 1,1934 . 
3. The value of the best plan for the most competent collection and analysis of facts.

Many community, county, regional, and state-wide planning boards have been created during the past several years as a result of this widespread interest in planning. Their activities center largely around forest policies and plans for more and better forests and parks. In 1931, the National Land Use Planning Committee was informally established by the U. S. Secretary of Agriculture. Sentiment has no

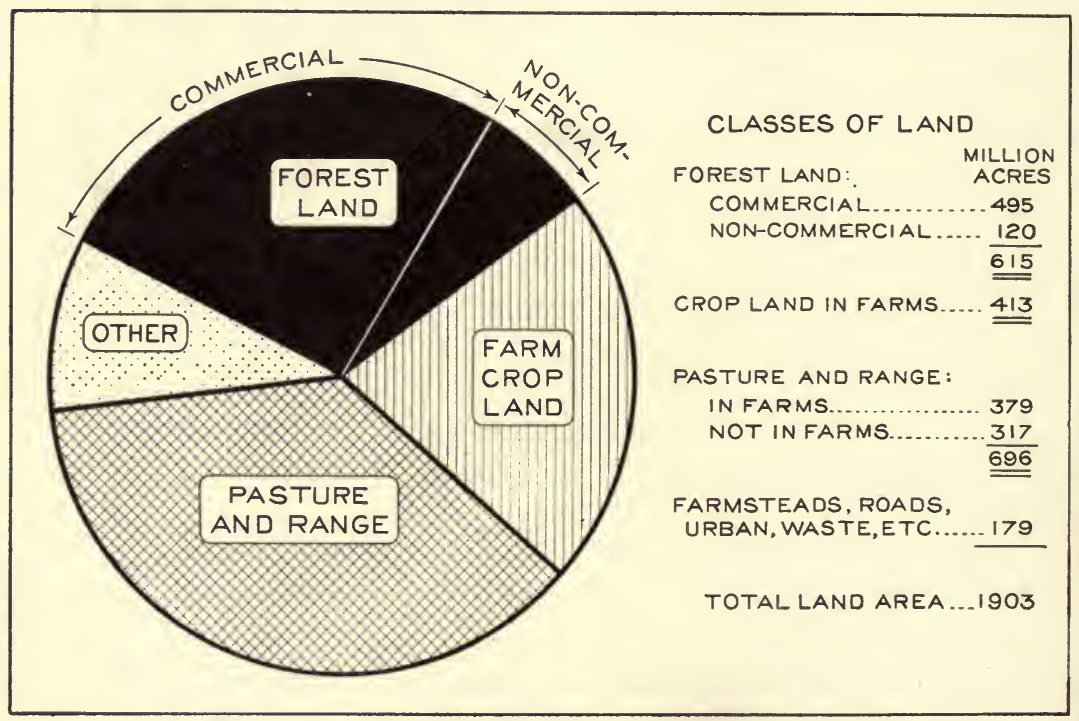

Fig. 137.-Classes of land and their present use in the United States.

doubt been crystallized in the direction of increased acquisition of public forests by federal, state, and county authorities. In nearly every state, a state-wide planning board has been created to study problems of forestry and forest conservation, water resources, farmland abandonment, development of agriculture, the present and prospective use of power facilities, highways including railroads, and canals, in relation to transportation problems, population trends, and many others. Their studies have given forest conservation a new meaning and significance. Prior to this recent movement, Wisconsin, Illinois, Kentucky, Maryland, New Jersey, Virginia, and Washington created permanent planning commissions by legislative authority.

Planning does not involve the regimentation of private enterprise or private lives. It does not necessarily include adherence to a fixed 
or unchangeable system or plan of action. It does, however, involve a re-examination of trends, tendencies, and policies, so that our state and federal governmental programs may be better coordinated with the ultimate aim better to provide for the happiness and welfare of future generations.

Any sound land policy should be designed to make our resources contribute the greatest possible permanent good to the national wel-

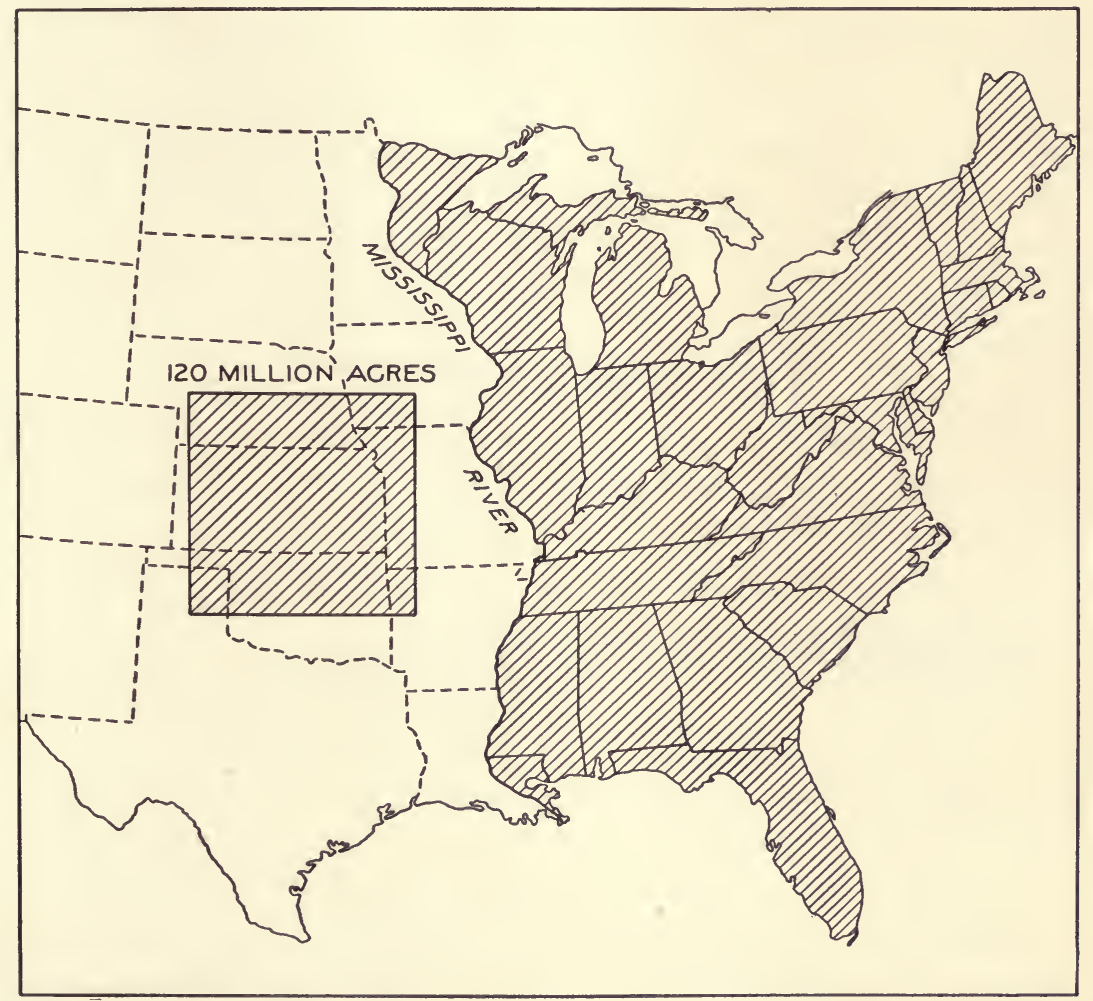

Fig. 138.-Our forests, if concentrated together, would cover all lands east of the Mississippi River with 120 million acres additional.

fare. It should put the various types of land into uses for which they are best suited and into the production of commodities and services needed in our communities. It should provide not only for present wise use but also for continued use by future generations. Land use management may assume the form of land zoning, which means the classification of lands with respect to the best uses from both the public and private viewpoints. 
The undertaking by our forest industries to establish a system of commercial forestry on privately owned lands should be successfully supported by federal and state governments. The latter should provide adequate fire prevention, equitable systems of taxation, advanced plans of forest management, protection against insects, diseases, and other injuries, and the general encouragement of sustained yield plans.

The rate of population growth in the United States is slowing down perceptibly. Statisticians estimate that the maximum population will probably be reached about the year 1960 and will not be more than $150,000,000$ people. After 1960, population is likely to decline. Northern European countries likewise face stationary or declining populations. Any plan of land use must properly contemplate the per capita consumption of lumber and other forest products as well as the use of our forests for the multiple purposes described elsewhere in the text. The per capita consumption of lumber has dropped from 510 b.f. in 1907 to 275 b.f. in 1929, 150 b.f. in 1931, and 95 b.f. in 1932.

The problem of land use planning has probably become most acute in the older settled sections of the Northeast, the South, and the Lake States. There are the following classifications of present land use in the United States according to the U. S. Forest Service:

1. Forest land, including commercial, non-commercial, and

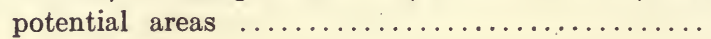

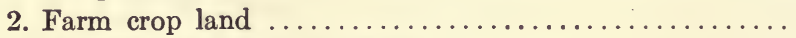

3. Pasture and range in farms $\ldots \ldots \ldots \ldots \ldots \ldots \ldots \ldots$

4. Pasture and range not in farms chiefly in the western

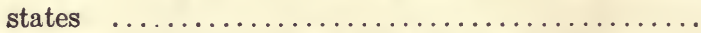

5. Urban development including roadside areas, etc. .....

Total

ACRES

$615,000,000$

$413,000,000$

$379,000,000$

$317,000,000$

$179,000,000$

$1,903,000,000$

The original forest areas of the United States were about 820,000,000 acres. About one-fourth of the original forest area has been converted into crop, pasture, and grazing areas. But of that onefourth, some 52,000,000 acres are now available through abandonment or for other reasons for growing trees. The U. S. Forest Service estimated that probably $25,000,000$ to $30,000,000$ additional acres may be available by 1950 .

The Forest Service has advocated a large-scale plan of acquisition of forests. The so-called Copeland Report of March, 1933, advocated additional public forests amounting to $224,000,000$ acres, of which $90,000,000$ should be acquired by the states and $134,000,000$ by the Federal Government. Of the latter, 22,000,000 acres are already 
in the public domain and the remaining $112,000,000$ would be acquired by purchase as follows:

$1,500,000$ in New England.

$1,500,000$ in the Middle Atlantic States.

$11,000,000$ in the Lake States.

$15,000,000$ in the South.

$5,000,000$ in the West.

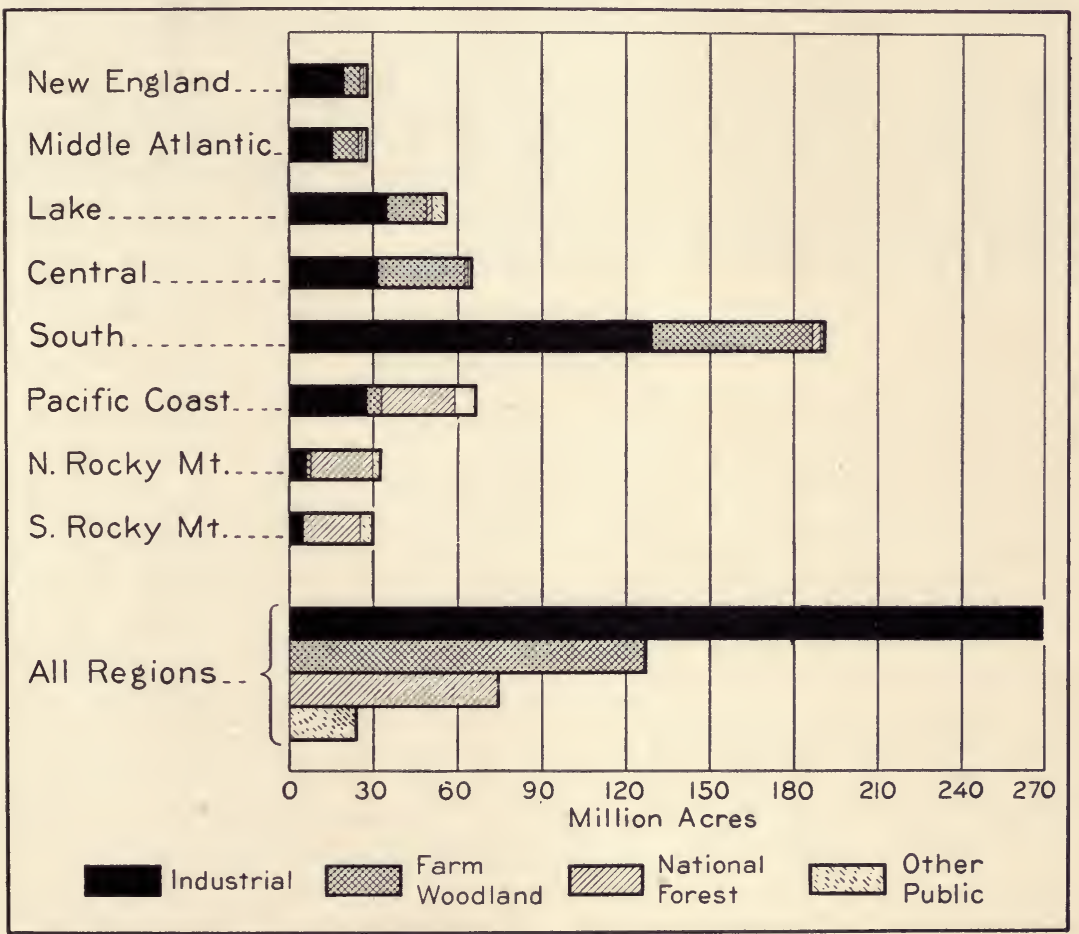

Fra. 139.-Ownership of forest lands by regions.

This program is roughly estimated to cost $\$ 500,000,000$ for the Federal Government and $\$ 250,000,000$ for the states, to be allocated over a period of 20 years.

Of the 52,000,000 acres of agricultural land now available through abandonment or otherwise, for forests, $31,000,000$ acres are included in this program of public forest acquisition.

Many authorities believe that both the Federal Government and the states should acquire considerable additional areas. However, it is also widely held that our forests should not be owned almost ex- 
clusively by the public agencies. The high mountain areas should be owned, protected, controlled, and operated by the public agencies, especially at the headwaters of streams, where the chief function is to protect the watersheds from fire and where the forest will probably never attain great commercial importance. The better lands and smaller holdings, such as the farmers' woodlots, tracts of land on which timber may be quickly grown to supply the industries in our more settled communities, should be left to private ownership. In several states there has been some opposition to government ownership of National Forests, notably in Georgia and Maryland. The federal and state governments should own and control the forests where it is not possible for private individuals or corporations to make forestry a commercial success because of the long time required to grow a crop of trees, the physical and financial hazards involved, and the generally poorer locations of publicly owned forests. 


\section{APPENDIX}

\section{SELECTED BIBLIOGRAPHY, AND REFERENCES FOR MORE EXTENDED READING}

These are in addition to the numerous government publications available at low cost from the U. S. Forest Service, National Park Service, and several other governmental agencies, as well as State Forest Services and several schools of forestry. Many of these organizations have lists of publications available for distribution at low cost or free of charge.

\section{GENERAL FORESTRY}

"A National Plan for American Forestry." Senate Document 12, Washington, D. C., 1933.

Crumley, J. J. "Constructive Forestry for the Private Owner." New York, Macmillan Co., 1926.

Ferguson, John Arden. "Farm Forestry." New York, John Wiley \& Sons, 1916. "Forestry Almanac." American Tree Association, Washington, D. C., 1933.

GrLl, T. H. "Tropical Forests of the Caribbean." Washington, D. C., Tropical Plant Research Foundation, 1931.

Graves, H. S., and Guise, C. H. "Forest Education." New Haven, Yale University Press, 1932.

Hiley, W. E. "The Economics of Forestry." Oxford, England, Clarendon Press, 1930.

ILlick, J. S. "Outline of General Forestry." New York, Barnes and Noble, 1935.

Moon, F. F., and Brown, Nelson C. "Elements of Forestry." Second edition. New York, John Wiley \& Sons, 1929.

Pack, Arthur Newton. "Our Vanishing Forests." New York, Macmillan Co., 1923.

Pack, Arthur Newton. "Forestry, An Economic Challenge." New York, Macmillan Co., 1933.

Pack, Charles Lathrop. "Forestry Primer." Washington, D. C., American Tree Assoc., 1935.

Pack, Charles Lathrop, and Gill, Tom. "Forests and Mankind." New York, Macmillan Co., 1929.

Pack, Charles Lathrop, and Gill, Tom. "Forest Facts for Schools." New York, Macmillan Co., 1931.

PerRY, G. S. "Forestry in Sweden." Mt. Alto, Pa., published by the author, 1929.

Recknagel, A. B., and Spring, S. N. "Forestry." New York, A. A. Knopf, 1929.

"Terms Used in Forestry and Logging." Washington, D. C., Government Printing Office, 1905.

Zon, R., and Sparhawk, W. N. "Forest Resources of the World," vols. 1-2. New York, McGraw-Hill Book Co., 1923. 


\section{FOREST INVESTIGATIONS}

Bailey, I. W., and Spoehr, H. A. "The Role of Research in the Development of Forestry in North America." New York, Macmillan Co., 1929.

Bates, C. G., and Zon, R. "Research Methods in the Study of Forest Environment." Washington, D. C., 1922. U.S.D.A. Bulletin 1059.

Clapp, E. H. "A National Program of Forest Research." Washington, D. C., American Tree Association, 1926.

ZoN, R. "Forests and Water in the Light of Scientific Investigation." Washington, D. C., Forest Service, 1927.

\section{FOREST MENSURATION}

Belyea, H. C. "Forest Measurement." New York, John Wiley \& Sons, 1931.

Bruce, D., and Schumacher, F. X. "Forest Mensuration." New York, McGrawHill Book Co., 1935.

Cary, A. "Woodsman's Manual." Cambridge, Harvard University Press, 1932.

Chapman, H. H., and Demerritt, D. B. "Elements of Forest Mensuration," Albany, N. Y., J. B. Lyon Co., 1932.

Winkenwerder, H., and Clark, E. T. "Handbook of Field and Office Problems in Forest Mensuration." New York, John Wiley \& Sons, 1922.

\section{SILVICULTURE AND MANAGEMENT}

BAKer, F. S. "Theory and Practice of Silviculture." New York, McGraw-Hill Book Co., 1935.

Chapman, H. H. "Forest Finance." New Haven, Conn., Tuttle, Morehouse and Taylor, 1926.

Chapman, H. H. "Forest Management." Albany, N. Y., J. B. Lyon Co., 1931.

Eldpredge, I. F. "Management Plans, with Special Reference to the National Forests." Washington, D. C., 1928. U.S.D.A. Misc. Publication 11.

Hawley, R. C. "The Practice of Silviculture." Third edition. New York, John Wiley \& Sons, 1935.

Hiley, W. E. "Improvement of Woodlands." London, Country Life, Ltd., 1931.

Leopold, A. "Game Management." New York, Scribner, 1933.

Matrhews, D. M. "Management of American Forests." New York, McGrawHill Book Co., 1935.

Recknagel, A. B. "Theory and Practice of Working Plans." New York, John Wiley \& Sons, 1917.

Recknagel, A. B., and Bentley, J. "Forest Management." Second edition. New York, John Wiley \& Sons, 1926.

Sampson, A. W. "Range and Pasture Management." New York, John Wiley \& Sons, 1923.

Toumey, J. W. "Foundations of Silviculture upon an Ecological Basis." New York, John Wiley \& Sons, 1928.

Toumey, J. W., and Korstian, C. F. "Seeding and Planting in the Practice of Forestry." Third edition. New York, John Wiley \& Sons, 1931.

Troup, R. S. "Silvicultural Systems." Oxford, Clarendon Press, 1928.

Troup, R. S. "The Silviculture of Indian Trees." Vols. 1-3. Oxford, Clarendon Press, 1921: 


\section{FOREST PROTECTION}

Felt, E. P. "Manual of Tree and Shrub Insects." New York, Macmillan Co., 1924.

Graham, S. A. "Principles of Forest Entomology." New York, McGraw-Hill Book Co., 1929.

Hubert, E. E. "An Outline of Forest Pathology." New York, John Wiley \& Sons, 1931.

Pierson, H. B. "Manual of Forest Insects." Augusta, Maine, 1927. Maine Forest Commission Bulletin 5.

Snow, S. B., and Коток, E. I. "Role of Fire in Pine Forests of California." Washington, D. C., 1925. U.S.D.A. Bulletin 1294.

\section{FOREST POLICY AND ADMINISTRATION}

Boerker, R. H. D. "Our National Forests." New York, Macmillan Co., 1918. TAYLOR, J. L. B. "Handbook for Rangers and Woodsmen." New York, John Wiley \& Sons, 1917.

Woolsey, T. S., JR. "Studies in French Forestry." New York, John Wiley \& Sons, 1920.

\section{FOREST UTILIZATION}

Brown, Nelson C. "Logging-Principles and Practices in the United States and Canada." New York, John Wiley \& Sons, 1934.

Brown, Nelson C. "Forest Products, Their Manufacture and Use." Second edition. New York, John Wiley \& Sons, 1927.

'Brown, Neison C. "The American Lumber Industry." New York, John Wiley \& Sons, 1923.

Bryant, R. C. "Logging." Second edition. New York, John Wiley \& Sons, 1923.

Bryant, R. C. "Lumber: Its Manufacture and Distribution." New York, John Wiley \& Sons, 1922.

Grbbons, W. H. "Logging in the Douglas Fir Region." Washington, D. C., 1918. U.S.D.A. Bulletin 711.

Hawley, L. F., and Wise, L. E. "The Chemistry of Wood." New York, Chemical Catalog Co., 1926.

Hawley, L. F. "Wood Distillation." New York, Chemical Catalog Co., 1923.

Hayward, P. A. "Wood, Lumber and Timbers." New York, W. L. Chandler, 1930.

Kellogg, R. S., and Sмiтh, F. H. "Lumber and Its Uses." Fourth edition. New York, Scientific Book Corporation, 1931.

KellogG, R. S. "Pulpwood and Wood Pulp in North America." New York, McGraw-Hill Book Co., 1923.

KLAR, M. "Technology of Wood Distillation." London, Chapman \& Hall, 1925. Koenler, A., and Thelen, R. "The Kiln Drying of Lumber." New York, McGraw-Hill Book Co., 1926.

Schorger, A. W. "The Chemistry of Cellulose and Wood." New York, McGrawHill Book Co., 1926. 


\section{WOOD TECHNOLOGY AND DENDROLOGY}

Bailey, L. H. "The Cultivated Conifers." New York, Macmillan Co., 1934.

Brown, H. P., and Panshin, A. J. "Identification of the Commercial Timbers of the United States." New York, McGraw-Hill Book Co., 1934.

Garretr, G. "The Mechanical Properties of Wood." New York, John Wiley \& Sons, 1931.

Harlow, W. M. "Twig Key to the Deciduous Woody Plants of the Eastern United States." Second edition. Syracuse, N. Y. New York State College of Forestry, 1935.

Harlow, W. M. "Trees of the United States," Part I, Hardwoods; Part II, Softwoods. Third edition. Ann Arbor, Mich., Edwards Bros., 1934.

Hough, R. B. "Handbook of the Trees of the Northern States and Canada." Lowville, N. Y., published by the author, 1907.

RECoRD, S. J. "Identification of Timbers of Temperate North America." New York, John Wiley \& Sons, 1934.

RECoRD, S. J., and Mell, C. D. "Timbers of Tropical America." New Haven, Yale Univ. Press, 1924.

Sargent, C. S. "Manual of the Trees of North America." Second edition. Boston, Houghton Mifflin \& Co., 1926.

\section{PERIODICALS}

The following contain much valuable current information on forestry:

Forestry News Digest, American Tree Association, 1214-16th St., Washington, D. C.

American Forests, published monthly by the American Forestry Association, 1713 K St., Washington, D. C.

Journal of Forestry, published monthly by the Society of American Foresters, Hill Bldg., Washington, D. C.

American Lumberman, published bi-monthly, 431 S. Dearborn St., Chicago, Ill. Southern Lumberman, published bi-monthly, Presbyterian Bldg., Nashville, Tenn. Timberman, Spalding Bldg., Portland, Oregon.

West Coast Lumberman, published monthly, at 71 Columbia Bldg., Seattle, Wash. Nature Magazine, published monthly by American Nature Assoc., 1214 - 16th St.,

Washington, D. C.

\section{THE NATIONAL INDUSTRIAL RECOVERY ACT,* THE LUMBER CODE AND FORESTRY}

The most significant, noteworthy advance in the progress of private or industrial forestry in the United States was the establishment of the lumber code and

* This act was declared unconstitutional by the U. S. Supreme Court on May 27, 1935. This brief description is appended because of historical interest and the fact that many private owners of timber properties have voluntarily continued to observe the conservation features of the code. On June 19, 1935, the directors of the National Lumber Manufacturers Association urged members of the lumber industry to continue the progress made in forest conservation under the code. 
its provision "to conserve forest resources and bring about the sustained production thereof."

The National Industrial Recovery Act was adopted in 1933, and the Forest Industries Code was approved by President Roosevelt on August 19, 1933. Article $\mathrm{X}$ of this Code provided for the conservation and sustained production of forest resources on the forest operations of all persons under the jurisdiction of the lumber code. Potentially, this affected 250 million acres of land owned by the lumber, industrial, and timber holding companies, and the 125 million acres of farm timberland which are commercially utilized. The lumber code was one of the first to be accepted and put into effect under this act.

The importance of putting privately owned forest properties under a systematic plan of forest management is at once recognized, when it is realized that practically four-fifths of our total forest area is owned by private corporations and individuals, including farmers. Although an elemental and extensive form of forestry has been extended to our federal forests and parks and to a small area of State Forests and Parks, and a measure of fire protection has been effective upon private forests, relatively little forest management has been practiced on our private forest properties.

The Code of Fair Competition for the lumber and timber products industries stated that it was the declared purpose of those industries and of the adherents to the code to accomplish the following:

1. To reduce and alleviate unemployment in these industries.

2. To improve the standards of labor therein.

3. To maintain a reasonable balance between the production and consumption of lumber and timber products.

4. To restore the prices thereof to levels which would avoid the further depletion and destruction of capital assets.

5. To conserve forest resources and bring about the sustained yield thereof.

There were twenty-one main provisions of the lumber code designed to carry out these declared purposes.

The lumber industry, through its properly delegated representatives and in cooperation with federal and state agencies concerned, established fundamental principles which served as a basis for conservation measures to be required on all privately owned logging operations. The Lumber Code Authority on February 9,1934 , adopted the following objectives for minimum standards for all forest regions as follows:

1. Protection of standing timber and young trees from fire and other destructive forces.

2. Prevention of damage to young trees during and immediately following logging operation.

3. Provision for replanting cleared land after logging, if sufficient advanced growth was not already present.

4. To leave, where feasible, some portion of the virgin timber as basis for growth of the next timber crop.

5. Partial cutting or selective logging to be the general standard of forest practice.

The original rules of woods practice, governing cutting operations for saw logs, became effective June 1, 1934. Compliance with the provisions of improved 
code practice was generally very good, considering the complex and diversified structure of the industry and the newness and vast size of the undertaking.

Forest conservation under the code was intended to be a joint enterprise, following the recommendations of the forestry conferences held in Washington late in 1933 and early in 1934, in conformity with Article X of the lumber code. While industry was to carry forward its own activities, it was expected that the federal Congress would enact a broad legislative program, intended to pave the way for private forest management on an economic basis, by setting up a forest credits system comparable with the Farm Credit Act; that federal aid in fire protection, already granted to private timberland owners under the ClarkeMcNary Act of June 7, 1924, would be extended in scope; that forest research would be broadened and directed at problems vital to forest production.

Organization. Most of the provisions of the lumber code were put into effect through local or regional lumber manufacturers or similar associations, based either on geographical location or similarity of species or product. There were 128 administrative agencies of the various divisions, subdivisions, and groups. For example, of the many subdivisions, the hardwood division had 7, Southern Pine 1, the West Coast Logging and Lumber Division 4, the Woodworking Division 3, Wooden Package Division 8, the Red Cedar Shingle Division 1, the Veneer and Plywood 3, the Cross Arm Division 4, the Pole and Piling 11, and the Cross Tie Division 7.

The governing body or agency responsible for the administration of the lumber code was the Lumber Code Authority, with headquarters in Washington.

Production of forest materials varies widely with each section of the country -from structural timber and construction lumber to poles and piling and railway cross ties, from round-edged box lumber as in New England, to small squares of hardwood dimension from which are manufactured spools, bobbins, and chair rungs.

Article $\mathrm{X}$ of the lumber code sought to assure for all regions a continuous supply of forest products, continuity of operation, stability of employment, and permanence of communities depending upon forests and forest products for employment. This is the very essence of sustained yield forest management. One of the most important functions of the Lumber Code Authority was control of production, based upon expectation of market requirements. By the exercise of this function, it was expected that forest output would be balanced with growth, and that under wise management, promoting greater growth, a larger output would be obtained without impairment of forest capital.

The minimum lumber prices which were in effect shortly after the code was adopted were suspended by the Administration in December, 1934.

Under Schedule C, the Forest Conservation Code and Rules of Forest Practice were put in effect through the following agencies:

1. Northeastern Lumber Manufacturers Association of New York City, including the Northeastern Hardwood Subdivision and the Northeastern Softwood Subdivision.

2. The Northern Hemlock and Hardwood Association of Oshkosh, Wisconsin, including the Northern Hemlock Division and the Northern Hardwood Subdivision.

3. The California Redwood Association of San Francisco, California, including the Redwood Division. 
4. The Western Pine Association of Portland, Oregon, under which was included the Western Pine Division. This Division was the most widely diversified, because it had to do with rules of forest practice on all the Rocky Mountain and Pacific Coast States where ponderosa pine grows. There were 7 districts, designated as follows:
(a) Montana.
(b) Idaho.
(c) Washington.
(d) Oregon.
(e) California.
(f) Arizona-New Mexico.
(g) Rocky Mountains.

The last included Engelmann spruce, lodgepole pine, ponderosa pine and Douglas fir types, whereas the other districts were predominately of ponderosa pine, except in the Idaho district where in the northern part of the state, Idaho white pine type is the most valuable.

5. The Hardwood Manufacturers Institute of Memphis, Tennessee, including the $\Lambda$ ppalachian and Southern Hardwood Subdivisions.

6. The Southern Cypress Manufacturers Association of Jacksonville, Florida, including the Cypress Division.

7. The North Central Hardwood Association of Indianapolis, Indiana, which included the North Central Hardwood Subdivision.

8. The West Coast Lumbermen's Association of Seattle, Washington, which included the West Coast Logging and Lumber Division.

9. The Southern Pine Manufacturers Association of New Orleans, Louisiana, which included the Southern Pine Division.

10. The Northern Pine Manufacturers Association of Minneapolis, Minnesota, which included the Northern Pine Division.

Details of the rules of forest practice were formulated for each of these divisions by its respective conservation agency. For example, in order to insure forest lands being kept continuously productive in the southern pine region, it was specified that 100 trees of 4 to 7 inches in diameter 12 inches above the ground or 10 trees 8 to 11 inches in diameter, or 2 trees 12 inches or larger or equivalent combinations must be left by the operator per acre as a minimum. In longleaf pine forests, the minimum individual to be left was a tree 5 feet or more in height, and 4 trees per acre were required in the 12-inch or larger class. In all the Divisions, in order to promote development of sustained yield forest management as permanent operating policy, all persons who were certified by their division agencies as obtaining their raw materials from lands under their ownership or control that were managed on a sustained yield basis were awarded an additional production allotment of $10 \%$ under Article VIII of the lumber code.

As indicated above, the Rules of Forest Practice varied considerably with each region and had to do with fire protection during and immediately following logging, cooperation and protection against fire, insects, and disease, the conservation of immature trees and young growth during and subsequent to logging, and provision for restocking the land after cutting through selective logging, planting, or other measures. 


\section{COMMON AND BOTANICAL NAMES}

The following is a list of the more important native species of trees found in the United States and Canada.

\begin{tabular}{|c|c|}
\hline \multirow{2}{*}{\multicolumn{2}{|c|}{ СоммоN }} \\
\hline & \\
\hline Ash, blue ....... & Fraxinus quadrangulata \\
\hline Ash, green $\ldots$. & Fraxinus pennsylvanica lanceolata \\
\hline Ash, white ...... & Fraxinus americana \\
\hline Aspen $\ldots \ldots \ldots$ & Populus tremuloides \\
\hline Aspen, largetooth & .Populus grandidentata \\
\hline Basswood ....... & Tilia glabra \\
\hline Beech .. & Fagus grandifolia \\
\hline Birch, gray ...... & . Betula populifolia \\
\hline Birch, paper ... & . Betula papyrifera \\
\hline Birch, sweet .... & .. Betula lenta \\
\hline Birch, yellow ... & . Betula lutea \\
\hline Butternut ....... & .Juglans cinerea \\
\hline Catalpa ......... & . Catalpa speciosa \\
\hline Cedar, Alaska .. & . Chamaecyparis nootkatensis \\
\hline Cedar, incense .. & .. Libocedrus decurrens \\
\hline Cedar, Port Orfor & . Chamaecyparis lawsoniana \\
\hline Cedar, eastern rec & . Juniperus virginiana \\
\hline Cedar, western re & . Thuja plicata \\
\hline Cedar, northern w & . Thuja occidentalis \\
\hline Cedar, southern w & .Chamaecyparis thyoides \\
\hline Cherry, black ... & . Prunus serotina \\
\hline Chestnut $\ldots \ldots$. & Castanea dentata \\
\hline Cottonwood, blacl & Populus trichocarpa \\
\hline Cottonwood, easte & Populus deltoides \\
\hline Cypress, southern & Taxodium distichum \\
\hline Dogwood, flowerir & Cornus florida \\
\hline Douglas fir .... & Pseudotsuga taxifolia \\
\hline Elm, American .. & Ulmus americana \\
\hline Elm, rock ..... & .Ulmus racemosa \\
\hline Fir, alpine ..... & Abies lasiocarpa \\
\hline Fir, balsam ..... & Abies balsamea \\
\hline Fir, corkbark ... & Abies arizonica \\
\hline Fir, lowland whit & Abies grandis \\
\hline Fir, noble ..... & Abies nobilis \\
\hline Fir, red ....... & Abies magnifica \\
\hline Fir, silver ..... & -Abies amabilis \\
\hline Fir, white ..... & Abies concolor \\
\hline Gum, black .... & .Nyssa sylvatica \\
\hline Gum, tupelo .... & . Nyssa aquatica \\
\hline Hackberry ..... & .Celtis occidentalis \\
\hline Hemlock, eastern & Tsuga canadensis \\
\hline Hemlock, western & .Tsuga heterophylla \\
\hline Hickory, bitternu & . Hicoria cordiformis \\
\hline
\end{tabular}


Common Name Botanical Name

Hickory, pignut .............Hicoria glabra

Hickory, shagbark ...........Hicoria ovata

Hickory, water .............Hicoria aquatica

Holly ................... Ilex opaca

Hop-hornbeam ............. Ostrya virginiana

Ironwood, black ............. Rhamnidium ferreum

Larch, western ..............Larix occidentalis

Locust, black ..............Robinia pseudocacia

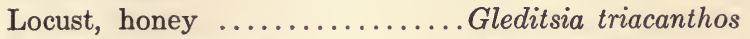

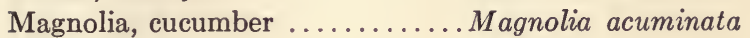

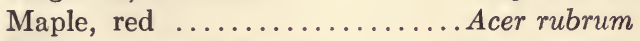

Maple, sugar or hard ..........Acer saccharum

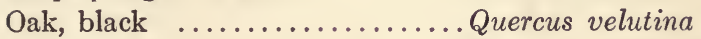

Oak, bur ................... Quercus macrocarpa

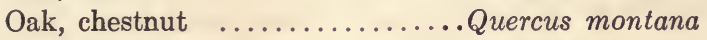

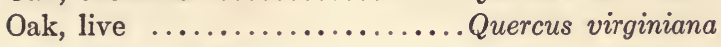

Oak, Oregon white .........Quercus garryana

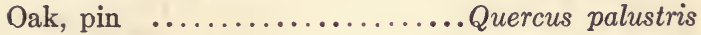

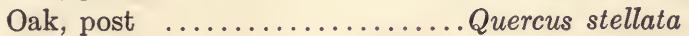

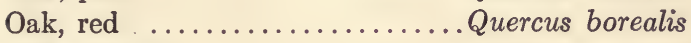

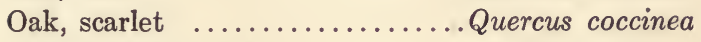

Oak, southern red ............Quercus rubra

Oak, swamp red .............Quercus rubra pagodaefolia

Oak, swamp chestnut .........Quercus prinus

Oak, swamp white ...........Quercus bicolor

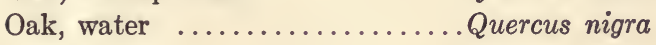

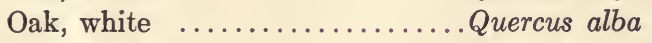

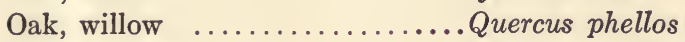

Osage-orange ...............Toxylon pomiferum

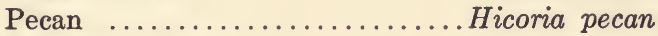

Persimmon ................ Diospyros virginiana

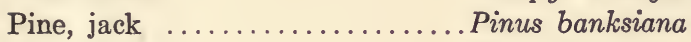

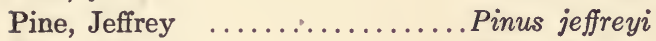

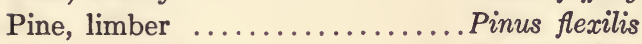

Pine, loblolly ................Pinus taeda

Pine, lodgepole .............Pinus contorta

Pine, longleaf ..............Pinus palustris

Pine, northern or eastern white ..Pinus strobus

Pine, Norway or red ...........Pinus resinosa

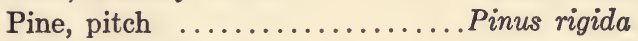

Pine, ponderosa .............Pinus ponderosa

Pine, shortleaf ..............Pinus echinata

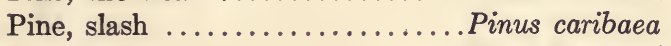

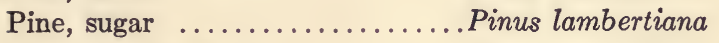

Pine, western white ...........Pinus monticola

Poplar, balsam .............Populus balsamifera

Poplar, yellow ...............Liriodendron tulipifera

Redwood ...................Sequoia sempervirens

Spruce, black ..............Picea mariana 
APPENDIX

Common Name

Botanical Name

Spruce, Engelmann

Picea engelmannï

Spruce, red

. Picea rubra

Spruce, Sitka

Picea sitchensis

Spruce, white

Picea glauca

Sycamore

.Platanus occidentalis

Tamarack

Larix laricina

Walnut, black

Juglans nigra

Willow, black

Salix nigra

Yew, Pacific

. Taxus brevifolia 


\section{INDEX}

Aesthetic values, 12

Allen, S. W., 222

Animal damage, 88

Animals, domestic, 88

wild, 88

Árbor day, 26

Arboriculture, 24

Belyea, H. C., 91

Blister rust, 86

Branches of forestry, 22

Brown, H. P., 160

Bruce and Schumacher, 91

Causes of fires, 73

Chapman, H. H., 91, 228

Civilian Conservation Corps, 241

Clapp, E. H., 234

Clear-cutting methods, 101

Cline, A. C., 101

Collection, seed, 117

Contiol methods, fires, 80

Cooperage, 181

Coppice method, 105

Costs of lumber, 155

Cross ties, 174

Cruising, 94

Cutting, improvement, 131 in National Forests, 107 liberation, 130

Cuttings, intermediate, 128

Day, R. K., 225

Definition of forestry, 1

Depletion, 50

Demeritt and Chapman, 91

Division of Grazing, 272

Dunes, protection against, 89

Dutch elm disease, 87

Dyewoods, 181
Ecology, 61

Eggleston, N., 192

Elm disease, Dutch, 87

Emergency Conservation Work, 241

Employment, 12

Employment trends, 183

European methods, 14

Farm woodland, 223

Fernow, B. E., 32, 192

Fiber boards, 175

Fires, control and suppression, 80 detection, 74

forest, 68

prevention, 75

Forest fires, 68

Forest influences, 61

Forest insects, 83

Forest mensuration, 91

Forest policies, industrial, 167

Forest policy agencies, 189

Forest products, 172

Forest regions, 34

Forest resources, 34

Forest Service, 190

Forest utilization, 135

Forestry, and land use, 275

as a profession, 16

branches of, 22

difficulties of, 225

industrial, 135

private, 221

Forestry agencies, 189

Forestry education, 228

Forestry occupations, 230

Forests, State, 213

town, county, and community, 219

Fuelwood, 177

Fungi, forest, 85

Game in National Forests, 198 
Game management, 197

Garratt, George, 163

Garver, R. D., 149

Graves, H. S., 33, 192, 230, 232

Greeley, W. B., 33, 192

Growth and depletion, 50

Guise, C. H., 230

Hawley, L. F., 163

Hawley, R. C., 63, 99, 130, 233

History and development, 26

Hough, F. B., 30, 32, 192

Industrial forest policies, 167

Industrial forestry, 135

Influence on climate, 13

Influences, forest, 61

Insects, 83

Instruments used, 92

Korstian, C. F., 65, 113

Laws, history of, 30

Leaders in forestry, 32

Legislation, federal, 30

Lockard, C. R., 100

Log rules, 93

Logging, selective, 147

Logging methods, 139

Lowdermilk, W. C., 257

Lumber, costs of producing, 155 principal species cut, 154

Lumber cut, 154

Lumber distribution, 156

Lumber industry, history, 27 importance, 135

Lumber manufacture, 152

Maple syrup and sugar, 182

Measure, units of, 91

Mensuration, forest, 91

Mine timbers, 174

Morton, J. Sterling, 26

Munger, T. T., 100

National Forests, 190 silviculture in, 107

National Park functions, 208

National Park Service, 205

National planning, 275
Naval stores, 179

Nursery practice, 118

Objectives of forestry, 9

Ownership, 39

Pack, A. N., 33

Pack, C. L., 33

Paper, 175

Parks, National, 205

Percentage of trees used, 165

Piling, 174

Pinchot, Gifford, 30, 32, 192, 241

Plains Shelterbelt Project, 263

Planning, national, 275

Planting, 113

Planting wild stock, 127

Plywood, 178

Poles, 174

Policies, state forest, 213

Pratt, George D., 33

Preservation methods, 186

Preservation of timber, 185

Preservative, requirements of, 186

Primitive areas, 198

Private forestry, 221

Products, forest, 172

principal, 50

Professional requirements, 20

Properties of wood, 159

Pruning, 131

Public domain grazing, 272

Public relations, 201

Rayon, 175

Record, S. J., 160

Recreation, 197

Reforestation, 113

spacing, 123

Reproduction, natural, advantages of, 100

Research, 199, 216, 232

Resource frontiers, 29

Roosevelt, Franklin D., 31, 33, 189, 192, 238

Roosevelt, Theodore, 31, 32, 241

Roth, Filibert, 32

Rules, for thinning, 133

$\log , 93$ 
Salaries in forest service, 203

Sand dunes, 89

Sawmill waste, 169

Scaling, 93

Schenck, Carl, 32, 228

Schools of forestry, 228

Seed collection, 117

Seed selection, 117

Seed-tree method, 102

Selection method, 104

Selection of seed, 117

Selective logging, 147

Shelterbelt project, 263

Shelterwood method, 102

Show, S. B., 100

Silcox, F. A., 192

Silvics, 61

Silvicultural systems, 101

Silvicultural treatment, 128

Silviculture, 99

American versus European, 106

artificial reproduction, 113

in National Forests, 107

Soil Conservation Service, 255

Southern fire problem, 82

Spacing used in planting, 123

Species, commercial, 42

used in planting, 123

Stuart, R. Y., 192

Stumpage, 96

Stumpage values, 97

Systems, silvicultural, 101

Tables, volume, 94

yield, 95

Tannins, 181
Taxation, 226

Tennessee Valley Authority, 249

Thinning, 131, 133

Tillamook fire, 72

Tillotson, C. R., 219

Timber preservation, 185

Timber values, 97

Timber volume, 40

Toumey and Korstian, 65, 113

Tree, definition, 53

Tree characteristics, 53

Tree planting, 113

Trees, number per acre, 124

Turpentine operations, 179

Uses of wood, 159

Utilization, factors of, 166

Values, stumpage, 97

Veneers, 178

Volume tables, 94

Waste, sources of, 164

Wild stock, 127

Wise, L. E., 163

Wood construction, advantages, 138

Wood distillation, 181

Wood pulp, 175

Wood uses and economics, 159

Woodland, farm, 223

Woods waste, 165

reducing, 169

Yield tables, 95

Zon, R., 149 









Or.rentawers. 
S. 